\title{
TECHNICAL SUPPORT FOR GEOPRESSURED-GEOTHERMAL WELL ACTIVITIES IN LOUISIANA
}

FINAL REPORT

for the period

1 November 1983 to 31 October 1984

C.G. Groat

Program Coordinator

December 1985

Work Performed under Contract DE-AC08-81NV10174

\footnotetext{
Louisiana State University

Office for Research

Louisiana Geological Survey

University Station, Box G

Baton Rouge, LA 70893
} 


\section{DISCLAIMER}

This report was prepared as an account of work sponsored by an agency of the United States Government. Neither the United States Government nor any agency Thereof, nor any of their employees, makes any warranty, express or implied, or assumes any legal liability or responsibility for the accuracy, completeness, or usefulness of any information, apparatus, product, or process disclosed, or represents that its use would not infringe privately owned rights. Reference herein to any specific commercial product, process, or service by trade name, trademark, manufacturer, or otherwise does not necessarily constitute or imply its endorsement, recommendation, or favoring by the United States Government or any agency thereof. The views and opinions of authors expressed herein do not necessarily state or reflect those of the United States Government or any agency thereof. 


\section{DISCLAIMER}

Portions of this document may be illegible in electronic image products. Images are produced from the best available original document. 


\section{DISCLAIMER}

This report was prepared as an account of work sponsored by the United States Government. Neither the United States nor the United States Department of Energy, nor any of their employees, makes any warranty, express or implied, or assumes any legal liability or responsibility for the accuracy, completeness, or usefulness of any information, apparatus, product, or process disclosed, or represents that its use would not infringe privately owned rights. Reference herein to any specific commercial product, process, or service by trade name, mark, manufacturer, or otherwise, does not necessarily constitute or imply its endorsement, recommendations, or favoring by the United States Government or any agency thereof. The views and opinions of authors expressed herein do not necessarily state or reflect those of the United States Government or any agency thereof.

Printed in the United State of America

Available from:

National Technical Information Service

U.S. Department of Commerce

5285 Port Royal Road

Springfield, Virginia 22161

Price: Printed copy A06

Microfiche AO1 
$\mathrm{DOE} / \mathrm{NV} / 10174-5$

TECHNICAL SUPPORT

FOR

GEOPRESSURED-GEOTHERMAL WELL ACTIVITIES

IN LOUISIANA

FINAL REPORT

for the period

1 November 1983 to 31 October 1984

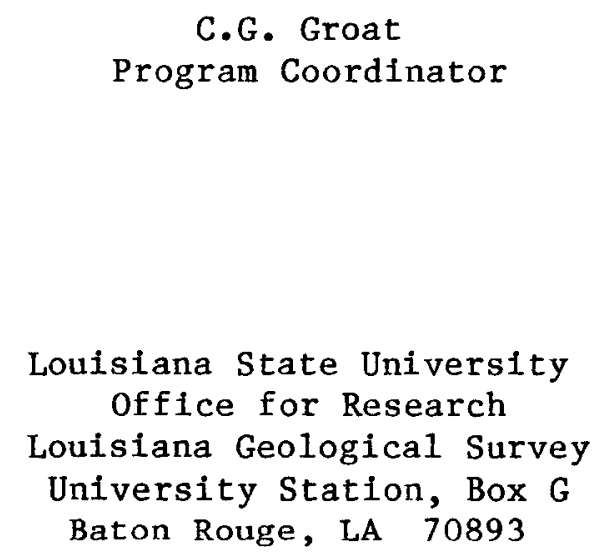

Baton Rouge, LA 70893

\author{
Prepared for the \\ U.S. Department of Energy \\ Division of Geothermal Energy \\ Under Contract DE-AC08-81NV10174
}


$\bullet$

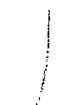

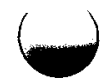




\section{CONTENTS}

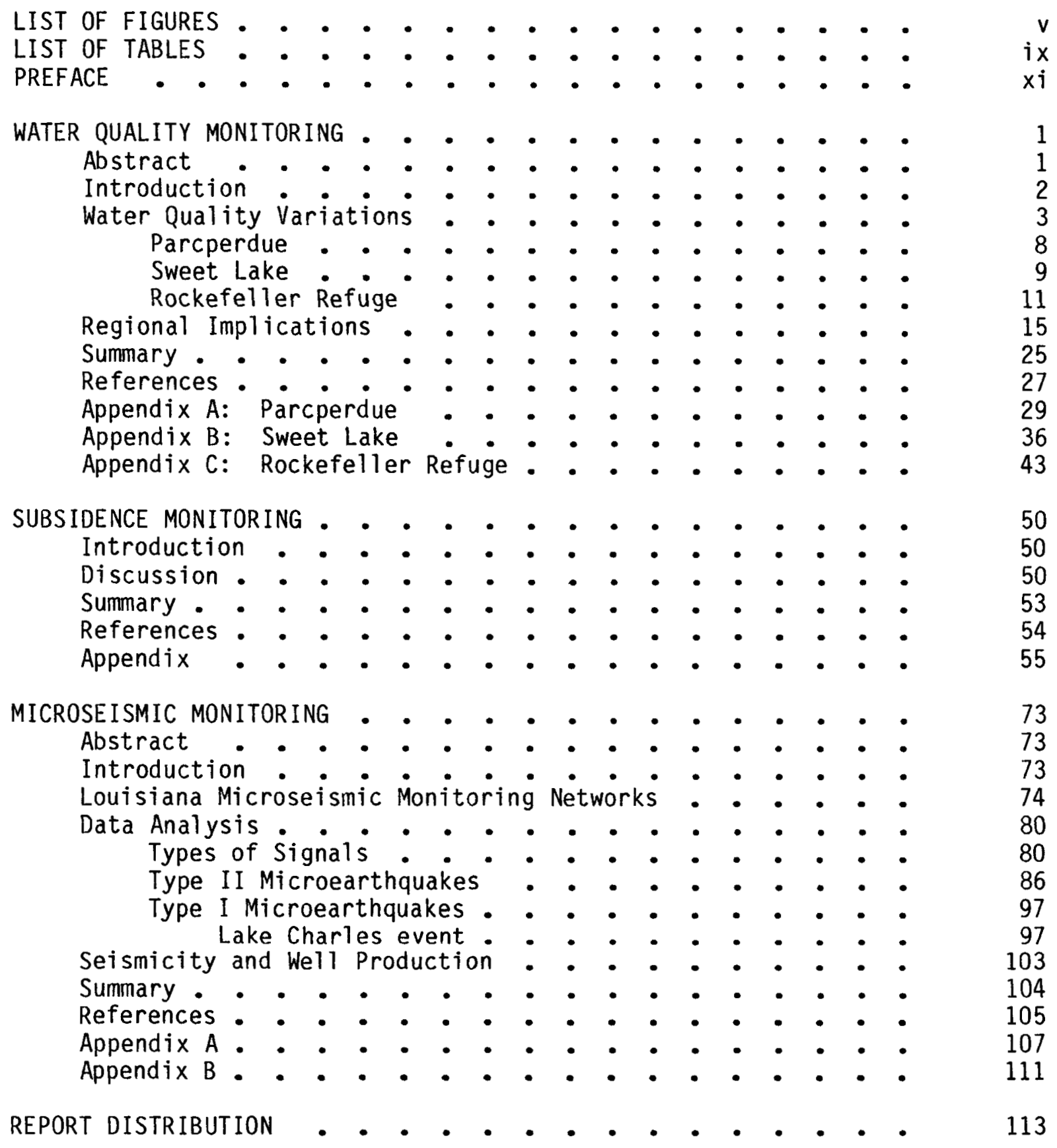




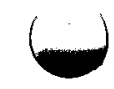

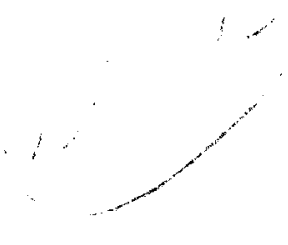

$\omega$ 


\section{LIST OF FIGURES}

FIGURE

Page

Water Quality Monitoring

1 Calcium/magnesium ratio versus time and calcium/magnesium mixing curves for surface and ground waters around the Parcperdue geopressured-geothermal prospect . . . . . . . . . .

2 Calcium/magnesium ratio versus time and calcium/magnesium mixing curves for surface and ground waters around the Sweet Lake geopressured-geothermal prospect . . . . . . . . . .

3 Calcium/magnesium ratio versus time and calcium/magnesium mixing curves for surface and ground waters around the Rockefeller Refuge geopressured-geothermal prospect . . . . . . . . . .

4 Ternary plot of dissolved constituents in surface waters from the Parcperdue geopressured-geothermal prospect . . . . . 17

5 Ternary plot of dissolved constituents in ground waters from the Parcperdue geopressured-geothermal prospect . . . . . . 18

6 Ternary plot of dissolved constituents in surface waters from the Sweet Lake geopressured-geothermal prospect . . . . . . 19

7 Ternary plot of dissolved constituents in ground waters from the Sweet Lake geopressured-geothermal prospect . . . . . .

8 Ternary plot of dissolved constituents in surface waters from the Rockefeller Refuge geopressured-geothermal prospect . . . 22

9 Ternary plot of dissolved constituents in ground waters from the Rockefeller Refuge geopressured-geothermal prospect . . . 23

10 Ternary plot of dissolved constituents in natural waters from design geopressured-geothermal prospects in southwestern Loui siana

Subsidence Monitoring

1 Elevation changes for benchmarks around the Sweet Lake geopressured-geothermal prospect . . . . . . • . . . . .

Geopressured-Geothermal Development and Coastal Subsidence in Louisiana (Appendix)

1 Location of geopressured-geothermal prospects, southwestern Louisiana

2 Subsidence rates for benchmarks around the Rockefeller Refuge geopressured-geothermal prospect, October 1981 to July 1984 . 


\section{LIST OF FIGURES (cont.)}

FIGURE

Page

3 Subsidence rates for benchmarks around the Rockefeller Refuge geopressured-geothermal prospect, October 1981 to June 1982 . .

4 Historical oil and gas development at Rockefeller Refuge . . .

5 Second-order residual surface for elevation changes for benchmarks around the Parcperdue geopressured-geothermal prospect, 1980-81

6 Historical oil, gas, and groundwater development at Parcperdue

Microseismic Monitoring

1 Locations of the DOE Sweet Lake, Parcperdue, and Rockefeller Refuge geopressured-geothermal prospects in Louisiana . . . . 75

2 Parcperdue seismic array . . . . . . . . . . 76

3 Sweet Lake seismic array . . . . . . . . . . . 77

4 Rockefeller Refuge seismic array . . . . . . . . 78

5 Regular type signals from Rockefeller Refuge network with geophysical exploration blast . . . . . . . . . . . 81

6 Type I event, Parcperdue network . • • • • • • • • • 83

7 Type II event, Parcperdue network . • . . • . • . • 84

8 Distribution of seismic events and well production at Parcperdue . • • • • • • • • • • • • • • • • • 85

9 Lake Charles radar summary chart, 27 June 1983, 2230 UTC • • • 88

10 Lake Charles radar summary chart, 27 June 1983, 2330 UTC . • • 88

11 Lake Charles radar summary chart, 28 June 1983, 0025 UTC . • • 89

12 Lake Charles radar summary chart, 28 June 1983, 0125 UTC • • • 89

13 Lake Charles radar summary chart, 28 June 1983, 0225 UTC • • • 90

14 Lake Charles radar summary chart, 28 June 1983, 0325 UTC . • . 90

15 Lake Charles radar summary chart, 28 June 1983, 0430 UTC . • . 91

16 Lake Charles radar summary chart, 17 April 1982, 0830 UTC • • 92 


\section{LIST OF FIGURES (cont.)}

FIGURE

Page

17 Lake Charles radar summary chart, 17 April 1982, 0930 UTC . . 92

18 Lake Charles radar summary chart, 17 April 1982, 1030 UTC • • 93

19 Lake Charles radar summary chart, 17 April 1982, 1130 UTC . . 93

20 Lake Charles radar summary chart, 17 April 1982, 1231 UTC • • 94

21 Lake Charles radar summary chart, 17 April 1982, 1330 UTC • • 94

22 Lake Charles radar summary chart, 17 Apri1 1982, 1435 UTC • • 95

23 Lake Charles radar summary chart, 17 April 1982, 1530 UTC • • 95

24 Lake Charles radar summary chart, 17 April 1982, 1630 UTC . • 96

25 Lake Charles radar summary chart, 17 April 1982, 1730 UTC • • 96

26 Locations of type I events, Parcperdue . • • • • • • • 98

27 Locations of type I events, Sweet Lake . • • • • • • • 100

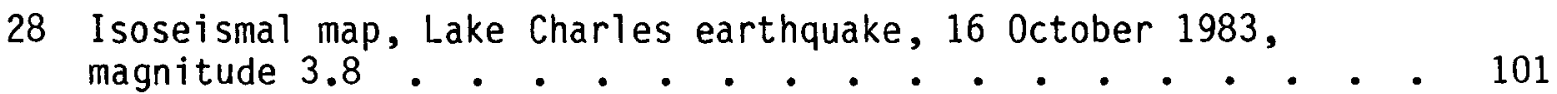




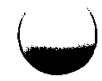

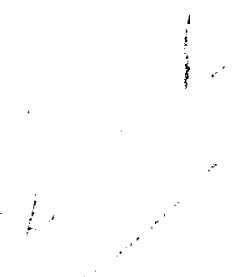

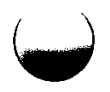

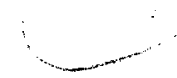




\section{LIST OF TABLES}

TABLE

Page

Water Qual ity Monitoring

1 Global mean concentrations of major ions in seawater and river water • • • • • • • • • • • • • • • • 4

2 Concentrations of major jons in DOE geopressured-geothermal project brines, southwestern Louisiana . . . . . . . . 6

3 Common drilling fluid additives . • . • . . . . . . 7

Microseismic Monitoring

1 Coordinates for Parcperdue, Sweet Lake, and Rockefeller Refuge seismic monitoring networks . . • . • • • • • • • 79

2 Type I events at Parcperdue . . . . . . . . . . . 99

3 Type I events at Sweet Lake . • . • . . • . . 102 
-

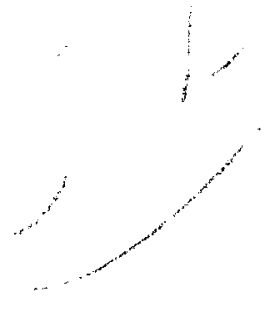

$\bullet$ 


\title{
PREFACE
}

This report describes environmental monitoring activities carried out by Louisiana State University (LSU) under U.S. Department of Energy Contract DE-AC08-81NV10174 for the period 1 November 1983 through 31 October 1984. Other aspects of the LSU technical support program completed under prior contracts were covered in final form in reports preceding this one. During the twelve-month contract period, the Louisiana Geological Survey, aided by subcontractors, monitored microseismic activity, land-surface subsidence, and surface and ground-water quality at three designed geopressuredgeothermal test well sites in Louisiana. Don Stevenson supervised microseismic monitoring activities, and Drukell Trahan coordinated water quality and land-surface subsidence studies. This is a progress report in the sense that it discusses program components, provides raw data, and presents preliminary interpretations. The environmental monitoring program continues and will be the subject of subsequent annual reports.

\author{
C. G. Groat
}


-

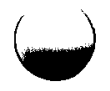




\author{
WATER QUALITY MONITORING \\ by D. B. Trahan
}

\title{
Abstract
}

Several methods have been used to separate natural water quality variations from man-induced variations in the analyses of water samples from geopressured-geothermal prospects in southwestern Louisiana. Concentrationversus-time curves, ratio comparisons, and ternary plots have served to distinguish saltwater intrusion from drilling fluid or brine contamination.

Saltwater intrusion is the dominant source of variation in most natural waters in southwestern Louisiana. The distinction between saltwater intrusion and other forms of contamination is made by looking for signals in the concentrations of constituents not common to seawater.

In ground waters from the Parcperdue geopressured-geothermal prospect, anomalous concentrations of drilling fluid constituents occurred during the drilling phase, indicating drilling fluid contamination. Another anomaly in surface and ground waters corresponded to a leak in the brine disposal pit located on the site. Anomalies in the concentrations of drilling fluid constituents also occurred in Sweet Lake prospect waters. In addition, a casing leak may be responsible for anomalies that occurred during cleanup of the disposal we11 at Sweet Lake.

At the Rockefeller Refuge prospect, surface waters illustrate a negative trend in concentrations of seawater components that may be due to clay mineral flocculation, cation exchange, or adsorption and absorption properties. Chemical analyses of ground water from the shallow aquifer show higher concentrations of seawater components than those from the deeper aquifer, indicating the 
connection of the shallow aquifer to the surface. Drilling fluid contamination is also evident in ground waters during the drilling phase.

Regional trends in water quality are evident in ternary plots. The main trend is a transition from fluvial waters at Parcperdue to marine waters at Rockefeller Refuge. Sweet Lake waters, which border the uplands and marshlands, fluctuate between these two extremes. Depth of ground water is also a distinguishing characteristic in the regional analysis.

The water quality classification schemes in this study are useful for determining the effects of geopressured-geothermal development on the quality of fresh waters. Concentration-versus-time curves and ionic ratios are most useful in local contamination studies, and ternary plots are effective in regional characterizations. The detection of contamination should not rely on one method or one constituent, but on groups of related constituents which are quantified using a variety of methods.

\section{Introduction}

Unless the direct monitoring of a contaminant plume is in progress, water quality monitoring should be considered a continuous process. Water quality monitoring at U.S. Department of Energy (DOE) geopressured-geothermal test sites involves the detection of potential contaminants in near-surface aquifers and surface waters which are considered to be relatively free of contamination. An anomalous concentration of a constituent at one point in time must be considered relative to the concentration of that constituent over a much longer span of time. The longer span of time must include observations before and after the anomaly to detect all possible sources of variation.

Surface- and ground-water samples from geopressured-geothermal prospects in southwestern Louisiana have been analyzed to determine the potential effects of site activities on water quality. Sampling of surface and ground waters at 
Parcperdue and of surface waters at Sweet Lake was initiated prior to site activity; however, drilling was already in progress when the first ground-water samples were taken at Sweet Lake and when the first surface- and ground-water samples were taken at Rockefeller Refuge.

A comparison of temporal water-quality variations with site activities yields information about the possible effects of drilling, cleanup, disposal, and production at each test site. Reduction of water quality data into ionic ratios and groups allows for the distinction of variations caused by natural and man-induced contaminant plumes. These may include saltwater intrusion, runoff, aquifer recharge, and fluid escape from unprotected or leaking production and disposal wells, tanks, and pits.

\section{Water Quality Variations}

The major natural source of contamination in Louisiana's coastal and ground waters is saltwater (seawater) intrusion. Saltwater intrusion is facilitated by several mechanisms, including subsidence, sea level rise, natural or controlled decreases in freshwater runoff and ground-water recharge, and by seasonally high pumpage rates from aquifers. Saltwater fluctuations in an area may be detected when constituents common to seawater are the major causes of variation in water quality. The most abundant constituents in seawater are chloride, sodium, sulfate, magnesium, and calcium; the constituents usually abundant in river water are bicarbonate, calcium, sulfate, chloride, and sodium (Table 1).

The effect of seawater intrusion in streams or ground waters is to increase the concentrations of ions common to seawater in the intruded water. However, during periods of high precipitation and surface runoff, stream (river) and ground waters may push back the saltwater interface by mixing and 
TABLE 1. Global mean concentrations (in $\mathrm{mg} / \mathrm{L}$ ) of major ions in seawater (Rankama and Sahama, 1950) and river water (Livingstone, 1963).

\begin{tabular}{|c|c|c|c|c|}
\hline Major Ions & in Seawa & ter & Major Ions in & River Water \\
\hline Chloride & 18,980 & $\mathrm{mg} / \mathrm{L}$ & Bicarbonate & $58.4 \mathrm{mg} / \mathrm{L}$ \\
\hline Sodium & 10,561 & & Calcium & 15 \\
\hline Sulfate & 2,649 & & Sulfate & 11.2 \\
\hline Magnesium & 1,272 & & Chloride & 7.8 \\
\hline Calcium & 400 & & Sodium & 6.3 \\
\hline Potassium & 380 & & Magnesium & 4.1 \\
\hline Bicarbonate & 140 & & Potassium & 2.3 \\
\hline Boron & 4.6 & & Nitrate & 1.0 \\
\hline Ammonia & 0.5 & & & \\
\hline
\end{tabular}


diffusion. When this occurs, dilution may occur, and ionic ratios of the mixed waters may approach the ratios found in runoff.

The chemistries of stream and ground waters are highly variable, depending on area geology, hydrology, and climate, although major deviations from average chemistries are rare. The chemistry of ground waters is more highly variable than that of seawater or stream waters. Ground-water chemistry may reflect the geochemical environment of deposition, the post-depositional diagenesis of clays, and the hydrologic communication of ground waters and surface waters. Ground-water chemistry varies greatly with depth, from fresh water near the surface to brines at depth. Project brines contain mostly chloride, sodium, and calcium (Table 2). The concentrations of the secondary constituents, potassium, magnesium, bicarbonate and sulfate, vary geographically. Parcperdue brine contains secondary concentrations of bicarbonate, sulfate, magnesium, strontium, and potassium, whereas the Sweet Lake and Rockefeller Refuge brines are depleted in sulfate and contain strontium, potassium, magnesium, bicarbonate, and ammonia (Table 2).

Another potential source of contamination during the development of any well is drilling fluids. During drilling, these fluids may be spilled onto the surface and become entrained in site drainage. In addition, casings are set after an interval is drilled and logged so that drilling fluids may escape into ground waters in the time between drilling and casing emplacement. Common constituents in drilling fluids which may signal stream or aquifer contamination include various carbon compounds, barium, sodium, calcium, potassium, chromium, lead, ammonia, sulfate, and chloride (Table 3 ) in addition to the constituents of ground waters which are in contact with the well at lower horizons. 
TABLE 2. Concentrations of major ions (in $\mathrm{mg} / \mathrm{L}$ ) in DOE geopressured-geothemal project brines, southwestern Louisiana.

Parcperdue

\begin{tabular}{|c|c|c|c|c|c|c|c|c|}
\hline Chloride & 55,720 & $\mathrm{mg} / \mathrm{L}$ & Chloride & 99,650 & $\mathrm{mg} / \mathrm{L}$ & Chloride & 58,700 & $\mathrm{mg} / \mathrm{L}$ \\
\hline Sodium & 33,890 & & Sodium & 41,800 & & Sodium & 30,200 & \\
\hline Calcium & 1,710 & & Calcium & 12,500 & & Calcium & 3,643 & \\
\hline Bicarbonate & 1,540 & & Strontium & 1,220 & & Potassium & 780 & \\
\hline Sulfate & 522 & & Potassium & 990 & & Strontium & 473 & \\
\hline Magnesium & 262 & & Magnesium & 700 & & Ammonia* & 297 & \\
\hline Strontium & 245 & & Bicarbonate & 281 & & Bicarbonate & 232 & \\
\hline Potassium & 176 & & Ammonia* & 111.2 & & Barium & 60 & \\
\hline Boron & 60.2 & & Barium & 110 & & Boron & 38.5 & $\cdot$ \\
\hline Ammonia * & 50.8 & & Boron & 50.6 & & Manganese & 1.4 & \\
\hline
\end{tabular}

Rockefeller Refuge

* Reported as $\mathrm{NH}_{3}$ in analysis; converted to $\mathrm{NH}_{4}$. 


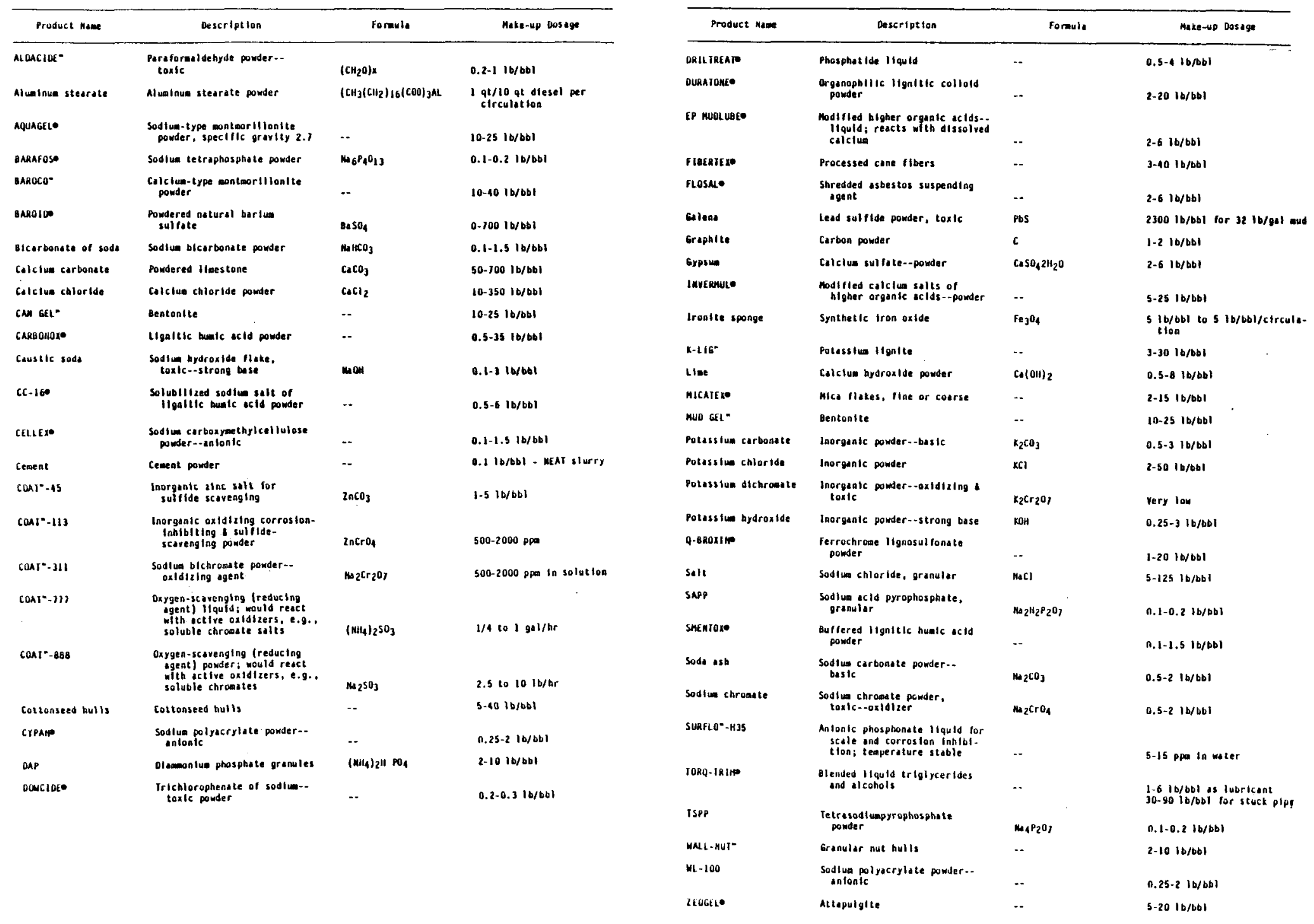

TABLE 3. Common drilling fluid additives (modified from NL Baroid, 1983). 
Parcperdue

Changes in the concentrations of major and minor constituents with time may indicate a number of variations. In general, surface waters at Parcperdue exhibit small background variations which are probably attributable to seasonal effects. Anomalies in the concentrations of potassium, magnesium, boron, ammonia, total organic carbon, arsenic, barium, manganese, and mercury during drilling in March 1981 could be associated with contamination by drilling fluids (App. A). Greater concentrations of these constituents occur at Bayou Parcperdue; however, this sampling station is the farthest removed from the test site, and little rainfall had occurred for solutes to be carried from the test site to the station. An associated increase in turbidity indicates a nearby source of contamination or the mixing of stream-bottom muds which contain contaminants from an earlier date.

Concentrations of most major and minor constituents in Parcperdue waters were greatest during November 1982 (App. A), when a brine disposal pit was found to be leaking (Trahan, 1984). Stations downstream from the test site were most affected, implying that brine contamination was the probable cause. Similar anomalies were evident in ground waters during the same time period for total organic carbon, arsenic, barium, and mercury (App. A). The sampled aquifer at Parcperdue is unconfined (Wrighton and others, 1981) so that certain brine constituents may have leached down into ground waters. In addition, major anomalies in ground water occurred in the concentrations of ammonia, total organic carbon, and barium during drilling at Parcperdue (App. A). These constituents are all very probable drilling fluid contaminants either from the uncased hole or the drilling fluid pit.

Drilling fluid contamination is relatively easy to distinguish in natural waters because drilling fluid constituents rarely occur naturally. The chemical similarity of seawater and brine and a close communication between surface 
and shallow ground waters precludes the sole use of concentration-versus-time curves to distinguish between these contamination sources. Another way of identifying possible contamination sources in natural waters is to compare ionic ratios of natural waters with ionic ratios of known contamination sources (i.e., mixing diagrams). Comparisons with project brines and the mean world compositions of seawater and river water should indicate the relative contributions of these sources to mixing in natural waters.

The calcium/magnesium ratio $(\mathrm{Ca}+2 / \mathrm{Mg}+2)$ is probably the most illustrative. Seawater typically has a low $\mathrm{Ca}+2 / \mathrm{Mg}+2$ ratio compared to river and ground waters (Tables 1 and 2). In surface waters at Parcperdue, this ratio shows a relatively consistent decline through the sampling interval, indicating saltwater intrusion (Fig. 1). An anomaly in November 1982 corresponded to brine contamination from a leaking pit. The ratio comparison indicates mixing primarily with river water (Fig. 1). The $\mathrm{Ca}+2 / \mathrm{Mg}^{+2}$ ratio is highest for the deepest sampled ground waters at Parcperdue. An initial decrease in this ratio may indicate saltwater intrusion, but fluctuations to higher ratios may represent a decrease in pumpage rates for the aquifer. A plot of calcium versus magnesium for these waters also depicts the higher ratios of deeper waters (Fig. 1), but as with surface waters, all points lie on or parallel to the line indicating mixing with river water. This relationship could reflect the fluvial deposition of these waters or the interconnection of these ground waters with surface waters.

\section{Sweet Lake}

The possible effects of drilling operations are obvious in the concentration-versus-time curves for surface and ground waters at Sweet Lake (App. B). In surface waters, anomalous concentrations for most constituents occurred during drilling. Sodium, total organic carbon, and barium, which are common 


\section{SURFACE WATERS}
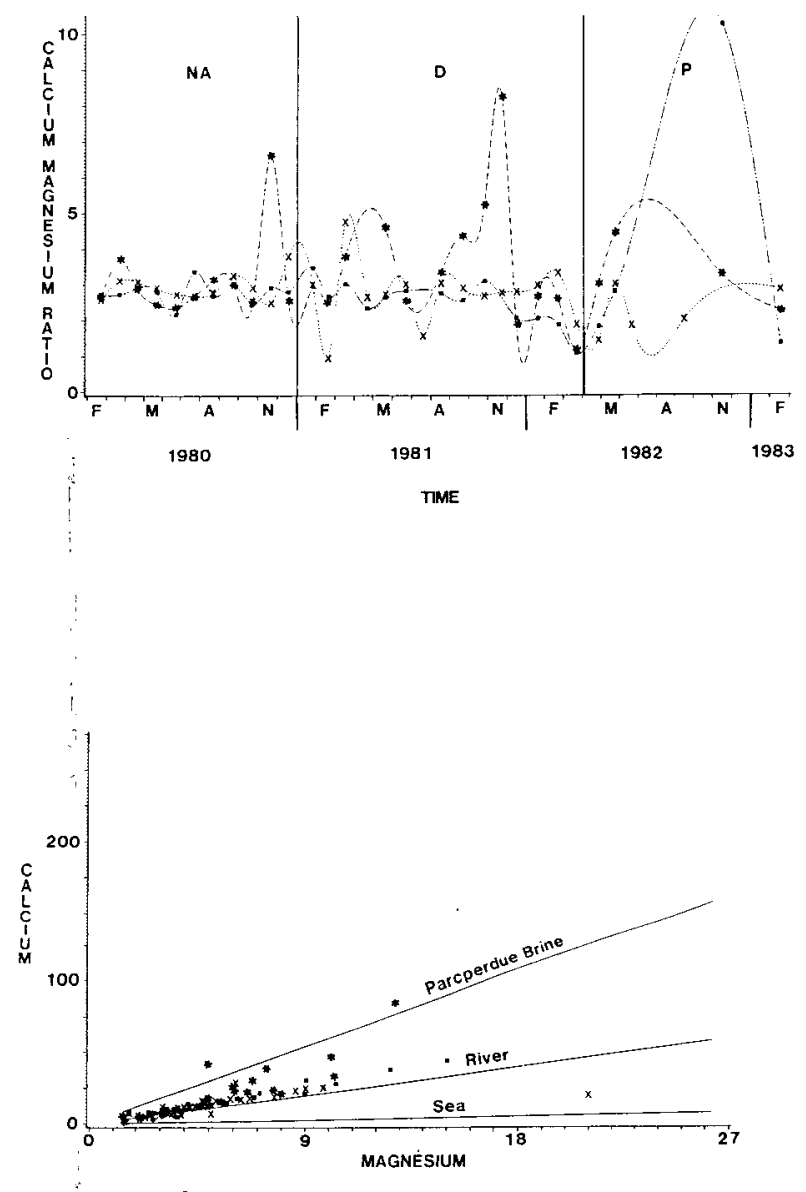

Calcium/magnesium ratio versus time and calcium/magnesium mixing
curves for surface and ground waters around the Parcperdue geopres-
sured-

Figure 1. Calcium/magnesium ratio versus time and calcium/magnesium mixing
curves for surface and ground waters around the Parcperdue geopres-
sured

Figure 1. Calcium/magnesium ratio versus time and calcium/magnesium mixing
curves for surface and ground waters around the Parcperdue geopres-
sured-geothermal prospect (see legend in Appendix A for symbol defi$\therefore \quad$ nitions).

\section{GROUND WATERS}
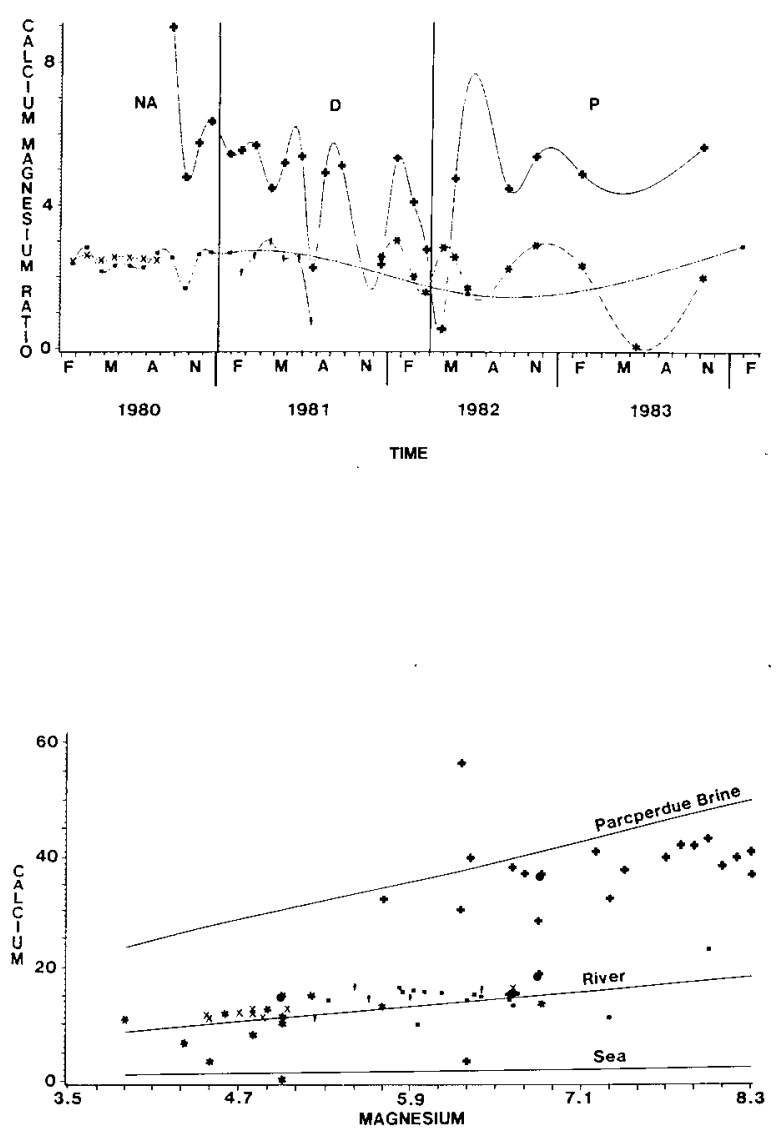

Figure 1. Calcium/magnesium ratio versus time and calcium/magnesium mixing
curves for surface and ground waters around the Parcperdue geopres-
sured-geothermal prospect 
constituents of drilling fluids, may signal contamination from this source (App. B). A similar variability is evident in ground waters, although a greater anomaly may have occurred during disposal-well cleanup, which contributed to the dilution of magnesium, calcium, boron, chloride, arsenic, and barium and an increase in the concentrations of ammonia, total organic carbon, and lead (App. B). The temperature of ground waters also increased during cleanup. This contamination event may have been facilitated by a leak in the casing at 6000 feet which was discovered during cleanup (Bebout and others, 1983).

As would be expected, $\mathrm{Ca}+2 / \mathrm{Mg}+2$ ratios are highest in the site drainage due to the upland position of the northernmost surface water station (Fig. 2). The lower $\mathrm{Ca}+2 / \mathrm{Mg}^{+2}$ ratios in Square Lake and Sweet Lake depict the influence of tidal exchange in these lakes. Although the ratioversus-time curve shows no trend in the $\mathrm{Ca}+2 / \mathrm{Mg}+2$ ratio, the mixing diagram indicates that the dominant source of variation in surface waters is mixing between stream flow and seawater (Fig. 2). The $\mathrm{Ca}+2 / \mathrm{Mg}+2$ ratios in ground waters represent the variation between drilling and cleanup operations. Low ratios during cleanup indicate probable saline contamination from aquifers below the subsurface freshwater-saltwater interface. Comparison with known ionic ratios implies mixing between river water and brines (Fig. 2 ). This aquifer was probably deposited in a fluvial environment. However, the aquifer is confined and probably receives little surface water recharge compared to the circulation of fluids from depth.

\section{Rockefeller Refuge}

Many constituents in Rockefeller Refuge surface waters show a marked decrease in concentration through the sampling period (App. C). The reason for this is unclear. Sea level rise and subsidence, well documented along the Louisiana Gulf Coast, have increased the rate of saltwater intrusion, and the 


\section{SURFACE WATERS}
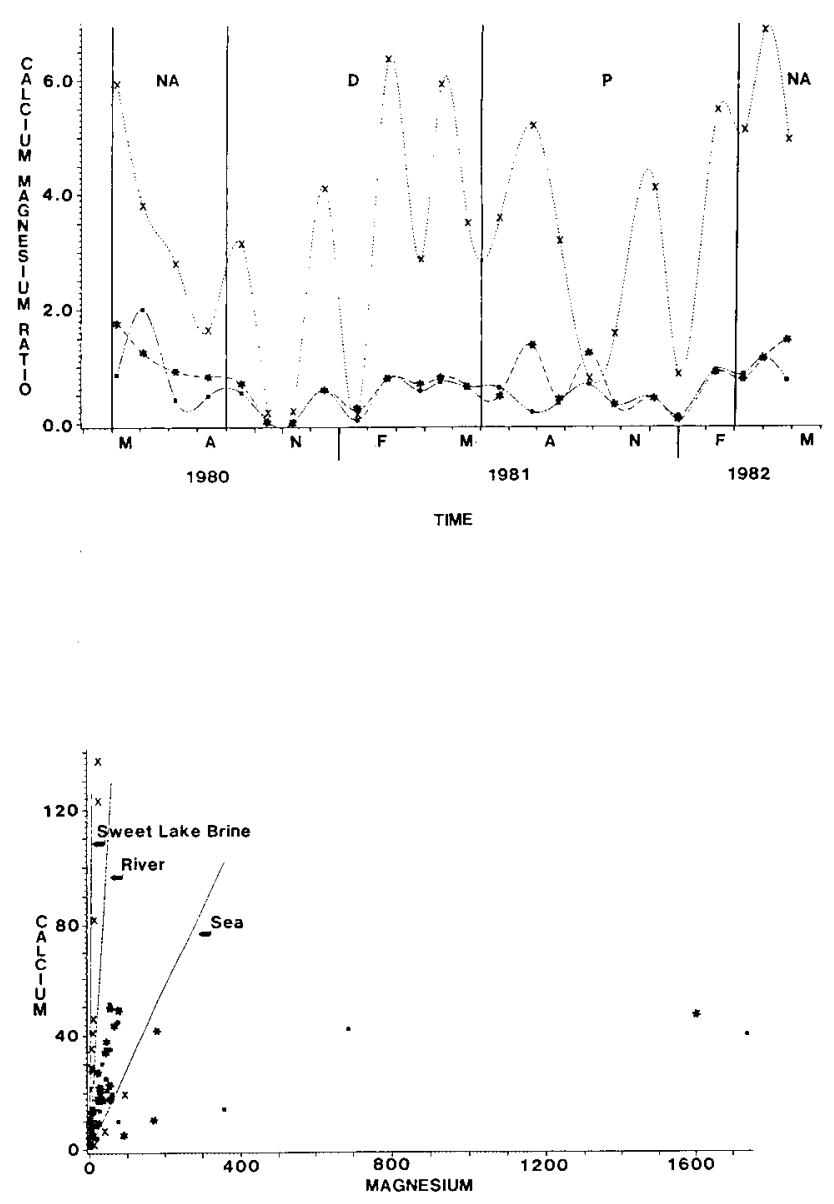

\section{GROUND WATERS}
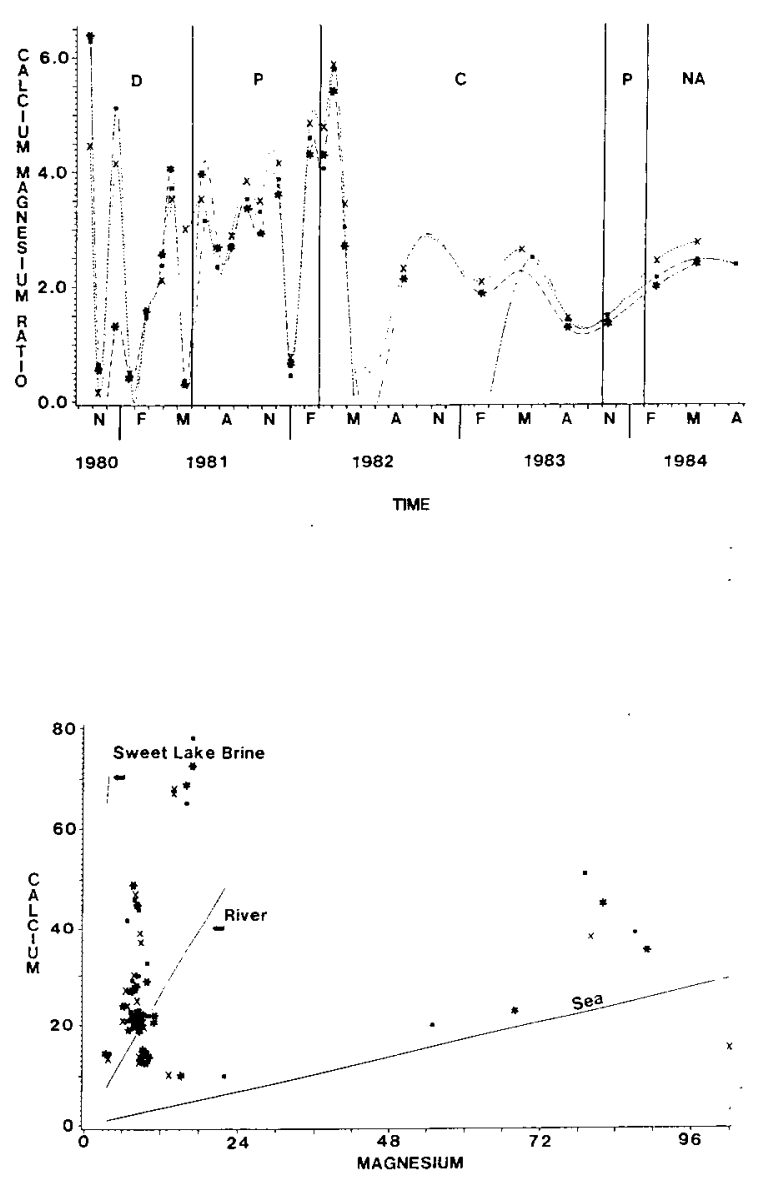

Figure 2. Calcium/magnesium ratio versus time and calcium/magnesium mixing curves for surface and ground waters around the Sweet Lake geopressured-geothermal prospect (see legend in Appendix B for symbol definitions). 
concentrations of constituents common to seawater should therefore be increasing. The observed behavior of the constituents in Rockefeller Refuge surface waters may be due to a process such as cation exchange or adsorption/absorption by clay minerals (Grim, 1968). Recent field investigations in the area disclosed a large amount of suspended matter and high sedimentation rates presumably caused by clay mineral development. Clay flocculation is typically a dominant process in which fresh water from surface runoff mixes with seawater in estuaries (Potter, Maynard, and Pryor, 1980). The $\mathrm{Ca}+2 / \mathrm{Mg}+2$ ratio may support this conclusion (Fig. 3 ). The trend in this ratio with time does not indicate a decrease in the ratio, as would be expected with saltwater intrusion, but the comparison of calcium versus magnesium for these surface waters does follow the seawater mixing curve (Fig. 3 ). Mixing with seawater is therefore the dominant process in Rockefeller Refuge surface waters.

For Rockefeller Refuge ground waters, many concentration curves (App. C) reflect an observation made earlier: that the shallow aquifer $(-310 \mathrm{ft}$ MSL) is more saline than the deeper aquifer (-660 ft MSL) (Bebout and others, 1983; Trahan, 1984). The concentrations of potassium, calcium, and manganese particularly show this trend. Chloride and magnesium concentrations are also consistently higher in the shallow well, although the difference in concentrations between the two aquifers is small (App. C). This phenomenon may be due to several causes. The shallow aquifer may be recharged to the north of the Rockefeller Refuge prospect where the Mermentau fluvial system has incised into or near the top of the aquifer, or saltwater intrusion from the south may be greater in the shallow aquifer, a result of greater permeabilities in the sand and gravel which comprise it. Alternatively, the variation in chemistry between these aquifers may be a response to differences in clay mineralogy, that is, the cation exchange capacity and the adsorption and absorption 


\section{SURFACE WATERS}
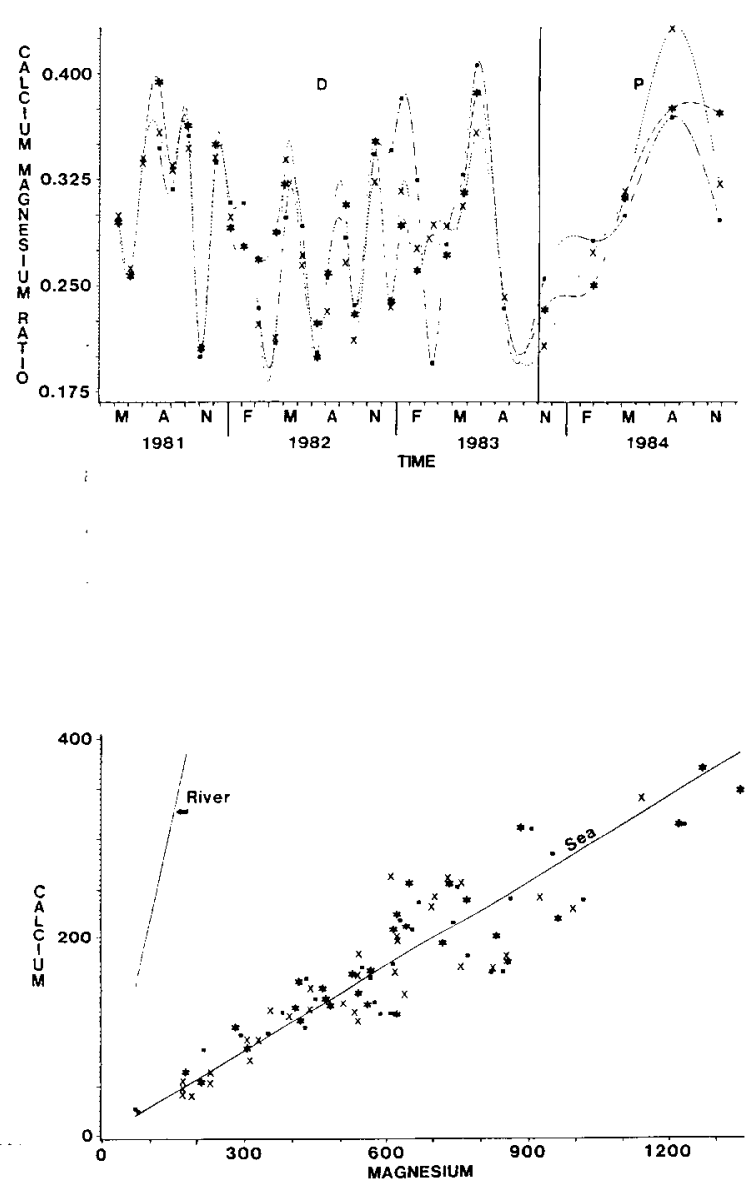

\section{GROUND WATERS}
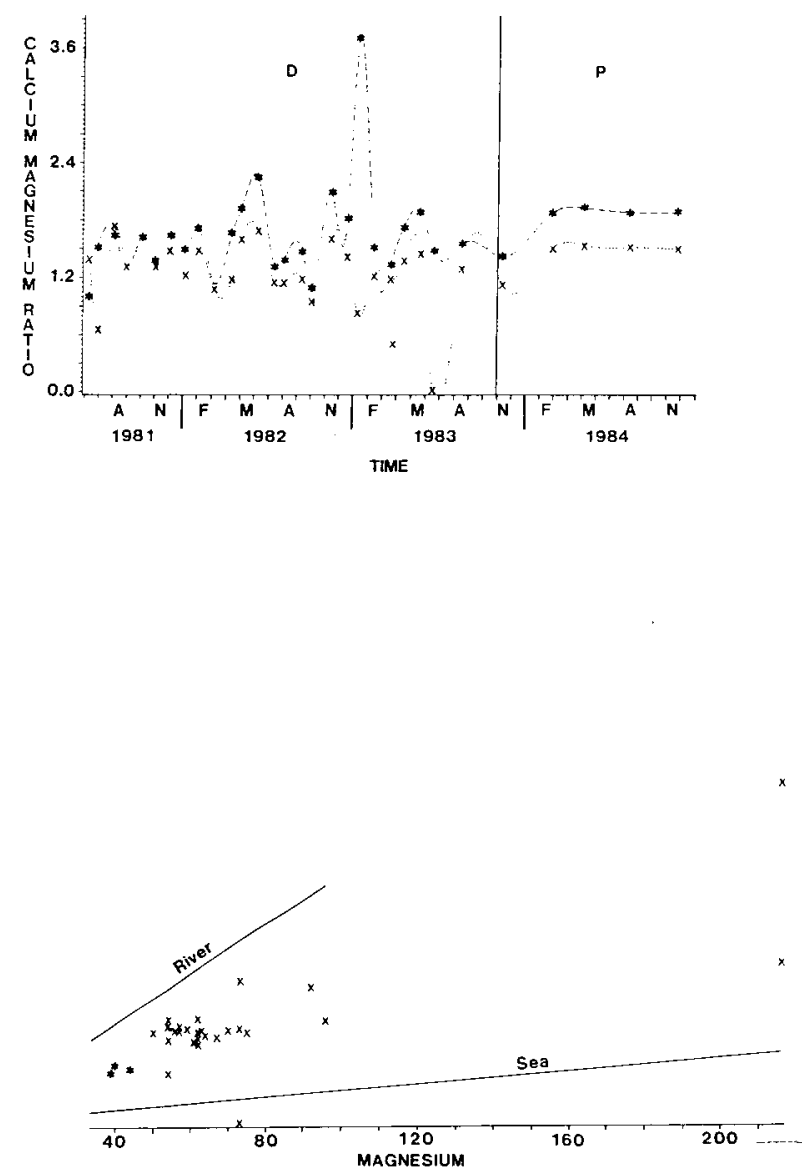

$\therefore$,
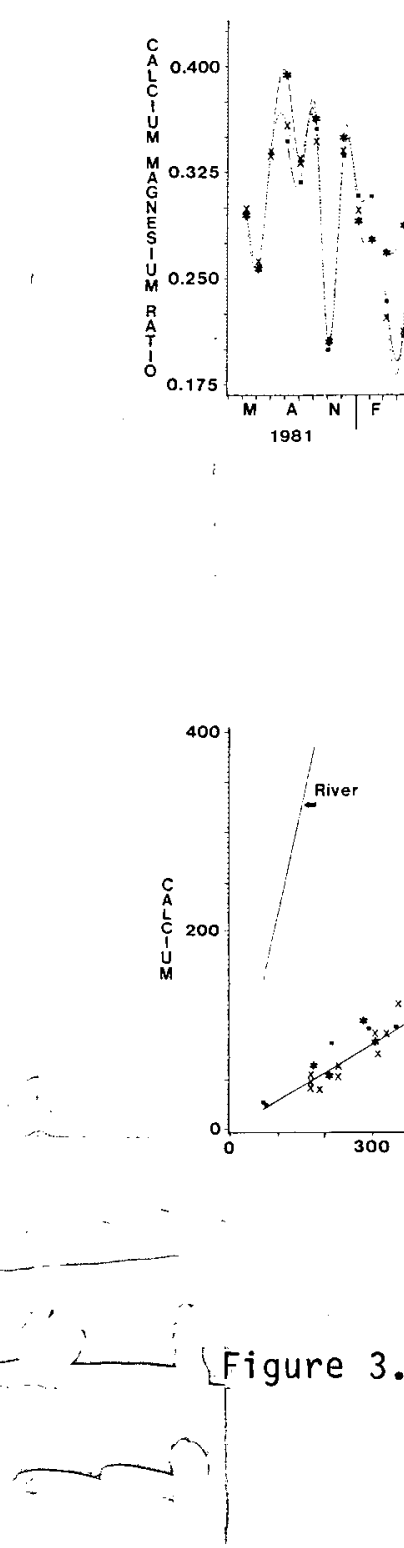

Calcium/magnesium ratio curves for surface and ground waters

and calcium/magnesium mixing geopressured-geothermal prospect (see legend in Appendix $C$ for symbol definitions). 
properties of clays within and adjacent to the aquifer. These effects cannot be singled out without detailed hydrogeologic and mineralogic evaluations.

The effects of well drilling may be evident in the concentration-versustime profiles. Arsenic, barium, lead, and cadmium reach their highest concentrations during drilling (App. C). The piezometric head of the deep $(-660 \mathrm{ft}$ MSL) aquifer is also lowest during this phase (App. C). Another anomaly is evident at the end of drilling (App. C). Decreases in the concentrations of sodium, magnesium, chloride, and barium and an increase in boron may indicate a connection between the 15,000-ft borehole and surrounding aquifers.

The $\mathrm{Ca}+2 / \mathrm{Mg}^{+2}$ ratio substantiates the varied chemistry of the two near-surface aquifers at Rockefeller Refuge (Fig. 3). Lower $\mathrm{Ca}+2 / \mathrm{Mg}+2$ ratios in the shallow aquifer imply relatively greater saltwater intrusion in the shallow aquifer. Furthermore, the mixing diagram illustrates that the $\mathrm{Ca}+2 / \mathrm{Mg}^{+2}$ ratio for ground waters falls between the theoretical mixing curves for river water and seawater, implying connection between these aquifers and the surface (Fig. 3 ).

\section{Regional Implications}

Geopressured-geothermal prospects in southwestern Louisiana are, by chance, located in a spectrum of coastal environments. The Parcperdue prospect is located in Pleistocene uplands formed by historic Mississippi River aggradation. In contrast, the Rockefeller Refuge prospect is located in Holocene marshlands formed by coastal mudflat accretion, and the Sweet Lake prospect is next to the boundary between Pleistocene uplands and Holocene marshlands (Groat and others, 1982; Bebout and others, 1983). As such, variations in surfacewater quality between the prospects should reflect differences between these coastal environments. Ground-water quality may not show such variations because of several complex processes, including cation exchange of clays, 
dispersion, and diffusion. Ground-water chemistries may indicate the depositional environment of the aquifer and any amount of mixing between other aquifers and surface waters. Post-depositional diagenesis may also cause variations in ground-water quality.

A classification scheme based on the work of Piper (1944) enables the comparison of waters from the range of coastal environments represented by the three geopressured-geothermal prospects. In this scheme a ternary plot of major cationic and anionic pairs allows for a general grouping of natural waters around the prospects. In Figures 4-10, patterned areas represent the densest clustering of points for each sampling station, and line boundaries represent wider variations in water chemistry.

Parcperdue surface and ground waters are chemically similar, supporting an earlier conclusion (Wrighton and others, 1981) that these waters are interconnected (Figs. 4-5). The generally greater concentration of bicarbonate in ground waters is probably attributable to the fact that saltwater intrusion is a much slower process in ground waters than in surface waters. In addition, the chemistry of ground water from the deepest (180-ft) well is consistently different from the chemistry of shallower ground waters (Fig. 5). The variation is an increase in calcium and magnesium and a decrease in sodium and potassium. These elements are usually involved in cation exchange reactions in which calcium and magnesium in clays are exchanged for sodium and potassium (Grim, 1968). Cation exchange is therefore a likely cause for this variation. Sweet Lake surface and ground waters (Figs. 6-7) are much more varied chemically than Parcperdue waters probably because of the closer proximity of the Sweet Lake prospect to the saltwater interface (Trahan, 1984). In addition, Sweet Lake ground waters exhibit generally higher concentrations of seawater components than do Parcperdue ground waters (Fig. 7). The effects of 


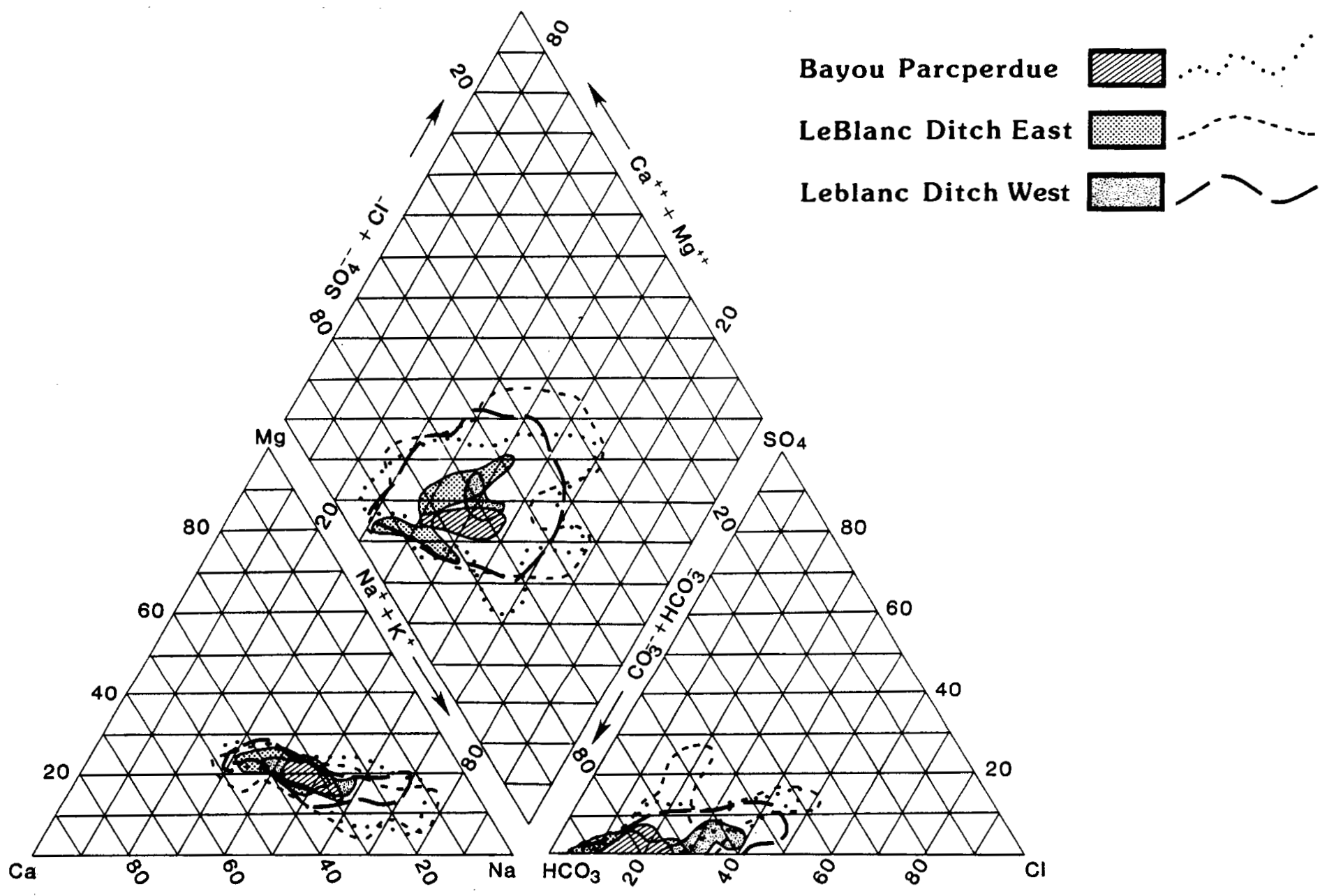

Figure 4. Ternary plot of dissolved constituents in surface waters from the Parcperdue geopressured-geothermal prospect. 


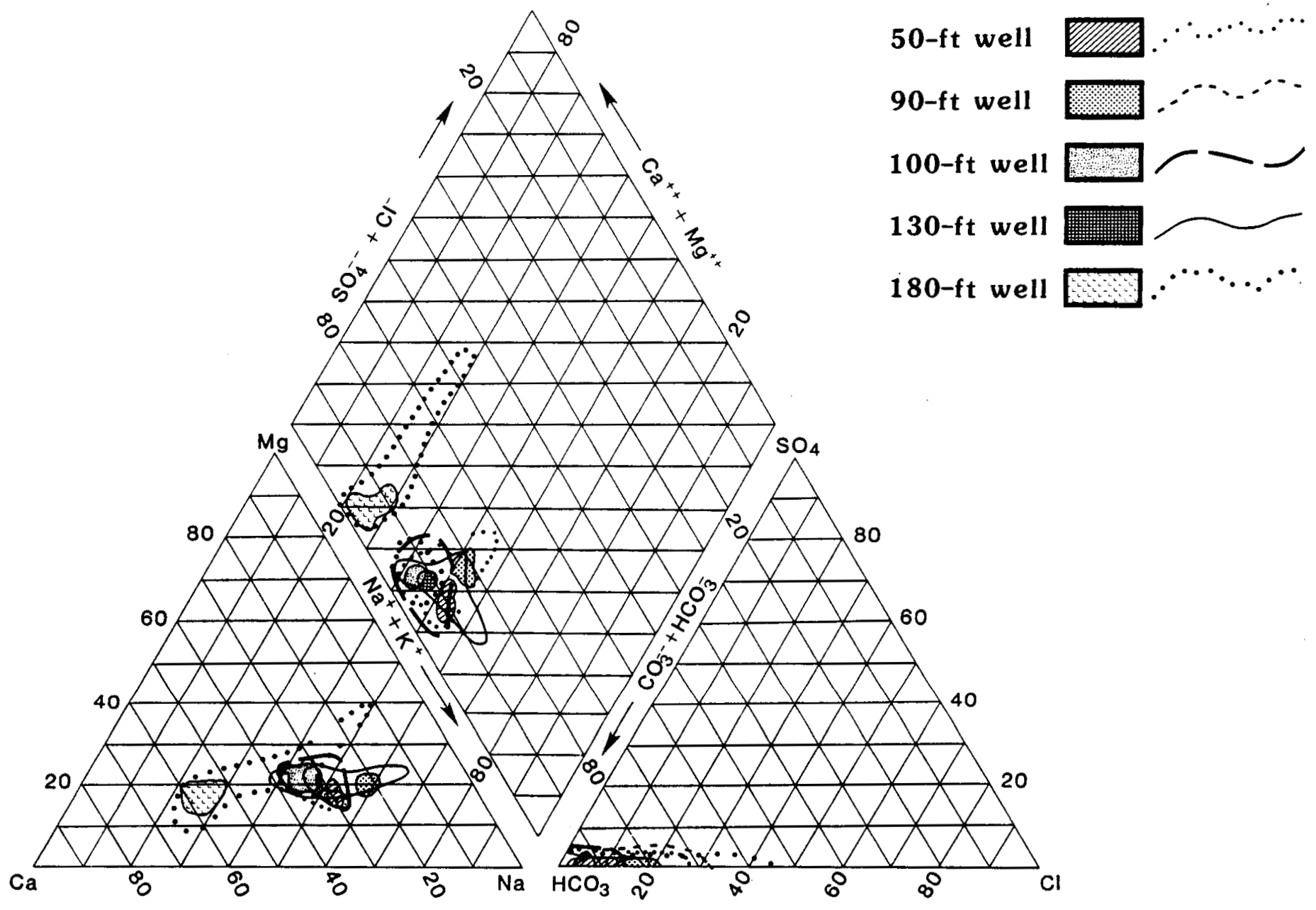

Figure 5. Ternary plot of dissolved constituents in ground waters from the Parcperdue geopressured-geothermal prospect. 


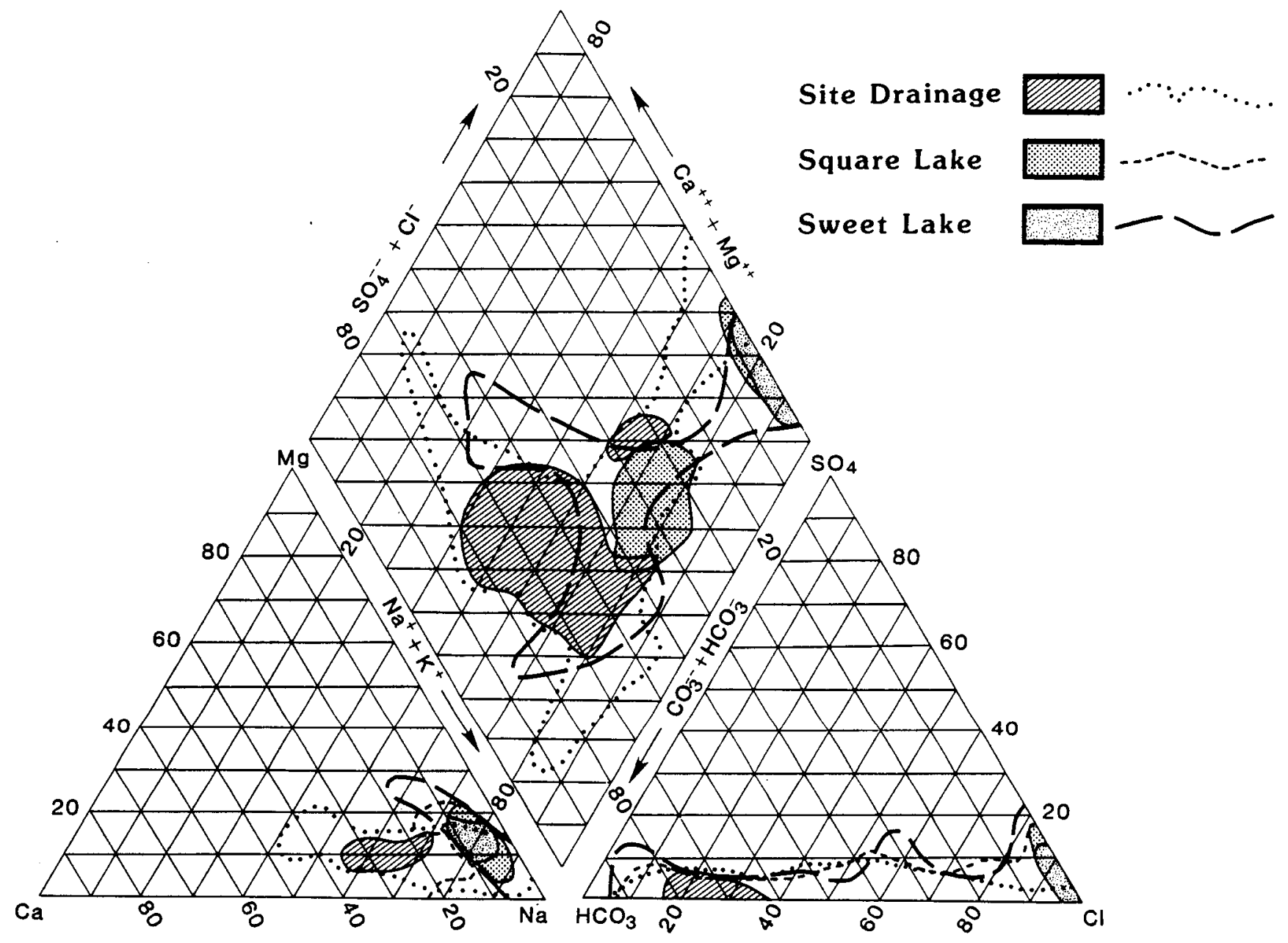

Figure 6. Ternary plot of dissolved constituents in surface waters from the Sweet Lake geopressured-geothermal prospect. 


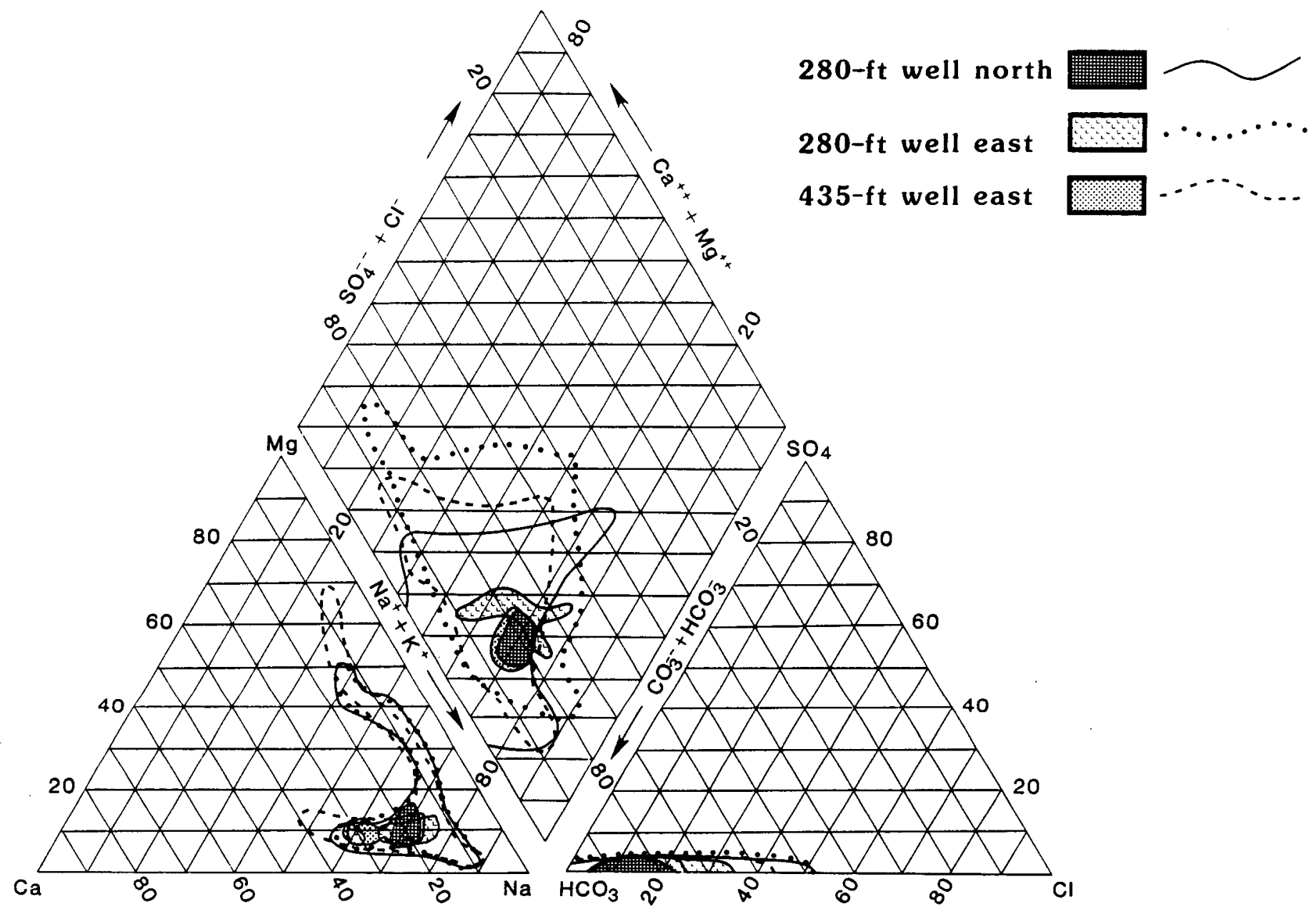

Figure 7. Ternary plot of dissolved constituents in ground waters from the Sweet Lake geopressured-geothermal prospect. 
saltwater intrusion and tidal variation are more obvious in Sweet Lake surface waters. At Sweet Lake, ground waters are less varied than surface waters.

Both surface waters and ground waters at Rockefeller Refuge indicate a dominantly seawater chemistry (Figs. 8-9). The variation in surface waters is probably caused by periods of increased surface runoff or tidal fluctuations or both. The ternary plot for ground waters substantiates the trend observed in concentration curves, that the chemistry of the shallow aquifer is closer to seawater than that of the deeper aquifer (Fig. 9). This similarity to surface waters implies a connection between the shallow aquifer and the surface.

A summary diagram of waters from all prospects (Fig. 10) illustrates the trend in surface-water quality across the range of environments included in this study. Although there is usually a large variation in chemistry at one particular site, the general trend is from waters rich in calcium bicarbonate or magnesium bicarbonate in upland terraces to waters rich in sodium chloride in the marshlands (Fig. 10).

Ternary plots may be useful in characterizations of regional trends, but are less useful in local contamination studies unless contamination causes a strong deviation from normal (plotted) characteristics.

Geothermal brines plot very close to seawater in the ternary plot (Fig. 10). The percentages of major cationic and anionic pairs plot within the range of percentages for Sweet Lake and Rockefeller Refuge surface waters, which are, as was discussed earlier, strongly influenced by seawater intrusion. Seawater and brine contamination are therefore undifferentiable in the ternary plot. Seawater or brine contamination would also cause no discernible variations in Rockefeller Refuge surface waters and only slight variations in Rockefeller Refuge ground waters. The notable exceptions are the suites of observations with higher bicarbonate percentages (Fig. 10). These observations represent the normal chemistries of waters within the impoundment at Rockefeller Refuge 


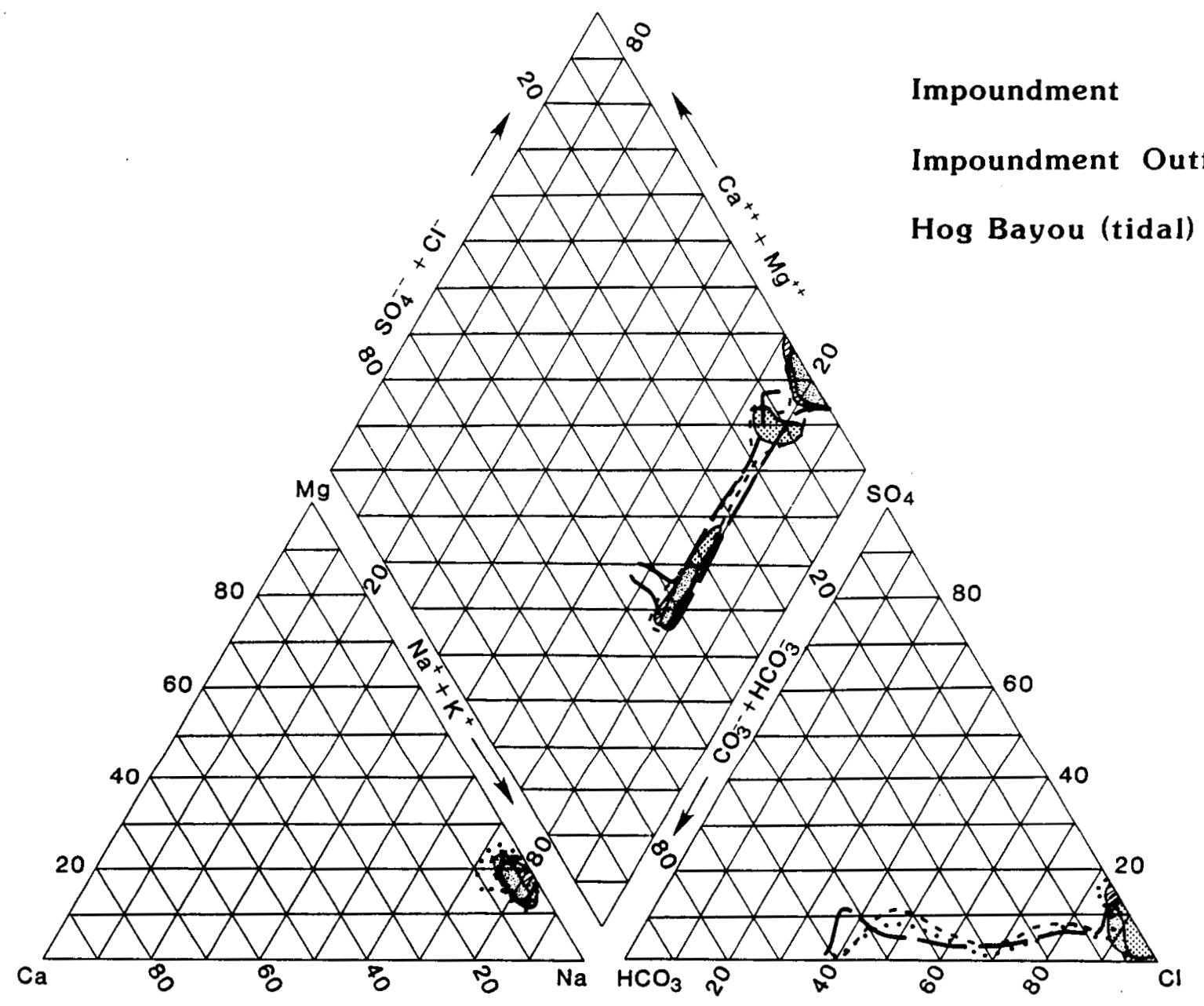

Figure 8. Ternary plot of dissolved constituents in surface waters from the Rockefeller Refuge geopressured-geothermal prospect. 


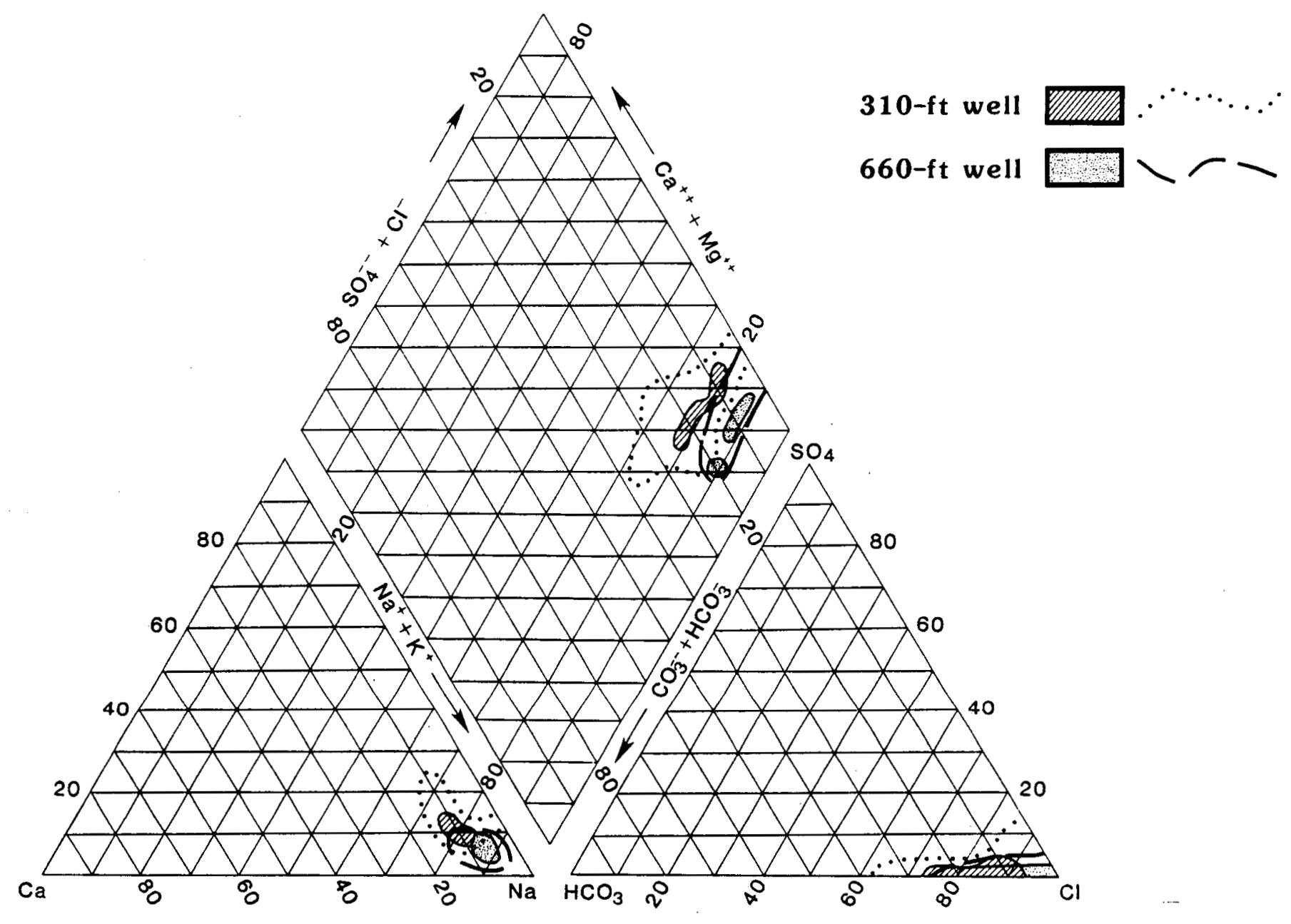

Figure 9. Ternary plot of dissolved constituents in ground waters from the Rockefeller Refuge geopressured-geothemal prospect. 


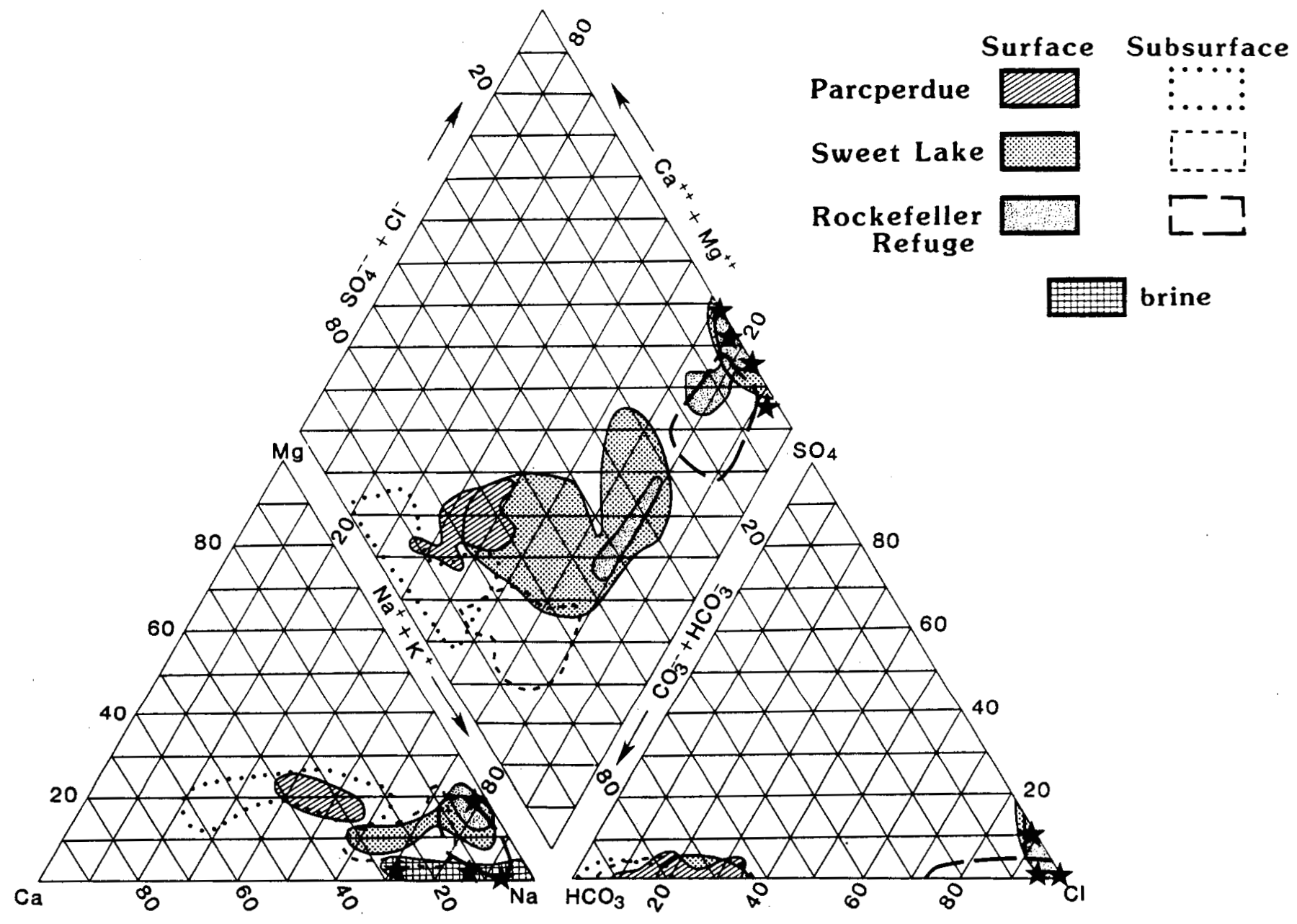

Figure 10. Ternary plot of dissolved constituents in natural waters from design geopressured-geothermal prospects in southwestern Louisiana. Stars represent the composition of seawater and subsurface brines. 
(Fig. 8) and in Sweet Lake site drainage (Fig. 6). Parcperdue surface and ground waters and Sweet Lake ground waters are highly discernible from seawater and brines in the ternary plot, indicating that contamination from either source may be detected in these waters.

Drilling fluids are highly variable depending on site geology, well mechanics, and the specific needs of the drilling program. No attempt has been made to include drilling fluids in the classification scheme. Because many major components of drilling fluids are minor components of natural waters in southwestern Louisiana, a ternary plot of natural water constituents in dril1ing fluids would be meaningless.

\section{Summary}

No single constituent should be used to detect contamination from geopressured-geothermal brines or drilling fluids in the coastal waters of southwestern Louisiana. The chemistries of natural waters are highly variable due to natural processes. The main variation is that caused by the intrusion of seawater, which is generally chemically similar to geopressured-geothermal brine. Drilling fluid contamination is also a probable cause of much variation. Many constituents of drilling fluids are present in low background concentrations or are nonexistent in natural waters. Many of these constituents can be derived individually from other sources. However, groups of related constituents more likely represent single sources of variation.

Contamination detection is primarily feasible in fresh waters in which background levels of contaminant constituents are relatively low or nonexistent. In Louisiana coastal waters and in similar waters the world over, any potential for contamination by domestic sources should be monitored with full consideration of natural processes. The mixing of relatively fresh continental runoff with seawater produces a chemical interface which is highly variable, 
depending on geologic and hydrologic characteristics. Chemical and themal properties also vary with depth, especially near the rims of basins such as the northern Gulf of Mexico. Interactions along this interface are possible from all directions. Saltwater intrusion, fluid migration from depth, and diagenesis are important processes in the coastal zone.

These processes should be, and are, all evident in water quality characterizations from geopressured-geothermal prospects in southwestern Louisiana. The variations in saltwater intrusion and fluid migration from depth are regional. Observations are concentrated at only three sites in an area of about $6000 \mathrm{mi}^{2}(15,540 \mathrm{~km} 2)$. The data base for shallow ground waters and nearsurface waters must be expanded to fully understand these processes. Diagenetic reactions which occur within the coastal interface may be qualified locally. These include clay cation exchange, precipitation, dissolution, and redox reactions. Drilling fluid contamination is also a local concern, although it is not limited to geopressured-geothermal development. This kind of contamination may be caused by any well drilling operation, such as oil and gas exploration, or ground-water production.

Not all monitored constituents may directly indicate geothermal or drilling fluid contamination, but all are useful in modeling studies which consider the chemical and physical reactions that occur during contaminant transport or other mass transfer phenomena such as diagenesis and natural fluid migration.

Various methods have been used to interpret water quality variations from geopressured-geothermal prospects in southwestern Louisiana. The most illustrative method compares concentration-versus-time curves for constituents with site activities. Ternary plots allow for a broad, general classification of natural waters in which large deviations of nomal constituents are necessary to detect contamination. 
Future contamination studies should first consider the broad, general classification of waters and then focus on concentration-versus-time curves and correlations with site activities. Statistical analyses may further enhance the interpretive efficiency of these methods by allowing for the grouping of related constituents. Other programs, designed to monitor contaminant movement closer to the source, should be implemented. Direct monitoring of contaminant plumes may be facilitated by the use of geophysical and electroresistivity methods in continuous in situ multiple-well monitoring networks. These schemes could provide a base for the modeling of chemical and physical mass transport in Louisiana coastal waters.

\section{References}

Bebout, D. G., Z. Bassiouni, D. R. Carver, C. G. Groat, A. E. Johnson, Jr., and F. M. Wrighton, 1983, Technical support for geopressured-geothermal well activities in Louisiana: Annual report for the period 1 November 1981 to 31 October 1982: La. State Univ., Office of Research, La. Geol. Survey, DOE/NV/10174-2, p. 391-93.

Grim, R. E., 1968, Clay mineralogy: McGraw-Hill Internat. Series in the Earth and Planetary Sciences, $596 \mathrm{p}$.

Groat, C. G., V. R. Van Sickle, D. Trahan, and L. T. Gorman, 1982, Environmental monitoring, in D. G. Bebout, Z. Bassiouni, D. R. Carver, C. G. Groat, R. H. Pilger, Jr., and F. M. Wrighton, 1982, Technical support for geopressured-geothermal well activities in Louisiana: Annual report for the period November 1, 1980, to October 31, 1981: La. State Univ., La. Geol. Survey, DOE/NV/10174-1, p. 243-377.

Livingstone, D. A., 1963, Data of geochemistry (6th ed.): U.S. Geo1. Survey, Prof. Paper 440-G, p. 41.

NL Baroid, 1983, Drilling mud handbook: NL Industries, Inc., 215 p. 
Piper, A. M., 1944, A graphic procedure in the geochemical interpretation of water analyses: Transactions of the American Geophysical Union, vol. 25, p. 914-928.

Potter, P. E., J. B. Maynard and W. A. Pryor, 1980, Sedimentology of shale: Springer-Verlag, New York, 306 p.

Rankama, K., and Th. G. Sahama, 1950, Geochemistry: Univ. Chicago Press, p. 286-93.

Trahan, D. B., 1984, water quality monitoring, in C. G. Groat, Technical support for geopressured-geothermal well activities in Louisiana: Annual report for the period 1 November 1982 to 31 October 1983: La. State Univ., Office for Research, La. Geol. Survey, D0E/NV/10174-4, p. 1-12. Wrighton, F. M., D. G. Bebout, D. R. Carver, C. G. Groat, and A. E. Johnson, Jr., 1981, Technical support for geopressured-geothermal well activities in Louisiana: Final report for the period September 27, 1978 to December 31, 1980: La. State Univ., Advanced Studies and Research, Energy Programs Office, DOE/ET/27160, p. 53-64. 


\section{APPENDIX A}

PARCPERDUE

CONCENTRATION VS. TIME CURVES

FOR DISSOLVED CONSTITUENTS

AND PHYSICAL PARAMETERS

IN NATURAL WATERS

SURFACE WATERS

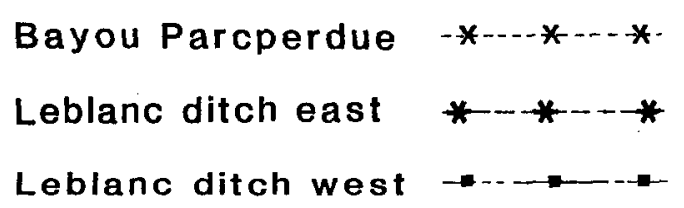

GROUND WATERS

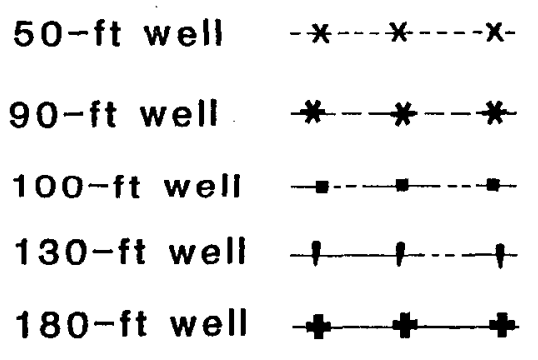
NA - No Activity
D - Drilling
P - Production 


\section{SURFACE WATERS}
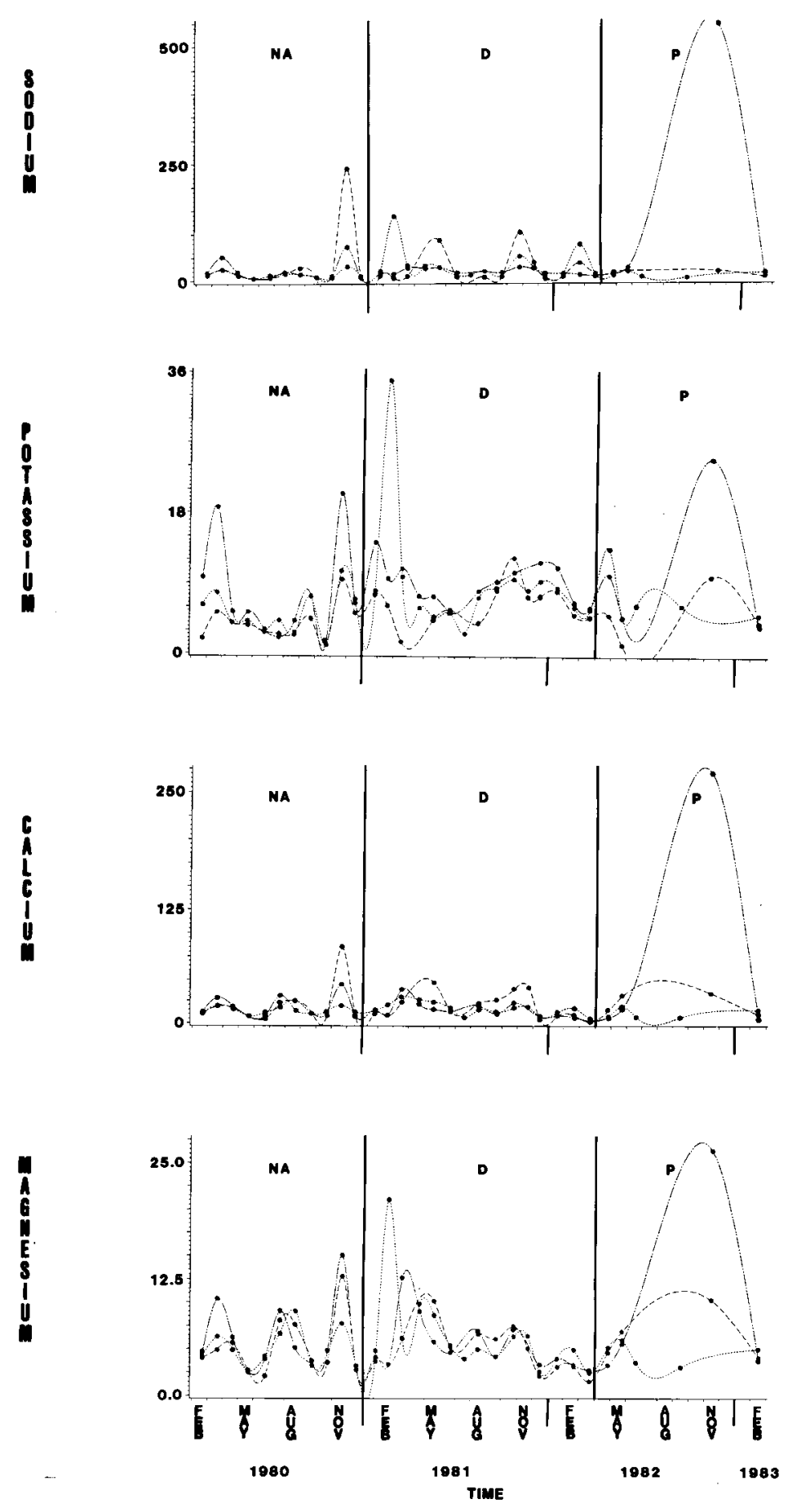

GROUND WATERS
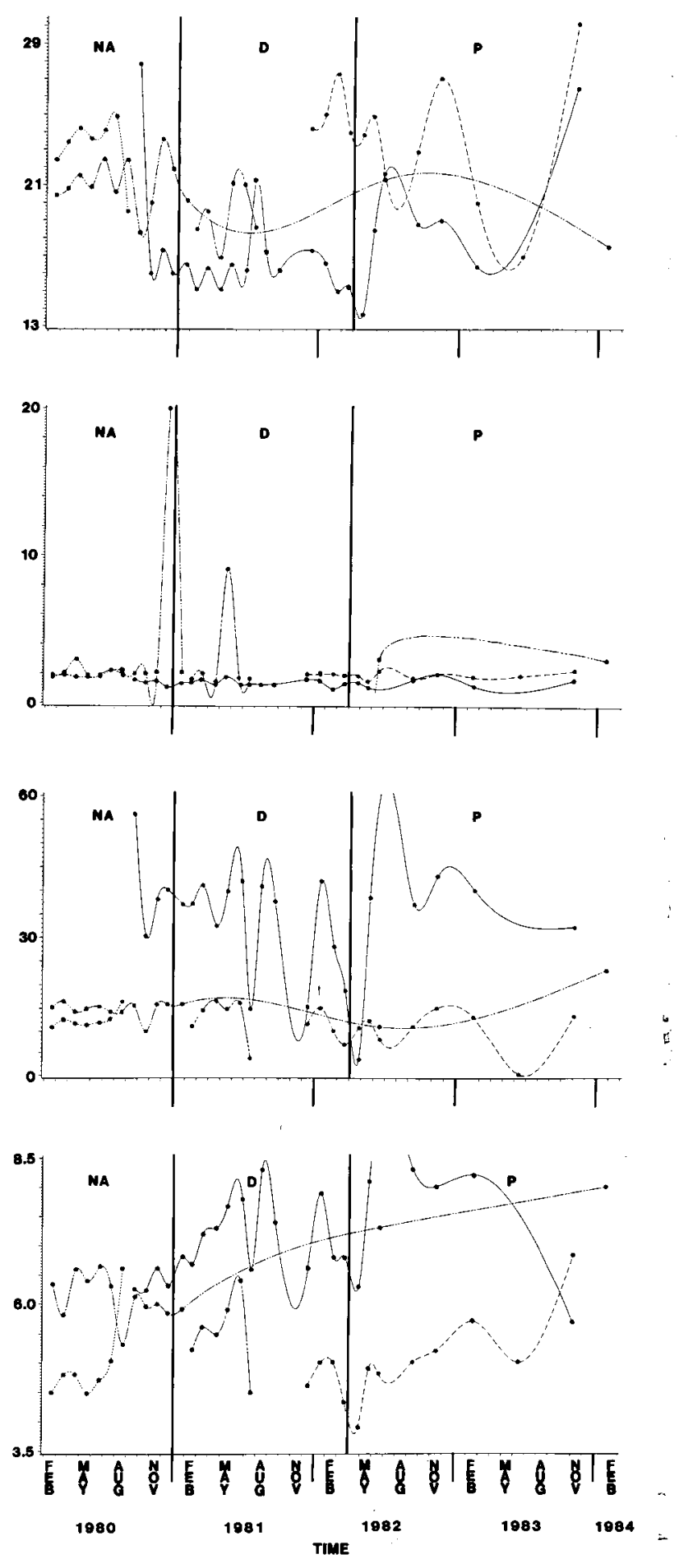

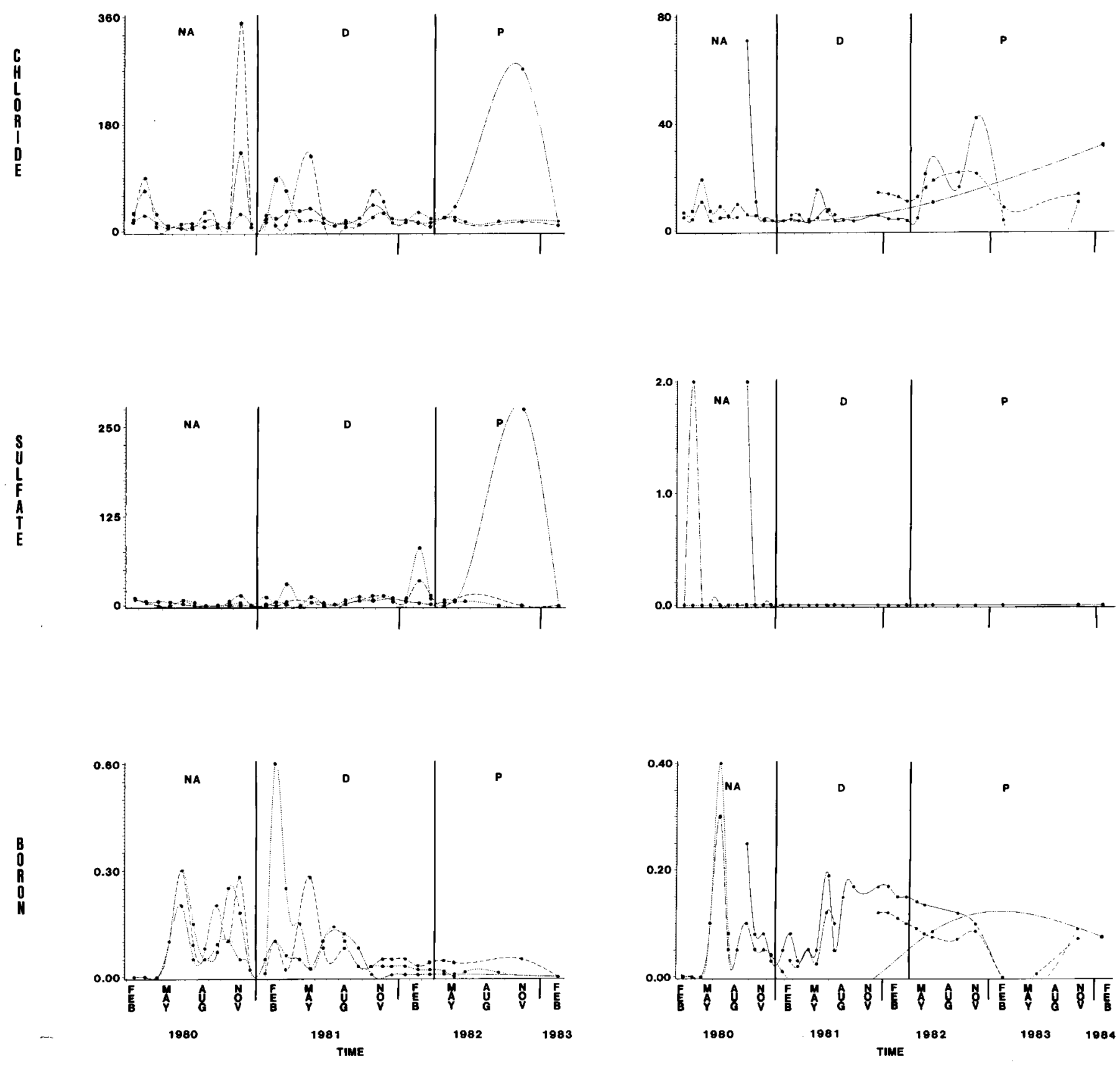


\section{SURFACE WATERS}

0
1
5
5
0
$\mathbf{1}$
$\mathbf{E}$
$\mathbf{D}$
0
$\mathbf{X}$
$\mathbf{y}$
6
$\mathbf{E}$

1
0
0
1
1
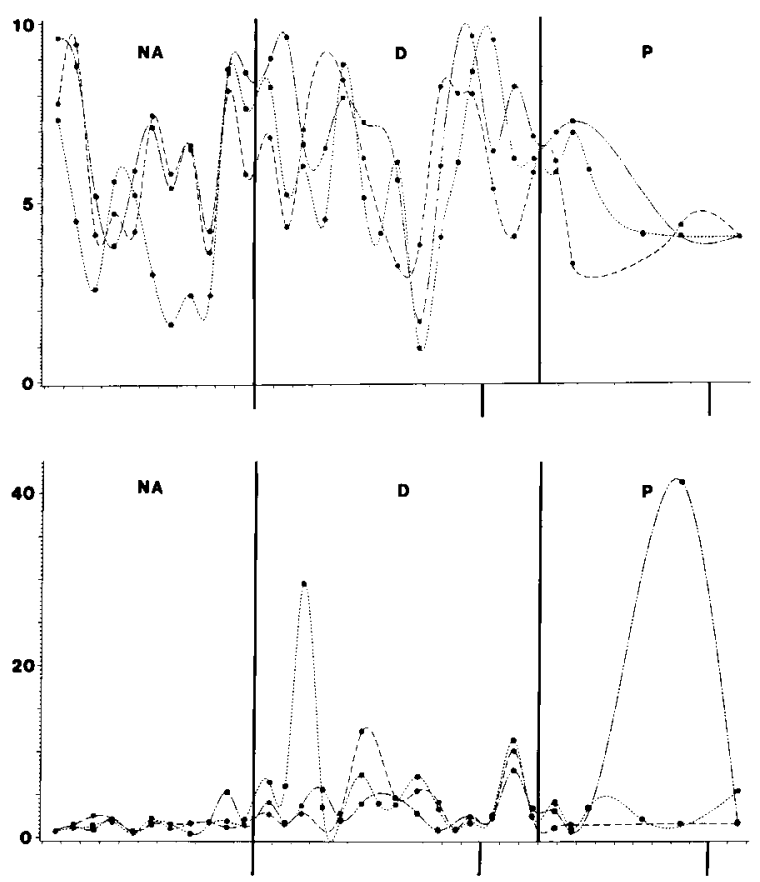

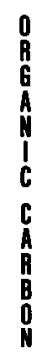
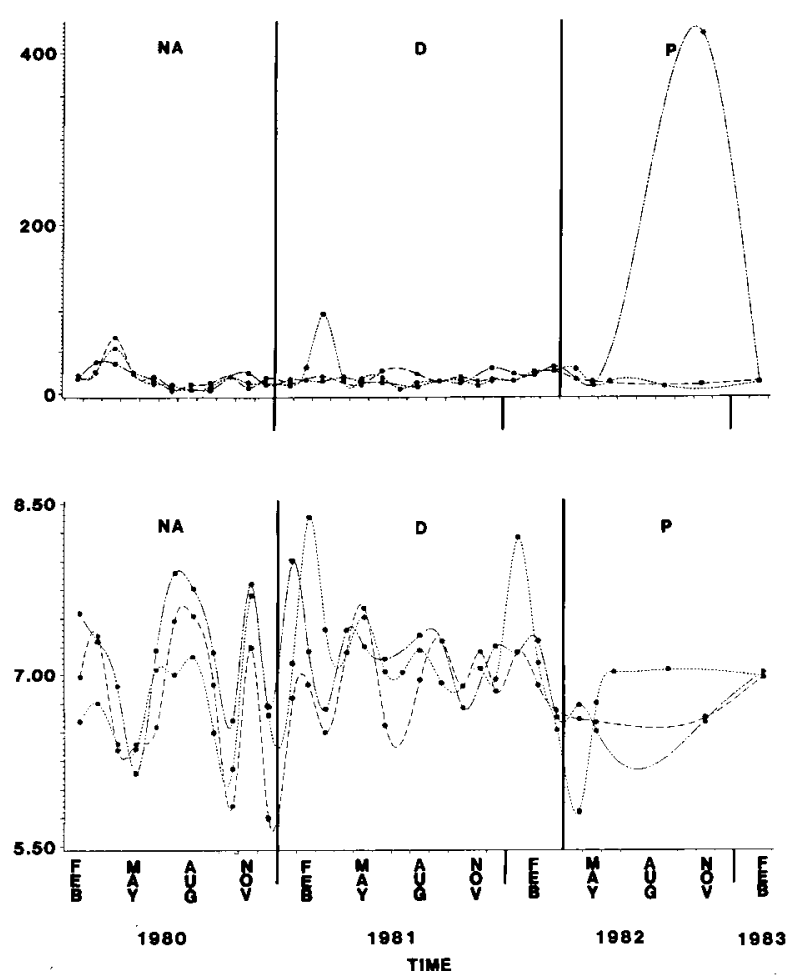

GROUND WATERS
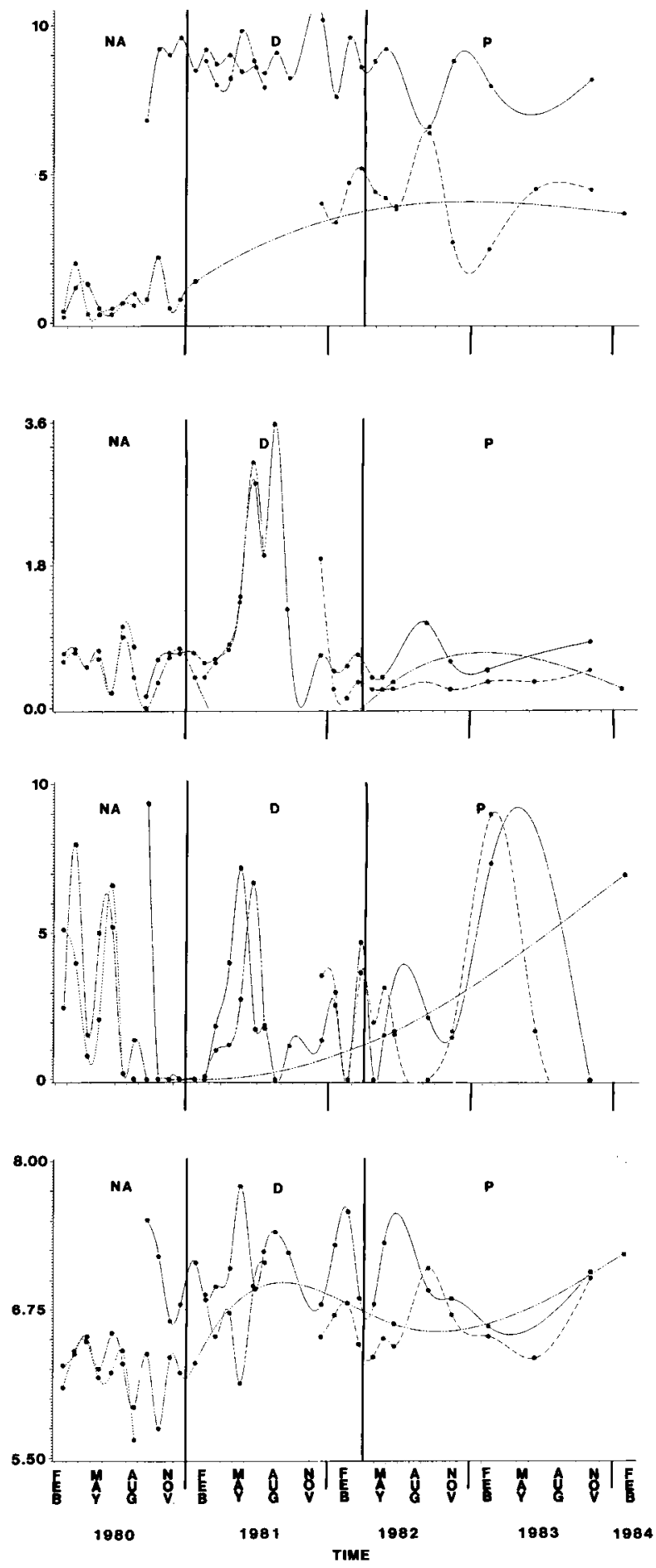

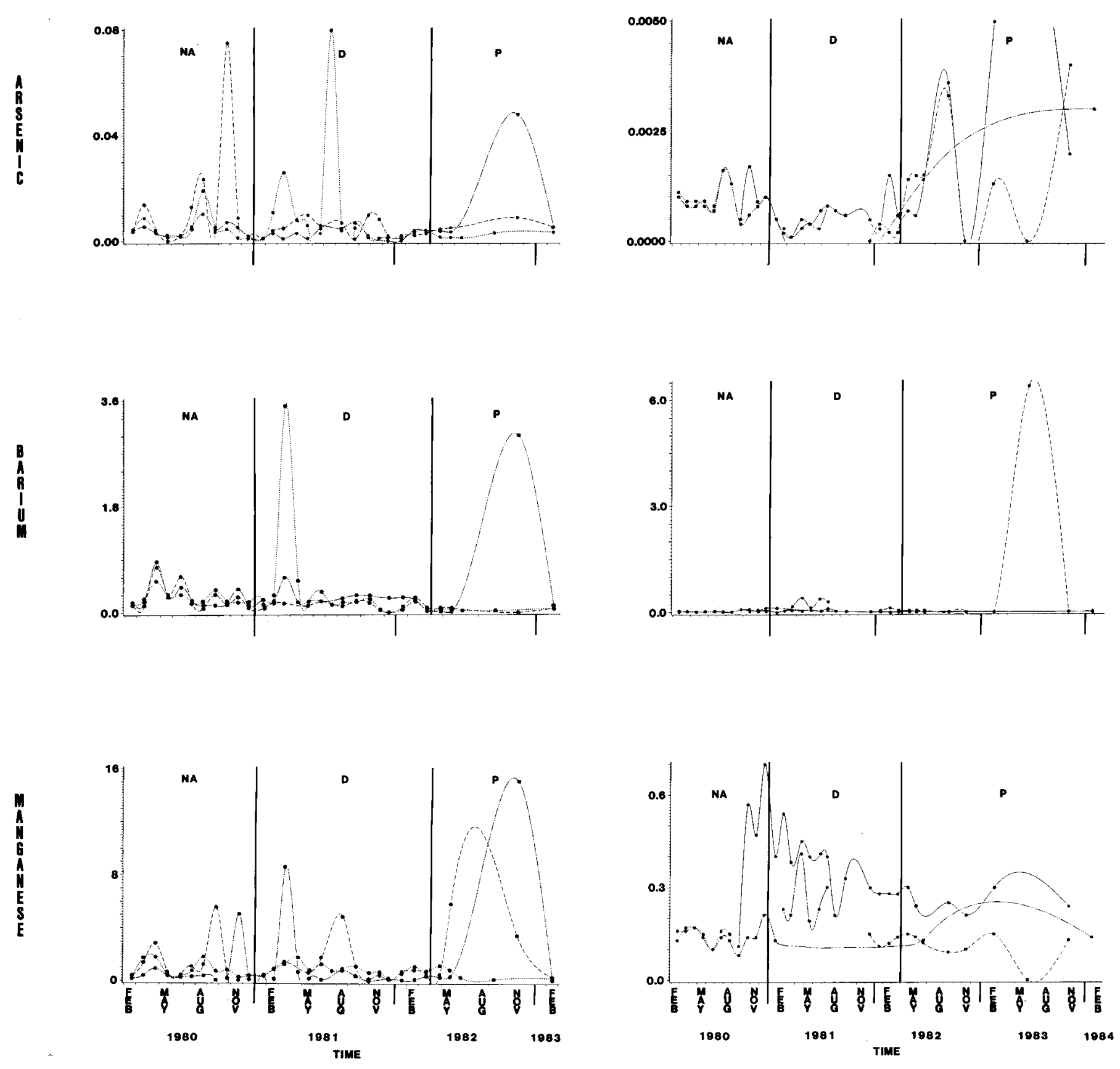
SURFACE WATERS
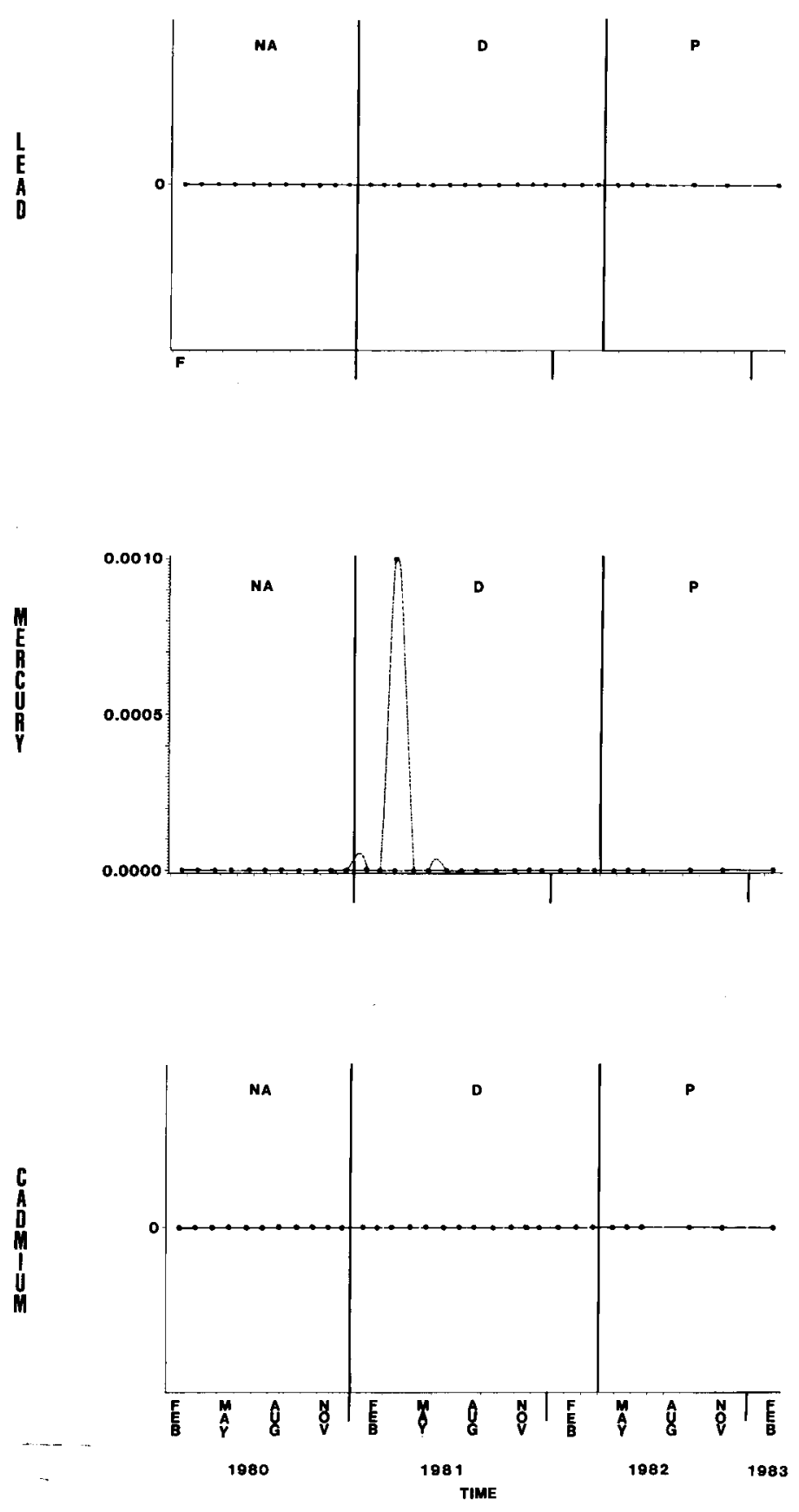

GROUND WATERS
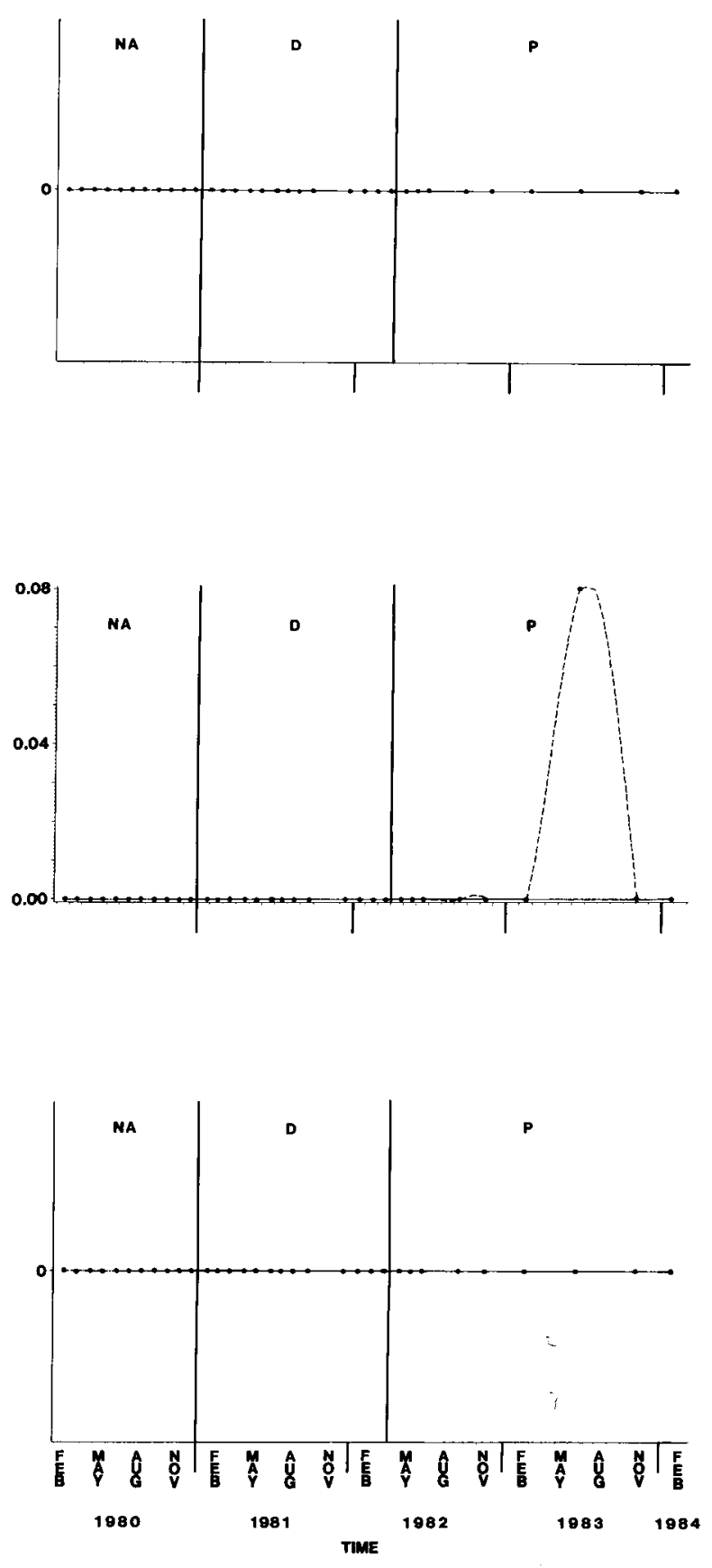


\section{SURFACE WATERS}
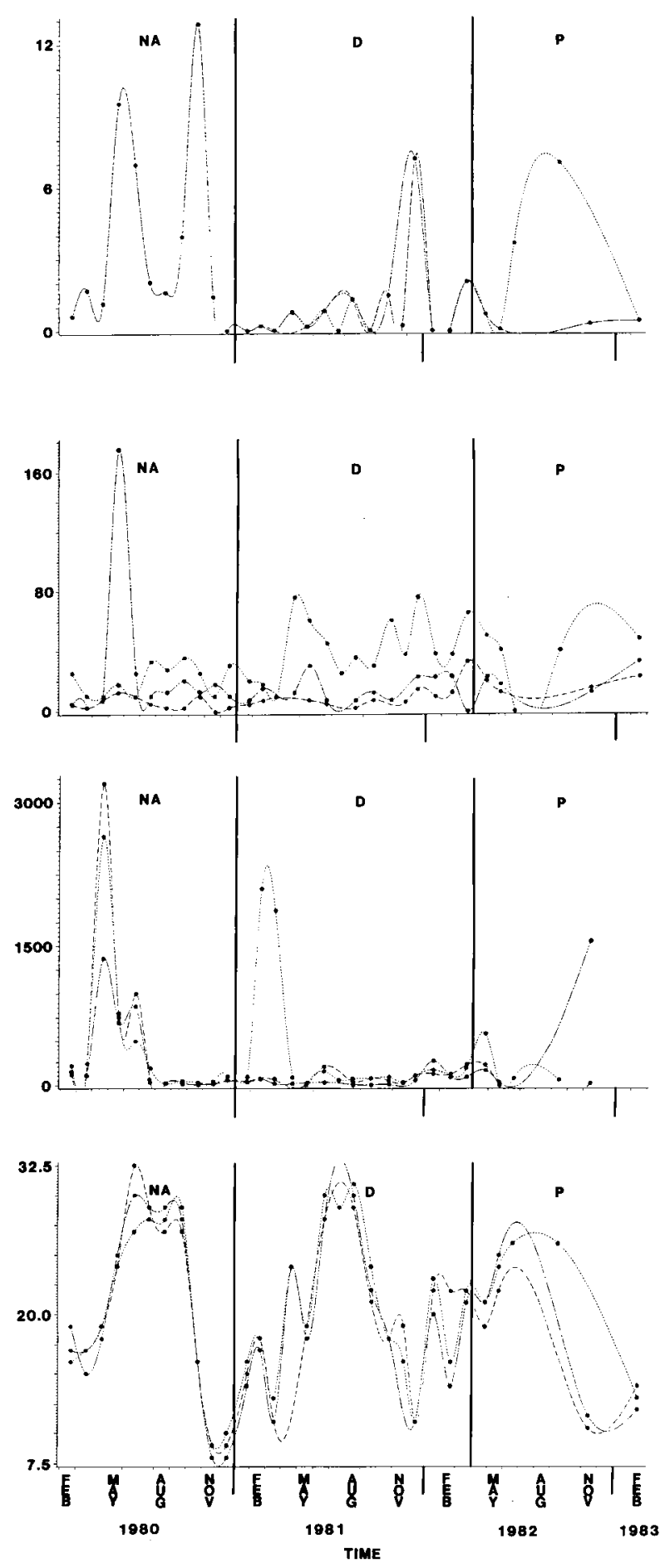

GROUND WATERS
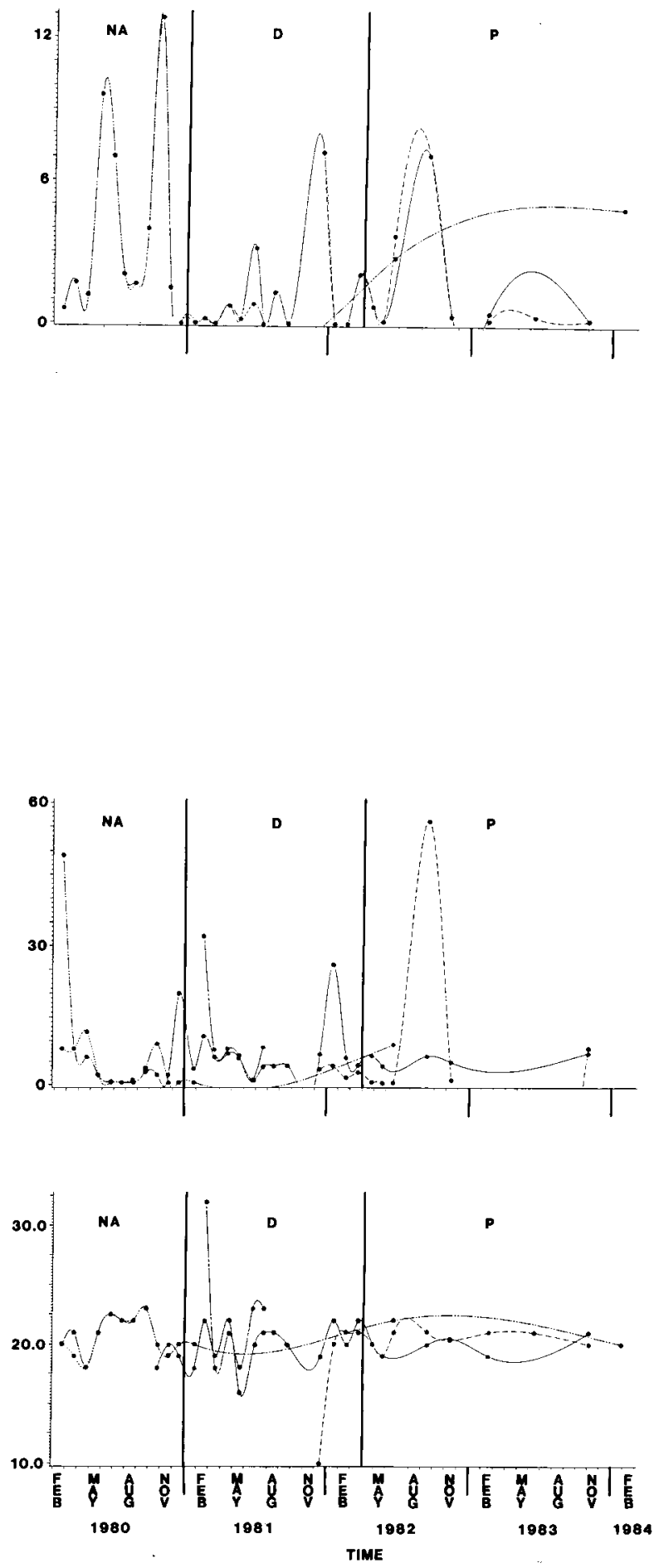


\title{
APPENDIX B
}

\author{
SWEET LAKE \\ CONCENTRATION VS. TIME CURVES \\ FOR DISSOLVED CONSTITUENTS \\ AND PHYSICAL PARAMETERS \\ IN NATURAL WATERS
}

SURFACE WATERS

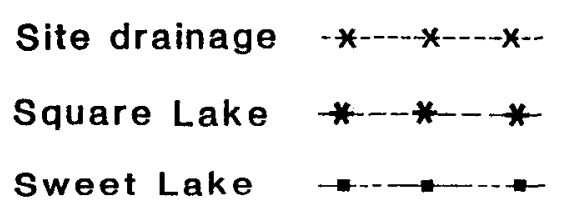

\section{GROUND WATERS}

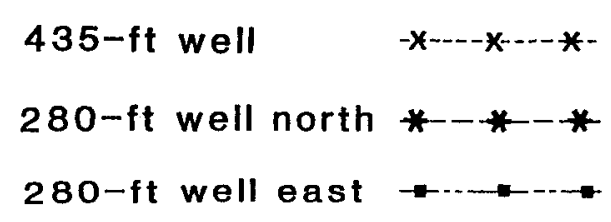

$$
\begin{aligned}
& \text { NA - No Activity } \\
& \text { D - Drilling } \\
& \text { P - Production } \\
& \text { C - Cleanup }
\end{aligned}
$$




\section{SURFACE WATERS}
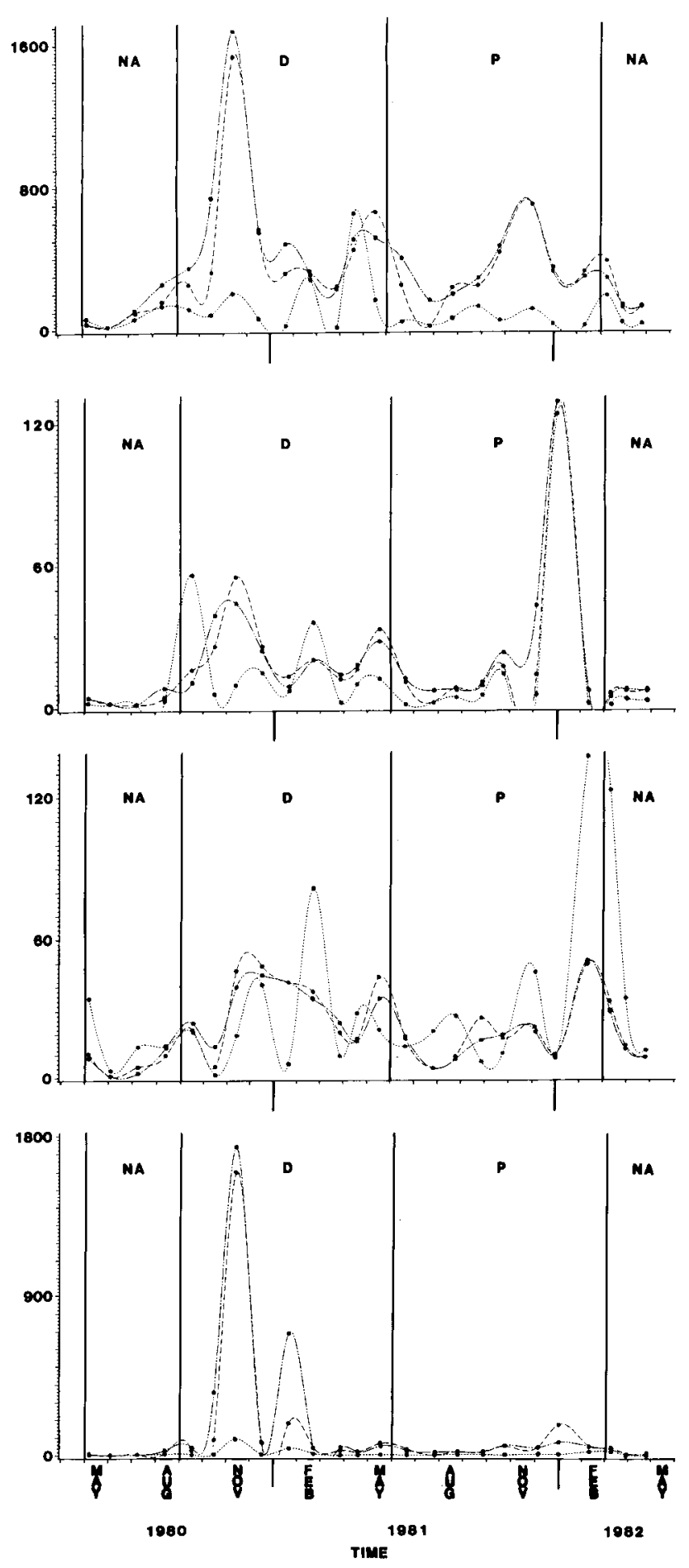

GROUND WATERS
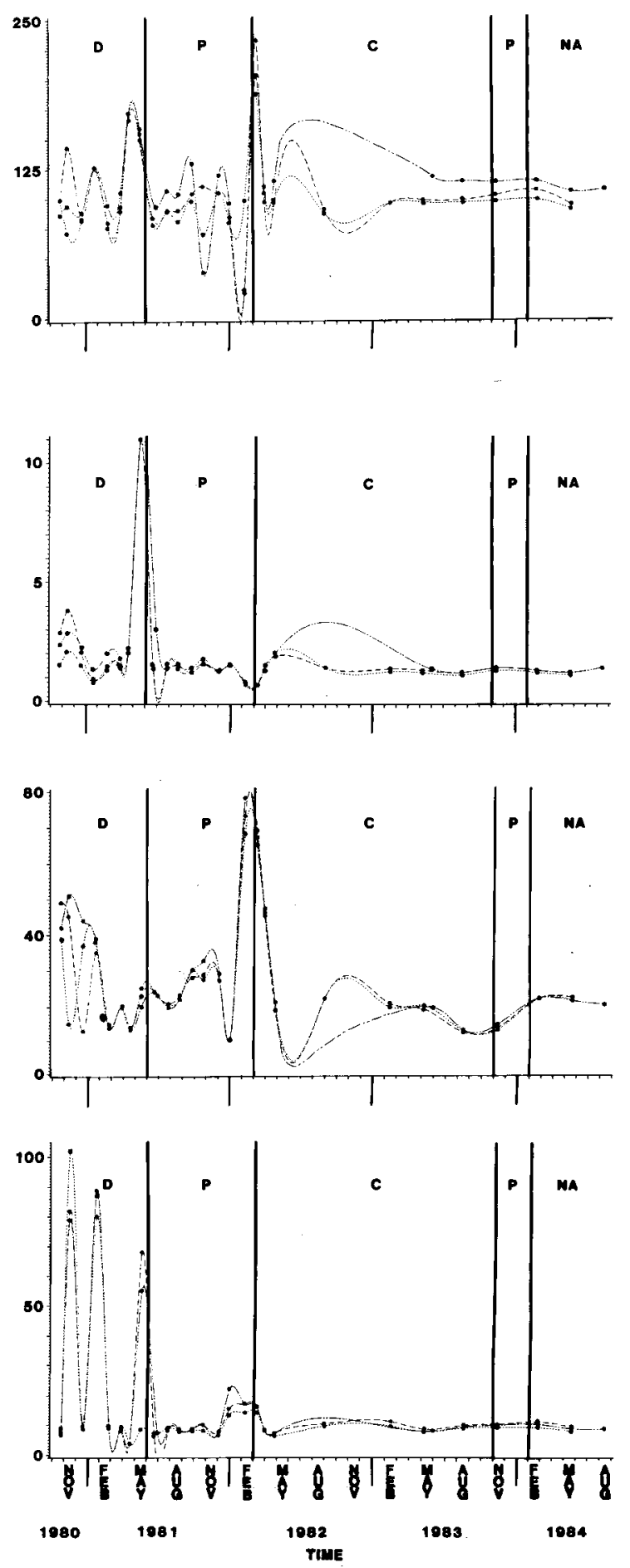

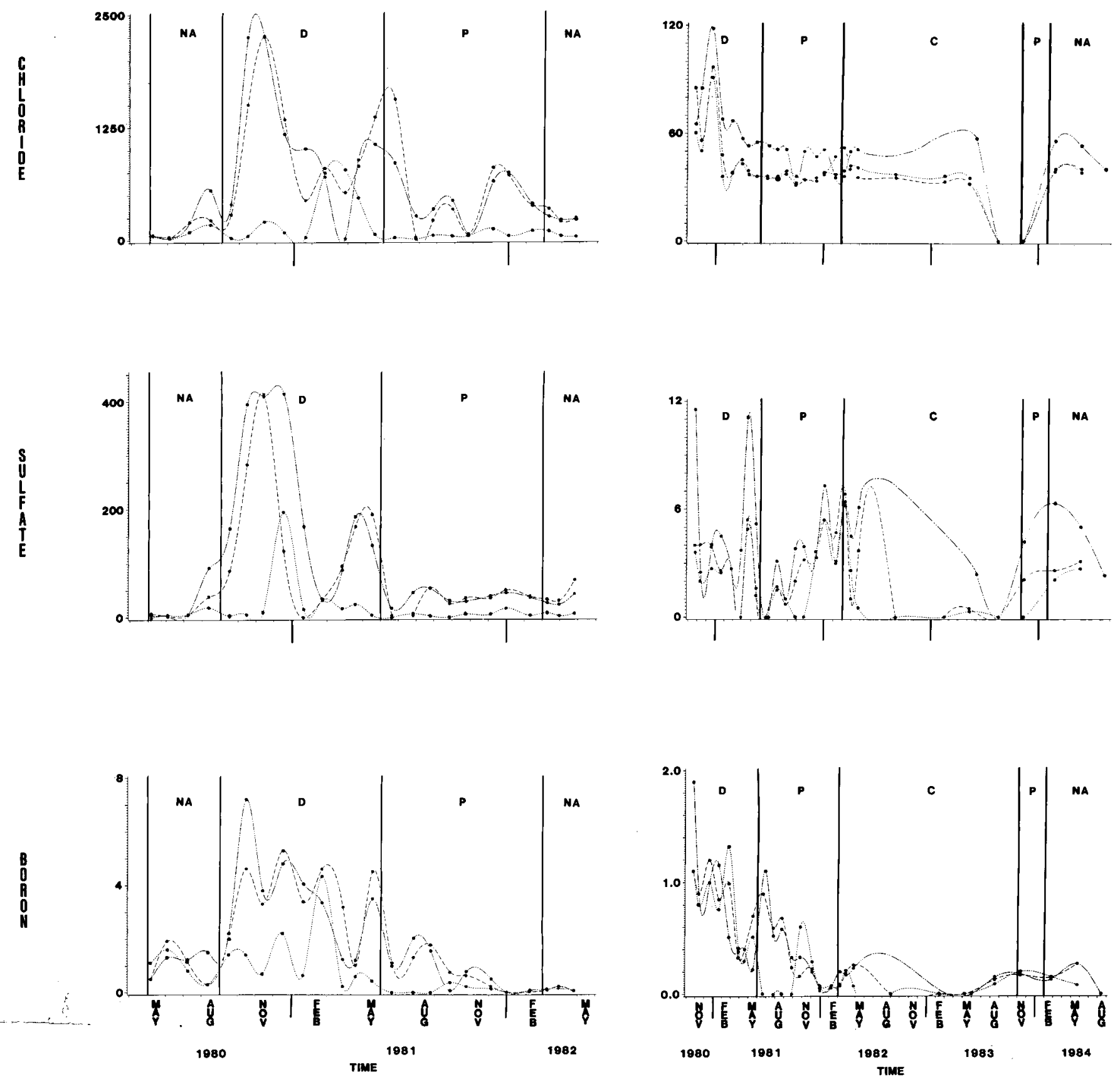

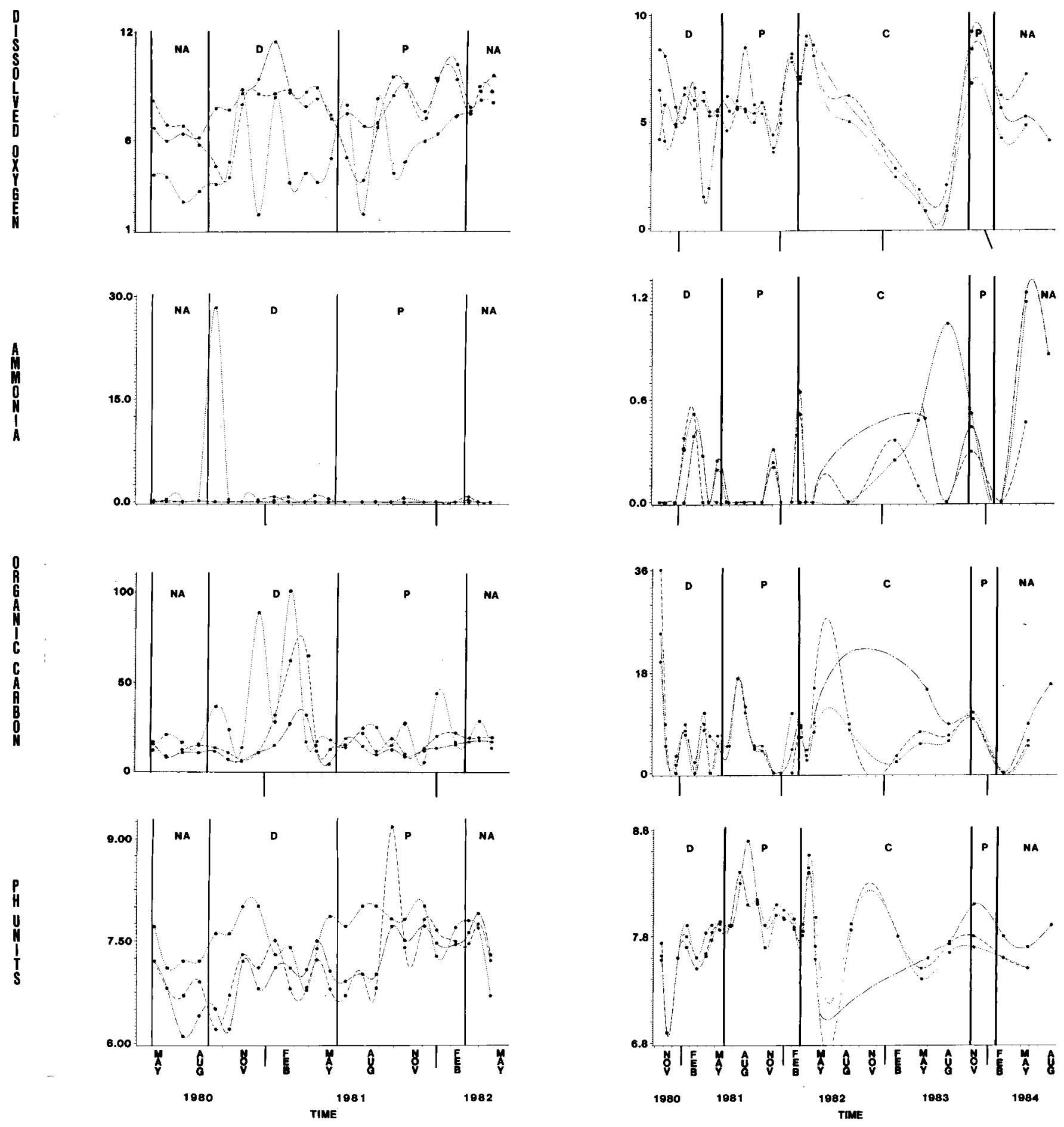

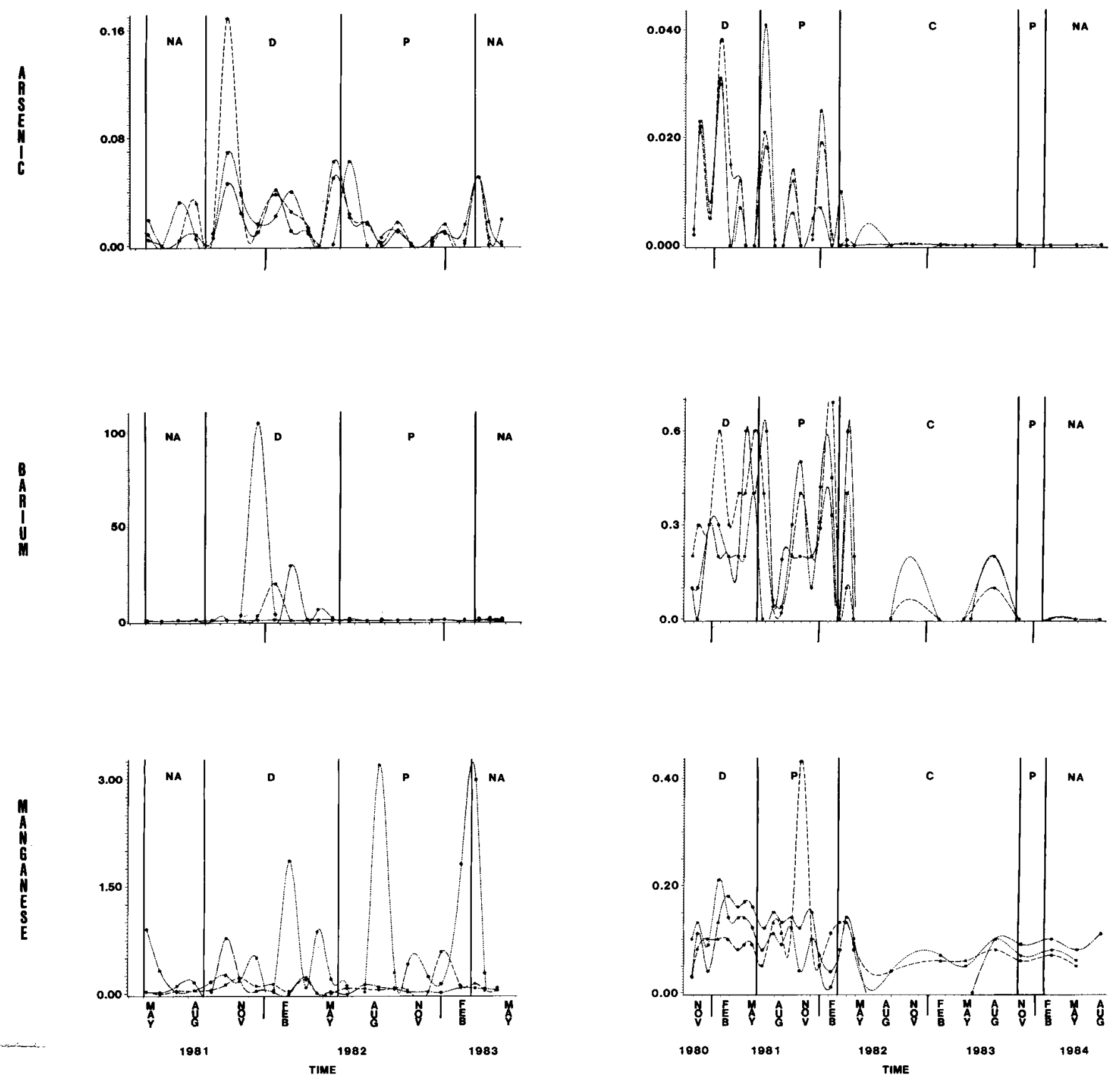


\section{SURFACE WATERS}
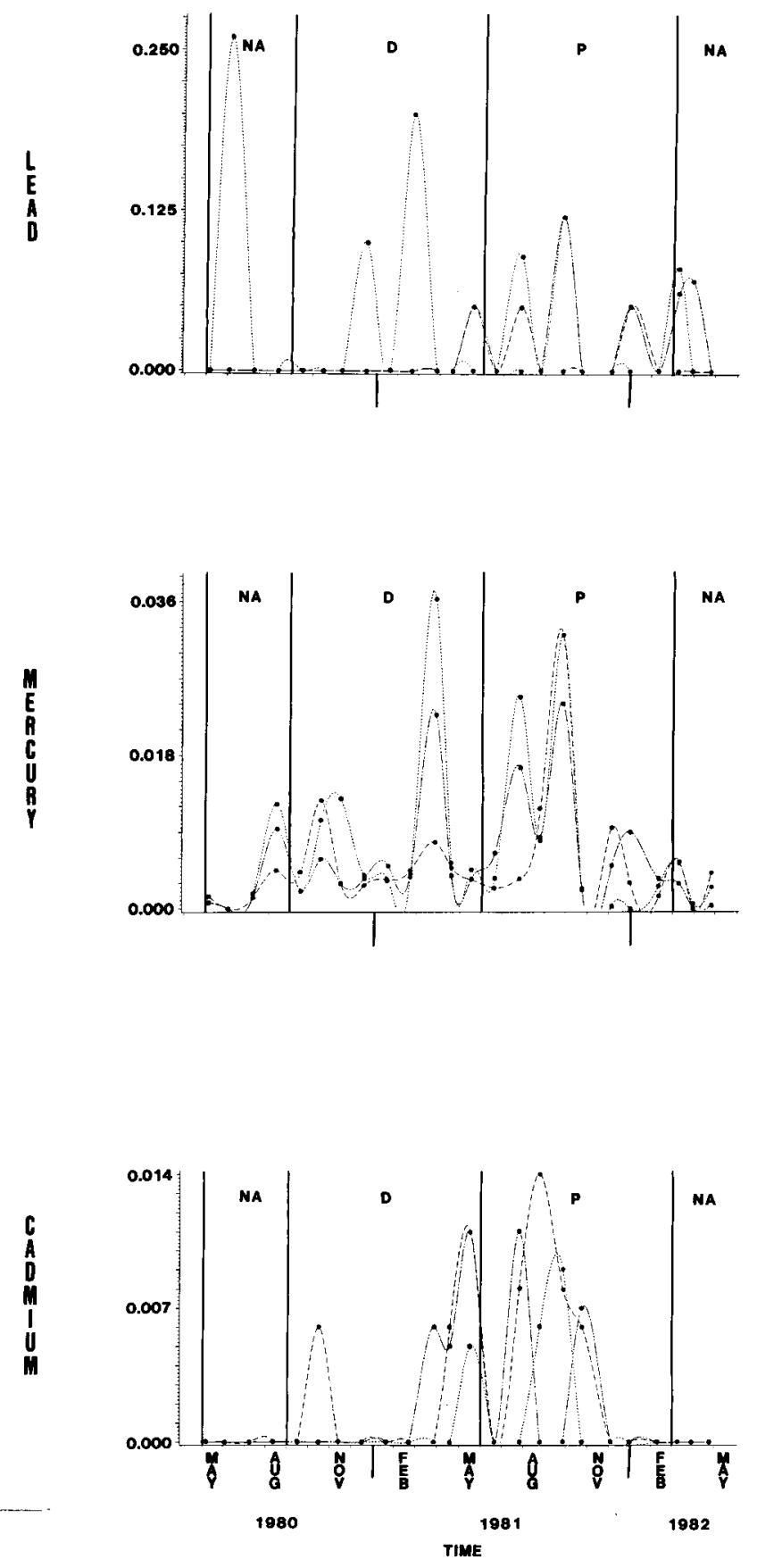

\section{GROUND WATERS}
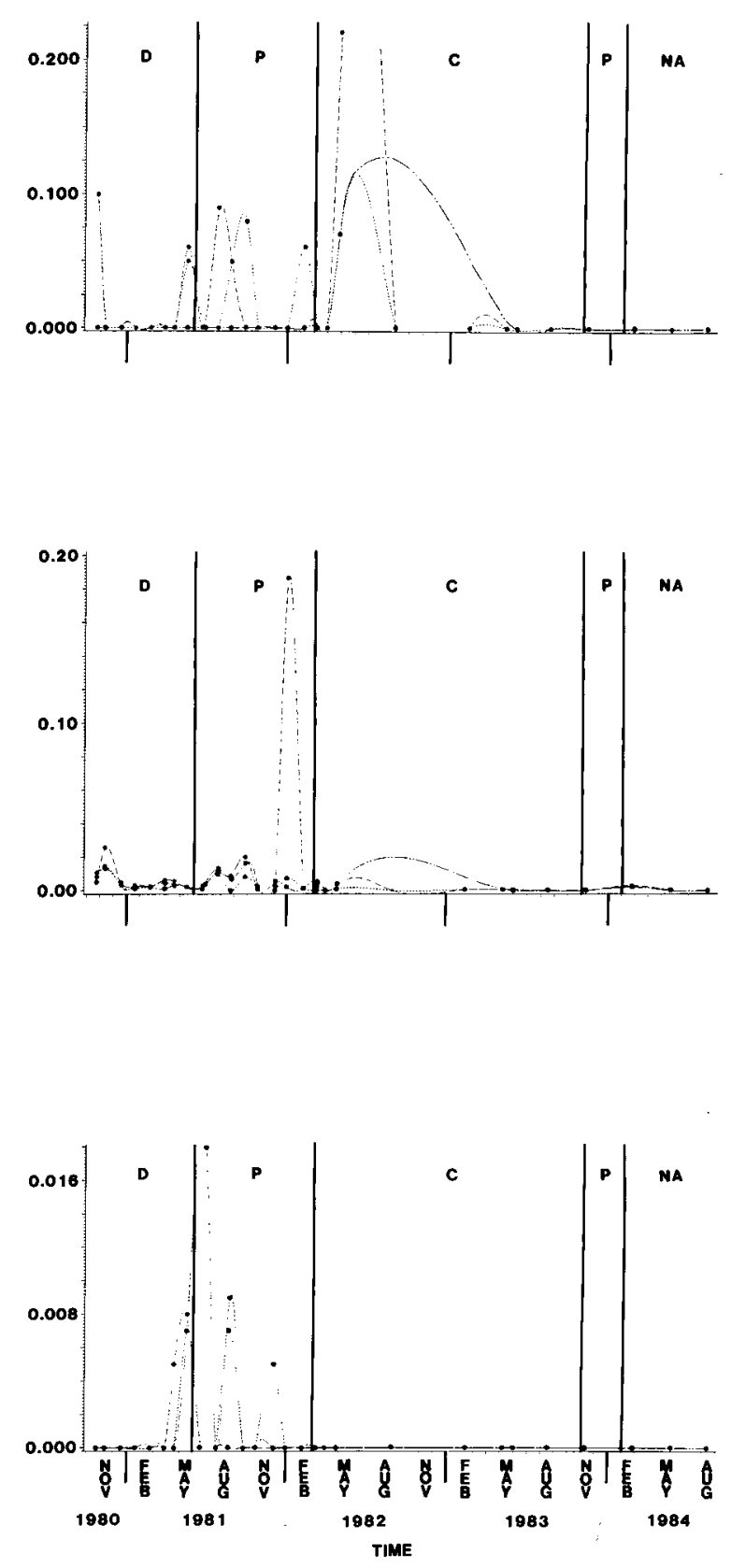


\section{SURFACE WATERS}
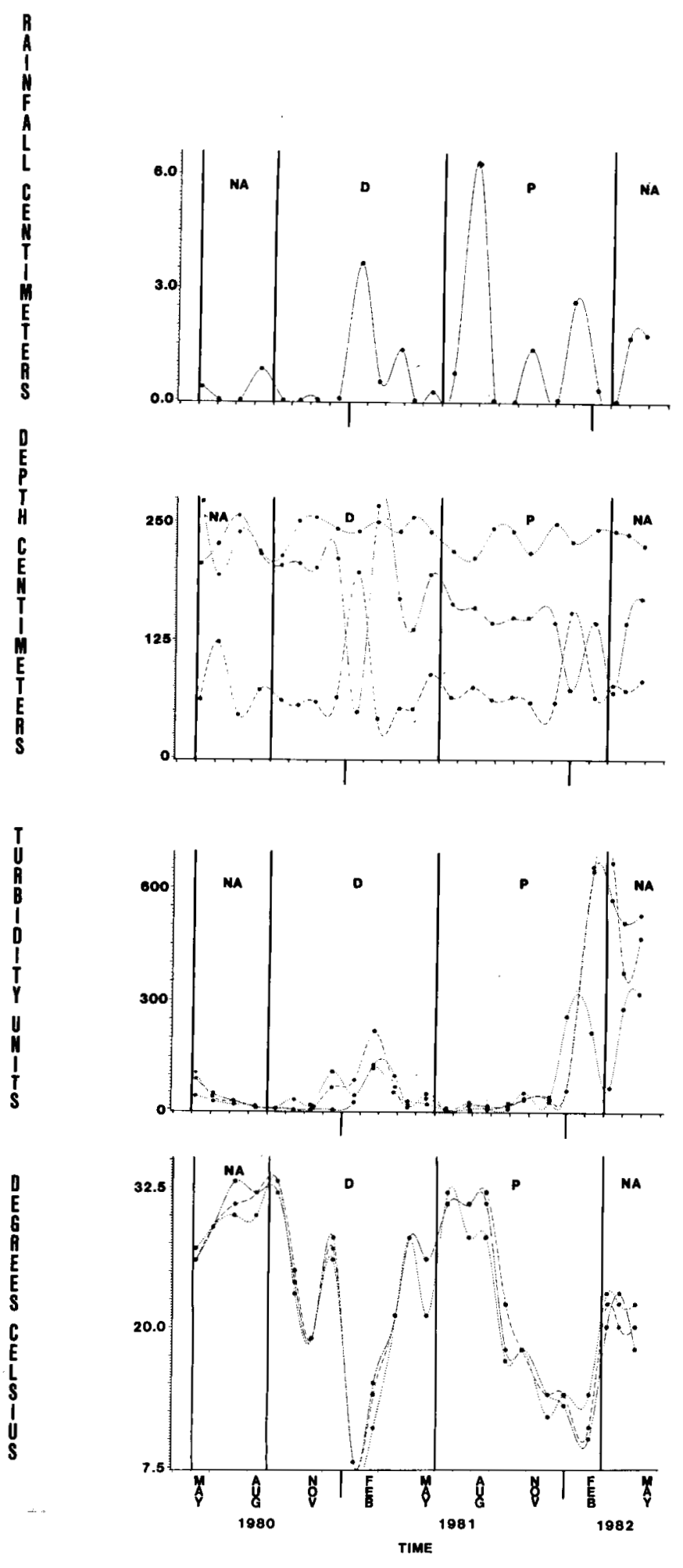

\section{GROUND WATERS}
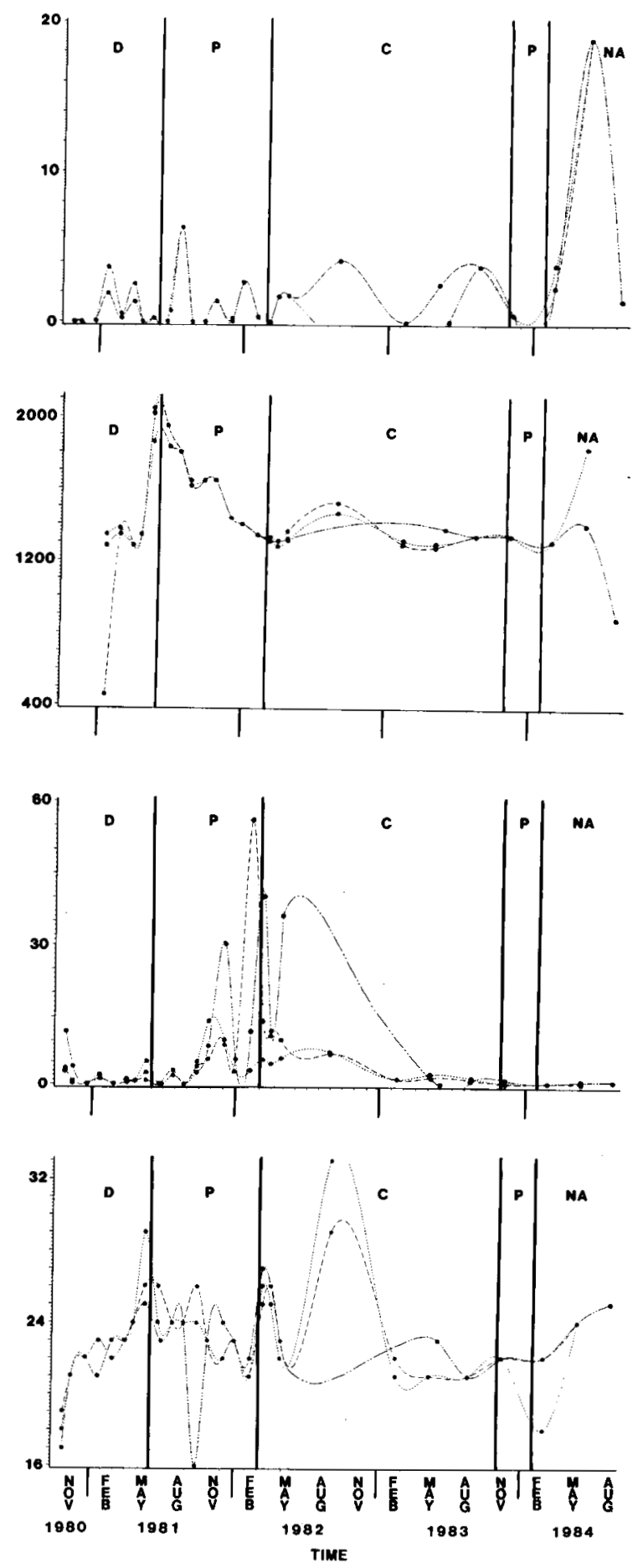


\section{ROCKEFELLER REFUGE}

CONGENTRATION VS. TIME CURVES

FOR DISSOLVED CONSTITUENTS

AND PHYSICAL PARAMETERS

IN NATURAL WATERS

SURFACE WATERS

Impoundment

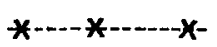

Impoundment outflow

Hog Bayou (tidal)
GROUND WATERS

310-ft well -x----x----*

660-ft well *--*---*

D - Drilling

P - Production 
x

SURFACE WATERS
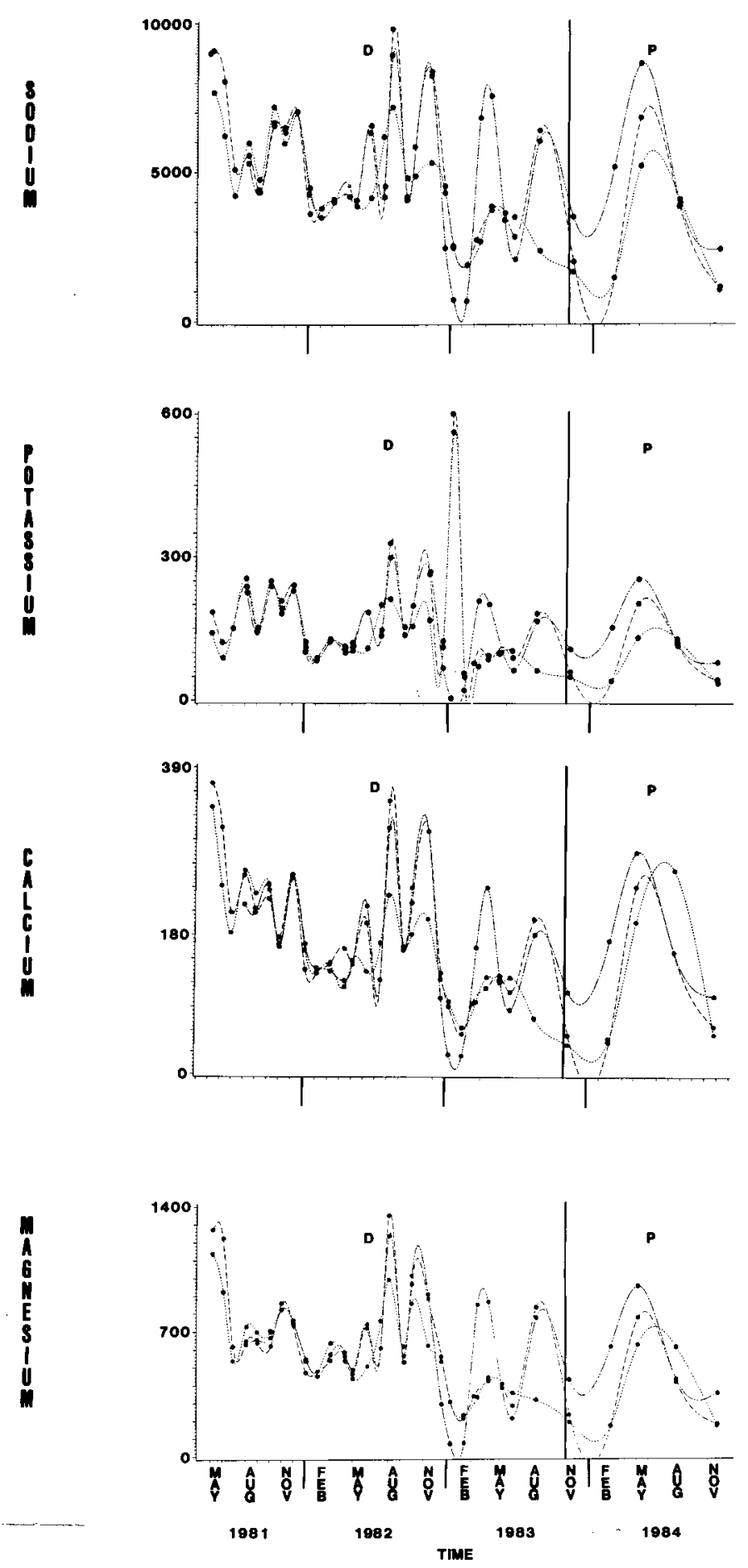

GROUND WATERS
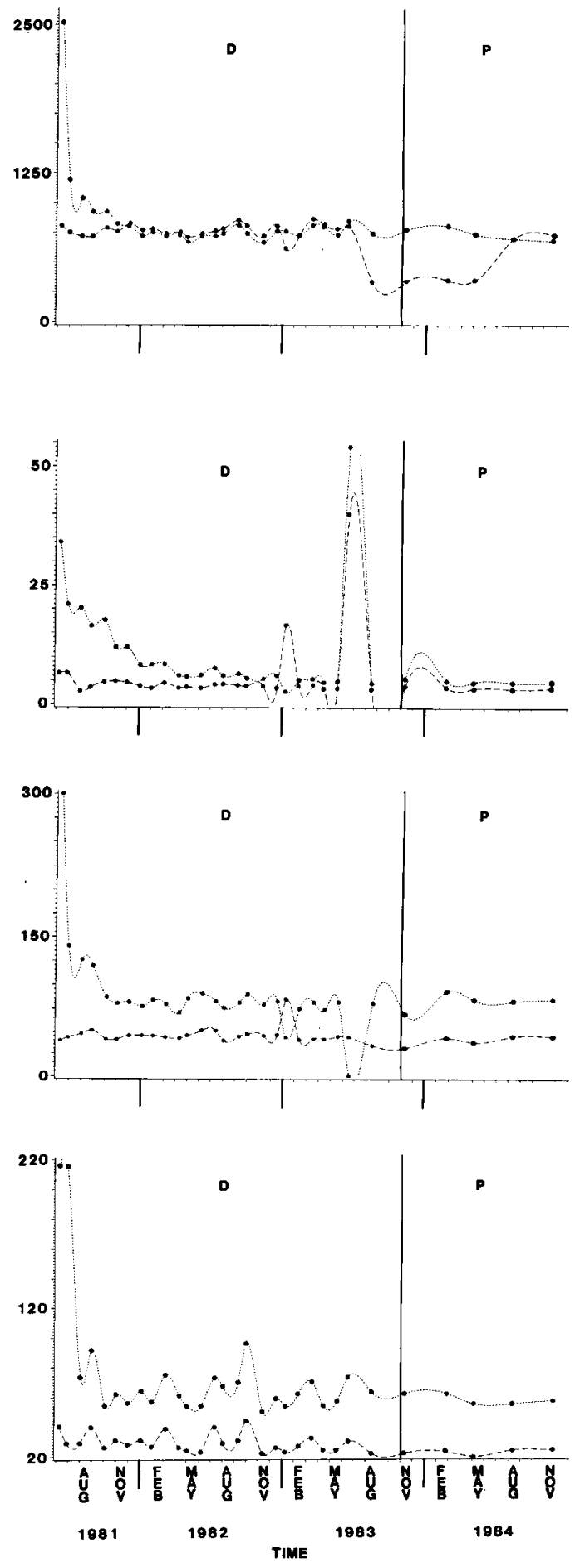

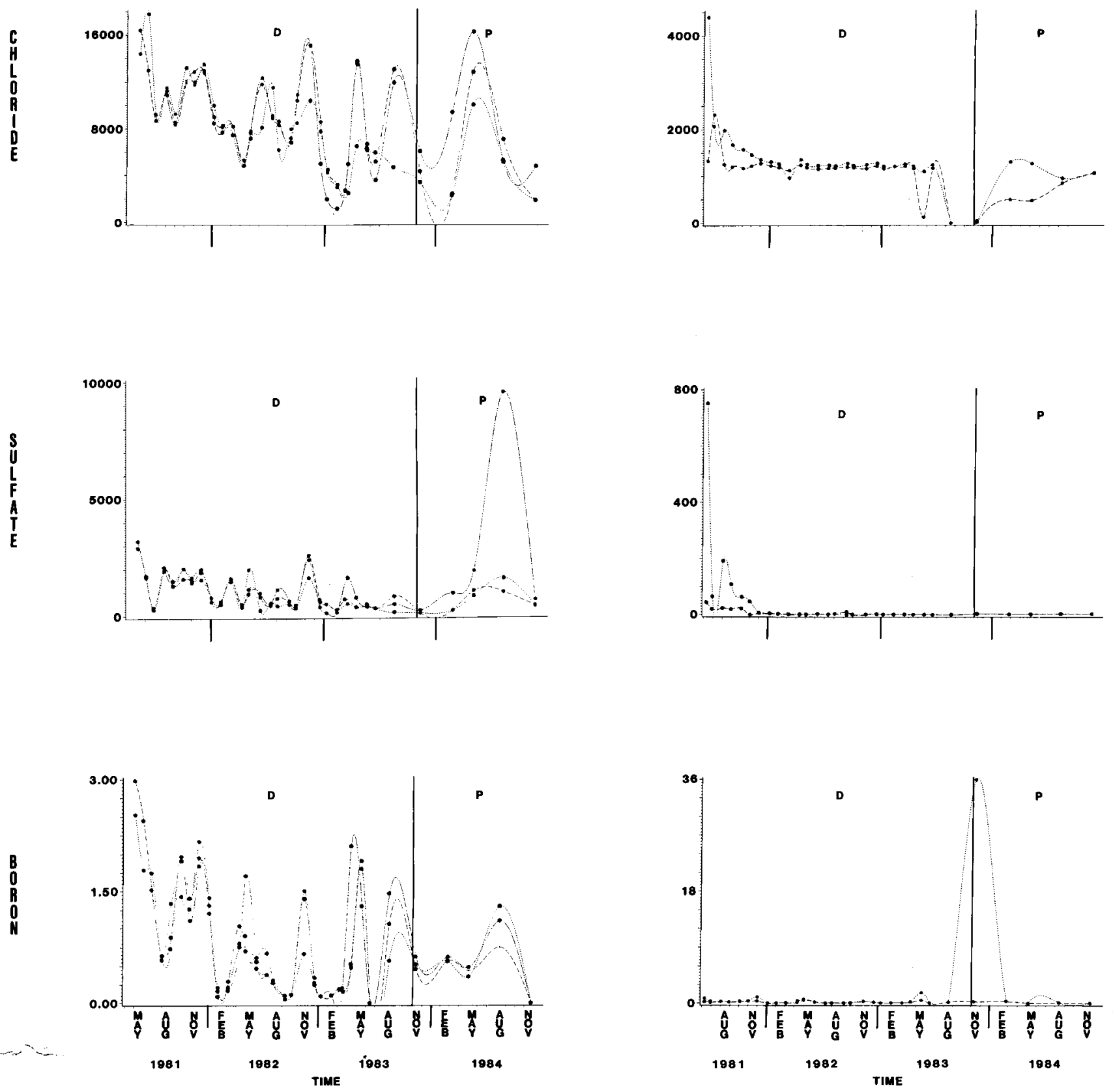

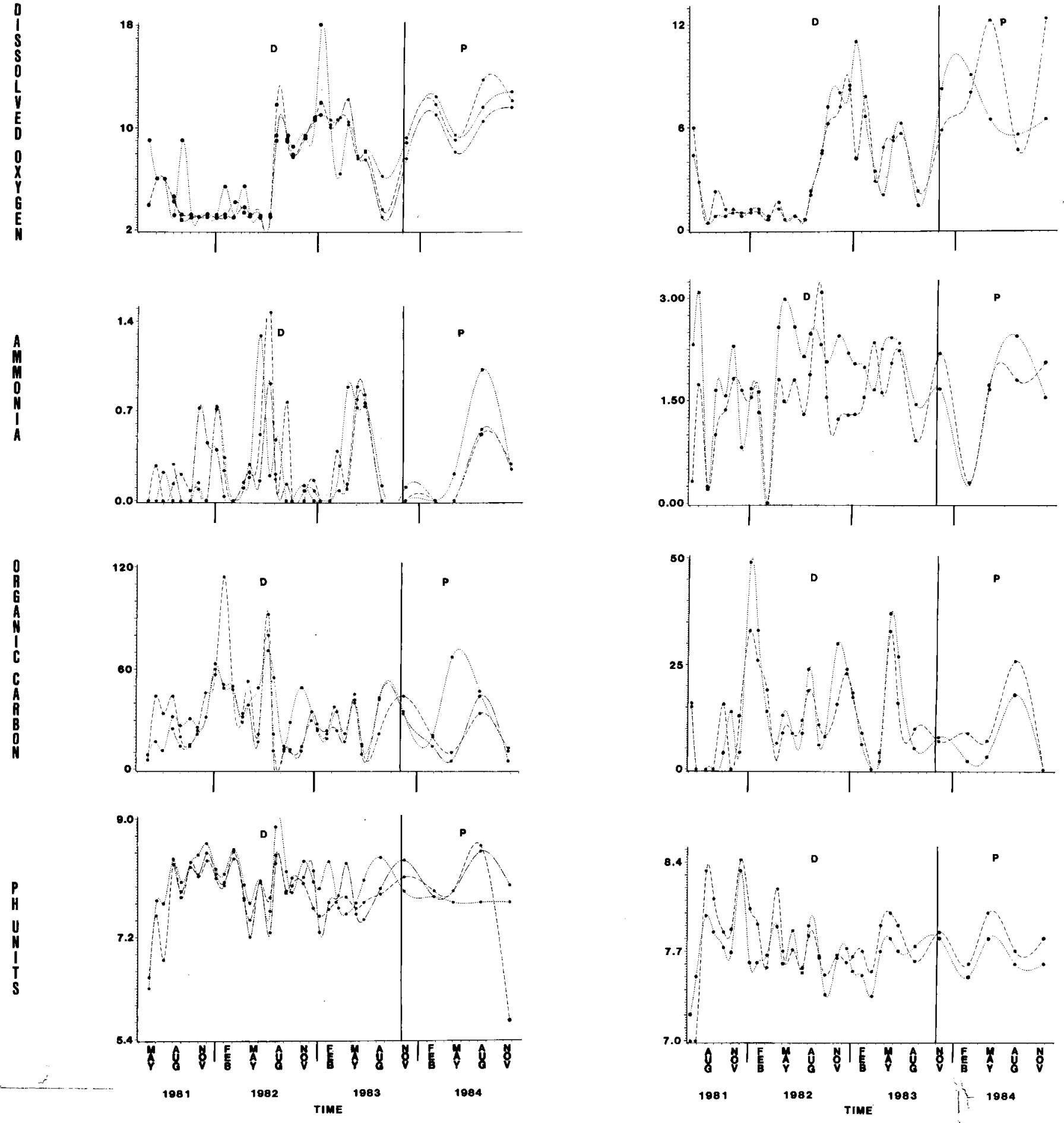


\section{SURFACE WATERS}

\section{GROUND WATERS}
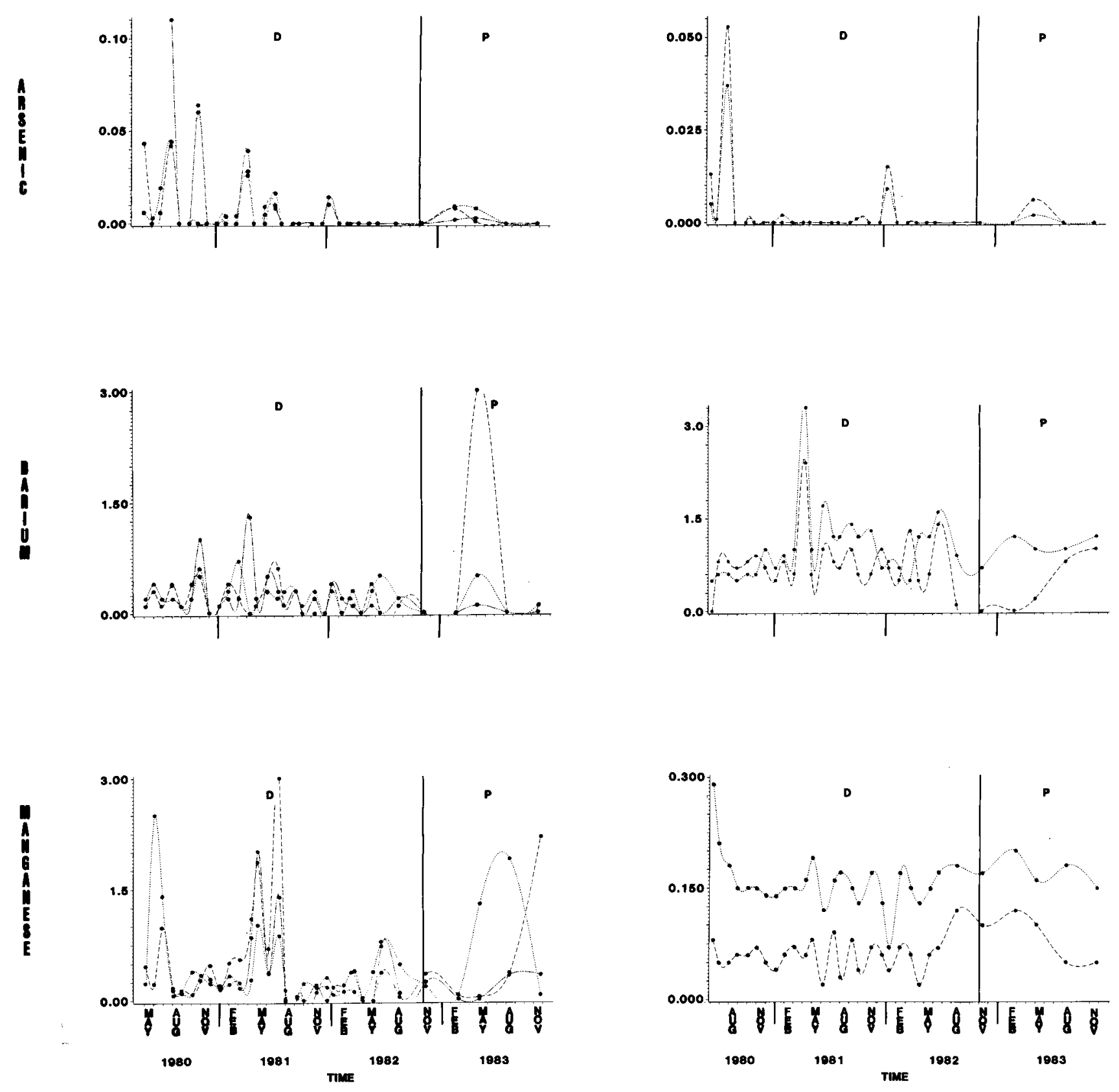


\section{SURFACE WATERS}
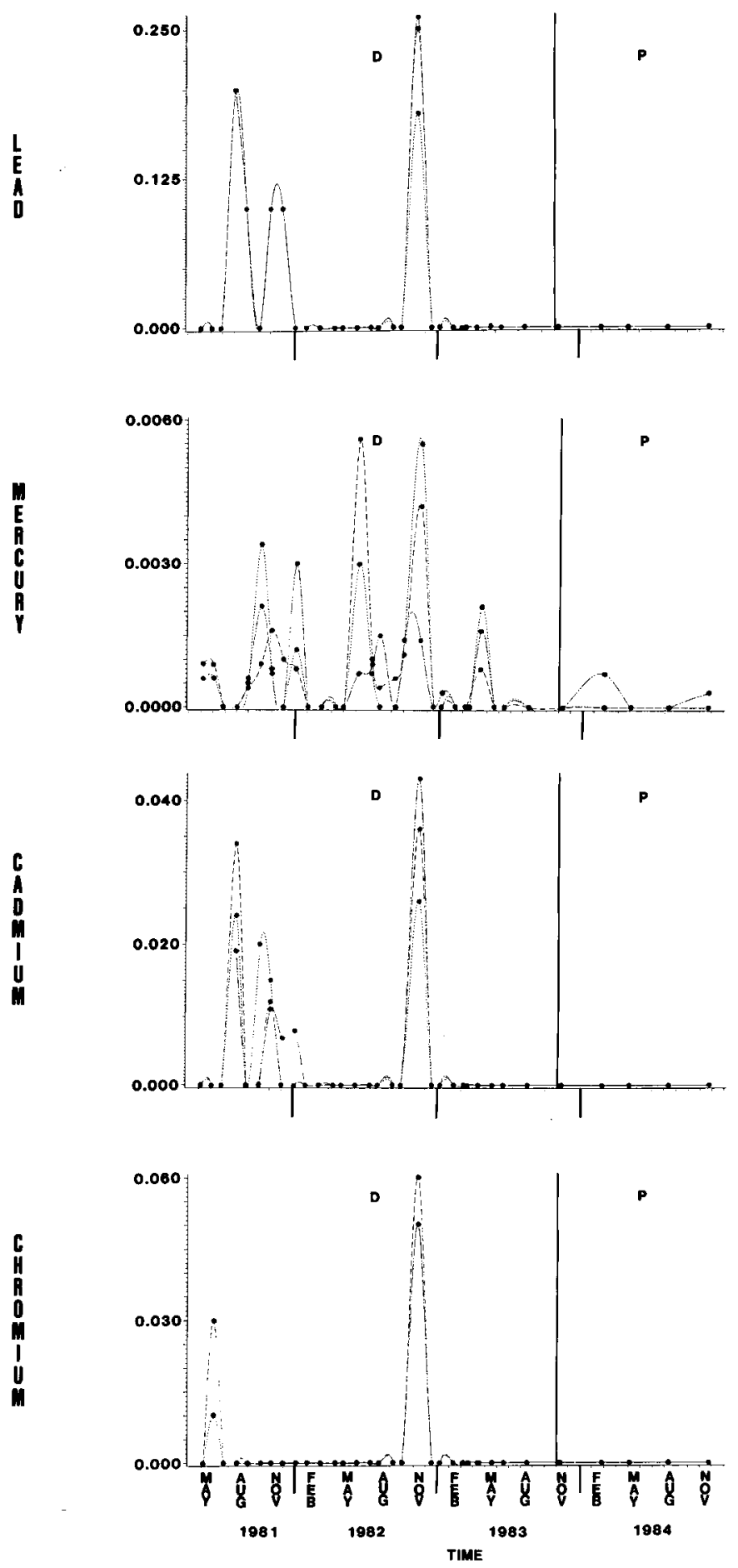

\section{GROUND WATERS}
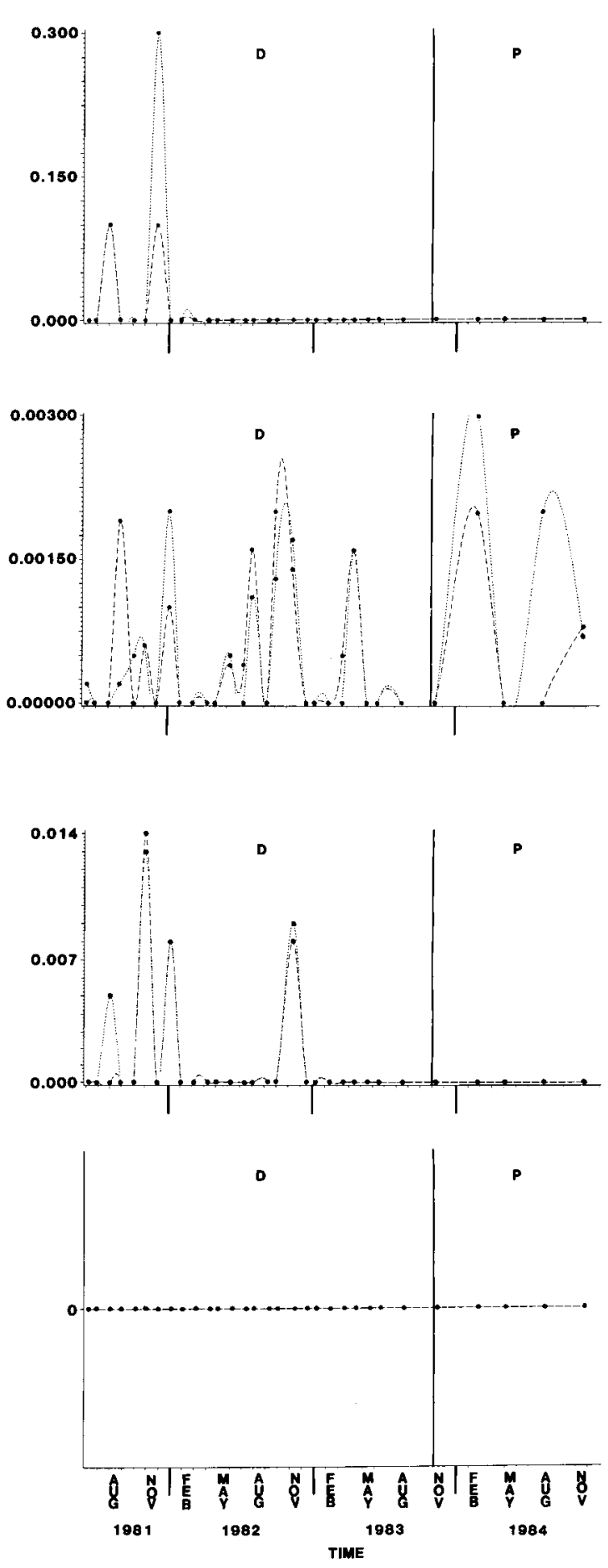
SURFACE WATERS
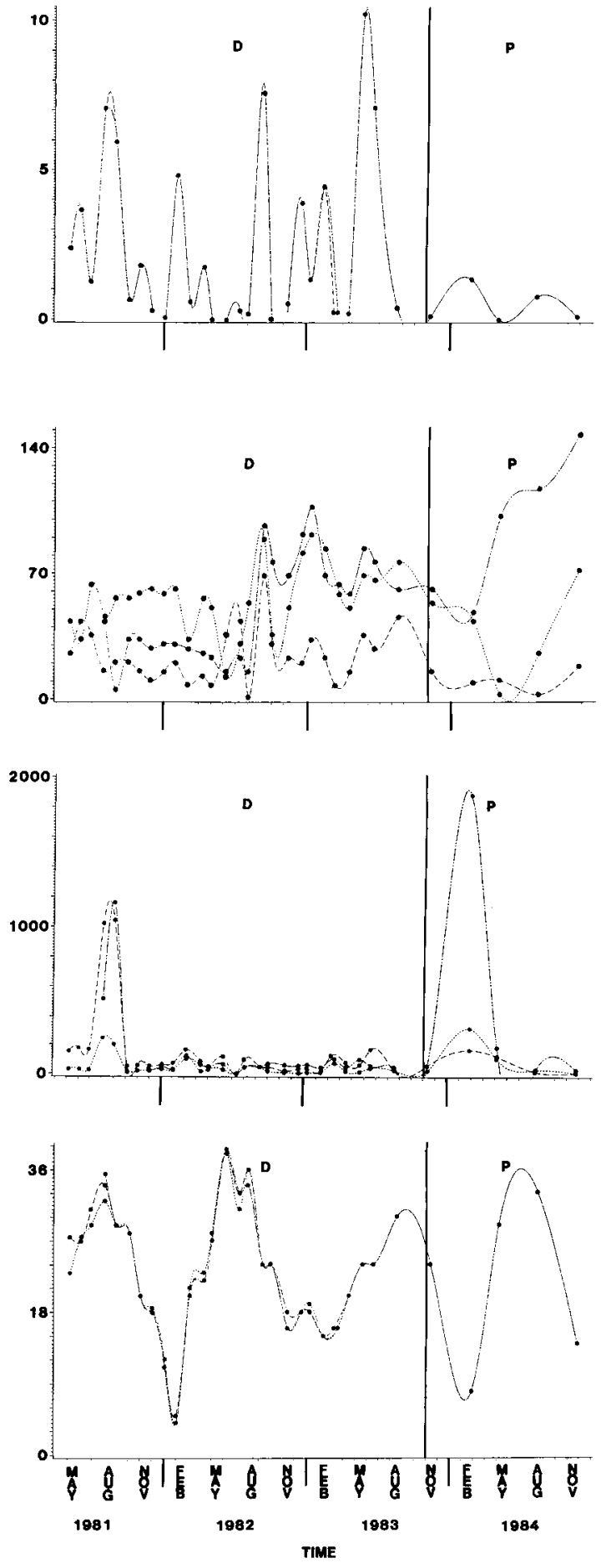

GROUND WATERS
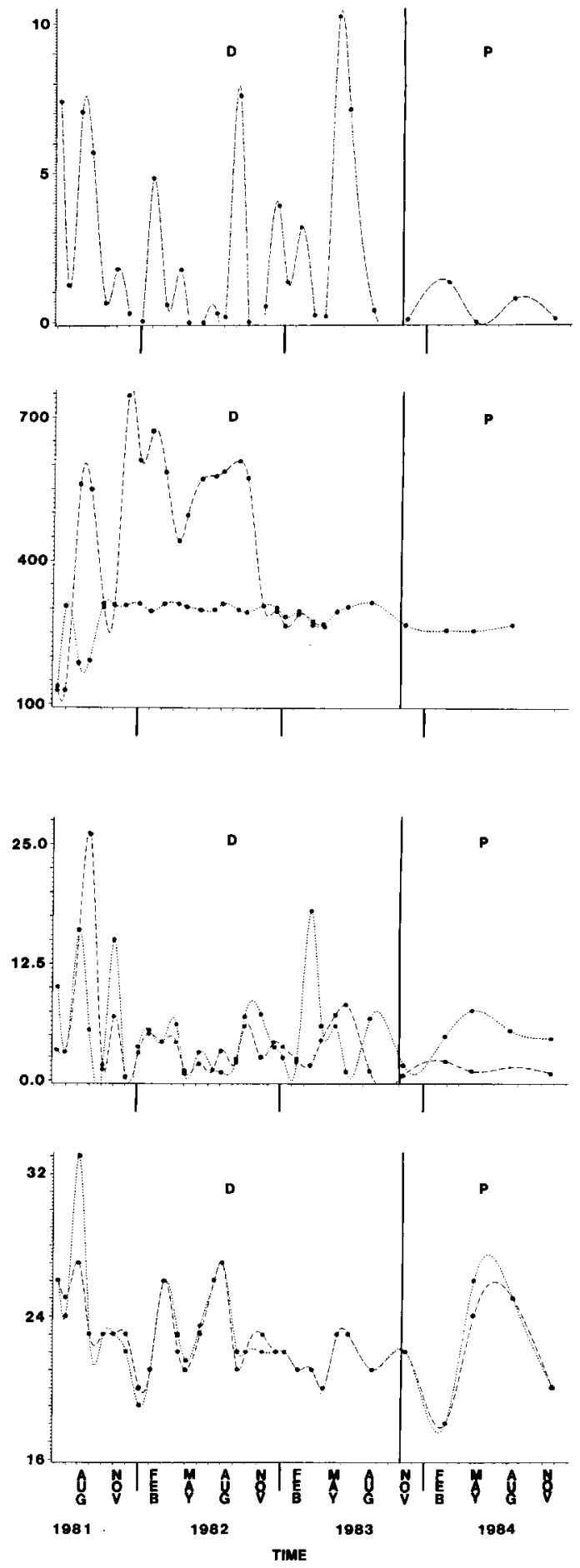
SUBSIDENCE MONITORING

by D. B. Trahan

\section{Introduction}

Subsidence monitoring networks around geopressured-geothermal prospects in southwestern Louisiana have been in place for five years. Repeated leveling surveys within these networks allow for a comparison of elevation changes for benchmarks between leveling epochs.

A paper discussing the results of subsidence monitoring at Parcperdue and Rockefeller Refuge was presented at the Sixth U.S. Gulf Coast GeopressuredGeothermal Energy Conference in February 1985 (Trahan, 1985). This paper has been included in this report as an appendix at the end of this section.

In summary, general subsidence rates measured at all test sites are small, ranging from $-0.12 \mathrm{in./ \textrm {yr }}(4 \mathrm{~mm} / \mathrm{yr})$ at Parcperdue to $-0.55 \mathrm{in.} / \mathrm{yr}(14 \mathrm{~mm} / \mathrm{yr})$ at Rockefeller Refuge. The greater subsidence rates at Rockefeller Refuge are considered to be related to the natural compaction of surficial marshland clays. The surface geologic unit at Parcperdue consists of sand and gravel and is hence less susceptible to compaction.

\section{Discussion}

Local anomalies at each test site may exceed general subsidence rates twofold. At Parcperdue, anomalies corresponded to the area around the geopressured-geothermal well pad during drilling operations and to an area of extensive ground-water withdrawal. These observations imply that the weight of drilling equipment was sufficient to cause loading of surficial soils. Rebound after the removal of drilling equipment indicated that the loading was 
temporary. The effects of ground-water production are inconclusive, although the problem has been well documented in Houston, Texas, and Baton Rouge, Louisiana (Lofgren, 1977; Wintz, Kazmann, and Smith, 1970). Geological constraints in these areas are similar to those at Parcperdue.

Subsidence monitoring at the Rockefeller Refuge geopressured-geothermal prospect also reflects the potential effect of well drilling. Subsidence around the well pad during drilling exceeded the general subsidence rate twofold and was much greater than the subsidence observed at Parcperdue. The greater subsidence at Rockefeller Refuge is interpreted to reflect the greater compressibility of marshland soils compared to the fluvial soils at Parcperdue. In addition, consistent displacement of the ground surface between all leveling epochs coincides with the areal extent of the Grand Chenier oil and gas field located northeast of the geopressured-geothermal prospect. This field has been producing 0 il, gas, and formation waters for over 30 years. Therefore, it is likely that some subsidence in the area is related to historical oil and gas production.

Consistently located displacements of the land surface have been observed at the Sweet Lake geopressured-geothermal prospect. However, the direction of surface movement from December 1980 to February 1982 is essentially the opposite of the direction of movement recorded during the period from February 1982 to August 1984 (Fig: 1). The reason for this phenomenon is unclear. It may be explained by fluctuating salt dome tectonics. The prospect is adjacent to the Sweet Lake salt dome, part of a trend of salt domes that includes the Hackberry dome to the west. Earlier subsidence studies found a correlation between land surface displacements and the positions of these salt domes (Trahan, 1982). If salt dome movement is occurring, then recent surveys (Fig. 1) imply that associated movements are cyclic and possibly oscillatory. Unlike the 

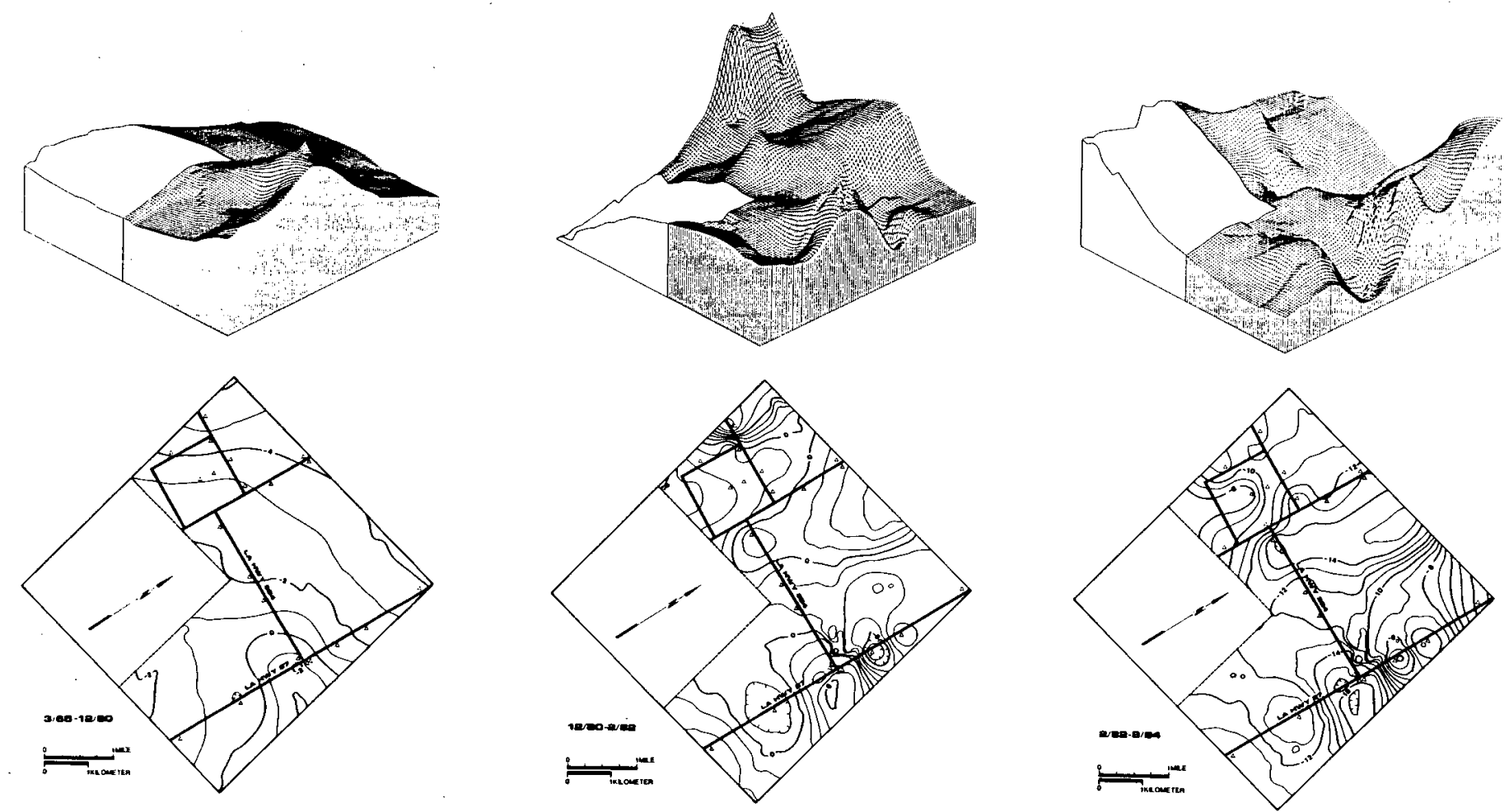

Figure 1. Elevation changes (in millimeters) for benchmarks around the Sweet Lake geopressured-geothemal prospect. Surface II Graphics (Sampson, 1978). 
other geopressured-geothermal subsidence monitoring networks, there are no anomalous movements at sweet Lake that can be ascribed to drilling activities.

\section{Summary}

The coastal plain in southwestern Louisiana is generally unstable. Deltaic progradation has built up a massive wedge of sediments on the rim of the Gulf of Mexico basin. These sediments are highly compressible and promote isostatic adjustments within the crust. Other phenomena such as salt dome tectonics and undercompaction in geopressured-geothermal corridors cause local and regional variations in land surface movements. In addition, for more than 30 years fluid withdrawal for oil and gas development has been displacing loadsupporting fluids throughout the coastal zone. Although the effects of groundwater withdrawal are not as drastic, these effects will cause more concern as ground-water development expands.

The effects of these phenomena should be evident in subsidence studies around geopressured-geothermal prospects in southwestern Louisiana. Groundwater production may be implicated in subsidence studies at Parcperdue, and one area of subsidence at Rockefeller Refuge coincides with historic oil and gas production. In addition, the effects of drilling activities are possibly evident at both these test sites.

The lack of similar coincidences at Sweet Lake may be due to the preponderance of movements associated with salt dome tectonics. The varied nature of land surface displacements may suggest this mechanism. If drilling or production operations did cause subsidence at Sweet Lake, the subsidence was probably small compared to natural background movements.

Subsidence monitoring studies should continue at all test sites in order to quantify natural and historical effects. Repeated surveys and modeling studies which account for the estimated impacts of various mechanisms may 
supply the statistical base necessary to more fully understand subsidence and subsidence-causing mechanisms in the Louisiana Gulf Coast.

\section{$\underline{\text { References }}$}

Lofgren, B. E., 1977, Background studies for appraising subsidence in the Texas Gulf Coast region: U.S. Geol. Survey Open-File Rept. 77-412, 28 p. Sampson, R. J., 1975 (Revised, 1978), Surface II Graphics System, Lawrence, Kansas, $240 \mathrm{p}$.

Trahan, D. B., 1982, Monitoring local subsidence in areas of potential geopressured fluid withdrawal, southwestern Louisiana: Trans., Gulf Coast Assoc. Geol. Socs., vol. 32, p. 231-36.

Trahan, D. B., 1985, Geopressured-geothermal development and coastal subsidence in Louisiana, in M. Dorfman and R. Morton, eds., Proc., sixth U.S. Gulf Coast geopressured-geothermal energy conference 4-5 Feb. 1985, Univ. Texas at Austin: Pergamon Press.

Wintz, W. A., R. G. Kazmann, and C. G. Smith, Jr., 1970, Subsidence and groundwater offtake in the Baton Rouge area: La. Water Resources Research Institute, Baton Rouge, Bull. no. 6, $29 \mathrm{p}$. 


\section{APPENDIX}

\section{GEOPRESSURED - GEOTHERMAL DEVELOPMENT AND COASTAL SUBSIDENCE IN \\ LOUISIANA}




\title{
GEOPRESSURED-GEOTHERMAL DEVELOPMENT AND COASTAL SUBSIDENCE \\ IN LOUISIANA \\ by Drukel1 B. Trahan
}

\begin{abstract}
Several investigators have shown that the main factors linking subsurface fluid withdrawal to subsidence are pore pressure reductions, depth and thickness of the producing interval, and formation rock properties, such as permeability and compressibility. The main cause of reservoir compaction is a reduction in reservoir pore pressure. High original pressures in geopressured reservoirs make these reservoirs prime candidates for compactional subsidence, provided that original pressures are not maintained by water ingress at the boundaries of the producing reservoir.

Elevation changes at the Parcperdue geopressured-geothermal test site in southwestern Louisiana range from 0.8 to $0.16 \mathrm{in} / \mathrm{yr}(+2$ to $-4 \mathrm{~mm} / \mathrm{yr})$ and reflect natural base-line movements associated with salt dome growth and the compaction of thick, recent sediments. Natural variation is the primary cause of greater movement at the nearby Rockefeller Refuge geopressured-geothemal test site where base-line movement rates range from -0.43 to -0.55 in/yr $(-12$ to $-14 \mathrm{~mm} / \mathrm{yr})$. Holocene sediments in the coastal marshlands at Rockefeller Refuge are more susceptible to compactional subsidence than upland Pleistocene formations at Parcperdue.

Anomalous subsidence at both test sites coincided with site preparation and well drilling and may have been related to loading of surficial soils by the weight of drilling equipment. Elevation changes monitored after drilling and during formation testing were consistent with base-line subsidence rates,
\end{abstract}


indicating that loading was temporary. Anomalous base-line subsidence rates coinciding with areas of historical fluid withdrawal indicate that these effects may outweigh the effects of present geopressured-geothermal development.

Base-line subsidence rates are also influenced by several other processes, including tectonics and natural compaction, which must also be considered. Regional effects are easily observed in statistical evaluations of geodetic data, but local variations are more difficult to separate from error. Repeated elevation surveys and models of compaction and subsidence may provide a statistical base for quantifying these effects.

\section{Introduction}

Compaction of reservoir rocks is a common problem associated with fluid withdrawal from subsurface formations. Compaction may alter the hydrodynamics and thus the producibility of the reservoir. The strata above the compacting reservoir may sag, causing casing failures and land surface subsidence. Methods have been defined which attempt to measure and predict compaction and surface subsidence above reservoirs which have produced large amounts of water or hydrocarbons (Fatt, 1958; Allen, 1968; Teeuw, 1971; Geertsma, 1973; Holzer, 1979). In all efforts, the focus of research has been to model reservoir production with parameters that define micro- and macroscopic reservoir properties. It has been shown that the main cause of reservoir compaction is a reduction in pore pressure which may vary, depending on fluid properties and rock properties such as permeability, lithology, porosity and cementation (Fatt, 1958; Geertsma, 1973). Land surface subsidence depends on other considerations, such as well spacing, production rates, and depth and thickness of the producing formation. Subsidence is most likely to occur in strata above a relatively shallow reservoir where boundary conditions, such as lateral 
confinement and lower permeabilities, prevent the maintenance of pore pressure within the reservoir.

One well-documented example of oil-field subsidence is in the harbor area of Long Beach, California, where $5 \mathrm{ft}(1.5 \mathrm{~m})$ of subsidence over a 10-year period was associated with pressure declines and compaction of reservoir sands in the Wilmington oil field (Gilluly and Grant, 1949). The subsidence was temporally and spatially correlated with reservoir pressure reductions, which were believed to have resulted from the lack of fluid influx through the reservoir boundaries. The authors showed that well failures due to thinning of reservoir sands were evident in the center of the field and that other possible causes of subsidence, such as tectonics and loading, could be ruled out or were insignificant.

Dther examples of subsidence due to fluid withdrawal are well known, including the Houston-Galveston region in Texas, where over $6 \mathrm{ft}(1.8 \mathrm{~m})$ of subsidence was attributed to head declines of 200-325 ft $(61-99 \mathrm{~m})$ in shallow aquifers east of Houston (Lofgren, 1977). The subsidence at Long Beach and Houston occurred above relatively shallow reservoirs less than $5000 \mathrm{ft}$ (1524 m) deep. The notable exception is an area of subsidence overlying the Chocolate Bayou geopressured $0 i 1$ and gas field southwest of Galveston (Lofgren, 1977). This field, with reservoirs $8000-13,000 \mathrm{ft}(2438-3962 \mathrm{~m})$ deep, is characteristic of other oil and gas fields in the geopressured-geothemal corridor along the northwestern Gulf of Mexico. Sand and sandstone reservoirs in the geopressured zone are trapped within faulted blocks of massive shales. Reservoir pore pressures exceed normal hydrostatic pressures due to undercompaction and geostatic loading in addition to normal hydrostatic loading; the rate of natural dewatering is slow due to very low permeabilities in the adjacent shales. Production from a geopressured reservoir may cause depressurization and compaction of the reservoir and an increase in the hydraulic gradient at the reservoir 
boundaries. Dewatering and compaction of reservoir sediments may result in a surface subsidence rate greater than base-line subsidence rates.

Subsidence monitoring networks have been established at three geopressured-geothermal prospects in southwestern Louisiana: Parcperdue, Rockefeller Refuge, and Sweet Lake (Fig. 1). In these networks, steel rods driven 50-100 $\mathrm{ft}(15-30 \mathrm{~m})$ deep were spaced approximately $0.6 \mathrm{mi}(1 \mathrm{~km})$ apart in order to minimize the effects of local processes such as the thermal expansion and contraction of surface soils. Elevation changes of benchmarks in these networks should therefore reflect movements below the soil zone and at an areal scale measured in kilometers. Records of elevation change above geopressuredgeothermal prospects in southwestern Louisiana may only partially reflect the effects of geopressured-geothermal development. The subsidence record in coastal Louisiana may include the effects of regional tectonics, natural compaction, historical oil and gas activities, shallow groundwater withdrawal, and the loading and surface drainage of marshy soils. These effects, which should be measured independently, are considered for the Parcperdue and Rockefeller Refuge prospects; analysis of elevation changes at Sweet Lake are forthcoming.

\section{The Coastal Louisiana Subsidence Record}

One component of subsidence in coastal Louisiana is the result of deep stresses associated with the tectonics of the Gulf Coast geosyncline and with the weight and compaction of the thick sediments which comprise the geosyncline. This regional subsidence ranges from 0 in/yr in northern Louisiana to $0.24 \mathrm{in} / \mathrm{yr}(5 \mathrm{~mm} / \mathrm{yr})$ in southern Louisiana and is greatest in the Mississippi Delta region (Holdahl and Morrison, 1974). The work by Holdahl and Morrison was based on a regional adjustment of leveling data and tidal records for the southeastern United States. 


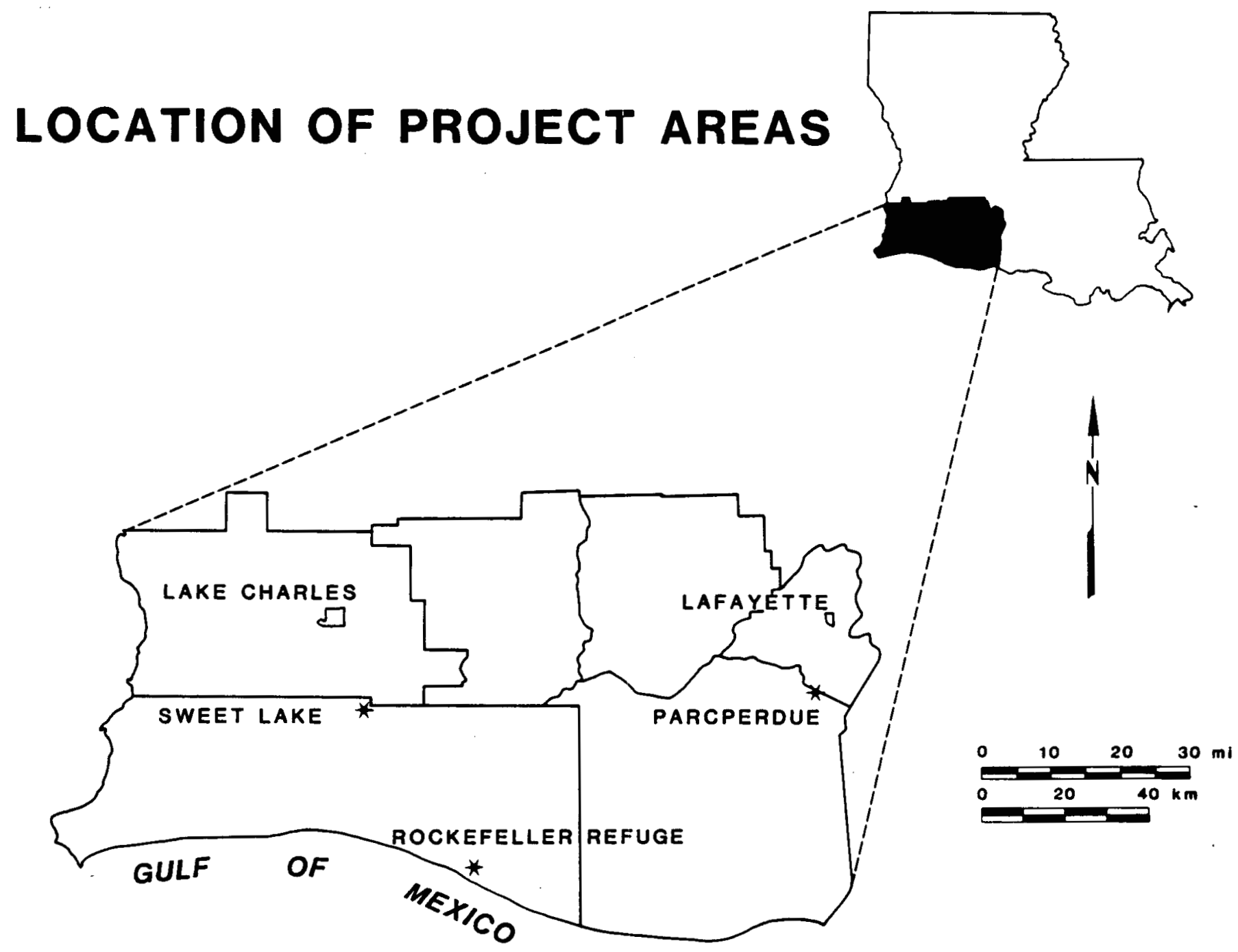

Figure 1. Location of geopressured-geothermal prospects, southwestern Louisiana. 
The use of a closely spaced benchmark network extending from northeastern to southwestern Louisiana resulted in a range of subsidence rates greater than the regional trend established by Holdahl and Morrison (Trahan, 1983). Relative movements ranged from $-0.72 \mathrm{in} / \mathrm{yr}(-17 \mathrm{~mm} / \mathrm{yr})$ within major river valleys to $+0.12 \mathrm{in} / \mathrm{yr}(+4 \mathrm{~mm} / \mathrm{yr})$ along the "Five Islands" salt dome trend. Anomalous subsidence in river valleys was probably attributable to the compaction of Holocene sediments filling the river valleys, which are less stable than Pleistocene uplands. The Five Islands are salt diapirs intruding Pleistocene sediments along a line from $15 \mathrm{mi}(24 \mathrm{~km})$ southeast of Lafayette and extending 50 mi $(80 \mathrm{~km})$ southeast through Holocene marshlands and bays. Uplift in this area may be due to salt tectonics. Other local effects, such as growth faulting, have been observed in geodetic studies of the Baton Rouge industrial sector (Wintz, Kazmann, and Smith, 1970) along with subsidence caused by groundwater withdrawal. The effects of growth faulting and smaller scale effects, such as fluid withdrawal, surface loading, and surface drainage, are not readily apparent in regional studies where benchmark spacings may span distances one or two orders of magnitude greater than the areal extent of surface movements associated with these small-scale effects. Elevation changes in denser benchmark networks around the Parcperdue and Rockefeller Refuge geopressured-geothemal prospects should reflect the regional as well as localized movements.

\section{Rockefeller Refuge}

Elevation changes in the Rockefeller Refuge benchmark network were referenced to base-line subsidence rates at benchmarks along a historical survey line, which parallels the Chenier Plain of southwestern Louisiana between Creole and Rockefeller Refuge, Louisiana. In general, subsidence along this line increases from east to west toward the depocenter associated with Sabine River deltation; local anomalies coincide with the positions of smaller river 
valleys. Subsidence within the Rockefeller Refuge network ranged from $0.43-$ $0.55 \mathrm{in} / \mathrm{yr}(10-14 \mathrm{~mm} / \mathrm{yr})$ between October 1981 and July 1984 (Fig. 2). Most of this subsidence probably reflects the high compressibility of young Holocene sediments. Soil borings taken during the course of this study revealed plastic clay $100 \mathrm{ft}(30 \mathrm{~m})$ thick around the well site. Subsidence during the first year of development, June 1982 to July 1984, was greatest near the well pad. Four benchmarks around the well pad each registered relative movements of -0.72 to $-0.96 \mathrm{in} / \mathrm{yr}(-18$ to $-23 \mathrm{~mm} / \mathrm{yr})$ as compared to base-1ine rates at most other benchmarks in the network (Fig. 3). No activities other than well drilling were recorded at the test site during this time. This anomalous subsidence may have resulted from vibrations and loading of the site during preparation and well drilling. There is evidence that some rebound occurred after the drilling equipment was removed. Base-line subsidence rates were recorded at the test site from June 1982 to July 1984, and the total change from October 1981 to July 1984 indicated base-line movement only (Fig. 2).

No effects of geopressured-geothermal brine production are evident at this time. However, maximum base-line subsidence along state Highway 82 (Fig. 2) coincides with the areal extent of hydrocarbon production from the Grand Chenier field located northeast of the test site (Fig. 4). Twenty-eight wells in this field have produced mostly gas from a perforated interval up to $31 \mathrm{ft}$ (9 m) thick. The average depth of the producing interval is $9102 \mathrm{ft}(2774 \mathrm{~m})$. This field is generally shallower and more productive than other fields in the area. In contrast, the Rockefeller Refuge geopressured-geothermal reservoir lies at a depth of approximately $16,000 \mathrm{ft}(4877 \mathrm{~m})$ and is $100 \mathrm{ft}(30 \mathrm{~m})$ thick. Although the maximum base-line subsidence measured in this area (Fig. 2) is smal1, this rate of subsidence, if representative of nomal yearly movement, is similar in magnitude to the general rate of subsidence above the Chocolate Bayou geopressured oil and gas field in Texas. Subsidence in this area 

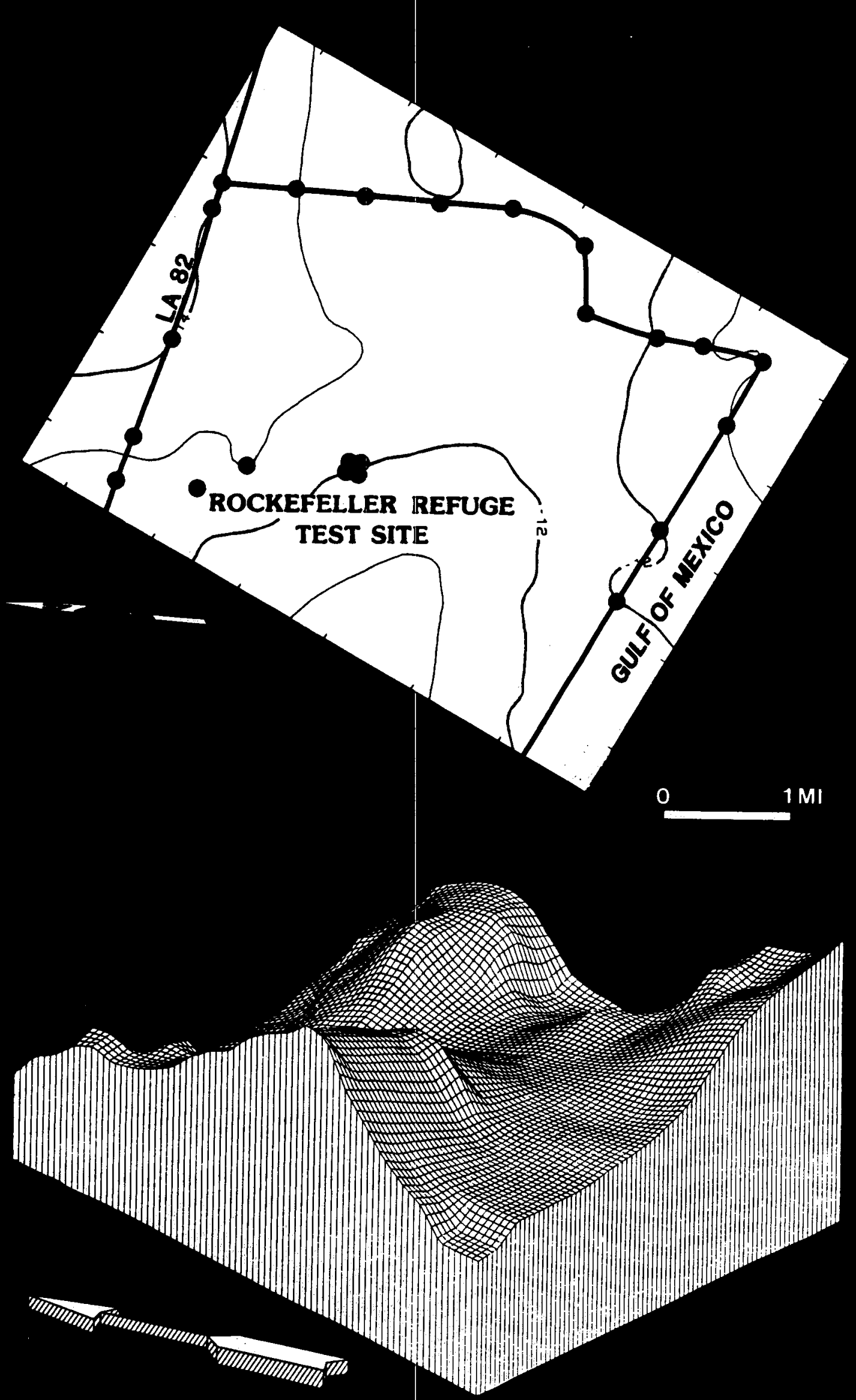

Figure 2. Subsidence rates (mm/yr) for benchmarks around the Rockefeller Refuge geopressured-geothermal prospect, October 1981 to July 1984. 


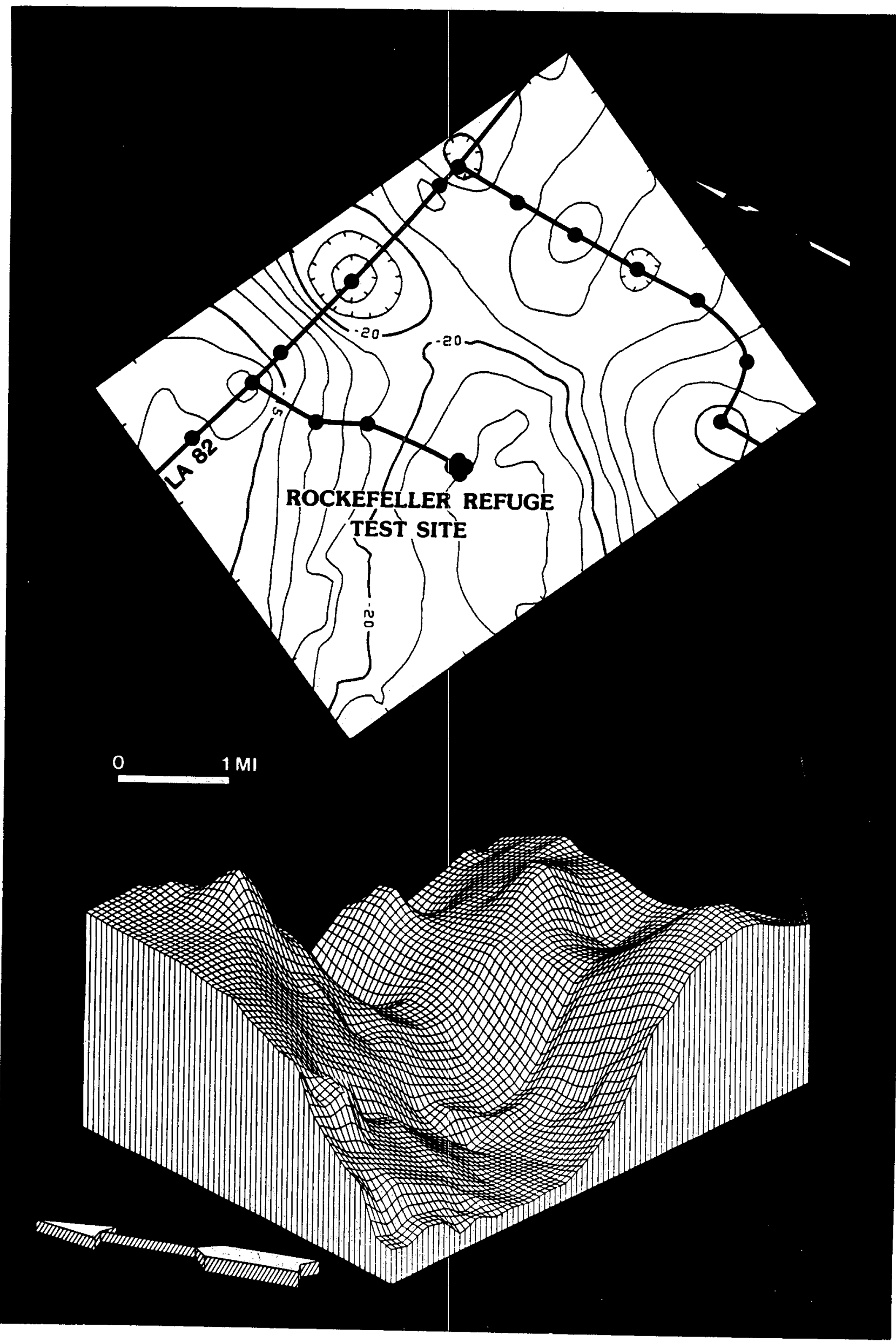

Figure 3. Subsidence rates $(\mathrm{mm} / \mathrm{yr})$ for benchmarks around the Rockefeller Refuge geopressured-geothermal prospect, October 1981 to June 1982. 


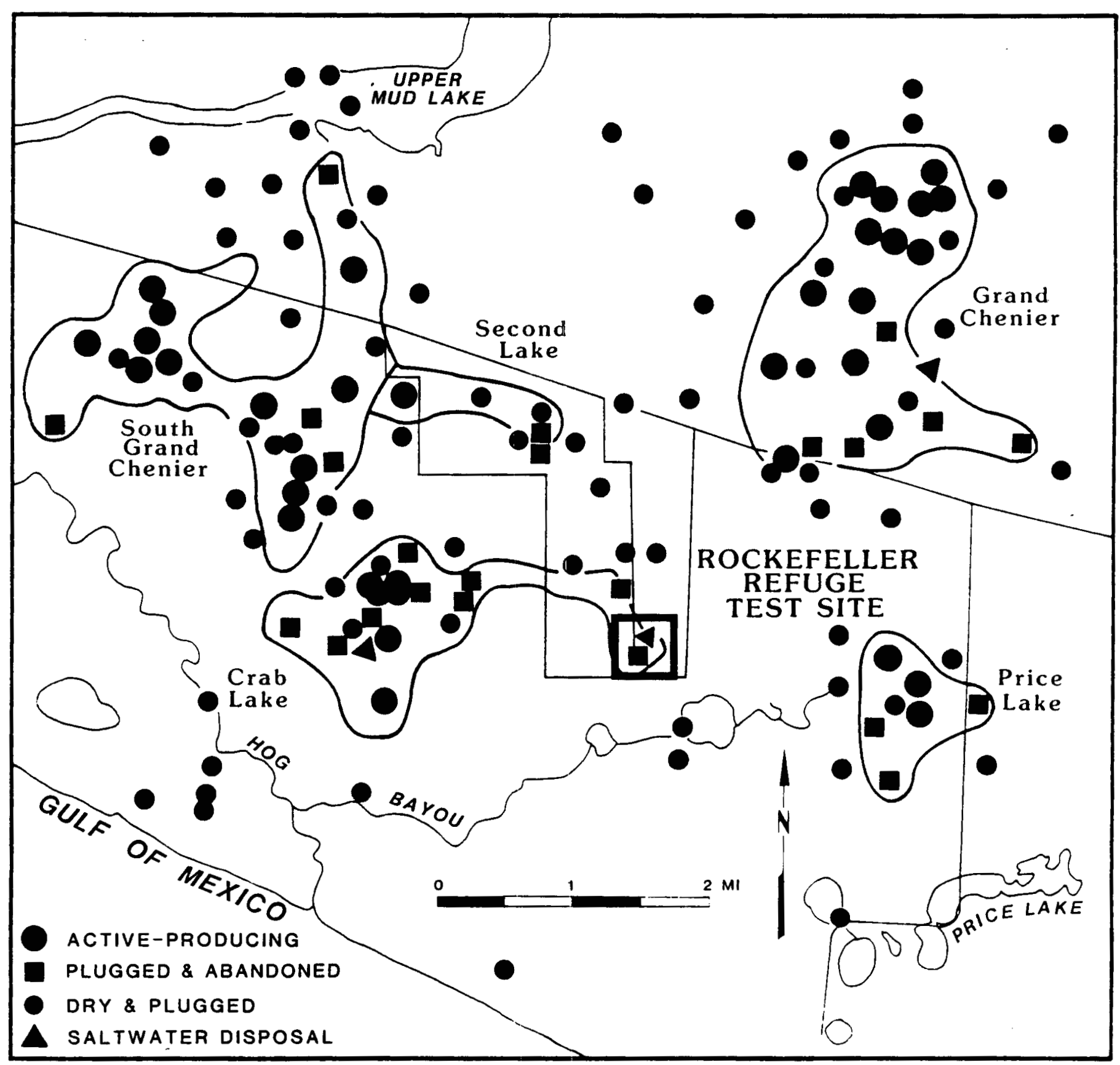

Figure 4. Historical oil and gas development at Rockefeller Refuge. 
measured $1.75 \mathrm{ft}(0.5 \mathrm{~m})$ over a 30-year period (Lofgren, 1977), which is equivalent to a yearly rate of $0.72 \mathrm{in} / \mathrm{yr}(18 \mathrm{~mm} / \mathrm{yr})$.

Pressures in the Rockefeller Refuge geopressured-geothermal reservoir have declined about 1000 psi during 1.25 years of production (Berning, 1984, personal communication). Although pressure data are lacking for historical oil and gas production, it is likely that pressures have declined considerably during the $30+$ years these fields have been producing. These fields are also shallower than the geopressured-geothermal reservoir and are located on the updip side of a major fault. Historical hydrocarbon production is therefore a likely contributing factor to subsidence in this area and probably exceeds subsidence due to geopressured-geothermal development to date.

\section{Parcperdue}

Elevation changes of benchmarks in the Parcperdue subsidence monitoring network have been referenced to the movement of a benchmark in Lafayette along a survey line which traverses southern Louisiana from Orange, Texas, to Baldwin, Louisiana (Trahan, 1983). Anomalous subsidence west of Lafayette between the Mermentau and Vermilion rivers is centered on a Pleistocene depocenter discussed by Varvaro (1957). Upl ift is indicated from Lafayette to the southeast where the survey parallels the axis of the Five Islands salt dome trend. Land surface movements at the Parcperdue test site reflect this general trend (Trahan, 1984). The SYMAP procedure (Dougenik and Sheehan, 1977) was used to contour the velocities of movement and to establish weighted trend surfaces for each of the periods 1980-81 and 1981-83. In both instances, the second-order trend surface was most significant. The trend slopes gradually from t0.08 $\mathrm{in} / \mathrm{yr}(+2 \mathrm{~mm} / \mathrm{yr})$ in the southeast to $-0.12 \mathrm{in} / \mathrm{yr}(4 \mathrm{~mm} / \mathrm{yr})$ in the northwest (Trahan, 1984). Subsidence due to natural compaction at Parcperdue is much less than that observed at Rockefeller Refuge. Pleistocene uplands at 


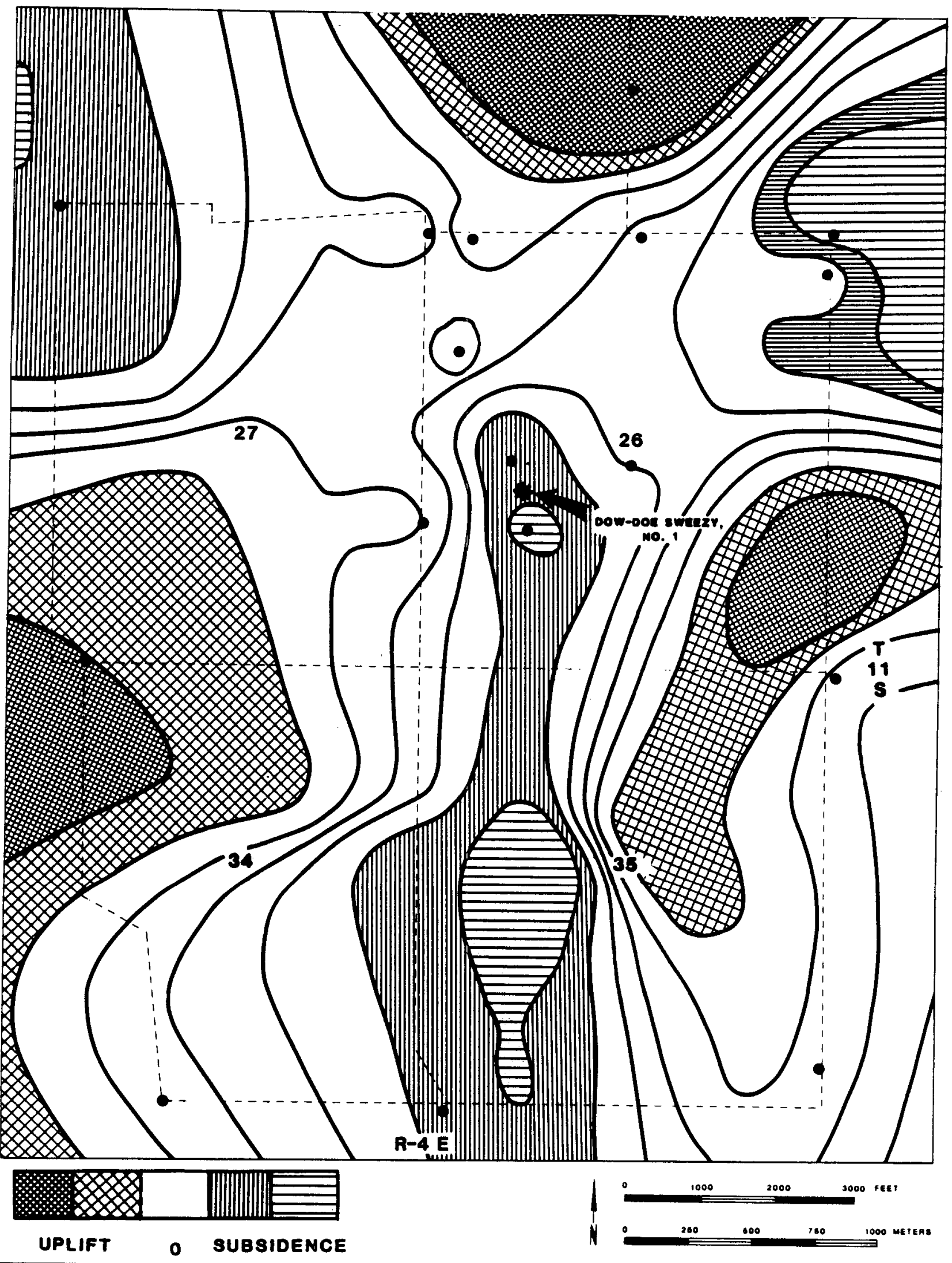

Figure 5. Second-order residual surface for elevation changes (mm/yr) for benchmarks around the Parcperdue geopressured-geothermal prospect, 1980-81. 


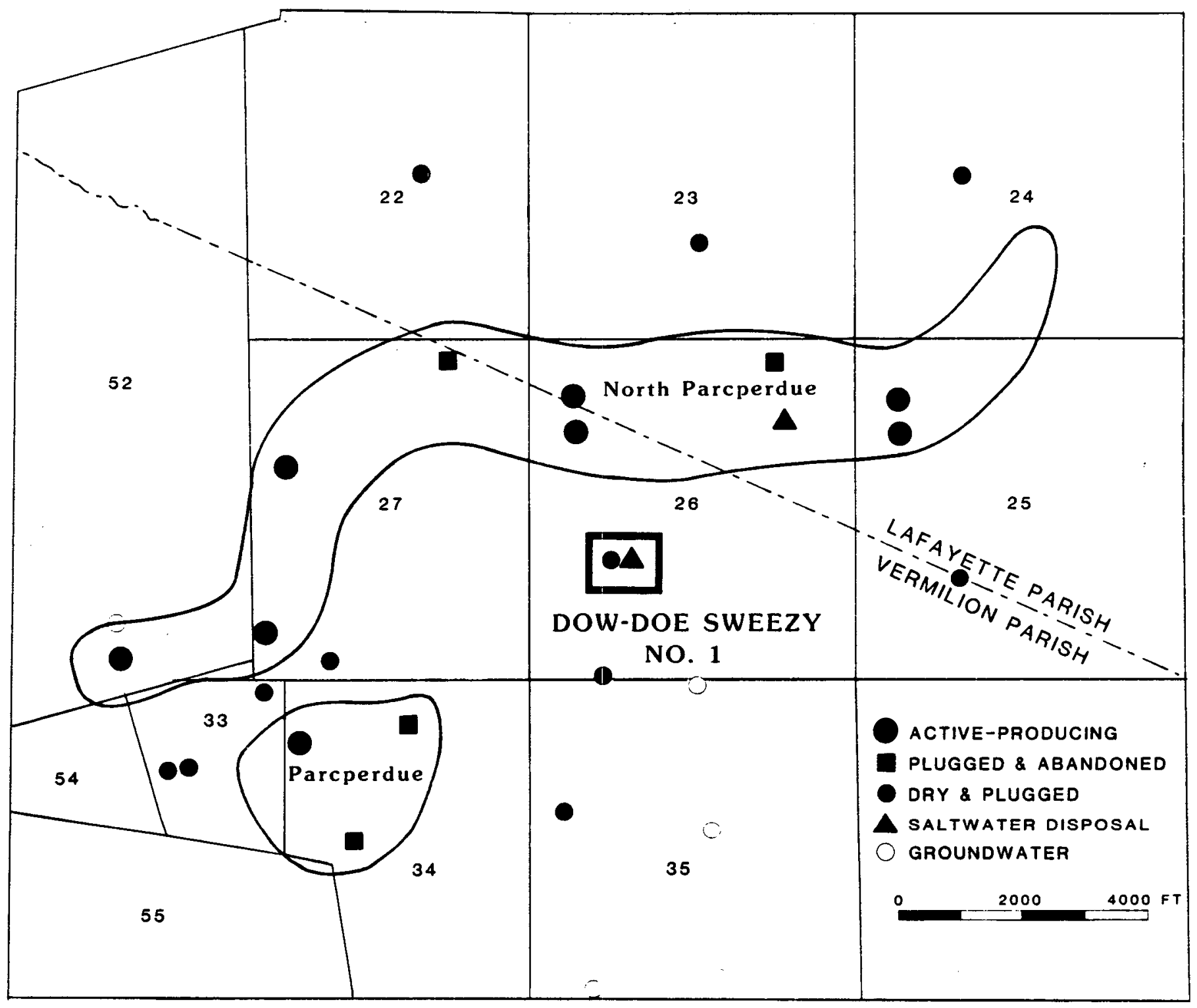

Figure 6. Historical oil, gas, and groundwater development at Parcperdue. 
Parcperdue consist mostly of sands and gravels deposited by an ancestral Mississippi River. Soils formed in these sediments are not as compressible as marshland clays.

Residuals not aligned with the general trend are considered to represent anomalies not associated with regional subsidence. Residual subsidence during 1980-81 is indicated around DOW-DOE Sweezy, no. 1, the well which produced from the Parcperdue geopressured-geothermal reservoir (Fig. 5). No activity other than site preparation and drilling was observed at the site during this time. This subsidence may be due to the temporary loading and compaction of the surface due to the weight of the drilling equipment. The same anomaly is not evident for the second period of monitoring when drilling operations had ceased. Uplift residuals at the site during 1981-83 indicate that rebound may have occurred after removal of the drilling equipment.

Anomalous subsidence rates range from $0-0.02 \mathrm{in} / \mathrm{yr}(0-0.5 \mathrm{~mm} / \mathrm{yr})$. These small rates are lower than error limits common to surveying and can not be readily associated with local activities such as oil and gas production (Fig. 6). However, the anomaly located south of the test site during 1980-81 was also apparent during 1981-83. In this area, groundwater is withdrawn from shallow subsurface formations for rice irrigation. From April 1978 to May 1983, two wells in this area produced approximately 48 million barrels of water. A relationship between groundwater withdrawal and subsidence is not conclusive. A significant head decline must occur in a producing groundwater reservoir for compaction to occur. As with deeper reservoirs, the amount of compaction and subsidence is also dependent on the permeability of the formation and the rate of recharge in relation to the production rate as well as other rock and fluid properties. 
Subsidence in the areas surrounding geopressured-geothermal prospects in southwestern Louisiana may be due to combined regional and local effects. The statewide regional trend reflects greater subsidence along the Gulf Coast due to the thickness, weight, and compressibility of sediments in the Gulf coast geosyncline. Anomalies from the regional trend correlate strongly with river valleys and salt domes. Subsidence rates around the Rockefeller Refuge geopressured-geothermal prospect were about three times greater than subsidence rates measured at the Parcperdue geopressured-geothemal prospect. The Rockefeller Refuge test site is situated within Holocene coastal marshlands. These soils are probably more susceptible to compaction than soils at Parcperdue, which formed in older Pleistocene uplands.

Elevation changes in benchmark networks around the geopressured-geothermal test sites should reflect regional variations in addition to local activities such as groundwater, oil, and gas withdrawal and surface loading. Maps of elevation change for the Rockefeller Refuge geopressured-geothermal prospect indicate loading at the well site during site preparation and drilling and the possible effects of historical hydrocarbon production. The effects of surface loading during drilling are also evident at the Parcperdue geopressuredgeothermal test site. In addition, one subsidence anomaly coincides with an area of groundwater production. Subsidence monitoring has corresponded to two years of geopressured-geothermal testing. No relationship between geopressured-geothermal production and subsidence is apparent from these data, possibly due to the amount of time required to transmit compactional stresses to the surface.

The short-term measurements made at the geopressured-geothermal test sites are subjective. Although local effects may be more readily apparent in these data than in regional adjustments, the chance for error may be greater. Over 5 
feet of subsidence was measured in Long Beach, California, and in Houston, Texas. These studies were based on long-term elevation changes measured over decades. It may not be necessary to monitor subsidence for a comparable length of time at the geopressured-geothermal test sites, but repeated yearly elevation surveys would provide a statistical base for separating error from actual movement. In addition, data on rock properties and hydrologic characteristics from groundwater aquifers and $0 i 1$ and gas fields may provide the input for models which could quantify subsidence related to these causes.

\section{Acknowledgments}

This work was sponsored by the U.S. Department of Energy, contract no. DE-AC08-81NV10174. Thanks are due to Louisiana Geological Survey personnel Tangular Williams, word processor operator, and Dorothy Blades, cartographer. The manuscript was reviewed by Whitney Autin, Rick McCulloh, and Don Stevenson of the Louisiana Geological Survey.

\section{References}

Allen, D. R. (1968). Physical changes of reservoir properties caused by subsidence and repressuring operations. ‥ Petr. Tech., 20, 1, 23-29.

Berning, J. (1984). Personal communication. Site manager, Technadril-Fenix Scisson, Houston, TX.

Dougenik, J. A., and D. E. Sheehan (1977). SYMAP user's manual. Laboratory for Computer Graphics and Spatial Analysis, Graduate School of Design, Harvard.

Fatt, I. (1958). Compressibilities of sandstones at low to moderate pressures. AAPG Bu11., 42, 1924-1957.

Geertsma, J. (1973). Land subsidence above compacting oil and gas reservoirs. J. Petr. Tech., June, 734-744. 
Gilluly, J., and U. S. Grant (1949). Subsidence in the Long Beach harbor area, California. GSA Bul1., 60, 3, 461-530.

Holdaht, S. R., and N. L. Morrison (1974). Regional investigations of vertical crustal movements in the U.S., using precise relevelings and mareograph data. In R. Green (Ed.), Recent crustal movements and associated seismic and volcanic activity. Tectonophysics, 23, 373-390.

Holzer, T. L. (1979). Elastic expansion of the lithosphere caused by groundwater depletion. ‥ Geophysical Research, 84, 89, 4689-4698.

Lofgren, B. E. (1977). Background studies for appraising subsidence in the Texas Gulf Coast region. U.S. Geol. Survey Open-File Rept. 77-412, 28 pp. Teeuw, D. (1971). Prediction of formation compaction from laboratory compressibility data: Soc. Petr. Eng. J., $11,3,263-271$.

Trahan, D. B. (1983). Regional and Tocal subsidence in Louisiana. In Proceedings from the conference on land subsidence and earth fissuring. Arizona Consulting Engineers Association, Phoenix, Arizona (in press).

Trahan, D. B. (1984). Results from geopressured-geothermal subsidence studies. In Proceedings from the conference on compressibility phenomena in subsidence. Engineering Foundation, New York (in press).

Varvaro, G. G. (1957). Geology of Evangeline and St. Landry parishes. Dept. Conservation, La. Geol. Survey, Baton Rouge, La., Geol. Bul1. No. 31, p. 23, pl. 2 .

Wintz, W. A., R. G. Kazmann, and C. G. Smith, Jr. (1970). Subsidence and groundwater offtake in the Baton Rouge area. La. Water Resources Research Institute, Baton Rouge, La., Bu11. No. 6, 29 pp. 
MICROSEISMIC MONITORING

by D. A. Stevenson

\section{Abstract}

Continuous microseismic monitoring networks have been established around three U.S. Department of Energy (DOE) geopressured-geothermal design wells in southwestern Louisiana since summer 1980 to assess the effects well development may have on subsidence and growth fault activation. The results obtained from this monitoring have shown several unusual characteristics associated with Gulf Coast seismic activity. The observed activity is classified into two dominant types, one with identifiable body phases and the other with only surface wave signatures. The latter type comprises over $99 \%$ of the reported $1000+$ microseismic event locations. The problem with the slow-moving surface-wave signature events is that rainfall and weather-associated frontal passages seem closely related to these periods of seismic activity at all three wells.

After relatively short periods and low levels of flow testing at the Parcperdue and Sweet Lake prospects, seismic monitoring has shown little credible correlation to inferred growth fault locations during periods of flow testing. Longer periods and higher volumes of flow testing at the Rockefeller Refuge prospect should provide a truer indication of induced seismicity attributable to geopressure-geothermal development.

\section{Introduction}

The Louisiana Geological Survey and Louisiana State University have conducted base-line seismic studies at the U.S. Department of Energy Parcperdue, Sweet Lake, and Rockefeller Refuge prospects to investigate microseismicity 
associated with geopressured-geothermal fluid production. These monitoring programs were designed, first, to establish the nature of the local seismic activity prior to production and, second, to determine if well activities induce changes in the rate of local fault movement. This section describes the results obtained from microseismic monitoring at Parcperdue, Sweet Lake, and Rockefeller Refuge (Fig. 1) through December 1984. Seismic data presented for the Sweet Lake, Rockefeller Refuge, and Parcperdue prospects are taken from quarterly reports submitted to the university by our subcontractors, WoodwardClyde Consultants and Teledyne Geotech.

\section{$\underline{\text { Louisiana Microseismic Monitoring Networks }}$}

The seismic networks that have been deployed around the Parcperdue, Sweet Lake, and Rockefeller Refuge prospects are shown in Figures 2-4 with location coordinates given in Table 1. Continuous microseismic monitoring at Parcperdue began in August 1980 and continued through November 1983. The Sweet Lake and Rockefeller Refuge networks have been on line since late summer 1981 and continue to operate at present.

Each network has consisted of from five to eight short-period vertical seismometers. To reduce the adverse effect of surface cultural noise on the data, seismometers were installed in boreholes up to $30 \mathrm{~m}(100 \mathrm{ft})$ deep. The seismic signals detected at each site within a network are sent to the central recording facility, where the individual station signals are demultiplexed from their respective carriers and continuously recorded. Records are scanned daily to detect possible natural seismic activity. All events that are thought to be local microearthquakes are processed to obtain hypocenter locations and relative magnitudes. The hypocenter is determined by using computer algorithms similar to HYP071 (Lee and Lahr, 1975). Magnitudes are calculated on the basis of event duration. Since a magnitude scale has not been developed for the Gulf 


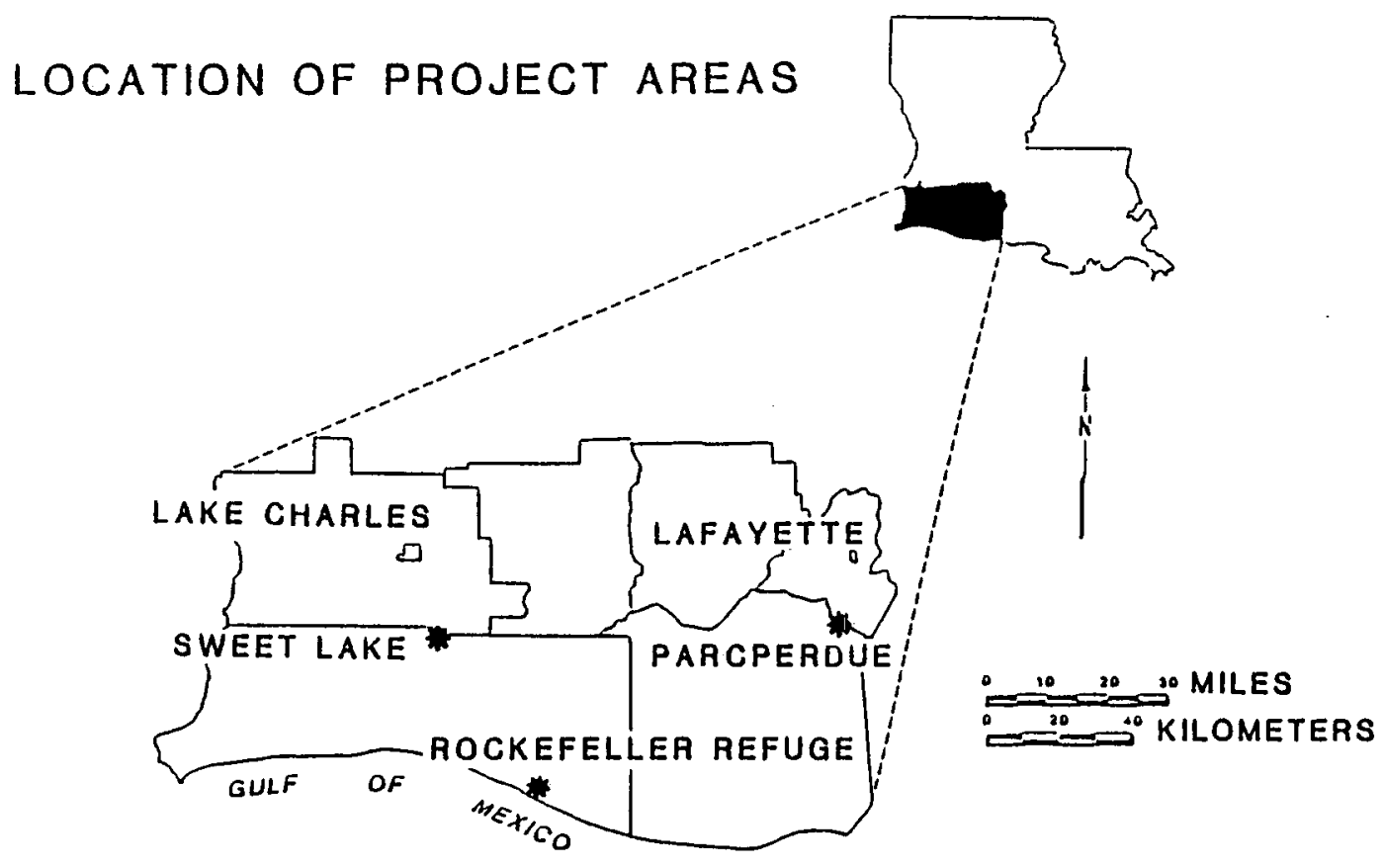

FIGURE 1. Locations of the DOE Sweet Lake, Parcperdue, and Rockefeller Refuge geopressured-geothermal prospects in Louisiana. 


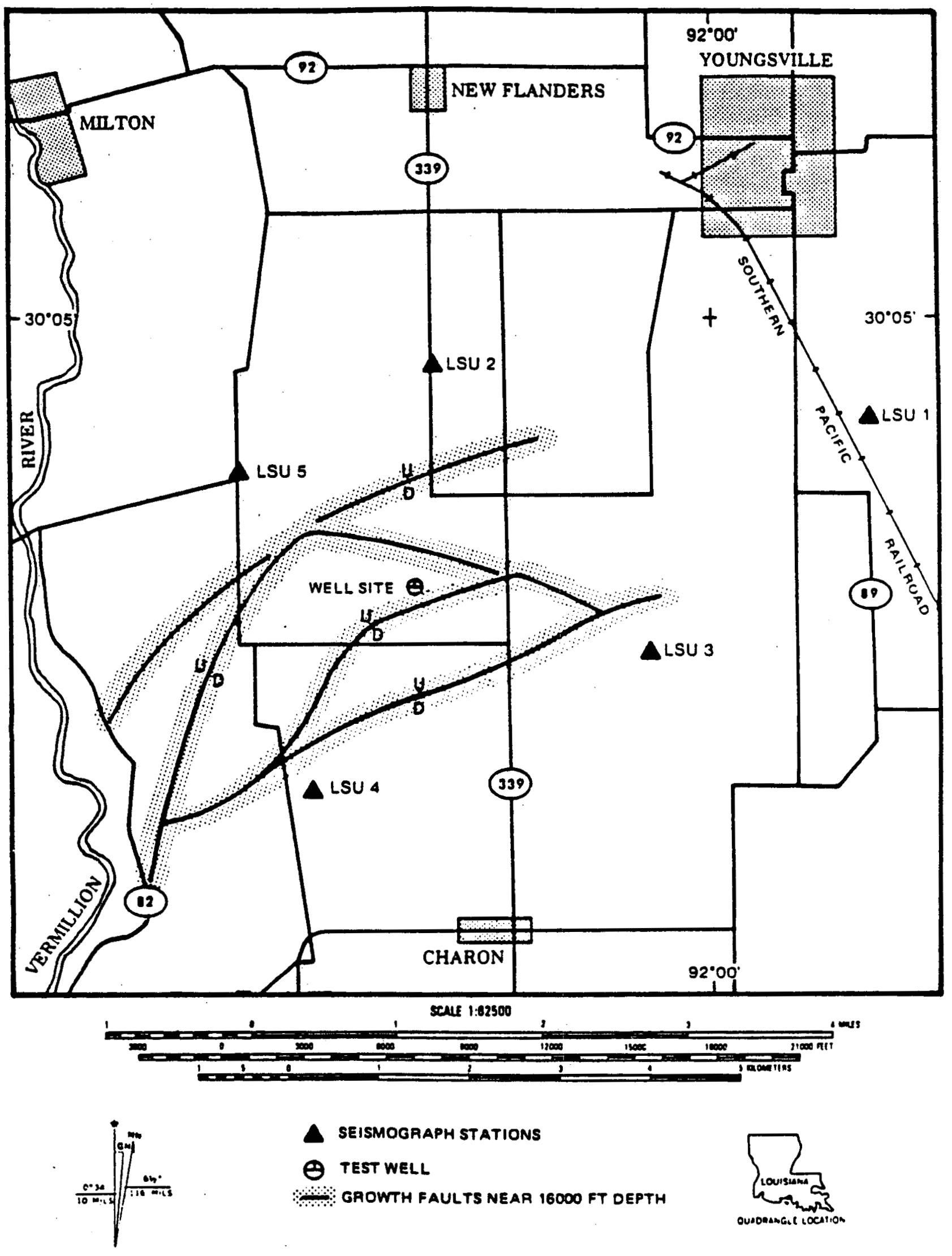

FIGURE 2. Parcperdue seismic array. 


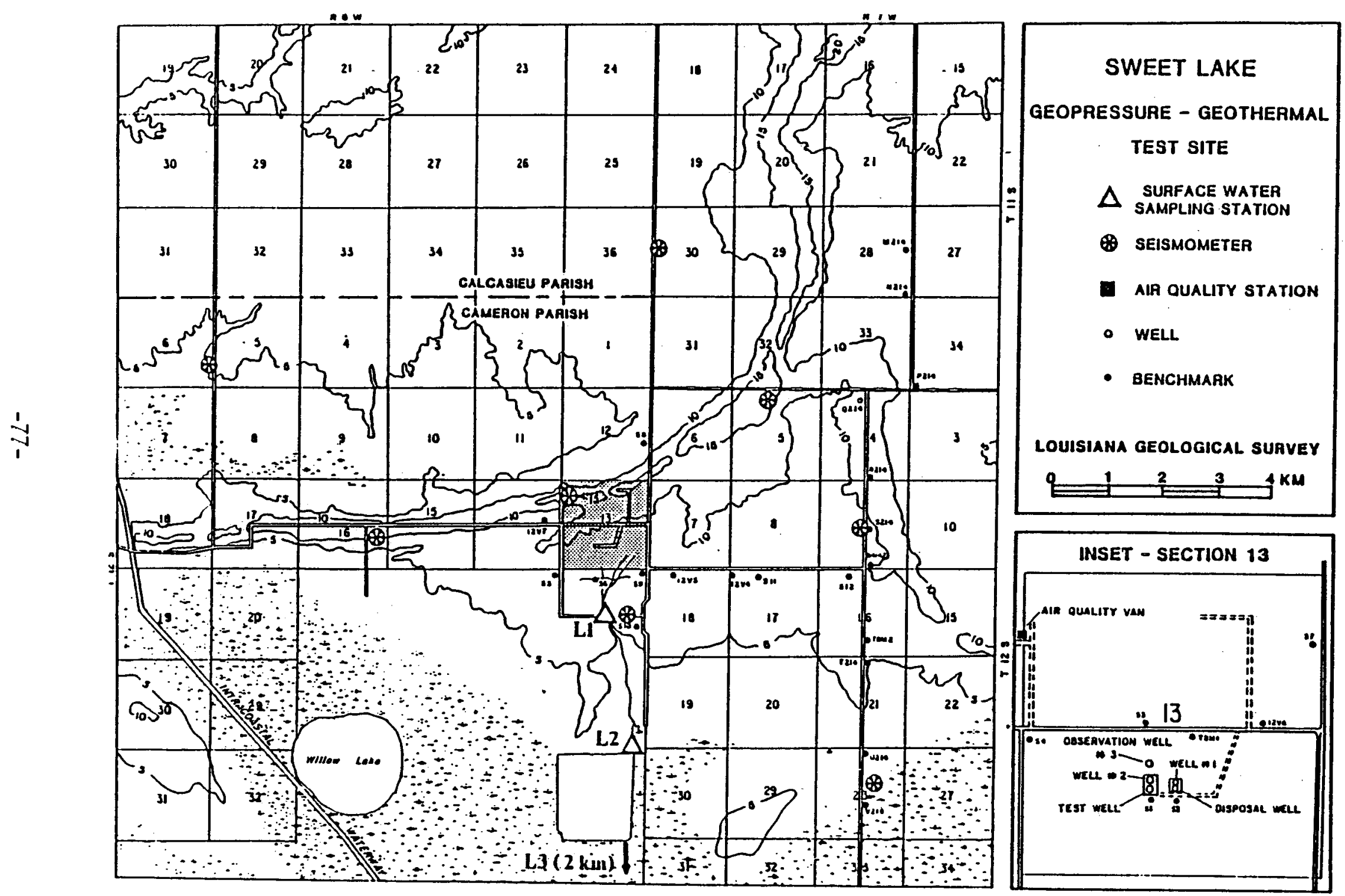

FIGURE 3. Sweet Lake seismic array. 


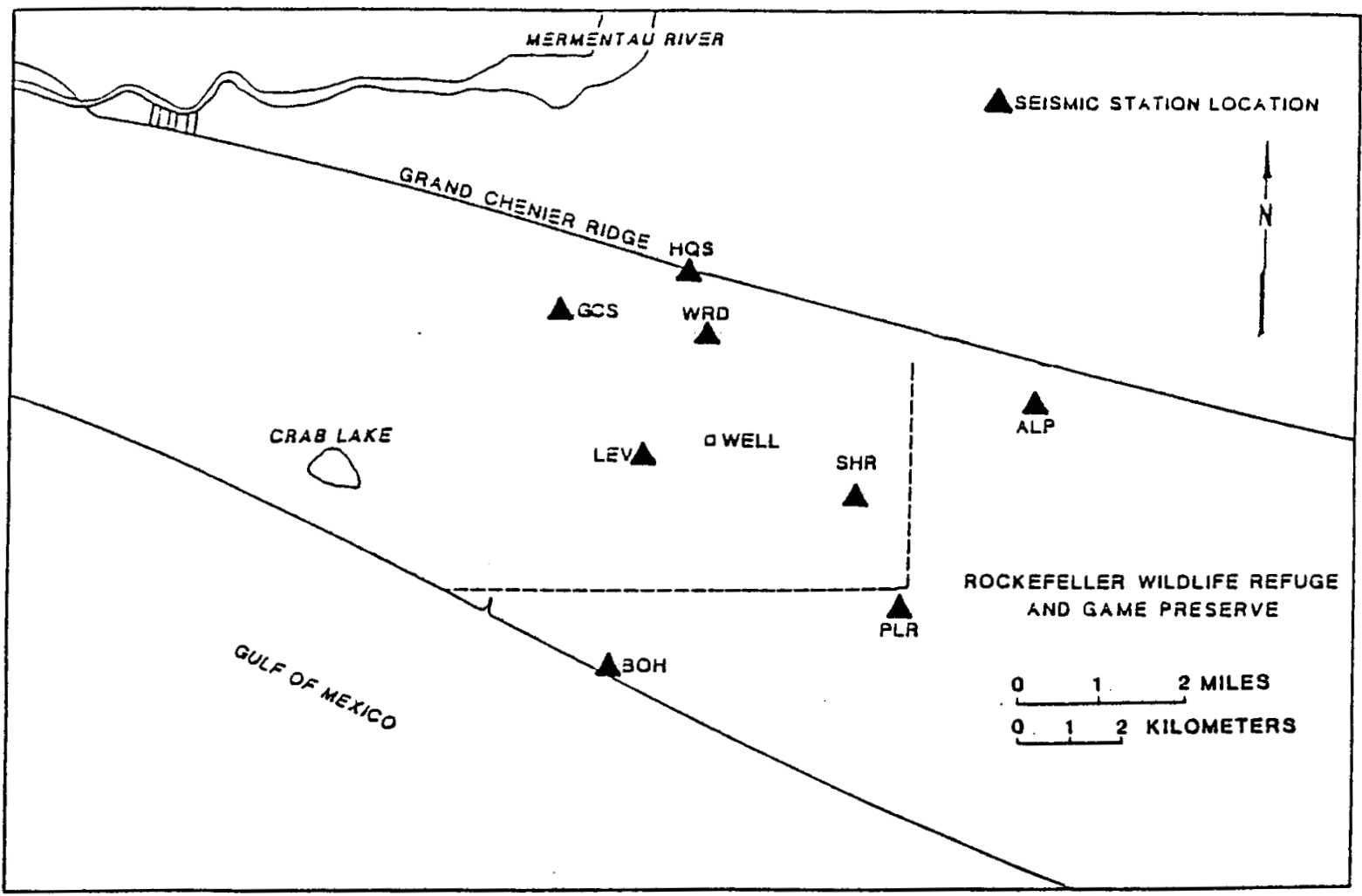

FIGURE 4. Rockefeller Refuge seismic array. 
TABLE 1. Coordinates for Parcperdue, Sweet Lake, and Rockefeller Refuge seismic monitoring networks.

PARCPERDUE

\section{LSU 1}

LSU 2

LSU 3

LSU 4

LSU 5 $30^{\circ} 04^{\prime} 23.7^{\prime \prime}$

$30^{\circ} 04^{\prime} 42.6^{\prime \prime}$

$30^{\circ} 02^{\prime} 57.0^{\prime \prime}$

$30^{\circ} 02^{\prime} 06.0^{\prime \prime}$

$30^{\circ} 04^{\prime} 02.4^{\prime \prime}$ $91^{\circ} 58^{\prime} 55.5^{\prime \prime}$

$92^{\circ} 01^{\prime} 53.4^{\prime \prime}$

$92^{\circ} 00^{\prime} 25.5^{\prime \prime}$

$92^{\circ} 02^{\prime} 46.5^{\prime \prime}$

$92^{\circ} 03^{\prime} 15.3^{\prime \prime}$

SWEET LAKE

$30^{\circ} 02^{\prime} 37^{\prime \prime}$

$30^{\circ} 00^{\prime} 04^{\prime \prime}$

$30^{\circ} 01^{\prime} 16^{\prime \prime}$

$30^{\circ} 00^{\prime} 50^{\prime \prime}$

$30^{\circ} 01^{\prime} 05^{\prime \prime}$

$30^{\circ} 03^{\prime} 34^{\prime \prime}$

$30^{\circ} 02^{\prime} 16^{\prime \prime}$

$29^{\circ} 59^{\prime} 33^{\prime \prime}$

ROCKEFELLER REFUGE

$\mathrm{BCH}$

LEV

SHR

PLR

ALP

GCS

WRD

HQS $29^{\circ} 40^{\prime} 38^{\prime \prime}$

$29^{\circ} 42^{\prime} 43^{\prime \prime}$

$29^{\circ} 42^{\prime} 25^{\prime \prime}$

$29^{\circ} 41^{\prime} 14^{\prime \prime}$

$29^{\circ} 43^{\prime} 13^{\prime \prime}$

$29^{\circ} 44^{\prime} 05.3^{\prime \prime}$

$29^{\circ} 43^{\prime} 52.42$ "

$29^{\circ} 44^{\prime} 31^{\prime \prime}$ $93^{\circ} 12^{\prime} 47^{\prime \prime}$

$93^{\circ} 08^{\prime} 02^{\prime \prime}$

$93^{\circ} 08^{\prime} 43^{\prime \prime}$

$93^{\circ} 10^{\prime} 56^{\prime \prime}$

$93^{\circ} 05^{\prime} 19^{\prime \prime}$

$93^{\circ} 07^{\prime} 41^{\prime \prime}$

$93^{\circ} 07^{\prime} 01^{\prime \prime}$

$93^{\circ} 05^{\prime} 17^{\prime \prime}$ $92^{\circ} 53^{\prime} 19^{\prime \prime}$

$92^{\circ} 52^{\prime} 54^{\prime \prime}$

$92^{\circ} 50^{\prime} 31^{\prime \prime}$

$92^{\circ} 50^{\prime} 00^{\prime \prime}$

$92^{\circ} 48^{\prime} 32^{\prime \prime}$

$92^{\circ} 53^{\prime} 54^{\prime \prime}$

$92^{\circ} 52^{\prime} 19.43^{\prime \prime}$

$92^{\circ} 52^{\prime} 27^{\prime \prime}$ 
Coast, the absolute values of computed magnitudes may not be valid. However, they do serve as good indicators of the relative size of events.

Magnitudes calculated for microearthquakes recorded at the three Louisiana networks indicate that all events have been small, with magnitudes less than 1.5. The exception to this is the magnitude 3.8 earthquake that occurred on 16 October 1983 to the northwest of the Sweet Lake prospect.

\section{Data Analys is}

Microseismic monitoring has never before been attempted in the Louisiana Gulf Coast area. The present microseismic networks associated with geopressured-geothermal well development are the first. The lack of instrumentally recorded seismic activity in the Gulf Coast has made interpretation of the recorded seismic signals difficult.

\section{Types of Signals}

Various signal sources have been tentatively identified through the course of this study. Geophysical exploration blasting accounts for much of the observed activity (Fig. 5) as does cultural noise, such as the movement of vehicles along nearby roads. Occasionally, at Rockefeller Refuge, periods of extremely regular seismic energy appear every 10 seconds in the form of short bursts of 3 to 4 seconds' duration (Fig. 5). The origin of these signals remains a mystery, although they do seem to roll across the network from a seaward direction, possibly indicating the source to be offshore; because of their extreme regular character, the signals are most likely man-made.

Apart from these signals, two other types of signals have been recorded by the three networks: type I, or body wave, events and type II, or surface wave, events. Type I events are classified as microearthquakes and typically are characterized by a P-wave arrival (primary compressional/dilatational), S-wave 


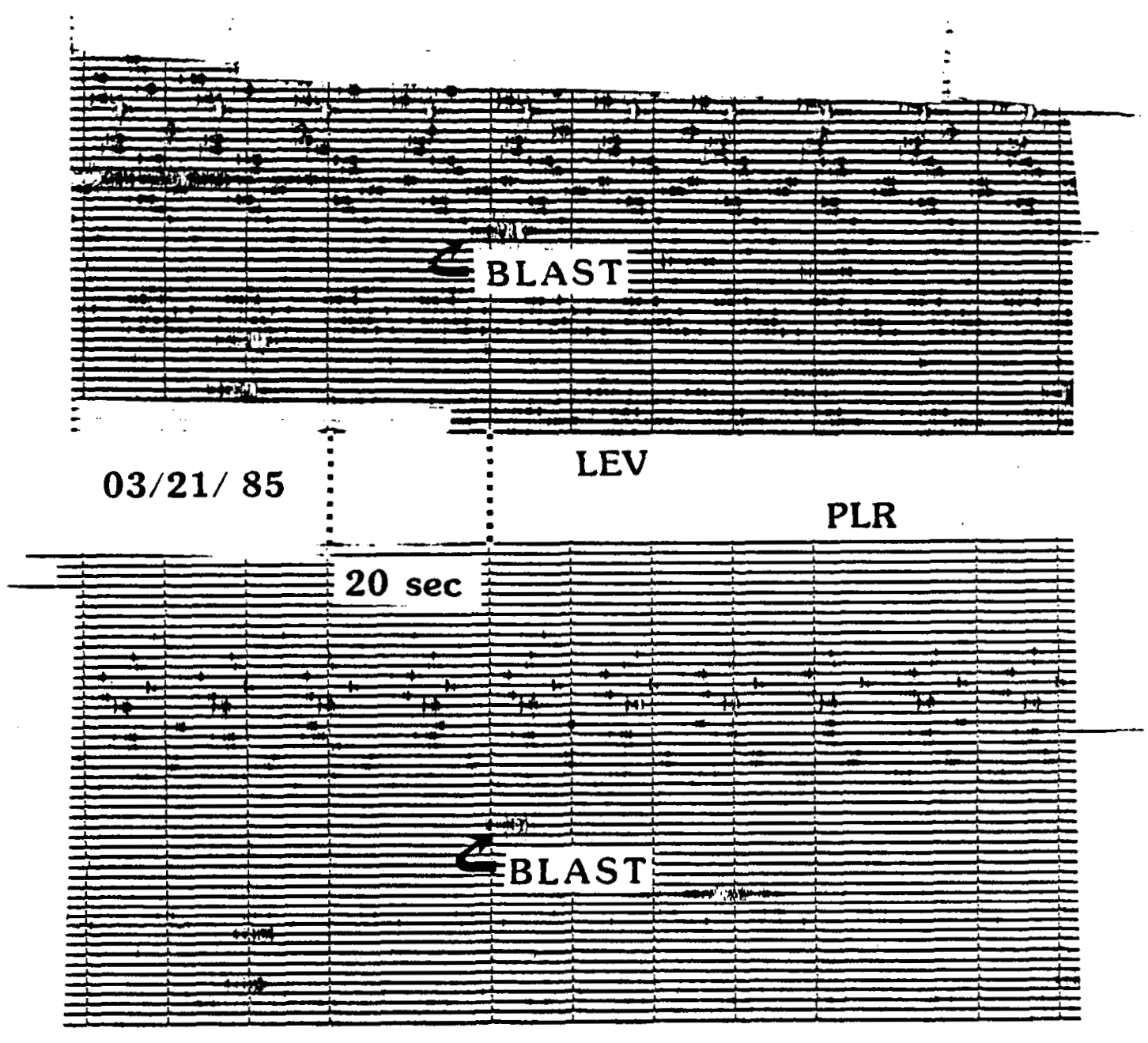

FIGURE 5. Regular type signals from Rockefeller Refuge network with geophysical exploration blast. 
arrival (secondary, shear waves) and, in some instances, a surface wave arriva). Type I events display P-wave velocities ranging from 1.5 to $6.0 \mathrm{~km} / \mathrm{s}$ (5000 to $20,000 \mathrm{ft} / \mathrm{sec}$ ) and contain seismic signatures typical of microearthquakes reported throughout the world (Fig. 6).

Type II, or impulsive Rayleigh wave, events are signals consisting entirely of surface (Rayleigh) waves. They are characterized by an impulsive first arrival and usually occur as bursts of activity 0.5 to 4 hours long. The apparent velocity with which these events traverse the networks is essentially sonic $(0.35 \mathrm{~km} / \mathrm{s}$, or $1150 \mathrm{ft} / \mathrm{s})(F i g .7)$. This velocity, in addition to its sonic characteristics, is similar to velocities of fundamental mode Rayleigh waves derived for a portion of the Gulf Coast in Texas. Because the sediment velocities in southern Louisiana are similar to those in coastal Texas, the initial conclusion was that these recorded arrivals may be fundamental mode Rayleigh waves originating from local microseismic activity (Mauk, 1983). Mauk (1984) also suggested that the type II events may be attributed to leaking energy from microearthquakes within a near-surface low-velocity layer, which would tend to trap the seismic energy within it. However, the frequency and velocity range of the type II events is also occupied by acoustical transmissions through the air (thunder or sonic booms), and significant coupling of atmospheric acoustic and earth Rayleigh waves is very common.

Currently, over 1000 microearthquakes have been reported at all three networks. Only 13 of these are classified as type I events; the rest are type II events. Many of the type II events have been attributed to well production and postproduction periods at Parcperdue and Sweet Lake prospects (Mauk, 1983; Agnew and Statton, 1984). Figure 8 shows the temporal distribution of suspected seismic events in relation to well production at the Parcperdue facility (Mauk, 1984). Based on this figure, type II events seem to show a correlation to production and postproduction periods at Parcperdue. Because of the 
14:46.20.0 UCT (UNCORRECTED)
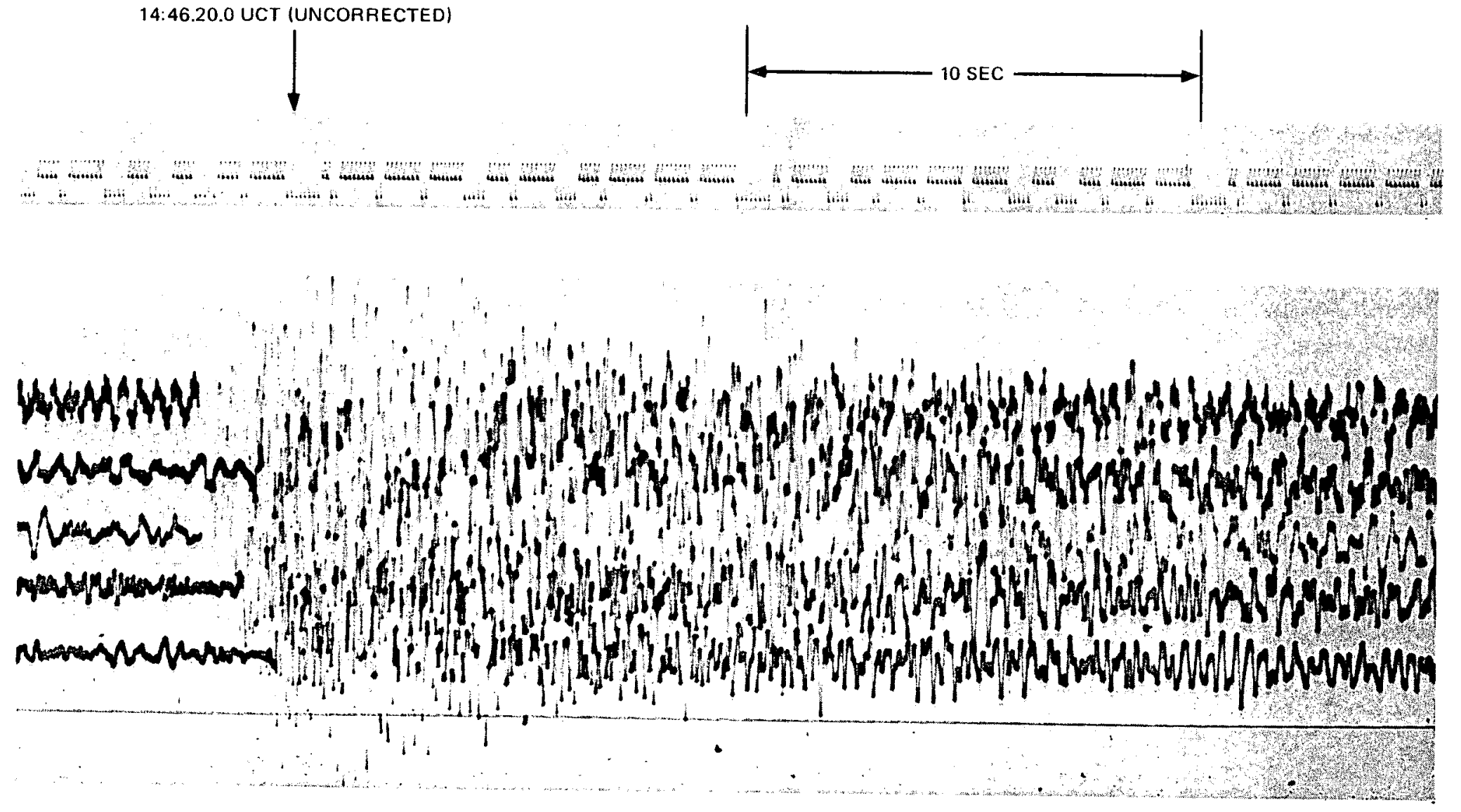

FIGURE 6. Type I event, Parcperdue network. 


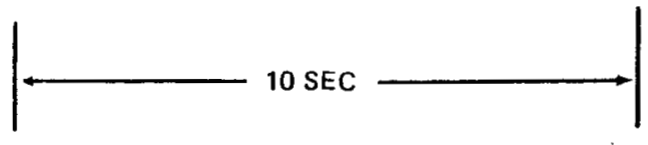

1

\section{guring}

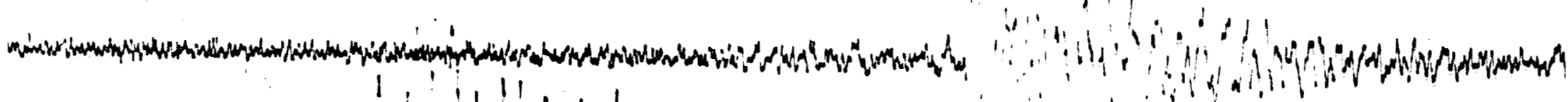

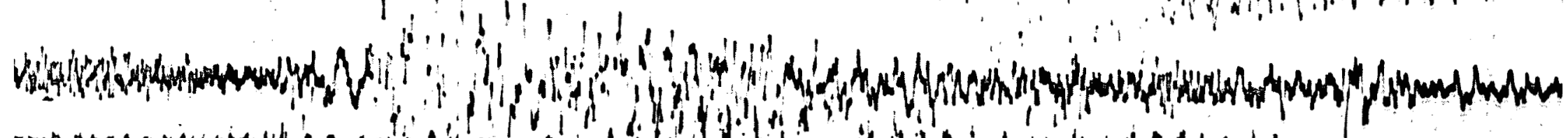

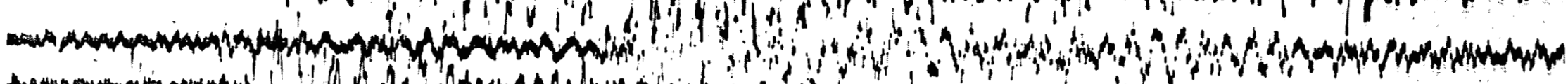
A

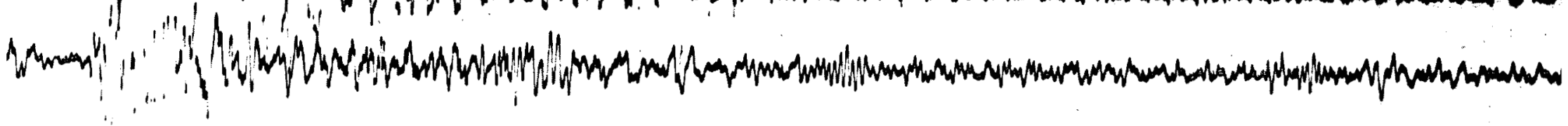

FIGURE 7. Type I I event, Parcperdue network. 


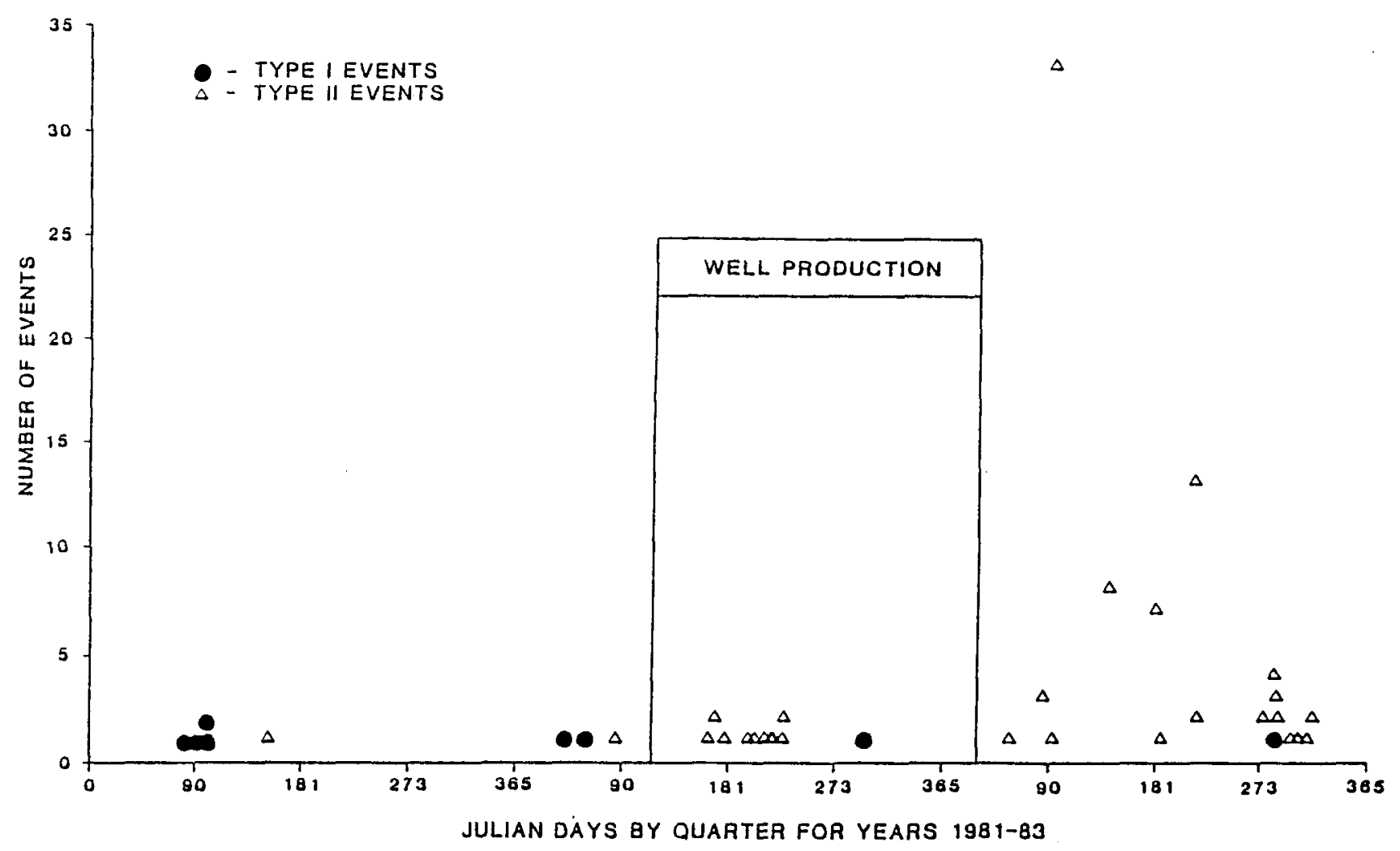

FIGURE 8. Distribution of seismic events and well production at Parcperdue. 
implications associated with coproduction and postproduction seismicity, it is of the utmost importance to determine if the observed impulsive Rayleigh wave events are of atmospheric or earth origin.

Type II Microearthquakes

In our 1982-83 annual report, an attempt was made to determine the origins of the type II events by correlating them with weather-related phenomena near each network. Comparison of daily rainfall from weather stations closest to each network showed a correlation only at Sweet Lake; however, it was far from conclusive. At Parcperdue and Gladys McCall the correlation was even more questionable. We found two problems in using daily rainfall data: (1) the occurrence of rain did not necessarily entail accompanying thunder and lightning and (2) very specific times could be pinpointed for suspected microearthquakes, but no specific time could be assigned to periods of rainfall. Data from weather stations were usually taken once in a 24-hr period. We found that the most accurate localized weather-related data could be obtained from hourly radar summary charts prepared by the National Weather Service office at Lake Charles, Louisiana (Fig. 1). The radar summary charts do not necessarily record thunder and lightning strikes, but they do indicate areas and intensity of rainfall and probable thunderstorms within a 400-km (250-mi) radius of Lake Charles. This radius easily encompasses the three geopressured-geothermal design wells.

Comparison of events recorded throughout the Parcperdue monitoring program with available radar summary charts indicates an extremely strong correlation to thunderstorm activity near the Parcperdue recording network. Between January 1981 and August 1983, only 2 of 98 reported type II events did not correlate with thunderstorm activity. In each instance when type II earthquake 
activity began, thunderstorms were moving close to or over the network. The type II events would then abate as the thunderstorms moved away or dissipated. On 28 June 1983, a series of seven type II events were reported in a 32min period between 0130 and 0202 UTC (universal time, coordinated). Figures 915 show the hourly progression of a thunderstorm as it approached the Parcperdue microseismic monitoring network from the north, continued south, and eventually dissipated over the Gulf of Mexico. The seven events occurred when the most severe portion of the storm was directly over the network (Fig. 13). The storm then moved off to the south (Figs. 14-15), and no further events were reported until 5 August 1983, which also coincides with thunderstorm passage.

On 30 March 1983 (Fig. 8, day 89), more than 35 type II events were reported between 0600 and 1900 UTC. This represents the largest and most intense period of activity reported throughout the Parcperdue monitoring program. Review of the hourly summary charts for this time period showed a large mass of thunderstorms moving over the Parcperdue seismic monitoring network during the entire time of reported type II seismic activity.

A strong correlation was also found in the records of seismicity at Sweet Lake and Rockefeller Refuge when they were compared to the meteorological records of Lake Charles. For the period of seismic data collection beginning in January 1981, a complete history of weather activity shows that days in which large numbers of small Rayleigh wave events were detected correspond very closely in time to thunderstorm activity in the area. This phenomenon was demonstrated on 17 April 1982. The largest single period of seismic activity reported throughout the Sweet Lake monitoring program, with over 63 type II events, occurred between 1200 and 1400 UTC on 17 April 1982. Again, review of hourly summary charts (Figs. 16-25) for this day and time shows that a mass of severe thunderstorms approached the network from the northwest at 1130 UTC (Figs. 16-19), passed directly over it between 1230 and 1330 UTC (Figs. 20-21), 


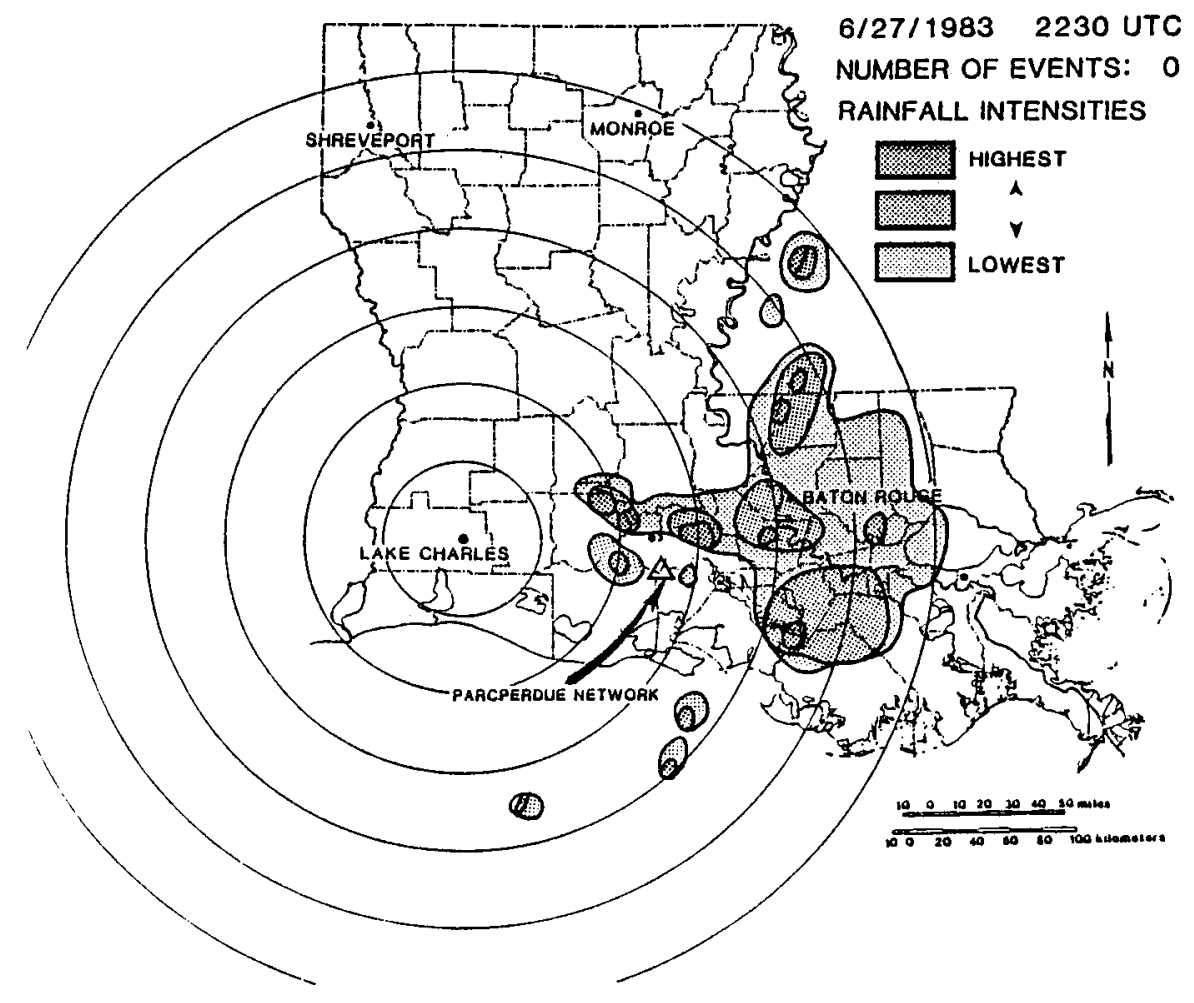

FIGURE 9. Lake Charles radar summary chart, 27 June 1983, 2230 UTC.

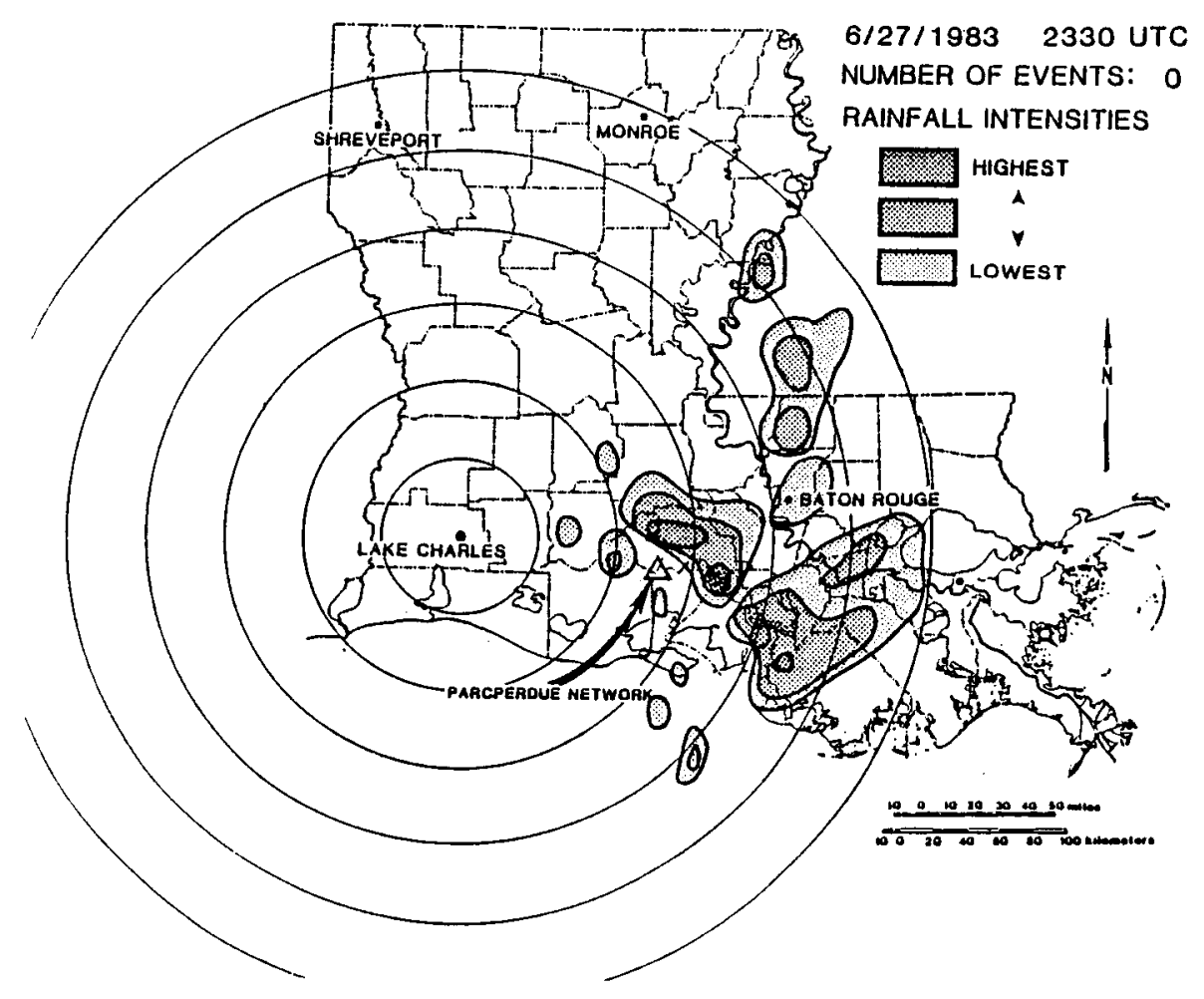

FIGURE 10. Lake Charles radar summary chart, 27 June 1983, 2330 UTC. 


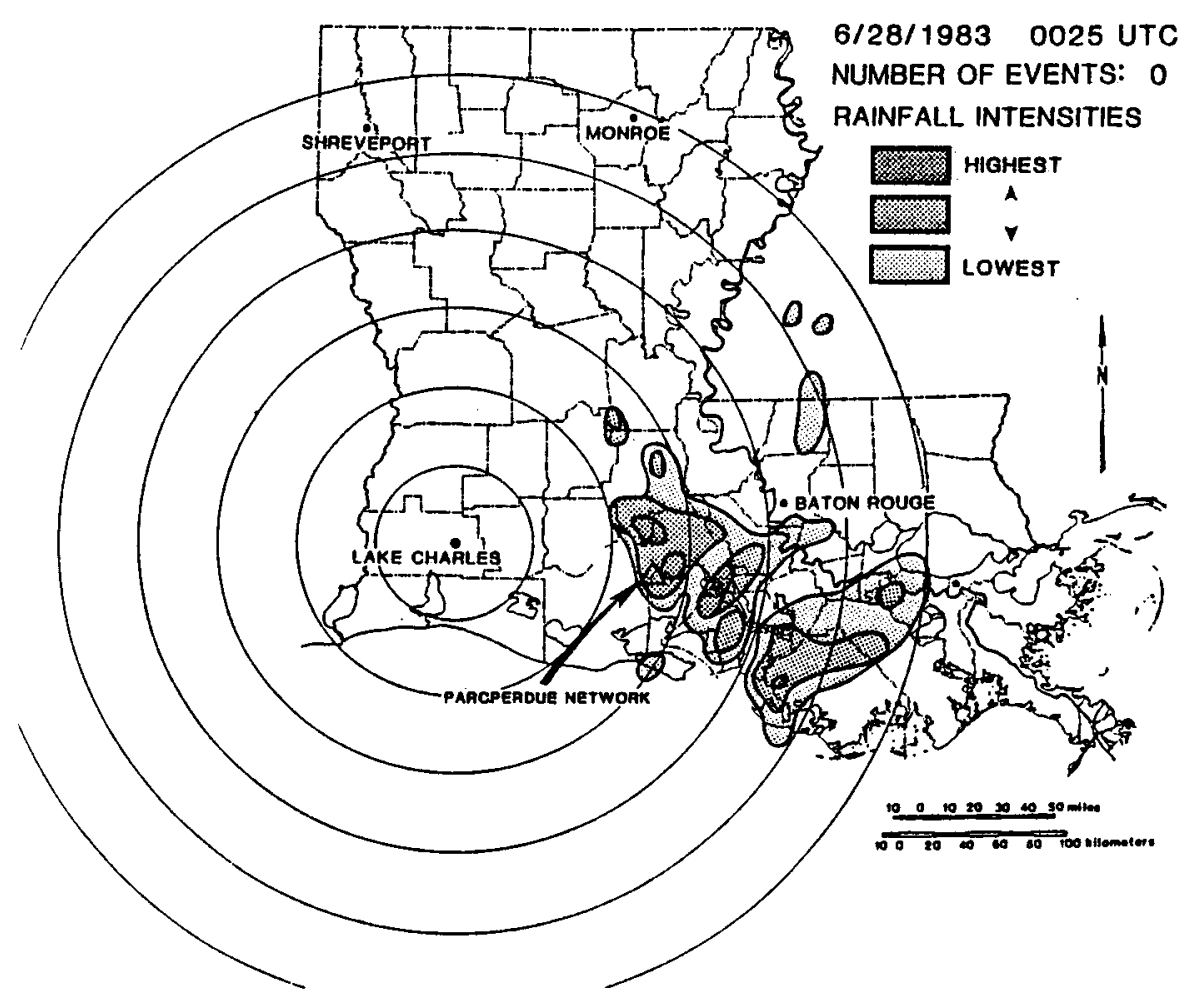

FIGURE 11. Lake Charles radar summary chart, 28 June 1983, 0025 UTC.

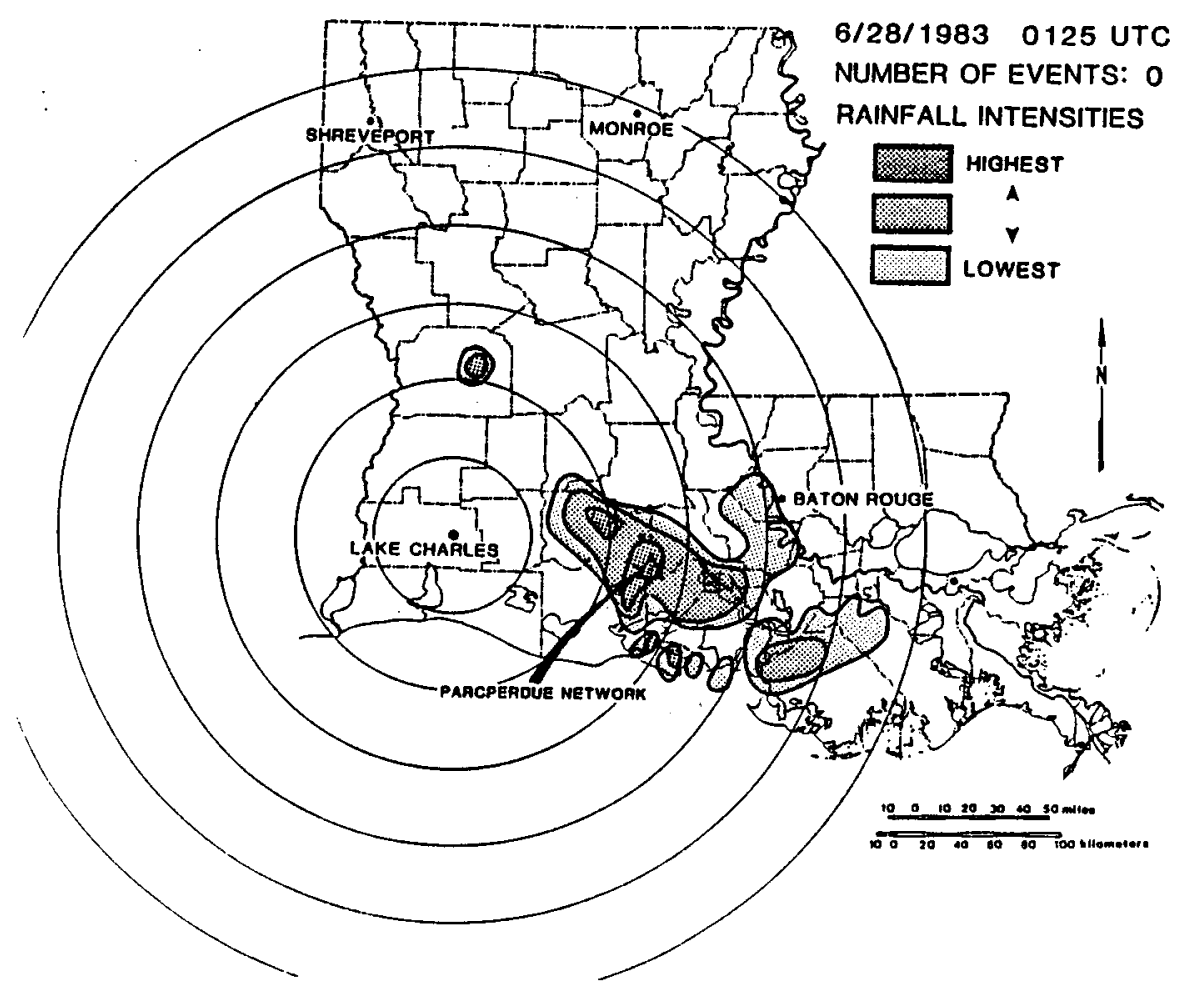

FIGURE 12. Lake Charles radar summary chart, 28 June 1983, 0125 UTC. 


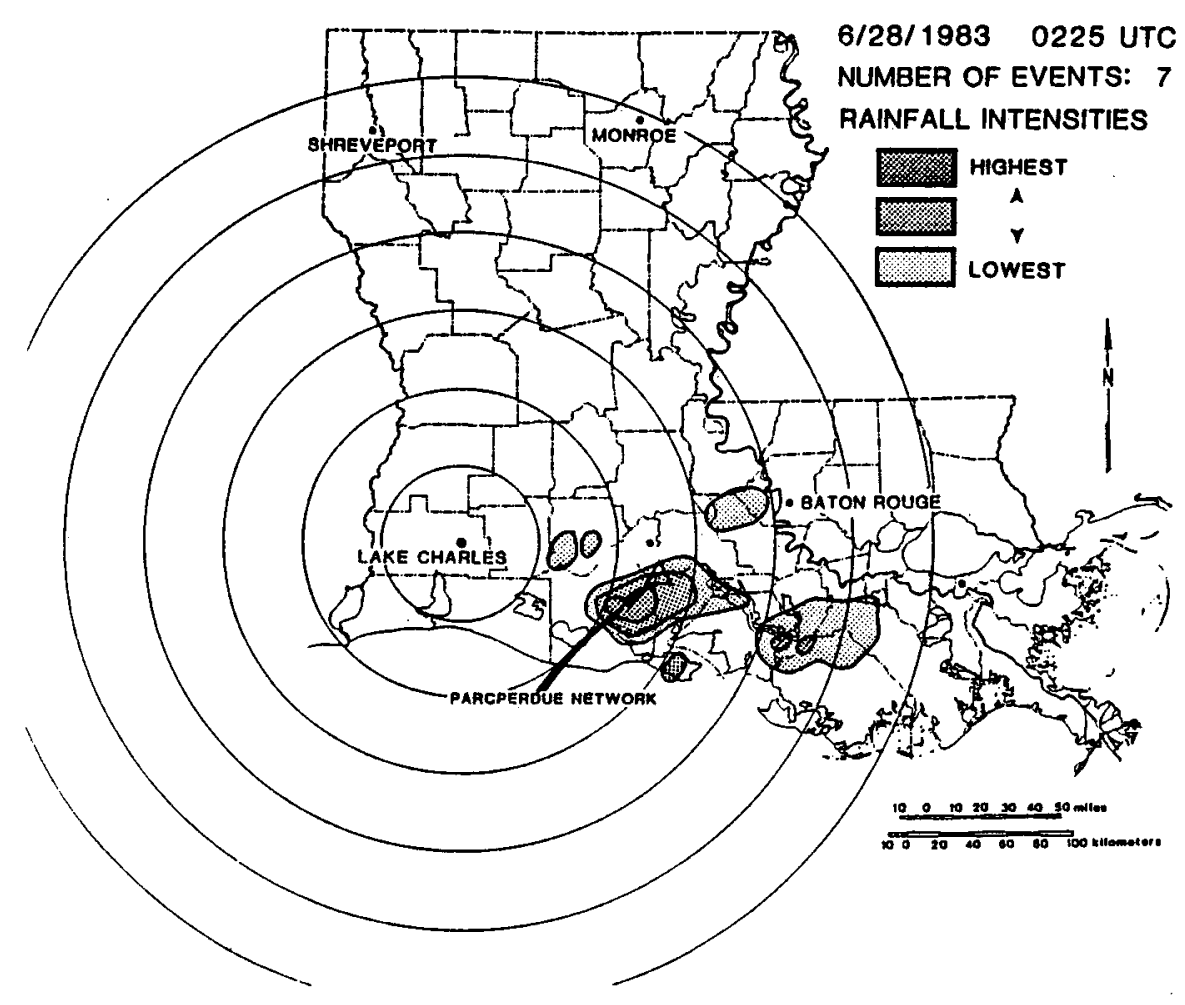

FIGURE 13. Lake Charles radar summary chart, 28 June 1983, 0225 UTC.

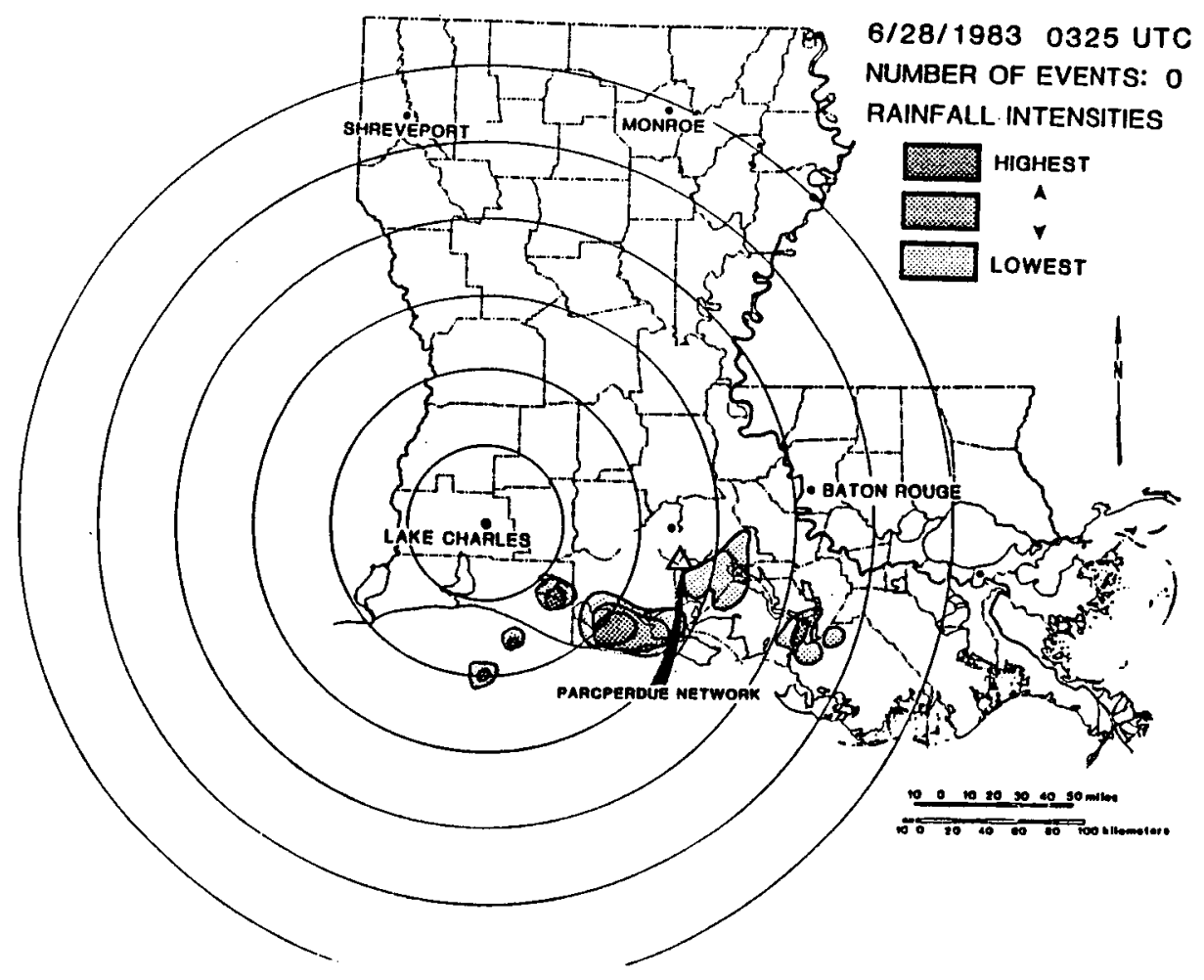

FIGURE 14. Lake Charles radar summary chart, 28 June 1983, 0325 UTC. 


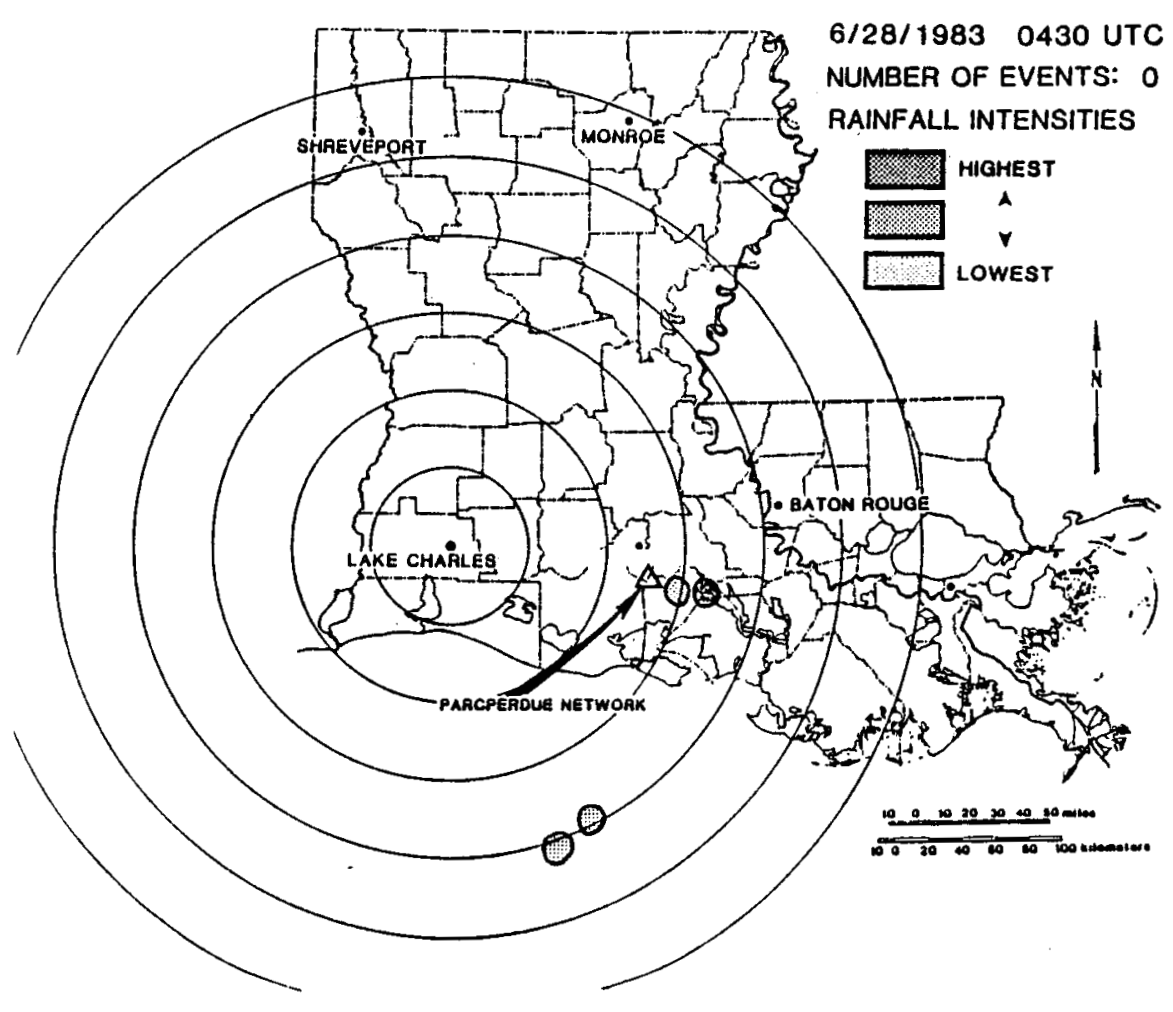

FIGURE 15. Lake Charles radar summary chart, 28 June 1983, 0430 UTC. 


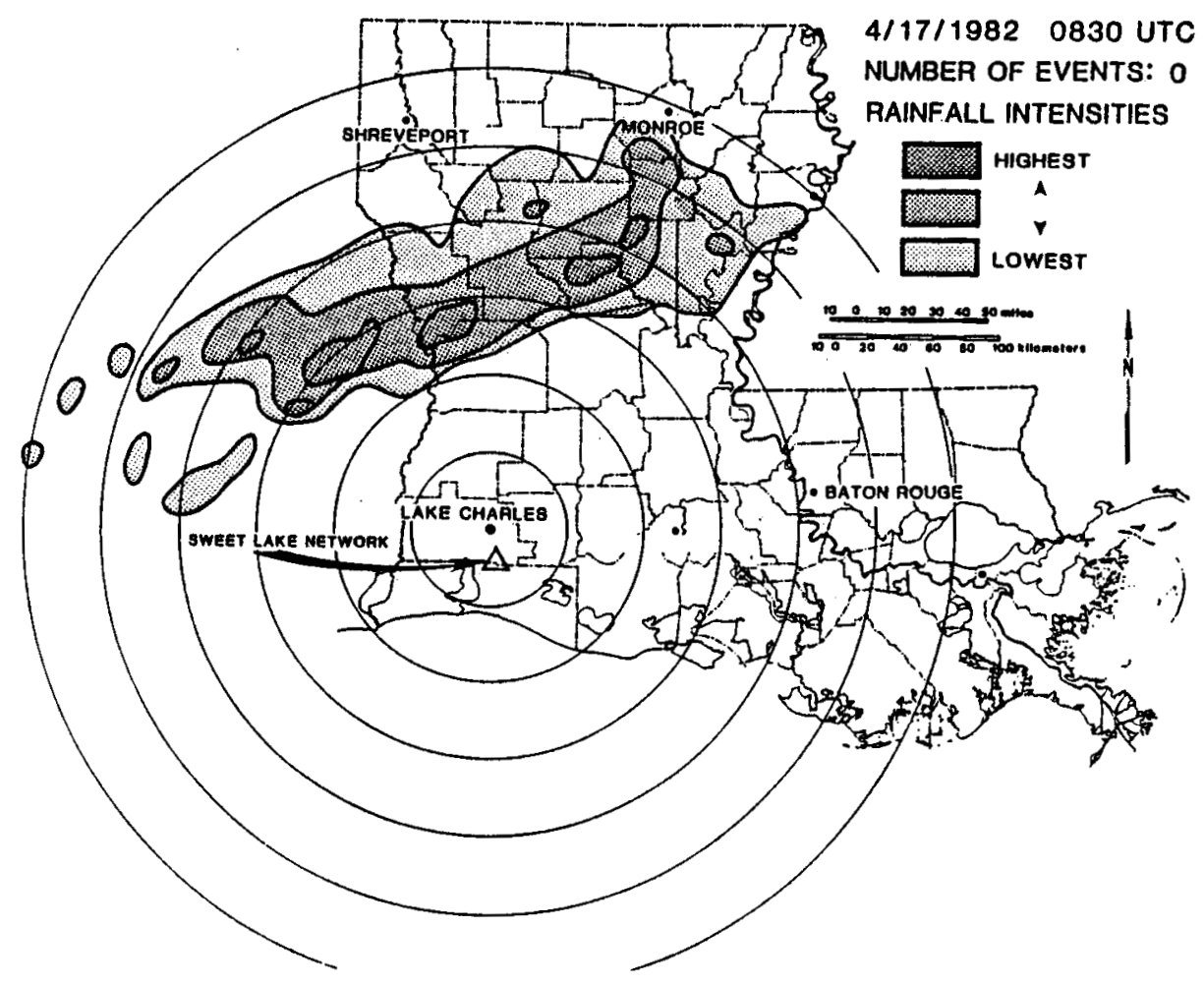

FIGURE 16. Lake Charles radar summary chart, 17 April 1982, 0830 UTC.

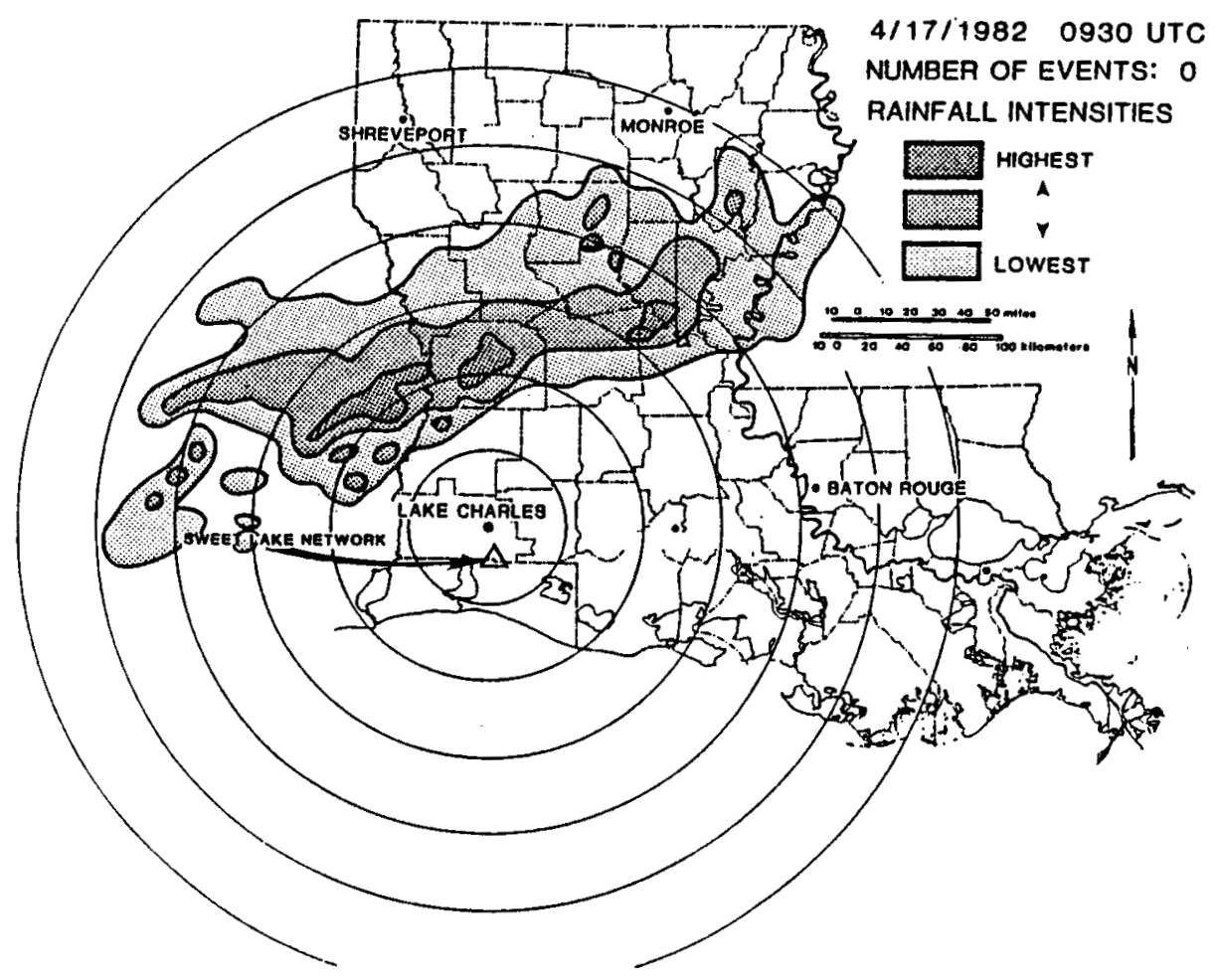

FIGURE 17. Lake Charles radar summary chart, 17 April 1982, 0930 UTC. 


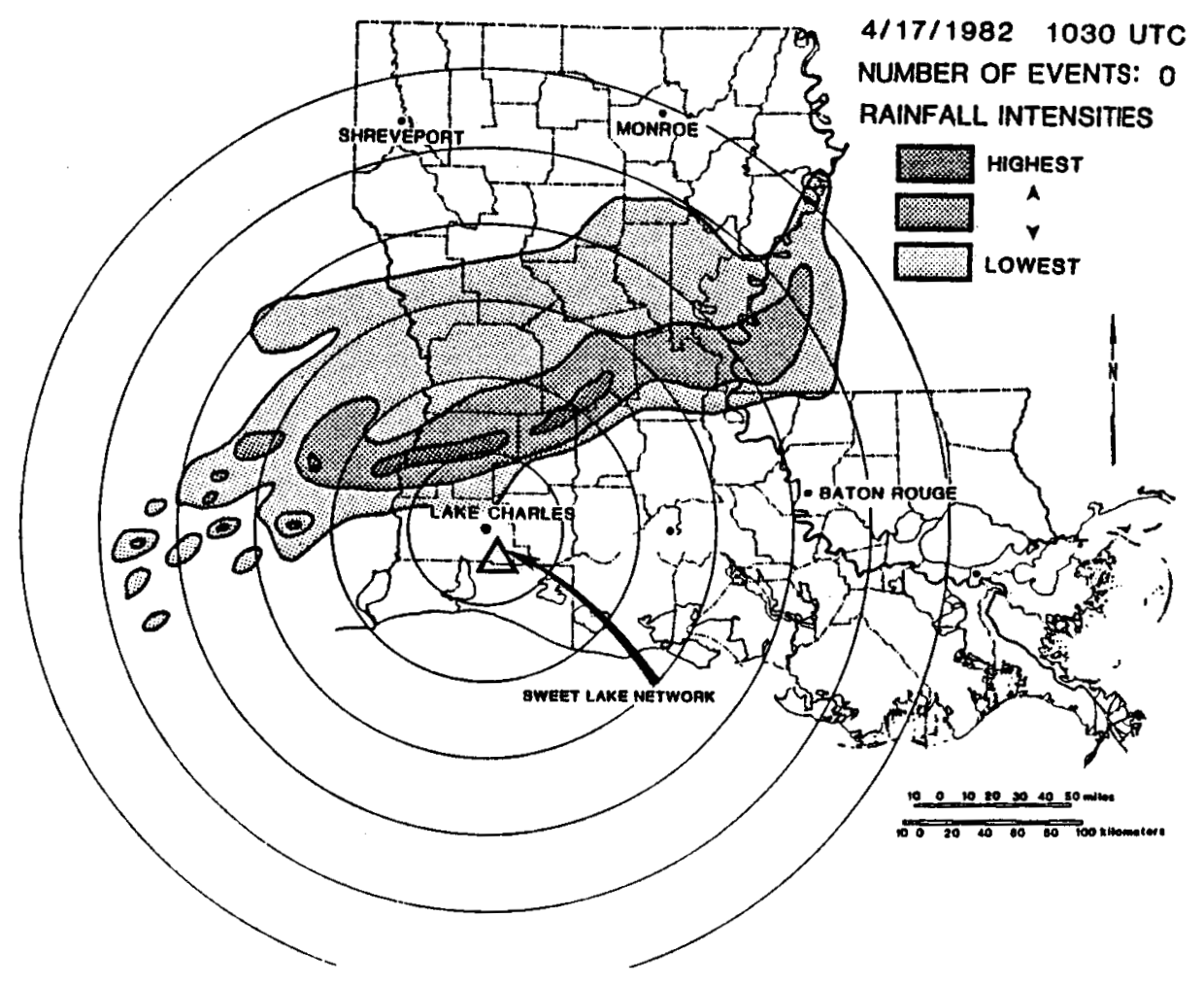

FIGURE 18. Lake Charles radar summary chart, 17 April 1982, 1030 UTC.

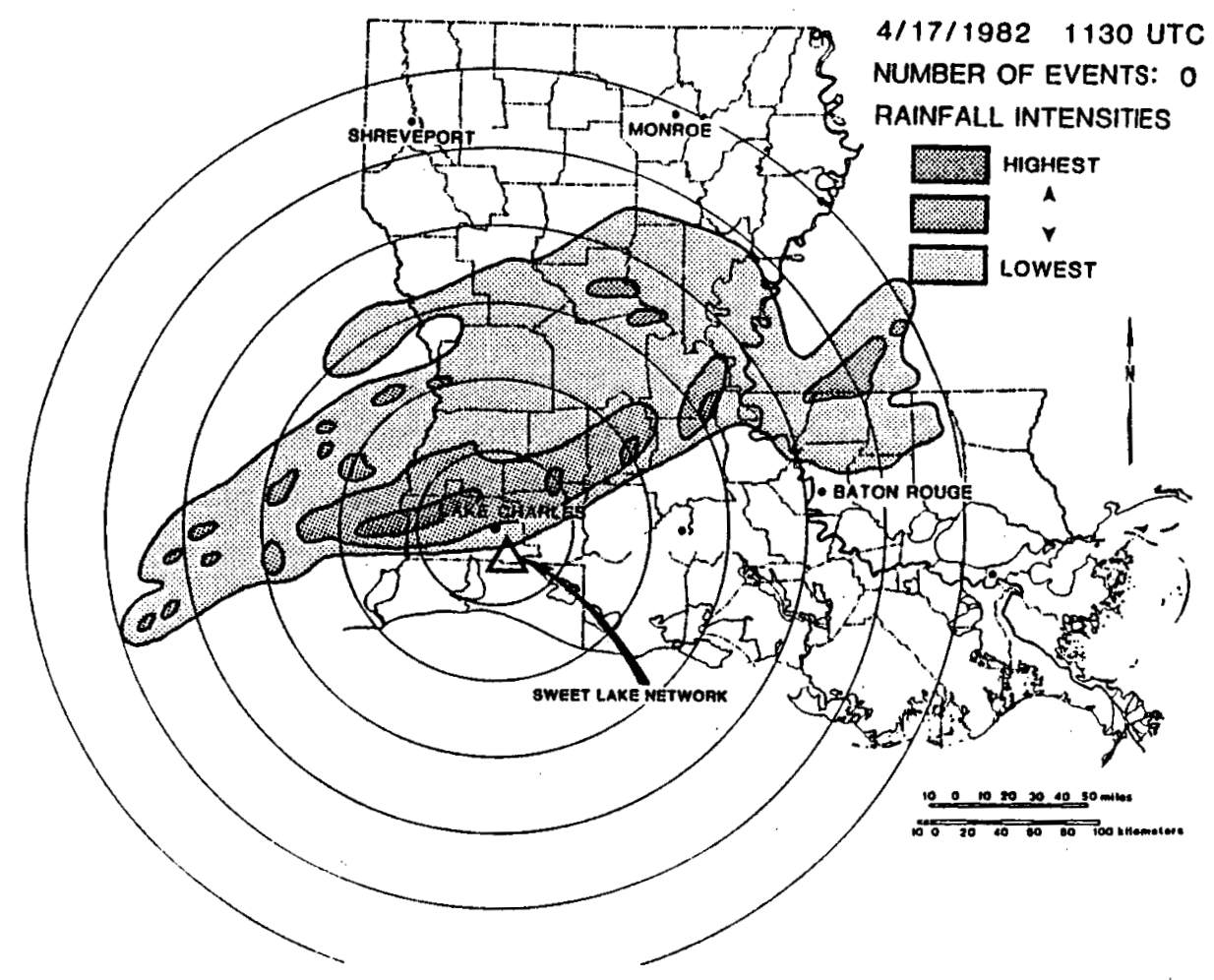

FIGURE 19. Lake Charles radar summary chart, 17 Apr il 1982, 1130 UTC. 


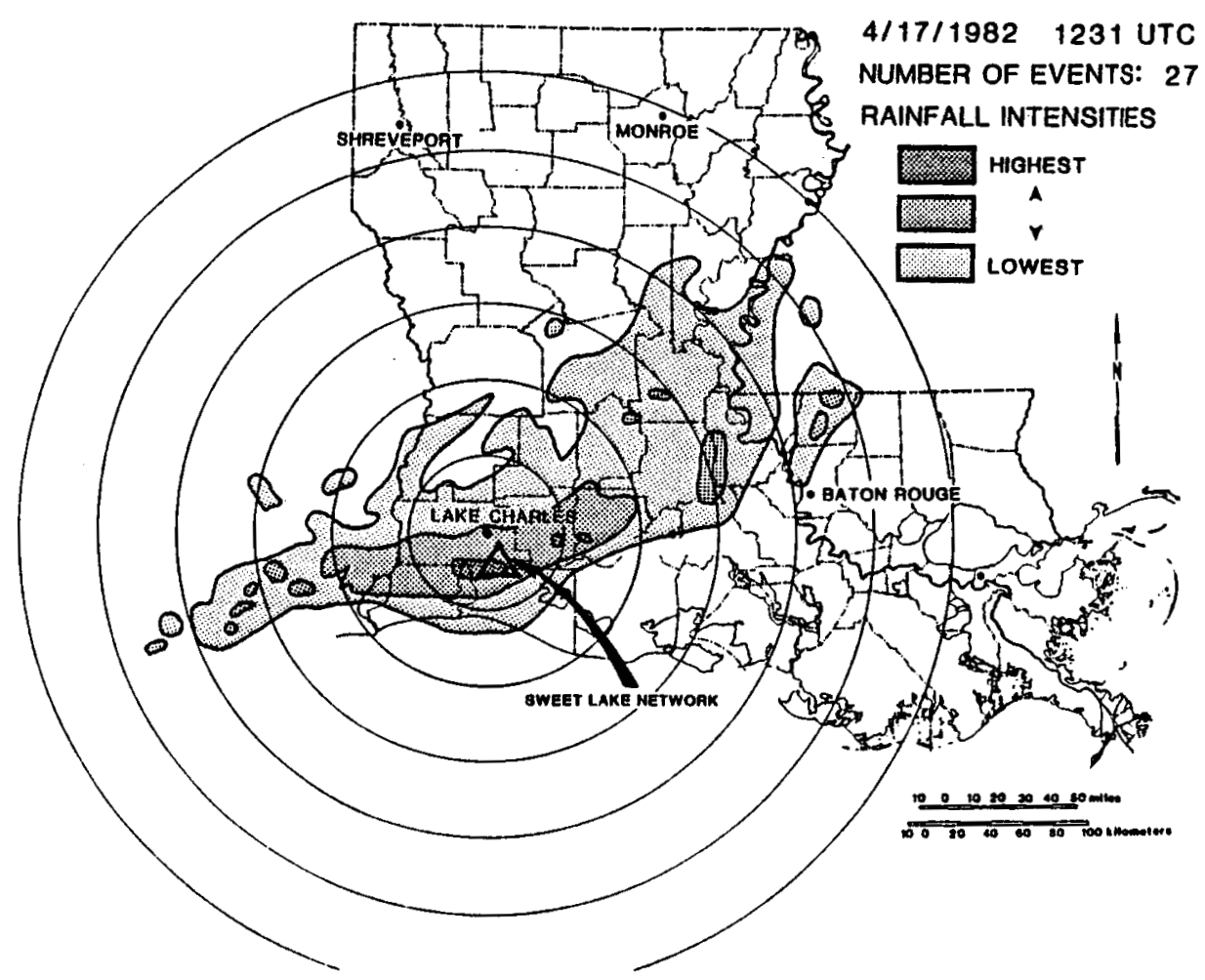

FIGURE 20. Lake Charles radar summary chart, 17 April 1982, 1231 UTC.

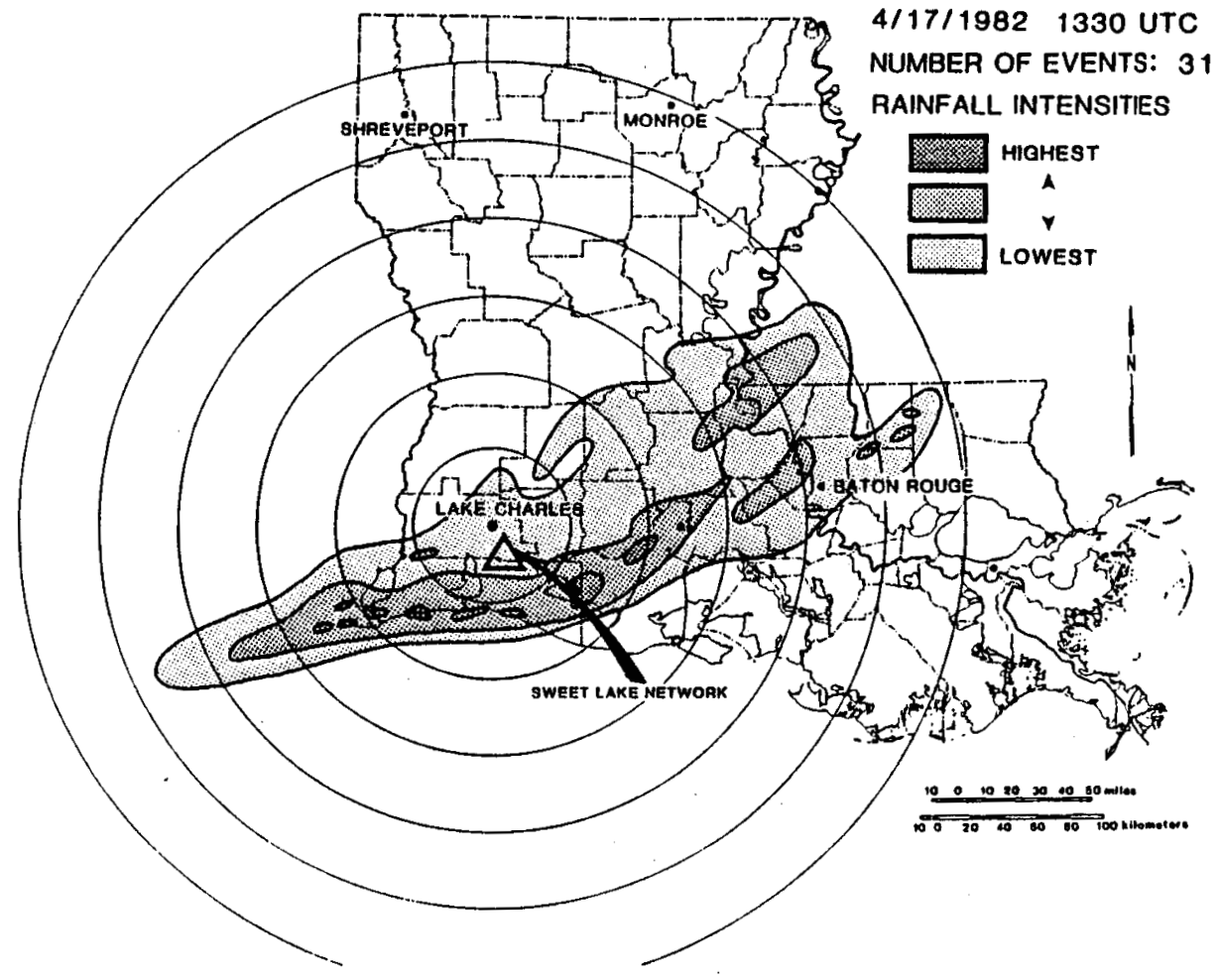

FIGURE 21. Lake Charles radar summary chart, 17 April 1982, 1330 UTC. 


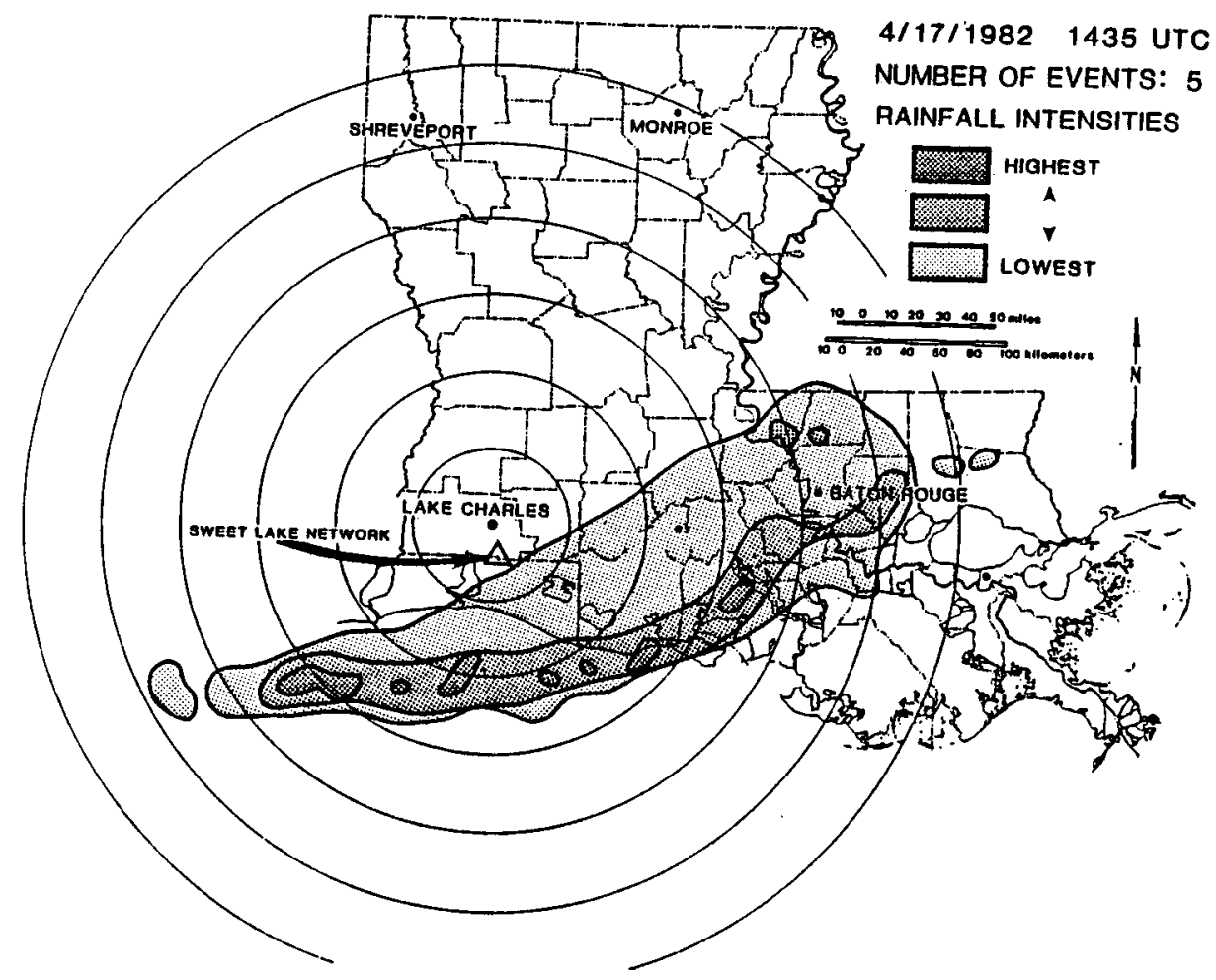

FIGURE 22. Lake Charles radar summary chart, 17 April 1982, 1435 UTC.

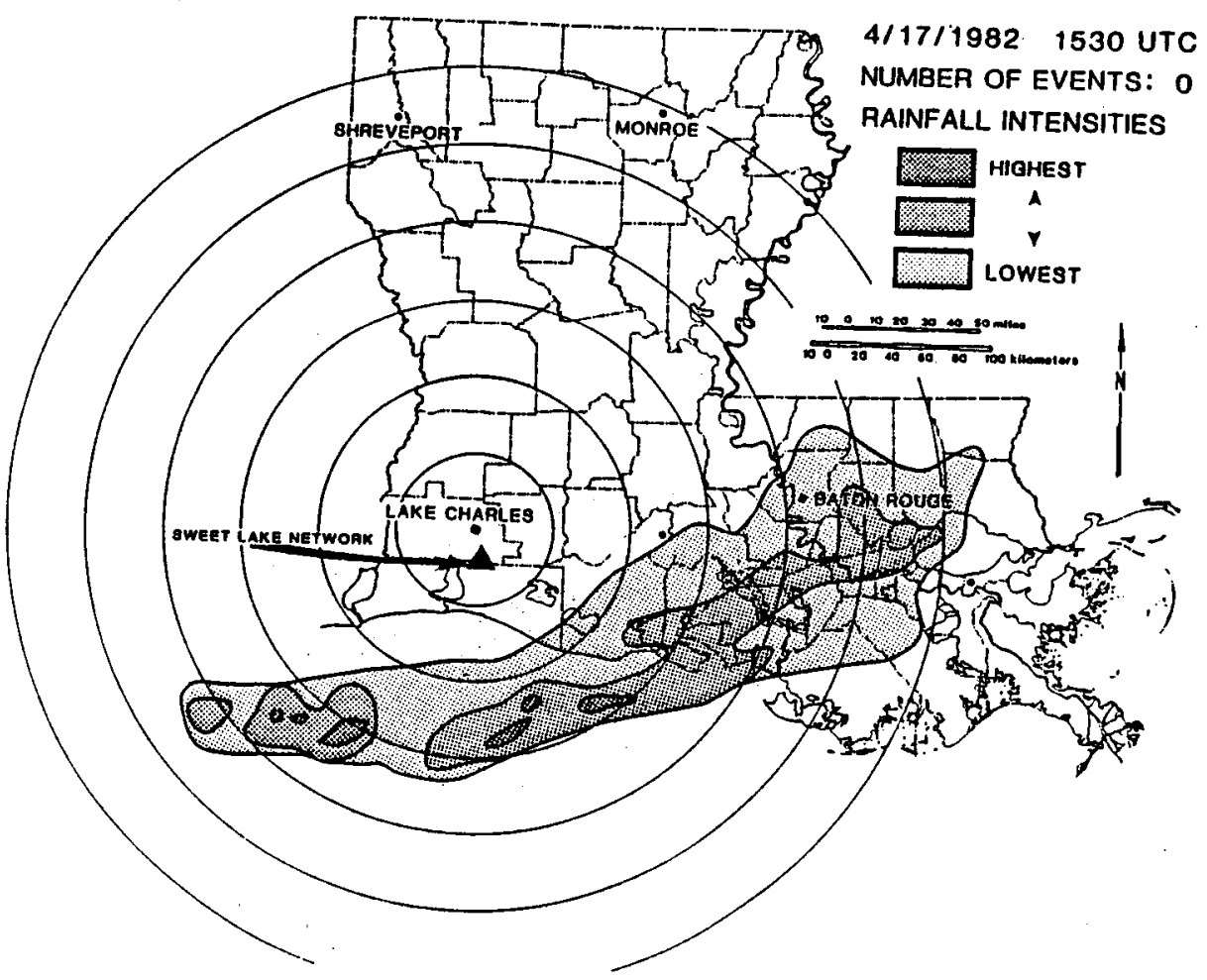

FIGURE 23. Lake Charles radar summary chart, 17 April 1982, 1530 UTC. 


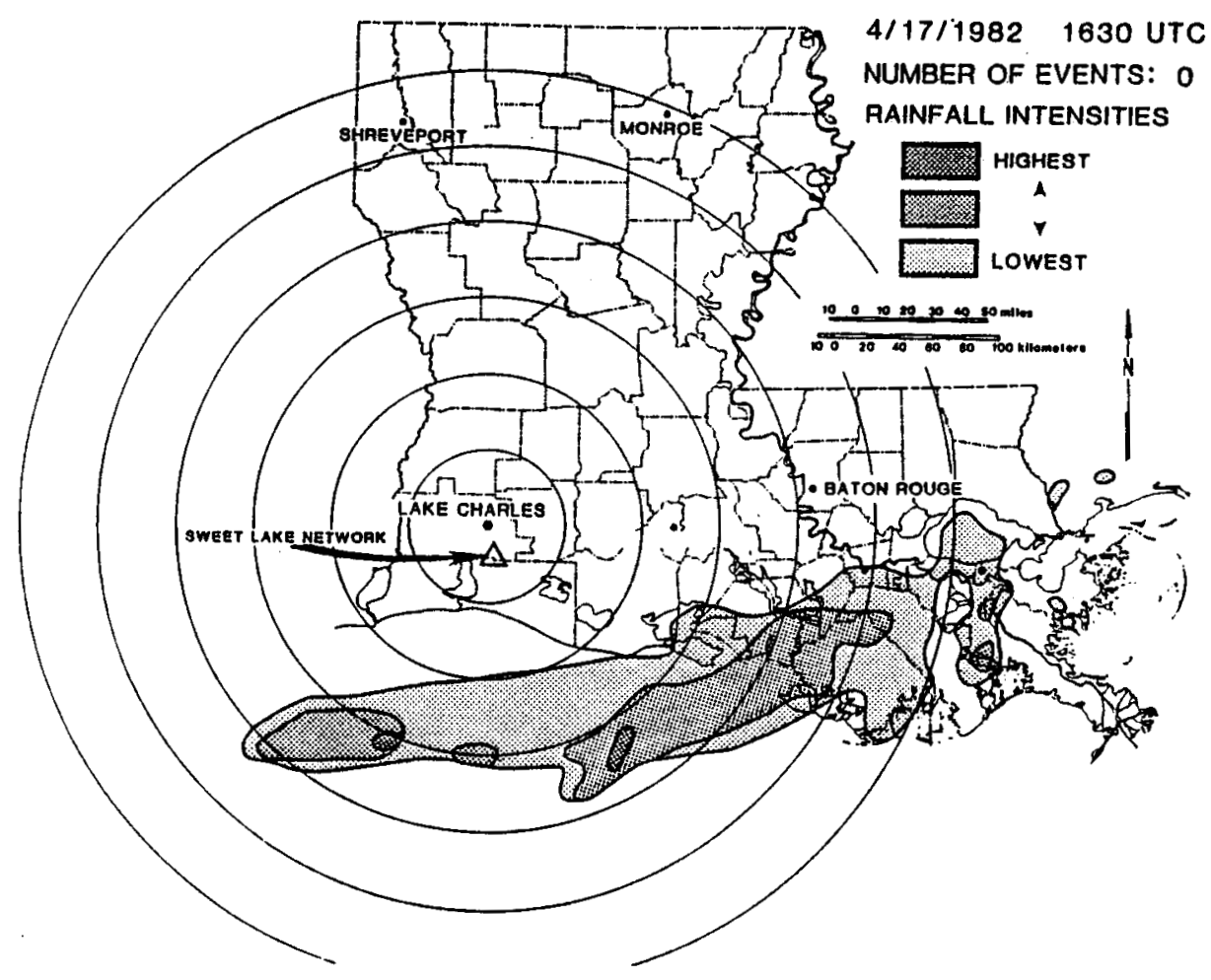

FIGURE 24. Lake Charles radar summary chart, 17 April 1982, 1630 UTC.

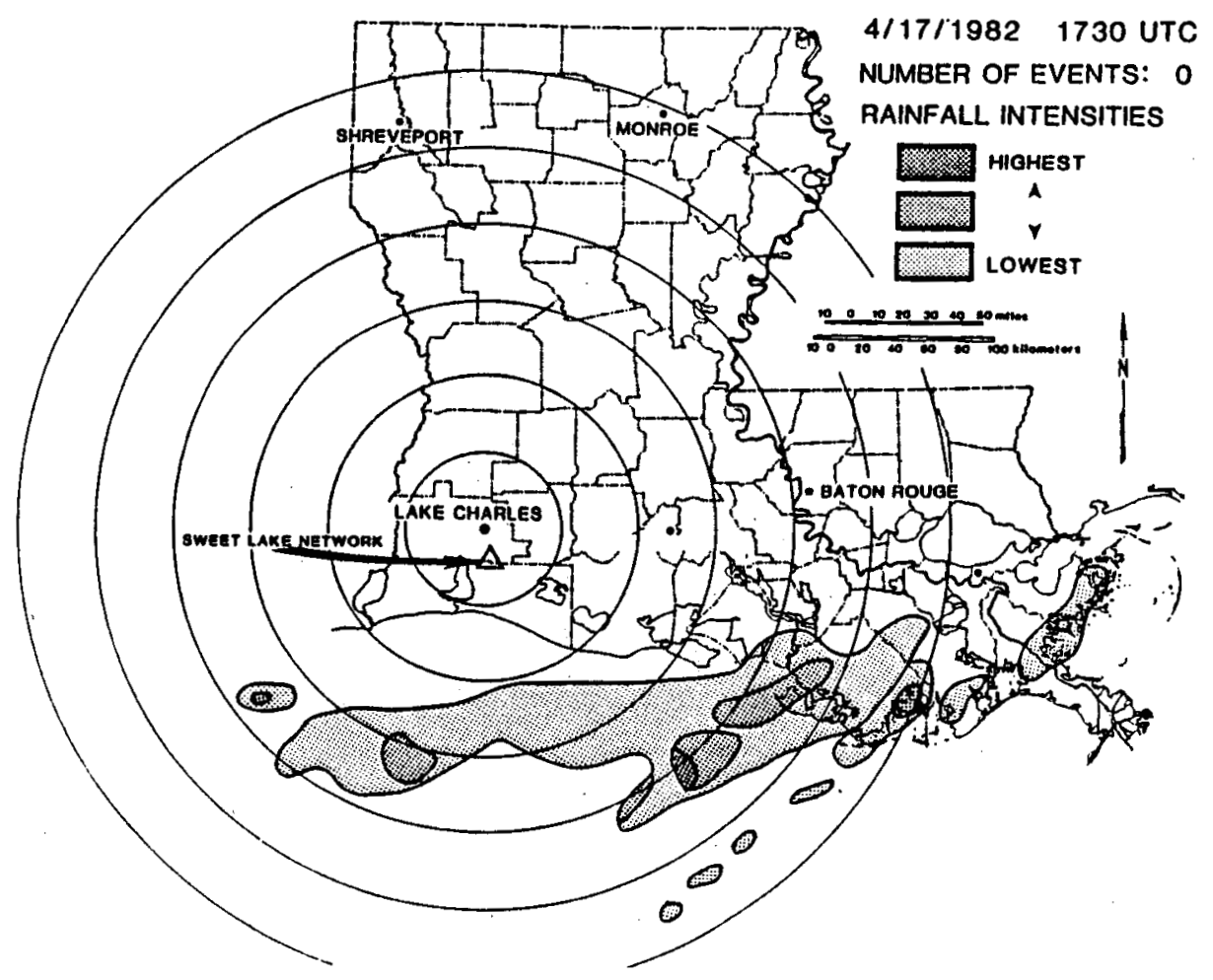

FIGURE 25. Lake Charles radar summary chart, 17 Apr il 1982, 1730 UTC. 
were well off to the southeast by 1430 UTC (Fig. 22), and were moving offshore by 1730 UTC (Figs. 23-25).

On days with good weather at Sweet Lake, Parcperdue, and Rockefeller Refuge, the type II events that have been observed are very few and appear to be traversing the network from origins far outside it. In the last two months of monitoring at Parcperdue, October and November 1983, several type II events were reported (Fig. 8). Unlike previous type II events, these have no thunderstorms associated with them. They appear as single events occurring intermittently with time. It is unclear, at this time, what the origin of these signals may be, but they are not thought to be caused by local earthquake activity. Possible explanations include sonic booms from military aircraft or surface waves from distant teleseisms.

\section{Type I Microearthquakes}

of the 13 type I microearthquakes recorded throughout the reporting period, 8 occurred within the Parcperdue network and 5 were within or near the Sweet Lake network.

The Parcperdue type I event locations are listed in Table 2 and shown in Figure 26, together with inferred locations of growth faults at a depth of $4900 \mathrm{~m}(16,000 \mathrm{ft})$ (Van Sickle and Groat, 1981). From the computed depths of $1800-6000 \mathrm{~m}(6000-20,000 \mathrm{ft})$ and locations, there seems to be a relatively close spatial relationship between type $I$ events and inferred growth fault locations. The degree of correlation is sufficiently high to assume that these events were the result of small movements along these growth faults. However, little or no well production was taking place when these events occurred.

Lake Charles event. The five type I events which occurred near the Sweet Lake network include the 16 October 1983 Lake Charles event, its associated foreshock of 11 September 1983, and the aftershocks of 4-5 December 1983 and 14 


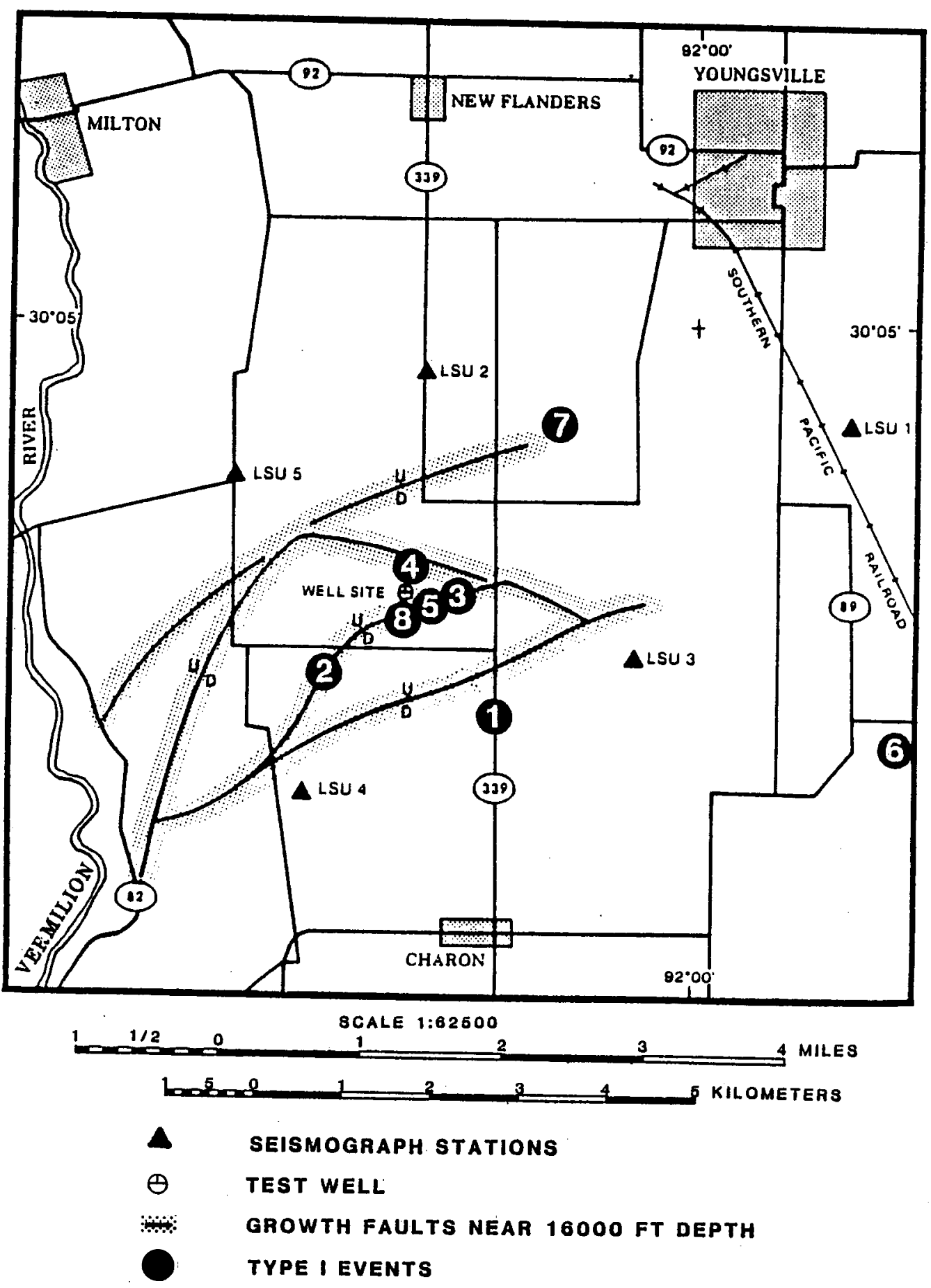

FIGURE 26. Locations of type I events, Parcperdue. 
TABLE 2. Type I events at Parcperdue.

\begin{tabular}{|c|c|c|c|c|c|}
\hline $\begin{array}{l}\text { Date } \\
(\mathrm{mo} / \mathrm{d} / \mathrm{yr})\end{array}$ & UTC & $\begin{array}{l}\text { North } \\
\text { Latitude }\end{array}$ & $\begin{array}{c}\text { West } \\
\text { Longitude }\end{array}$ & $\begin{array}{r}\text { Depth } \\
(\mathrm{km})\end{array}$ & Magnitude \\
\hline $3 / 27 / 81$ & 1748 & $30^{\circ} 02^{\prime} 31.0^{\prime \prime}$ & $92^{\circ} 02^{\prime} 44.2^{\prime \prime}$ & 2.0 & 1.3 \\
\hline $4 / 07 / 81$ & 1918 & $30^{\circ} 03^{\prime} 01.4^{\prime \prime}$ & $92^{\circ} 01^{\prime} 39.8^{\prime \prime}$ & 4.0 & 0.9 \\
\hline $4 / 11 / 81$ & 1914 & $30^{\circ} 03^{\prime} 23.2^{\prime \prime}$ & $92^{\circ} 02^{\prime} 30.0^{\prime \prime}$ & 4.0 & 0.8 \\
\hline $4 / 16 / 81$ & 0438 & $30^{\circ} 03^{\prime} 27^{\prime \prime \prime}$ & $92^{\circ} 02^{\prime} 13.0^{\prime \prime}$ & 1.0 & 0.5 \\
\hline $4 / 16 / 81$ & 1700 & $30^{\circ} 03^{\prime} 14.7^{\prime \prime}$ & $92^{\circ} 02^{\prime} 17.2^{\prime \prime}$ & 1.0 & 0.7 \\
\hline $2 / 26 / 82$ & 1446 & $30^{\circ} 02^{\prime} 29.7^{\prime \prime}$ & $91^{\circ} 59^{\prime} 28.1^{\prime \prime}$ & 1.55 & 1.5 \\
\hline $10 / 26 / 82$ & 1340 & $30^{\circ} 04^{\prime} 24.1^{\prime \prime}$ & $92^{\circ} 00^{\prime} 58.5^{\prime \prime}$ & 2.5 & -- \\
\hline $10 / 23 / 83$ & 1150 & $30^{\circ} 03^{\prime} 15.2^{\prime \prime}$ & $92^{\circ} 01^{\prime} 59.1^{\prime \prime}$ & --- & -- \\
\hline
\end{tabular}

January 1984. On 16 October 1983 at 1941 UTC an earthquake centered in the northwestern corner of the Sweet Lake seismic monitoring network occurred (Fig. 27, Table 3). The earthquake was recorded on seismograph instruments as far away as Ontario, Canada. The National Earthquake Information Service (NEIS) assigned it a magnitude of 3.8 .

Although no damage resulted, the earthquake was widely felt by many residents of Lake Charles, $12.8 \mathrm{~km}(8 \mathrm{mi})$ north of the epicenter. At our request, on 18 October the local Lake Charles newspaper, The American Press, ran a short article and questionnaire soliciting responses from citizens who may have felt the earthquake. As a result, we received over 200 responses from people throughout Lake Charles and the surrounding area. A sample of the questionnaire and three of the more interesting responses are presented in Appendix $A$. From these newspaper questionnaires, together with telephone and personal interviews, a detailed intensity survey was conducted.

The Louisiana Geological Survey's results indicated a maximum intensity of $V$ on a scale of I to XII for this earthquake (see Appendix B for the summary of intensities used in this evaluation). The results are plotted in figure 28. 


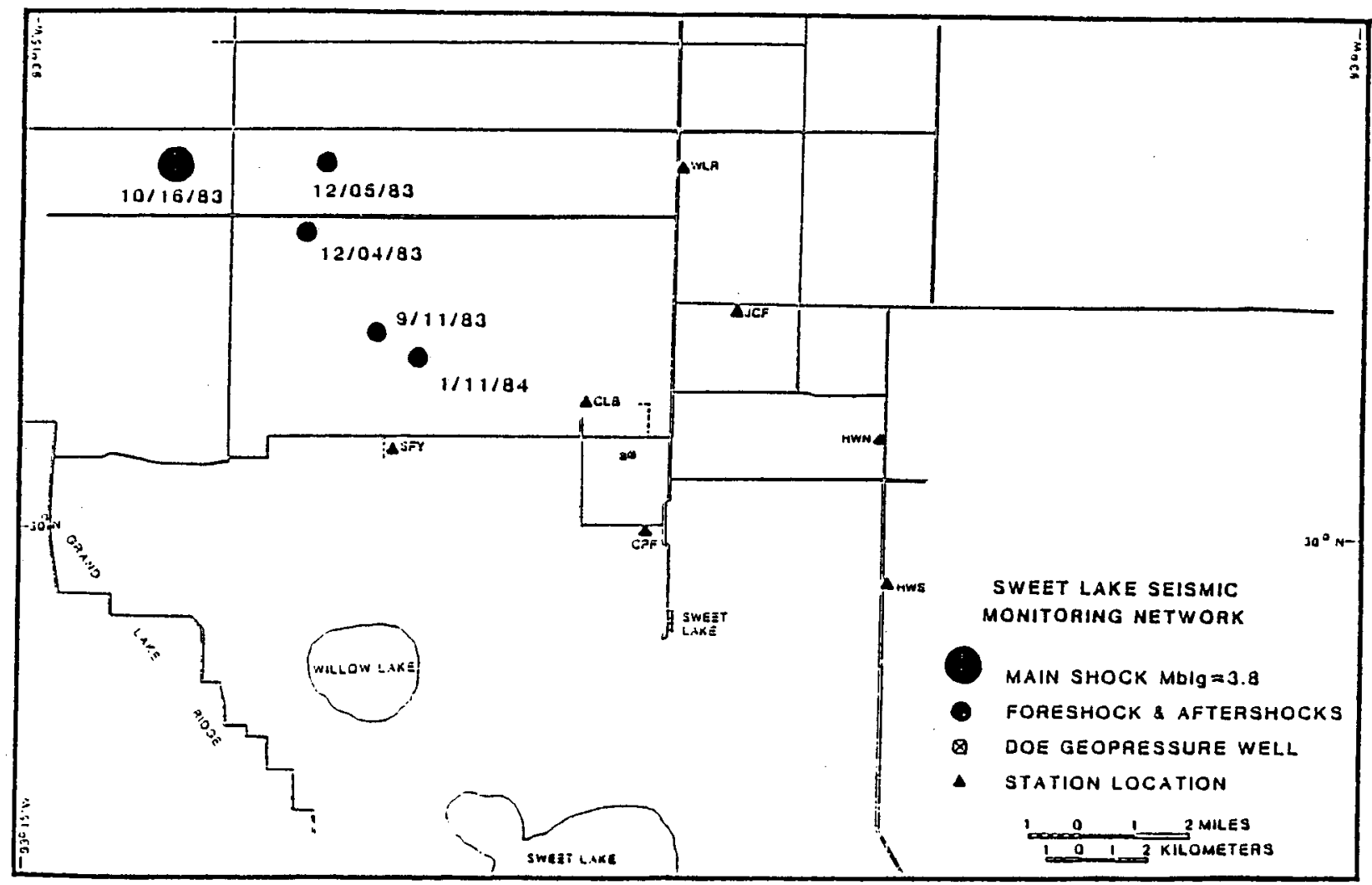

FIGURE 27. Locations of type I events, Sweet Lake. 


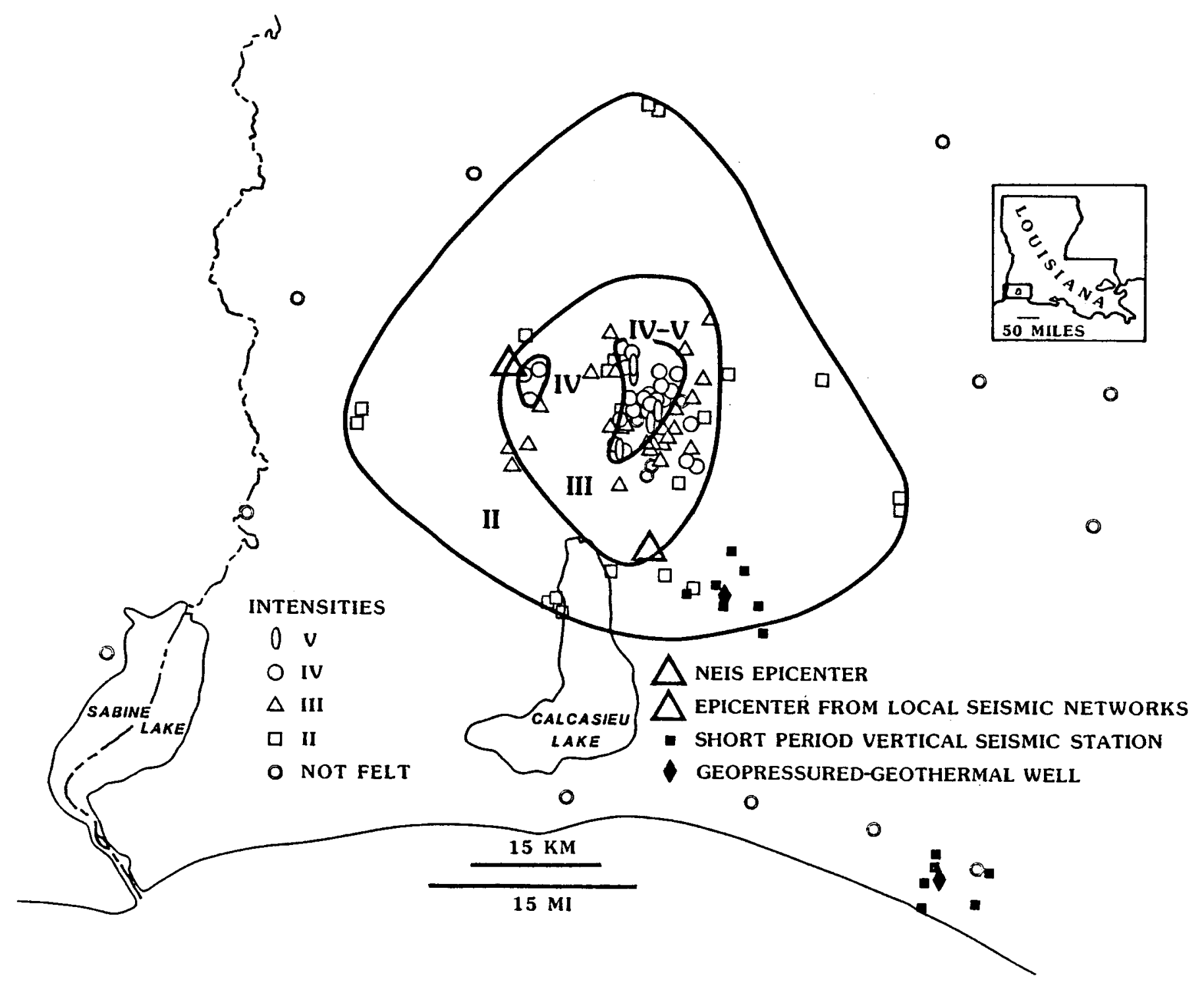

FIGURE 28. Isoseismal map, Lake Charles earthquake, 16 October 1983, magnitude 3.8. 
TABLE 3. Type I events at Sweet Lake.

\begin{tabular}{rllrrr}
\hline $\begin{array}{c}\text { Date } \\
(\mathrm{mo} / \mathrm{d} / \mathrm{yr})\end{array}$ & UTC & $\begin{array}{c}\text { North } \\
\text { Latitude }\end{array}$ & $\begin{array}{c}\text { West } \\
\text { Longitude }\end{array}$ & $\begin{array}{c}\text { Depth } \\
(\mathrm{km})\end{array}$ & Magnitude \\
\hline $9 / 11 / 83$ & 1551 & $30^{\circ} 00^{\prime} 26.28^{\prime \prime}$ & $9^{\circ} 11^{\prime} 07.08^{\prime \prime}$ & 8.32 &.-- \\
$10 / 16 / 83$ & 1940 & $30^{\circ} 03^{\prime} 30.60^{\prime \prime}$ & $93^{\circ} 13^{\prime} 24.24^{\prime \prime}$ & 12.62 & 3.8 \\
$12 / 04 / 83$ & 0350 & $30^{\circ} 05^{\prime} 30.48^{\prime \prime}$ & $93^{\circ} 14^{\prime} 44.52^{\prime \prime}$ & 7.85 & 1.4 \\
$12 / 05 / 83$ & 0445 & $30^{\circ} 06^{\prime} 05.76^{\prime \prime}$ & $93^{\circ} 15^{\prime} 53.28^{\prime \prime}$ & 7.29 & 0.7 \\
$1 / 14 / 84$ & 1848 & $30^{\circ} 01^{\prime} 35.04^{\prime \prime}$ & $93^{\circ} 11^{\prime} 22.92^{\prime \prime}$ & 11.22 & 0.7 \\
\hline
\end{tabular}

The NEIS epicenter and the epicenter from our local network are both shown, as are microseismic station locations and the Sweet Lake and Gladys McCall geopressured-geothermal we11 sites. Areas of highest intensity were located in the northern Lake Charles area. Isoseismals seem to radiate from the center of highest intensity showing no particular directional trend and covering a felt area of approximately $2500 \mathrm{~km}^{2}\left(1000 \mathrm{mi}^{2}\right)$. Several people reported directions of felt motion; however, no definite pattern could be determined from these accounts.

The isoseismal map shows that the epicenter plotted by the local networks is south of the area of highest intensity. Eleven stations in the Rockefeller Refuge and Sweet Lake microseismic monitoring networks were used to determine the earthquake's epicenter and depth of about $12 \mathrm{~km}(40,000 \mathrm{ft})$. The NEIS epicenter is located nearer to the area of highest intensity at a depth of $5 \mathrm{~km}$ $(16,000 \mathrm{ft})$. However, this location and depth is based on signals recorded over a broad regional area, with the closest instrument being greater than 100 $\mathrm{km}$ (60 mi) away from the epicenter. We believe that the southern location, based on our local networks, represents a more accurate indication of the true epicenter and depth. 
However, the southern location poses the following question: Why was the earthquake not felt as intensely in the epicentral area as it was $16 \mathrm{~km}$ (10 mi) to the north in Lake Charles? There are numerous growth faults throughout the Gulf Coast area, and many of the larger ones can be traced to great depths using seismic reflection surveys. One possible explanation for the discrepancies of felt intensities and epicenter location could be the channeling, from depth, of seismic energy up one of the area's larger growth faults to its surface extension some distance to the north, away from the actual epicenter.

In addition to the main event of 16 October, four other small events occurred which seem to be related to the main event. A small shock in the same general area preceding the main event occurred on 11 September 1983 (Fig. 27) and is interpreted as a foreshock. The three events of 5-6 December 1983 and 14 January 1984 (Fig. 27, Table 3) are most likely related aftershocks of the main event. The magnitudes of these additional events fall well below 1.0 , with depths between 8 and $10 \mathrm{~km}(26,000$ and 33,000 ft). The associated depths of this foreshock, main shock, and aftershock series would indicate activity far below any geopressured-geothermal producing horizon and may reflect movement in or near the crystalline basement.

\section{Seismicity and Well Production}

Production testing at Parcperdue began on 22 April 1982 and continued intermittently through 16 November 1982 (Fig. 8). The well was permanently shut in 5 February 1983. When all type II events are removed from consideration during this relatively short testing period, only one microearthquake was observed. It occurred on 26 0ctober 1982, the 183rd day of production after more than one million barrels of brine had been withdrawn. Event 8 on Figure 26 shows the location of this event, which was $2.5 \mathrm{~km}(8000 \mathrm{ft})$ deep. Since 
this is the only recorded coproduction event, there does not seem to be any significant seismic activity related to short-term testing at Parcperdue.

Sweet Lake had two major periods of production testing, the first from June 1981 through February 1982 and the second from November 1983 through March 1984. As in the Parcperdue case, when all suspected type II events are eliminated, no apparent seismic activity is associated with either period of Sweet Lake well production. The series of events associated with and including the 16 October 1983 Lake Charles event most probably cannot be attributed to any geopressured-geothermal producing horizon because of their relative depth of occurrence; moreover, production had not taken place for some 20 months prior to the event.

The Rockefeller Refuge test program has evolved into the most productive of the three prospects. Testing has been ongoing since November 1983 at average production rates of approximately 16,000 barrels of brine per day. Although many curious signals have been observed from the Rockefeller Refuge microseismic recording network, no credible microearthquakes have been correlated with production so far. Indeed, no local events have yet been recorded by the Rockefeller Refuge network.

\section{Summary}

Three years of microseismic monitoring data at the Parcperdue, Sweet Lake, and Rockefeller Refuge geopressured-geothermal prospects have displayed many different and curious signal characteristics. Two main signal types have been reported from all three networks. These include the type I, or body wave, events which more closely resemble microearthquakes reported from other areas of the world and type II, or Rayleigh wave, events that display characteristics more closely related to sonic waves. Type I events have been recorded at two of the three prospects, Sweet Lake and Parcperdue. Seismic activity occurring 
around Sweet Lake does not appear to be associated with geopressured-geothermal development; instead, this activity displays origins far below current or prospective geopressured-geothermal producing horizons. The type I events associated with Parcperdue display a probable correlation with suspected growth faults at depth; however, no credible evidence of coproduction seismicity exists. Type I activity is intermittent with most of the Parcperdue events occurring prior to production. Only one type I event took place during flow testing; one other event occurred a year after shut-in. With the use of highly localized weather data, there is strong evidence that almost all type II events are attributable to thunderstorm activity in the vicinity of each network.

When suspected atmospheric events are removed from consideration, there is no apparent correlation of seismic activity with geopressured-geothermal test well production so far. This does not seem so surprising when the short production histories and relatively small volumes of fluid produced at Parcperdue and Sweet Lake are considered. Long-term, high-volume testing, such as that being done at Gladys MCCall, will be the real test of whether microseismicity and growth fault activation can be induced by geopressured-geothermal development.

\section{References}

Agnew, J. D., and T. C. Statton, 1984, Microseismic monitoring of the Sweet Lake, Louisiana, Magma Gulf-Technadril/DoE/Amoco Fee No. 1 Geopressured/ Geothermal Energy Test Well Program, final report: №. 80C5030, 300 p.

Lee, W. H. K., and J. C. Lahr, 1975, HYP071 (rev.): A computer program for determining hypocenter, magnitude and first motion pattern of local earthquakes: U.S. Geo1. Survey Open-File Rept. 75-311.

Mauk, F. J., 1983, Microseismic monitoring of Bayou Parcperdue, Louisiana: Teledyne Geotech Tech. Rept. no. 83-2, 72 p. 
Mauk, F. J., 1984, Microseismic monitoring of Bayou Parcperdue, Louisiana: Teledyne Geotech Tech. Rept. no. 84-2, 70 p.

Van Sickle, V. R., and C. G. Groat, 1981, Subsidence and induced faulting: Key environmental issues in geopressured-geothermal resource development, in D. G. Bebout and A. L. Bachman, eds., Proceedings of the fifth conference on geopressured-geothermal energy, U.S. Gulf Coast: La. State Univ., Baton Rouge, p. 325-30. 
Short article in the 20 October 1983 issue of the Lake Charles American Press and three of the more detailed responses

\section{Data sought on SW La. earthquake}

The Louisiana Geological Survey office in Baton Rouge is looking for comments from persons who experienced any reaction to a small earth tremor that was recorded Sunday in the area south of Lake Charlea.

The tremor was registered at 2:40 p.m. Sunday about elght miles south of McNeese Slate University.

Donald Stevenson of the Baton Rouge office asked residents of the area south of Lake Charles to answer the following ques. tions "yes" or "no" and to mail the responses to: Loulslana Geological Survey, P.0. Box G, Baton Rouge, La. 70893, marked to Stevenson's attention.

- Did you feel the tremor?

Yes......No.....

- Were you inside a bullding?

Yes.....No.....

- Did It frighten anyone?

Yes.....No.....

- Any rattling of doors or windows?

Yes......No.....

- Did any objects swing Inside the bullding?

Yes......No.....

-Were there any overturned objects?

Yes......No.....

- Any vislble damage? Il so, explain.

Yes......No.....

- Give your locatlon (hlghway or streel number) or general locallon wilh respect to Lake Charles). 
1901 Core Ar.

Sulphur, zoa

70663

Qctoben20,1983

Lear Lir:

Around 2:40 pM Sunday, of felt the earthquake in South Lake Charles, d was on the second floor of the cheese state. "University Library (Mckee has a two -story "old" building and a 4-stery new additiona was in the old building). There were about six other people on the flow alar doing research. Within a 10-second pried, the entire building swayed back and forth (side to side) two full times. At that same moment, there was a large crashing sound as books on both sides of the floor, fell. Alas, some of the metal "bookends" rattled for a second a two." After this, everything was lack to normalafter we all looked around at each other with questions witter all over our faces. Lt concerned me quite a bit and $\&$ debated whether on not to leave the building - o remained.

If possible, coned you send me a pamphlet a something on this quake. I have beer interrested in earthquakes for years. Hope ot iva of help to your survey. sincerely,

-108- Derek W. Chaumont 
HilBert Mi. Landry 304 I volcano Sa.

Lake Charles, LA. 70605

GEO. SUrvey

On Dis

heard an radio you wake to hear from people that feet the' eathgerate last Sunday:

Myself, my infer and my sta all felt the shock. Hie rive in a frame house cen fin. We were ace in aide the house and the Phone shote very gard. Any wife was sleeking cont ir work her up. The bed cquakex. the thought it ware from a sic boom prince there war an cir shiv' in town, Tope this information wile
Pinckney

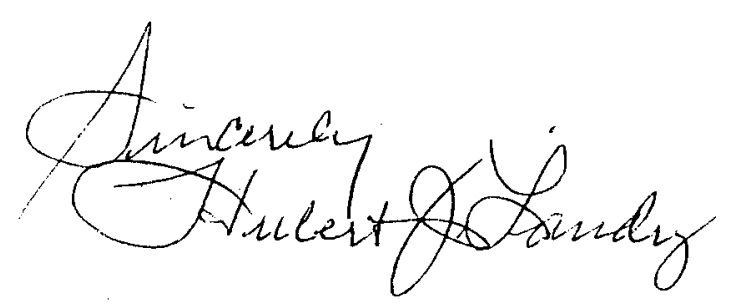

Pis. We were ot the above andrew of the time of the prover.

$-109-$ 
mes. Woris 2 . Snatic

7076 Lagrange

Loke Chark, $\operatorname{La}_{20605}$

Localed whow 10 block sosth of inchuse Ieniveisy

The trenow cancet me of go antside it see of by home (large Brict) hal suddenly sotalud so dugs as At crack -

$-110-$ 


\section{APPENDIX B}

Modified Mercalli Intensity Scale of 1931 (Abridged and rewritten)

I. Not felt.

II. Felt by persons at rest, on upper floors, or favorably placed.

III. Felt indoors. Hanging objects swing. Vibration like passing of light trucks. Duration estimated. May not be recognized as an earthquake.

IV. Hanging objects swing. Vibration like passing of heavy trucks; or sensation of a jolt like a heavy ball striking the walls. Standing motor cars rock. Windows, dishes, doors rattle. Glasses clink. Crockery clashes. In the upper range of IV wooden walls and frame creak.

$V$. Felt outdoors; direction estimated. Sleepers wakened. Liquids disturbed, some spilled. Small unstable objects displaced or upset. Doors swing, close, open. Shutters, pictures move. Pendulum clocks stop, start, change rate.

VI. Felt by all. Many frightened and run outdoors. Persons walk unsteadily. Windows, dishes, glassware broken. Knickknacks, books, etc., off shelves. Pictures off walls. Furniture moved or overturned. Weak plaster and masonry D cracked. Small bells ring (church, school). Trees, bushes shaken (visibly, or heard to rustle-CFR).

VII. Difficult to stand. Noticed by drivers of motor cars. Hanging objects quiver. Furniture broken. Damage to masonry D, including cracks. Weak chimneys broken at roof line. Fall of plaster, loose bricks, stones, tiles, cornices (also unbraced parapets and architectural ornaments-CFR). Some cracks in masonry $\mathrm{C}$. Waves on ponds; water turbid with mud. Small slides and caving in along sand or gravel banks. Large bells ring. Concrete irrigation ditches damaged.

VIII. Steering of motor cars affected. Damage to masonry C; partial collapse. Some damage to masonry $B$; none to masonry $A$. Fall of stucco and some masonry walls. Twisting, fall of chimneys, factory stacks, monuments, towers, elevated tanks. Frame houses moved on foundations if not bolted down; loose panel walls thrown out. Decayed piling broken off. Branches broken from trees. Changes in flow or temperature of springs and wells. Cracks in wet ground and on steep slopes.

$I X$. General panic. Masonry D destroyed; masonry $\mathrm{C}$ heavily damaged, sometimes with complete collapse; masonry B seriously damaged. (General damage to foundations-CFR.) Frame structures, if not bolted, shifted off foundations. Frames racked. Serious damage to reservoirs. Underground pipes broken. Conspicuous cracks in ground. In alluviated areas sand and mud cjected, carthquake fountains, sand craters.

$X$. Most masonry and frame structures destroyed with their foundations. Some well-built wooden structures and bridges destroyed. Serious damage to dams, dikes, embankments. Large landslides. Water thrown on banks of canals, rivers, lakes, etc. Sand and mud shifted horizontally on beaches and fiat land. Rails bent slightly.

$X I$. Rails bent greatly. Underground pipelines completely out of service.

$X$ II. Damage nearly total. Large rock masses displaced. Lincs of sight and level distorted. Objects thrown into the air. 
1

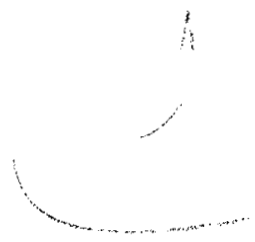

112 
U.S. Department of Energy

Nevada Operations office

Attn: Robert D. Clarke

(3 copies)

Engineering \& Energy Management Division

P.0. Box 14100-4100

Las Vegas, NV 89114

U.S. Department of Energy

Division of Geothermal Energy

(CE-324/SG-064 FORSTL)

(2 copies)

Washington, D.C. 20466

U.S. Department of Energy

Nevada Operations office

Attn: Dorothy Nowack

(2 copies)

for the NV Technical Library

P.0. Box 14100-4100

Las Vegas, NV 89114

U.S. Department of Energy

office of Scientific \& Technical Information

P.0. Box 62

Oak Ridge, TN 37831

(2 copies)

R.D. Roop

Oak Ridge National Laboratory

Building 2001

Oak Ridge, TN 37830

(1 copy) 


\begin{tabular}{|c|c|c|c|c|c|c|c|c|}
\hline Product Maare & Description & Foraula & Make-up Dosage & & Product Name & Description & Formula & Ma ke-up Dos age \\
\hline ALDACIDE- & $\begin{array}{l}\text { Para formal dehyde porder-- } \\
\text { toxic }\end{array}$ & $\left\{\mathrm{CH}_{2} \mathrm{O}\right) \times$ & $0.2-110 / b 01$ & & DRILTREATE & Phosphat lde liquid & -. & $0.5-4 \quad 1 \mathrm{~b} / \mathrm{bb}$ \\
\hline Al un Inum stearate & Ałun inum stearate ponder & $\left(\mathrm{CH}_{3}\left(\mathrm{CH}_{2}\right)_{16}(\mathrm{COO})_{3} \mathrm{AL}\right.$ & $\begin{array}{l}1 \text { qt/10 at diesel per } \\
\text { circulat lon }\end{array}$ & & EP MUDLUBE• & 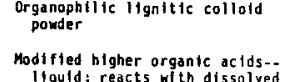 & -- & $2-2016 / 501$ \\
\hline AQUABEL & 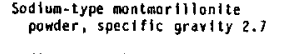 & $\cdot \cdot$ & $10-25 \quad 10 / b b l$ & & & $\begin{array}{l}\text { Ilyuld directts with dis sol ved } \\
\text { calclum }\end{array}$ & -. & $2-6 \quad 1 b / b b 1$ \\
\hline BARAFOS• & Sodiun tetraphosphate ponder & $\mathrm{Na}_{6} \mathrm{P}_{4} \mathrm{O}_{13}$ & $0.1-0.2 \quad 16 / 601$ & 1 & FibERTEX⿻ & Processed tane fibers & -- & $3-40 \quad l b / \Delta b 1$ \\
\hline BAROCO"- & $\begin{array}{l}\text { Calclum-type montmoriflonite } \\
\text { pounder }\end{array}$ & -- & $10-4010 / 0 b 1$ & & flose* & $\begin{array}{l}\text { Shrededed asbestos suspending } \\
\text { dgente }\end{array}$ & -. & $2-6$ \&b/bbl \\
\hline BAROIDO & $\begin{array}{l}\text { Pondered natural barlum } \\
\text { sulfate }\end{array}$ & $\mathrm{BaSO}_{4}$ & $0.700 \mathrm{~b} b / \mathrm{bb}$ & & Galena & Lead sulfide pouder, toxic & Pbs & $2300 \mathrm{lb} / \mathrm{bD} 1$ for $32 \mathrm{lb} / \mathrm{gal}$ aud \\
\hline Aicarbonate of soda & Sodium bicarbonate pouder & $\mathrm{NaHCO}_{3}$ & $0.1-1.5 \& b / b b 1$ & & Graphite & Carbon pousder & c & $1-2 \mid 0 / b 01$ \\
\hline Coiclui carbonate & Pondered 1 tmestone & $\mathrm{CaCO}_{3}$ & $50-700 \mathrm{lb} / \mathrm{bb1}$ & & Gypsum & Calc clum sul fate--ponder & $\mathrm{CaSO}_{4} 2 \mathrm{H}_{2} \mathrm{O}$ & $2-610 / 6 b 1$ \\
\hline Calcium chloride & caicluan chtorlde pouder & $\mathrm{CaCl}_{2}$ & $10-350 \mathrm{lb} / \mathrm{bbl}$ & & INVERAULC & $\begin{array}{l}\text { Modified calcium solts of } \\
\text { higher organic actas--pouder }\end{array}$ & $-\cdot$ & $5-25 \quad 10 / b b 1$ \\
\hline $\begin{array}{l}\text { CAN GEL"- } \\
\text { CARBOHOXO }\end{array}$ & $\begin{array}{l}\text { Bentonite } \\
\text { tignitic huaric actid poonder }\end{array}$ & $\begin{array}{l}-\cdot \\
\cdots\end{array}$ & $\begin{array}{l}10-25 \mathrm{lb} / 6 \mathrm{bl} \\
0.5-35 \mathrm{lb} / \mathrm{bb},\end{array}$ & & Ironite sponge & Synthetic tron oxide & $\mathrm{Fe}_{3} \mathrm{O}_{4}$ & 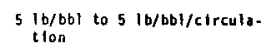 \\
\hline Caustic soda & $\begin{array}{l}\text { Sodtum hydroxtde flake. } \\
\text { toxic---strong ba se }\end{array}$ & $\mathrm{HaOH}$ & $0.1-31 b / b b 1$ & & $\begin{array}{l}\text { K-LIG- } \\
\text { LIme }\end{array}$ & $\begin{array}{l}\text { Potassium Iignite } \\
\text { Calcium hydroxide poodder }\end{array}$ & $\overline{\mathrm{Ca}(\mathrm{OH})_{2}}$ & $\begin{array}{l}3-3010 / 0 b 1 \\
0.5-810 / 061\end{array}$ \\
\hline CC-160 & 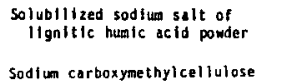 & .. & $0.5-6 \mathrm{lb/bb1} \xi^{\prime}$ & $\frac{1}{9}$ & $\begin{array}{l}\text { MICATEK⿻ } \\
\text { MUD GEL- }\end{array}$ & $\begin{array}{l}\text { Mica flakes, fine or coarse } \\
\text { Bentonite }\end{array}$ & $\ddot{-}$ & $\begin{array}{l}2-15 \quad b / b b \mid \\
10-251 b / b b 1\end{array}$ \\
\hline CELLExos & 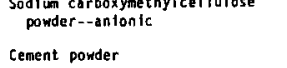 & $\begin{array}{l}-- \\
--\end{array}$ & $\begin{array}{l}0.1-1.5 \mid b / b b 1 \\
0.11 \mathrm{~b} / \mathrm{bb}-\text { - NeAT slurry }\end{array}$ & & $\begin{array}{l}\text { Potassium carbonate } \\
\text { Potessium chloride }\end{array}$ & $\begin{array}{l}\text { Inorganic powder-basic } \\
\text { Inarganic pouder }\end{array}$ & $\begin{array}{l}\mathrm{K}_{2} \mathrm{CO}_{3} \\
\mathrm{KCl}\end{array}$ & $0.5-3 \quad 10 / 601$ \\
\hline cement & $\begin{array}{l}\text { Cement pouder } \\
\text { Inorganic zinc salt for }\end{array}$ & $-\cdot$ & 0.1 b/bbl - REAT Slurry & & $\begin{array}{l}\text { Potassium chloride } \\
\text { Potassium dichromate }\end{array}$ & Inorganic ponder $\ldots 0 x|d| z \mid n g$ & & $2-50 \quad \mathrm{lb} / 6 \mathrm{bl}$ \\
\hline $\cos T^{*}-45$ & $\begin{array}{l}\text { Inarganic } 2 \text { 2nc salt for } \\
\text { sulfifide scavenging }\end{array}$ & $2 \cap \mathrm{CO}_{3}$ & $1-516 / 606$ & & & toxic & $\mathrm{k}_{2} \mathrm{Cr}_{2} \mathrm{Or}$ & Yery low \\
\hline $\cos T^{-}-113$ & 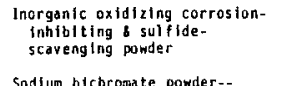 & $2 \mathrm{nCrO}_{4}$ & $500-2000 \mathrm{ppon}$ & & $\begin{array}{l}\text { Potassium hydroxide } \\
\text { Q-Broxino }\end{array}$ & $\begin{array}{l}\text { Inorganic pooder--strong base } \\
\text { Ferrochrome } 1 \text { ignosul fonate } \\
\text { powder }\end{array}$ & RoH & $0.25-316 / 661$ \\
\hline $\cos \Gamma^{-}-311$ & 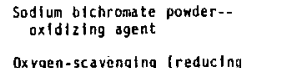 & $\mathrm{Ha}_{2} \mathrm{Cr}_{2} 07$ & 500-2000 prom in soluct ton & & $\begin{array}{l}\text { Salt } \\
\text { SAPP }\end{array}$ & $\begin{array}{l}\text { Sodium chloride, granular } \\
\text { Sodium acld pyrophosphate. }\end{array}$ & $\mathrm{HaCl}$ & $5.12516 / 667$ \\
\hline tOAT"-m & 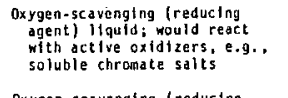 & $\left(\mathrm{NH}_{4}\right)_{2} \mathrm{SO}_{3}$ & $1 / 4$ to $1 \mathrm{gal} / / \mathrm{tr}$ & & SHENTOX: & $\begin{array}{l}\text { gratiular } \\
\text { Buffered } \\
\text { porder }\end{array}$ & $\mathrm{Ha}_{2} \mathrm{II}_{2} \mathrm{P}_{2} \mathrm{O}_{7}$ & $\begin{array}{l}0.1-0.210 / 001 \\
0.1-1.510 / 001\end{array}$ \\
\hline COAI"-вBa & 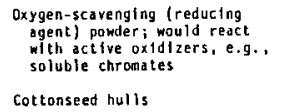 & $\begin{array}{l}\mathrm{Na}_{2} \mathrm{SO}_{3} \\
-.\end{array}$ & $\begin{array}{l}2.5 \text { to } 10 \mathrm{lb} / \mathrm{hr} \\
5-40 \mathrm{lb} / \mathrm{bbl}\end{array}$ & & $\begin{array}{l}\text { Soda ash } \\
\text { Sodiun enromate }\end{array}$ & $\begin{array}{l}\text { Sodium carbonate porder-- } \\
\text { basic } \\
\text { Sodium chromate pchder, } \\
\text { toxic- }\end{array}$ & $\mathrm{Na}_{2} \mathrm{CO}_{3}$ & $0.5-2 \quad 10 / 001$ \\
\hline $\begin{array}{l}\text { Cottonsed hulls } \\
\text { crpane }\end{array}$ & $\begin{array}{l}\text { Cottonseed hul 1s } \\
\text { sodtum pol yacrylate - ponder-- } \\
\text { ofionic }\end{array}$ & -- & $0.25-2 \quad 16 / b b 1$ & $\ldots$ & SURFLO- - H35 & $\begin{array}{l}\text { coxic--oxtd izer } \\
\text { Antontc phosphonate Itguid for } \\
\text { scale gid }\end{array}$ & $\mathrm{Na}_{2} \mathrm{CrO}_{4}$ & $0.5-2 \quad 16 / b b 7$ \\
\hline & Ol trmanon lus phosphate granules & $\left(\mathrm{NHI}_{4}\right)_{2 \mathrm{H}} \mathrm{PO}$ & $2-10 \quad 16 / 6 b 1$ & & TORQ-TR LT & $\begin{array}{l}\text { scale and corroston lantib- } \\
\text { tion; temperature stable }\end{array}$ & -- & $5-15$ ppa in water \\
\hline DOACIDED & $\begin{array}{l}\text { Irichiorophenate of sodiua-- } \\
\text { toxic ponder }\end{array}$ & .. & $0.2-0.316 / 6 b 1$ & 1 & & $\begin{array}{l}\text { Beended Hquud kriglycerides } \\
\text { and alcoho is }\end{array}$ & .. & $\begin{array}{l}16-610 / 6 b \mid \text { as lubricant } \\
30-90 \text { lb/bol for stuck pipe }\end{array}$ \\
\hline & & & & & & $\begin{array}{l}\text { Tetrassod unpyrophos phate } \\
\text { pamier }\end{array}$ & $\mathrm{Na}_{4} \mathrm{P}_{2} \mathrm{O}_{7}$ & $0.1-0.216 / b b 1$ \\
\hline & & & & & HALL-NUT" & Granular nut hulls & -- & $2-10 \mathrm{~J} / \mathrm{bb}$ \\
\hline - & & & 2.15 & & $W_{L}-100$ & $\begin{array}{l}\text { Sodum polyacrylate powder-- } \\
\text { anlonic }\end{array}$ & -- & $0.25-2 \quad 1 \mathrm{~d} / b b 1$ \\
\hline & & & 1 & & ZEOGELO & At tapulgit te &.- & $5-2016 / 601$ \\
\hline
\end{tabular}

TABLE 3. Common drilling fluid additives (modified from NL Baroid, 1983). 


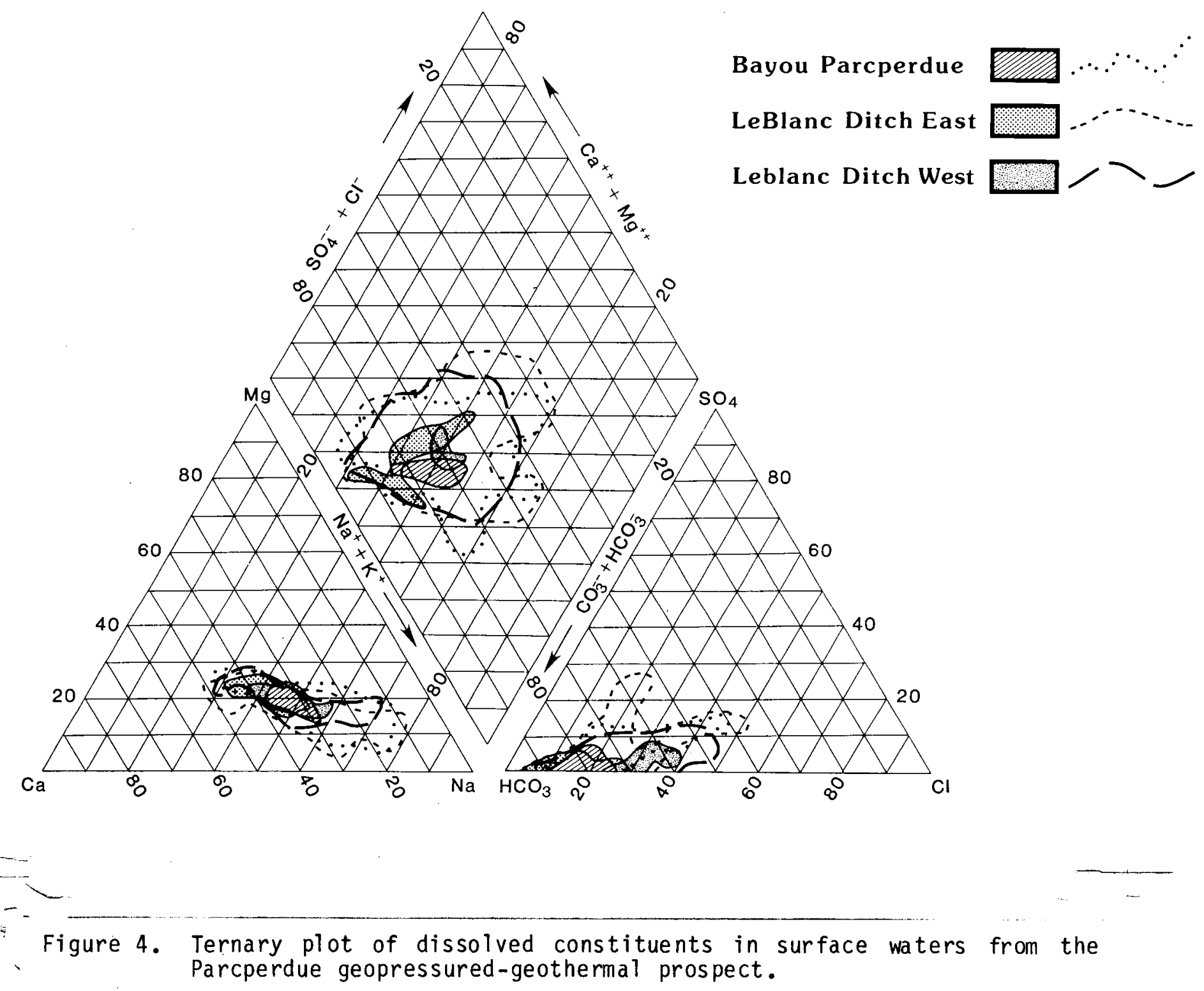




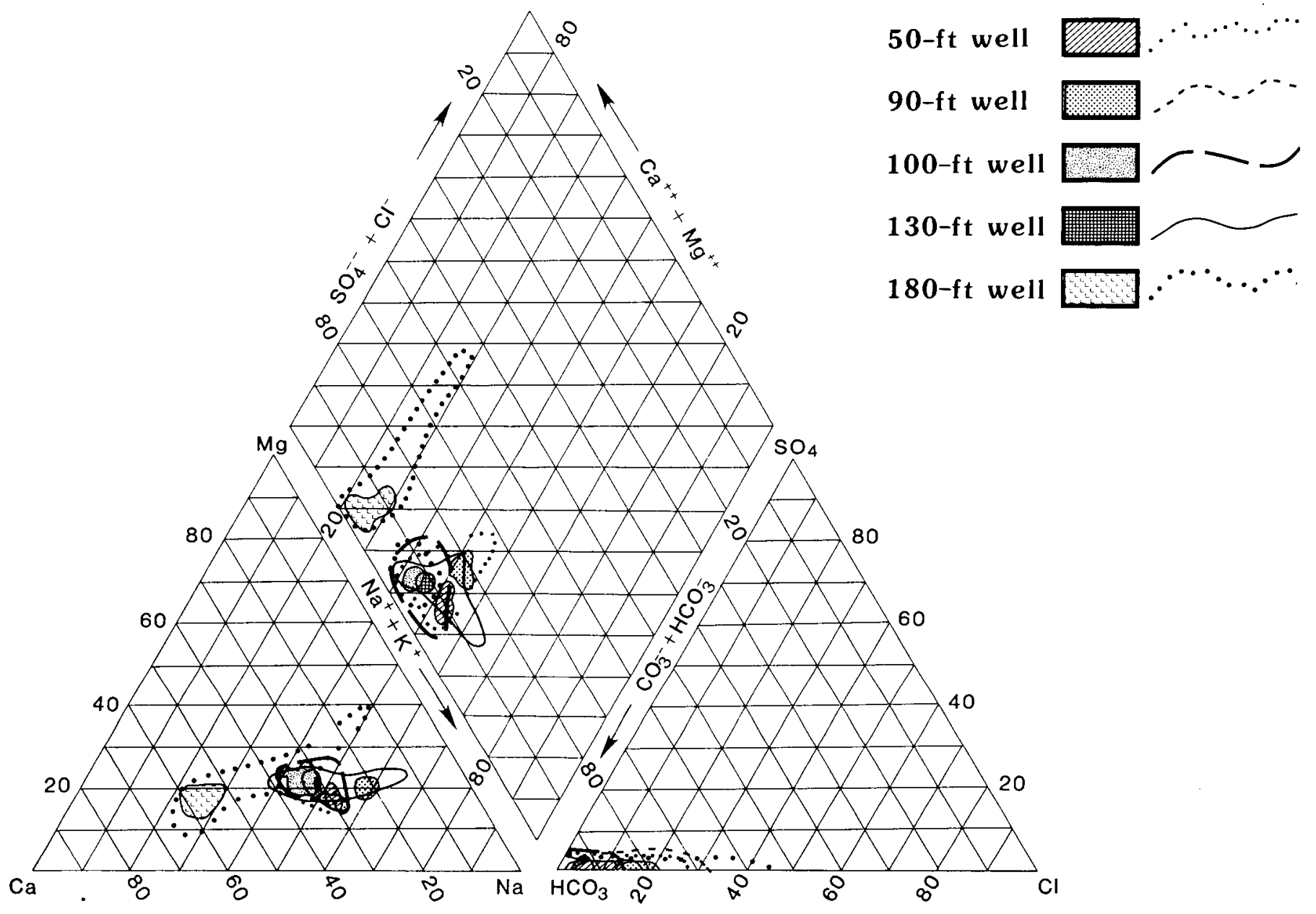

$\sqrt{-1}$

Figure 5. Ternary plot of dissolved constituents in ground waters from the Parcperdue geopressured-geothermal prospect. 


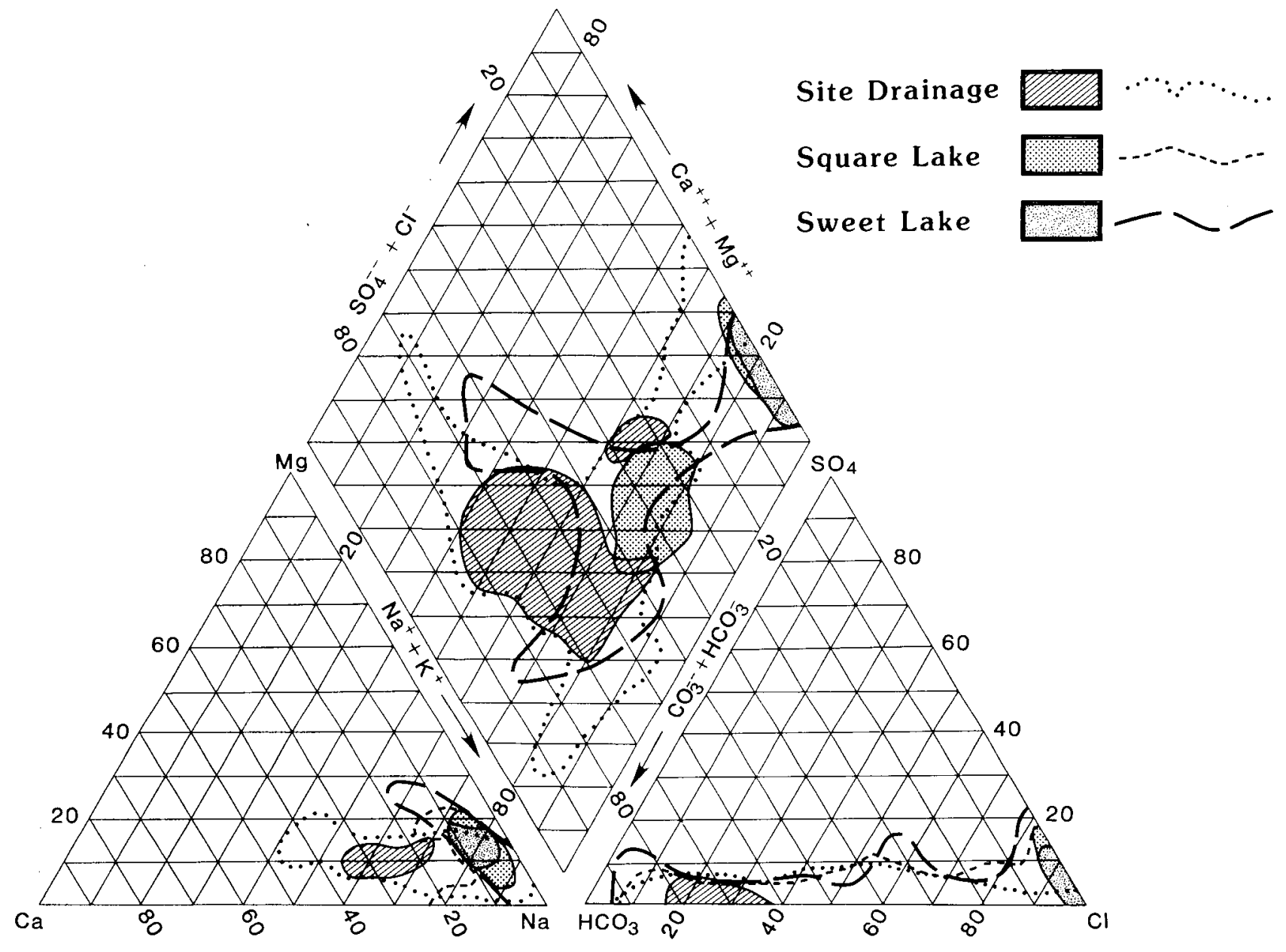
Figure 6. Ternary plot of dissolved constituents in surface waters from the
Sweet Lake geopressured-geothermal prospect. 


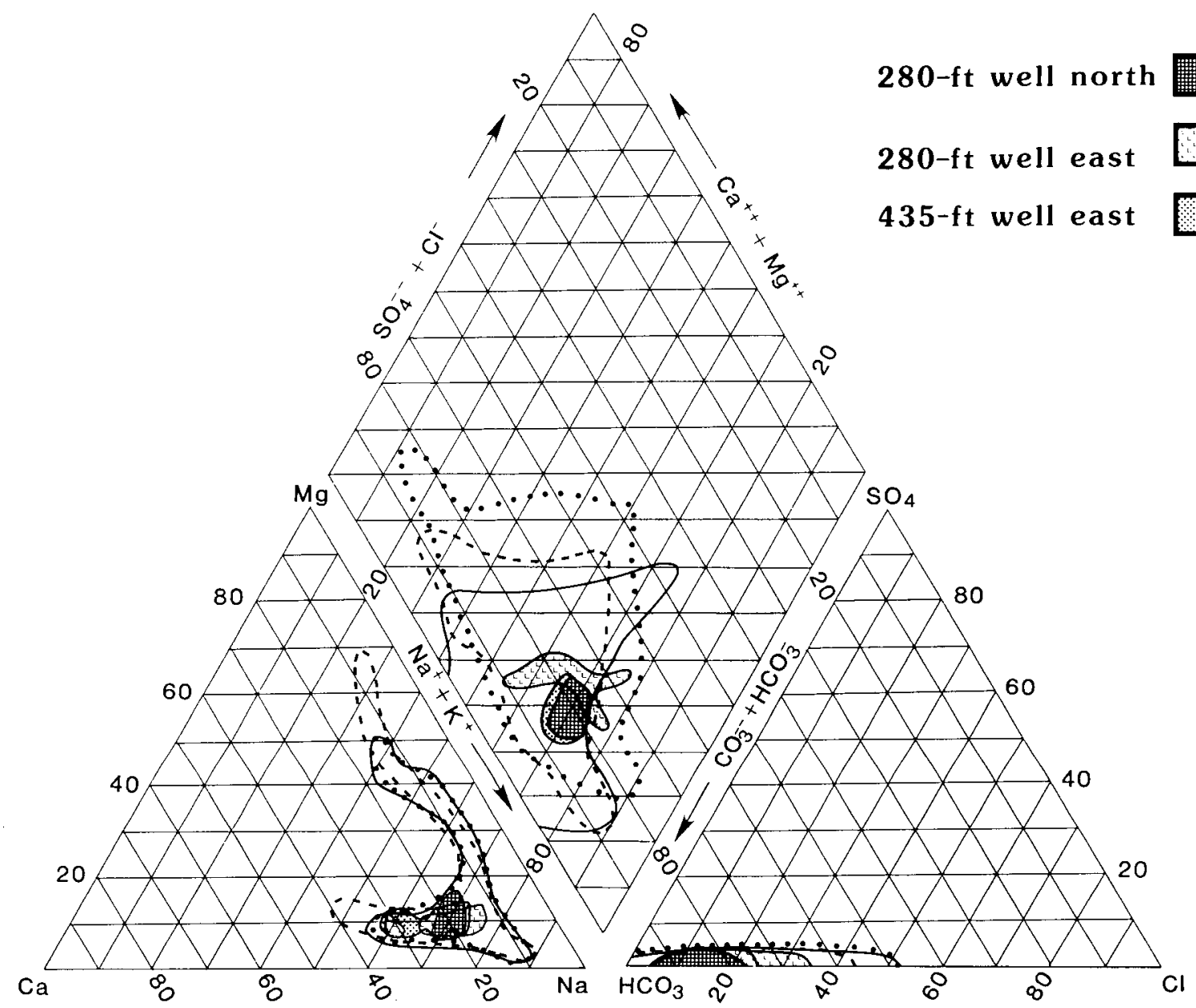

Figure 7. Ternary plot of dissolved constituents in ground waters from the Sweet Lake geopressured-geothermal prospect. 


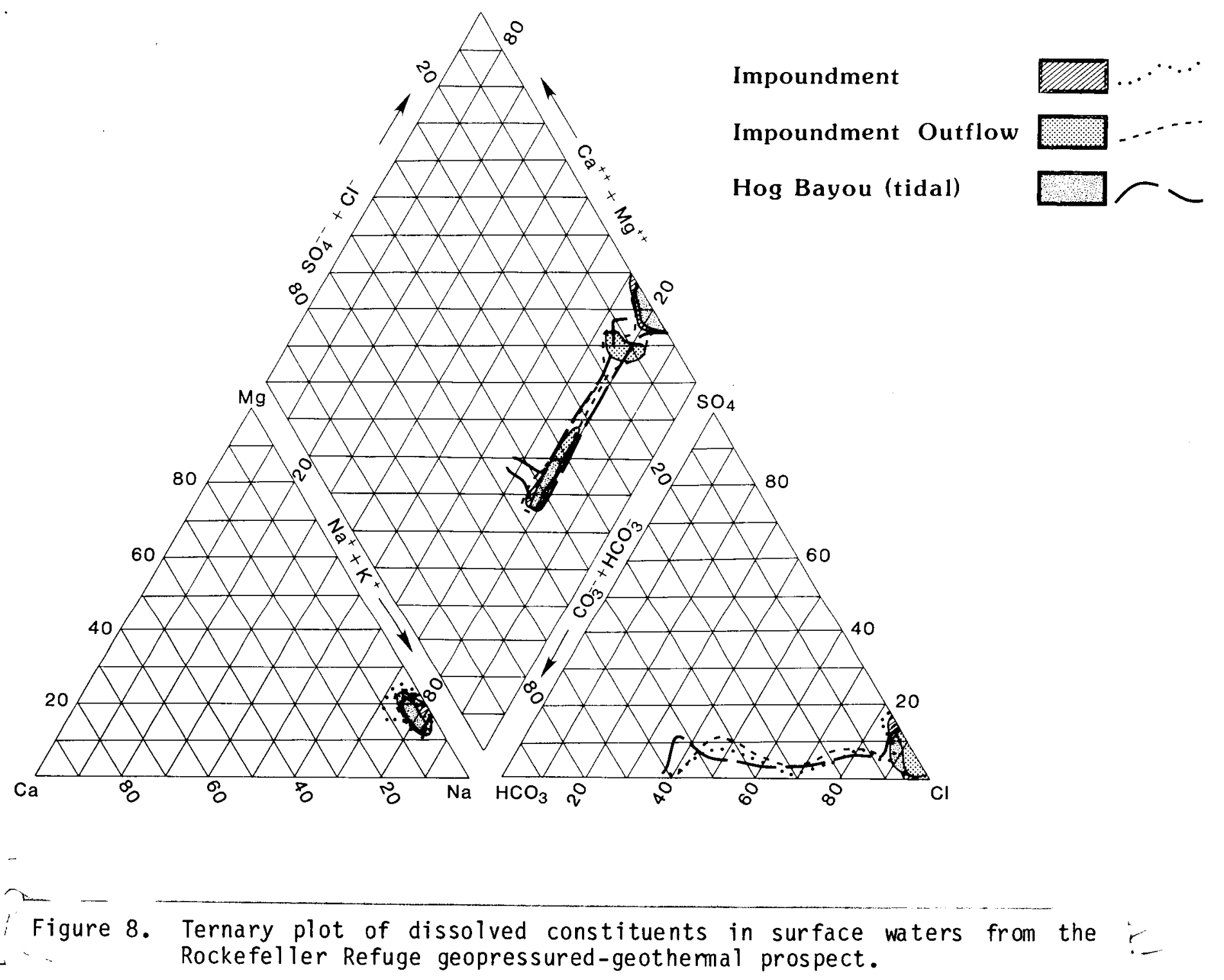




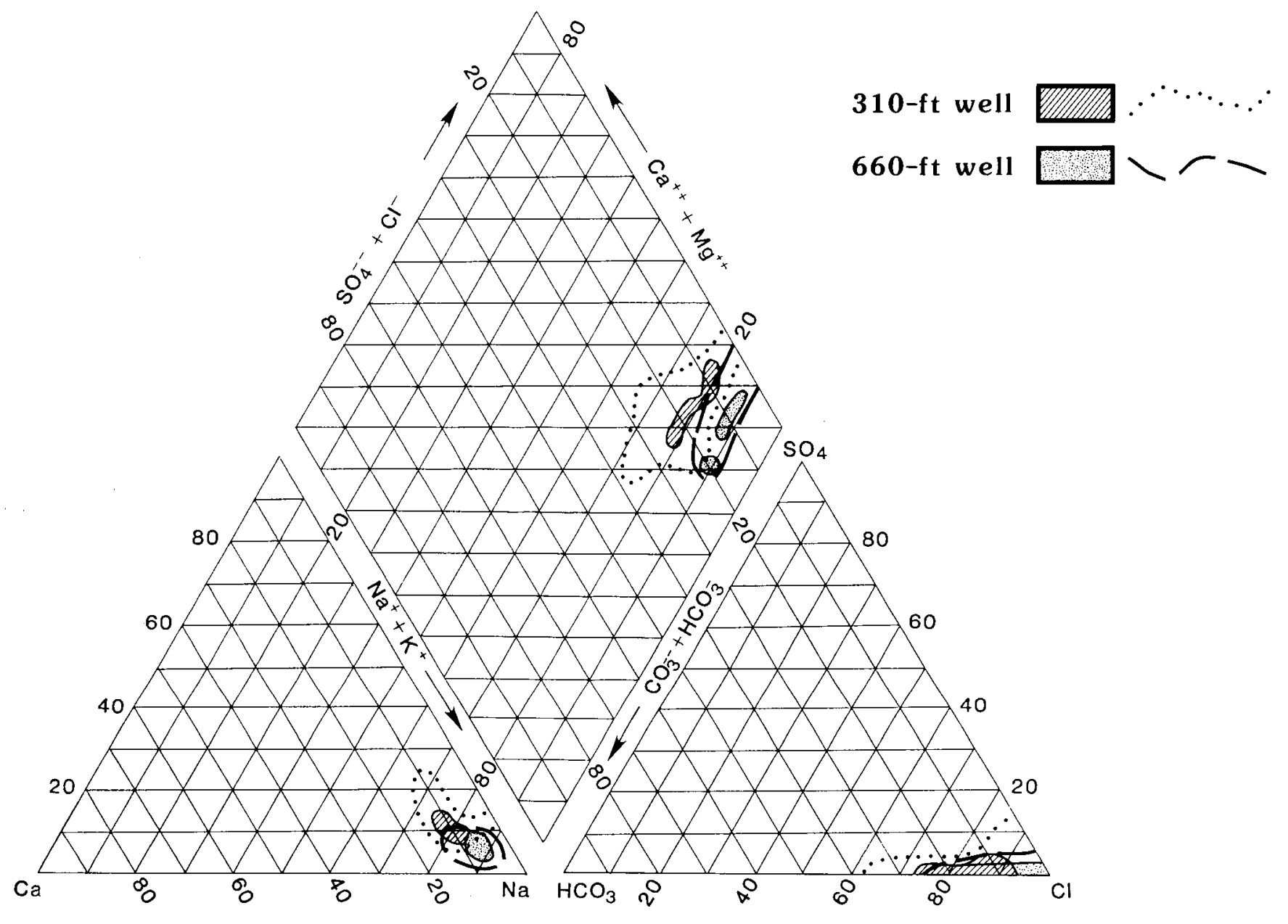

Figure 9. Ternary plot of dissolved constituents in ground waters from the Rockefeller Refuge geopressured-geothemal prospect. 


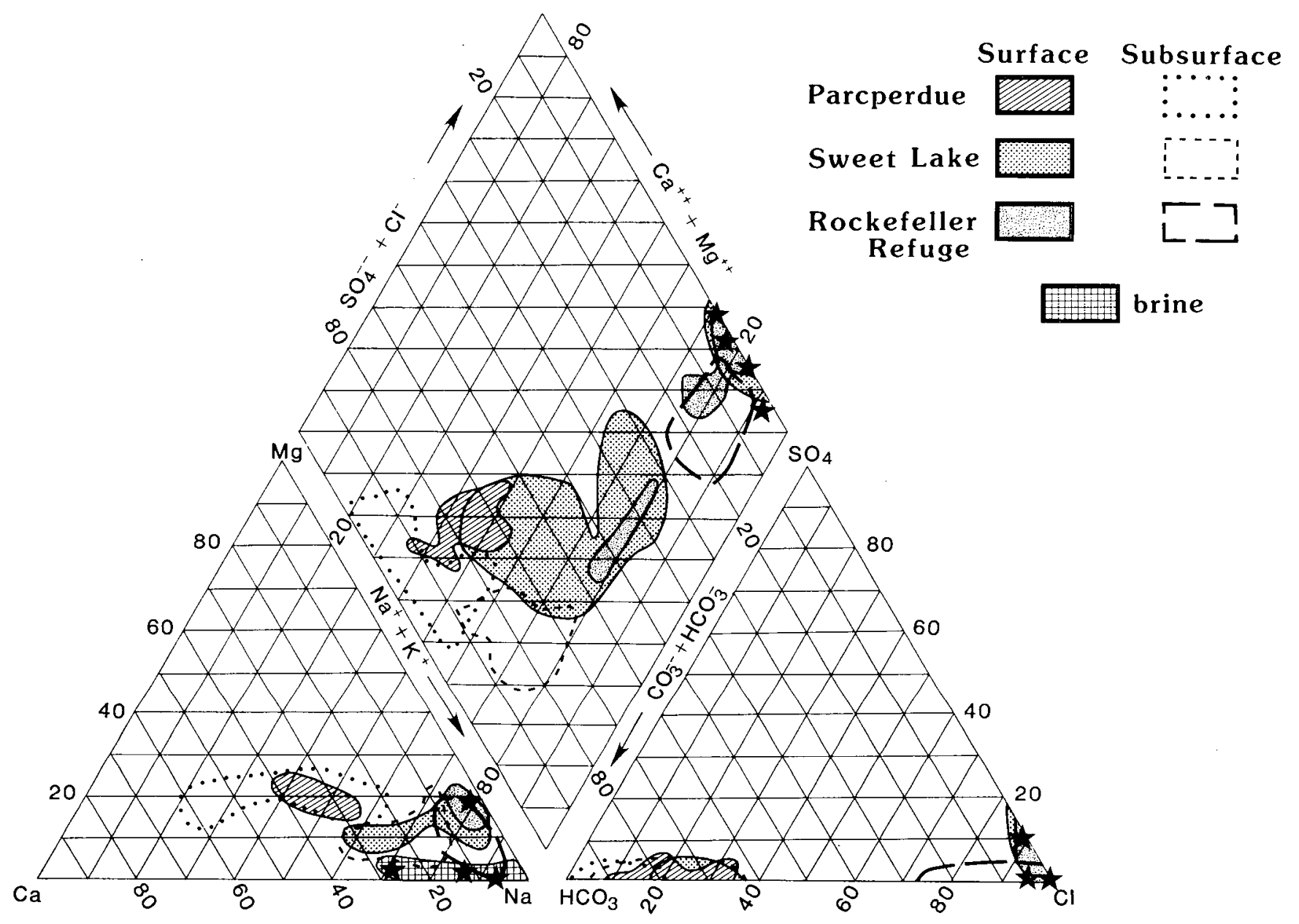

Figure 10. Ternary plot of dissolved constituents in natural waters from design geopressured-geothermal prospects in southwestern Louisiana. Stars represent the composition of seawater and subsurface brines. 


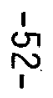
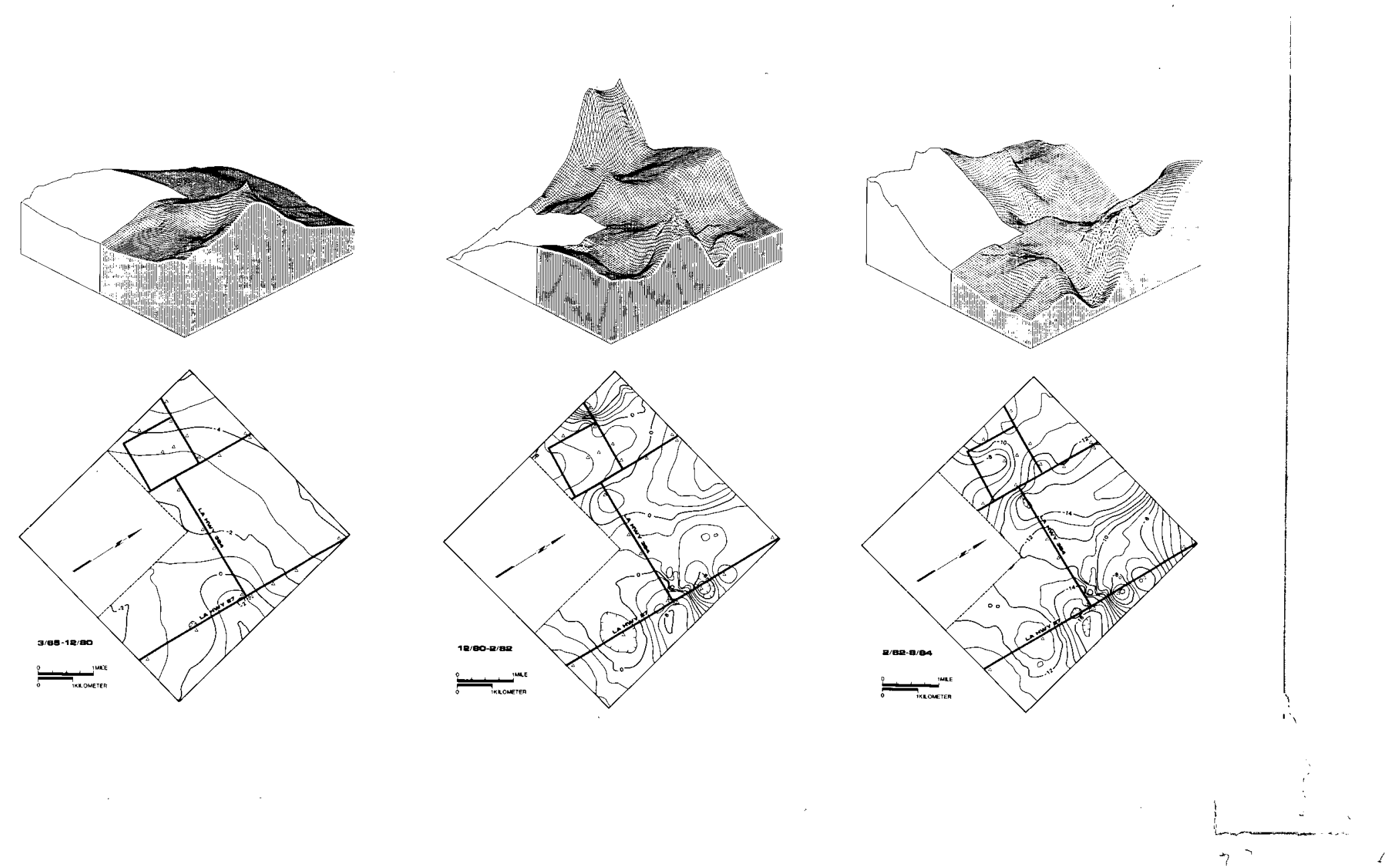

Figure 1. Elevation changes (in millimeters) for benchmarks around the Sweet Lake geopressured-geothemal prospect. Surface II Graphics (Sampson, 1978). 


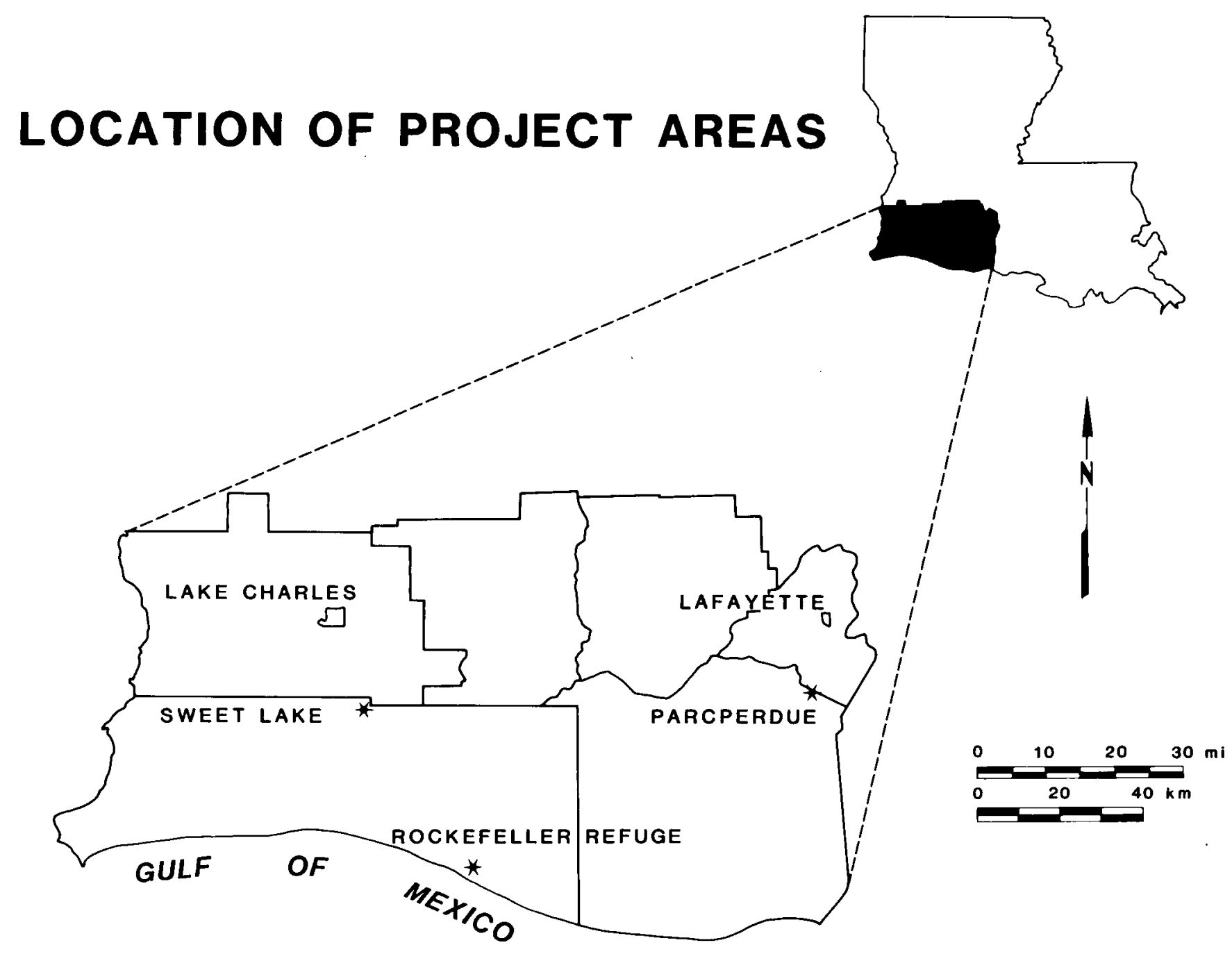

Figure 1. Location of geopressured-geothermal prospects, southwestern Louisiana. 

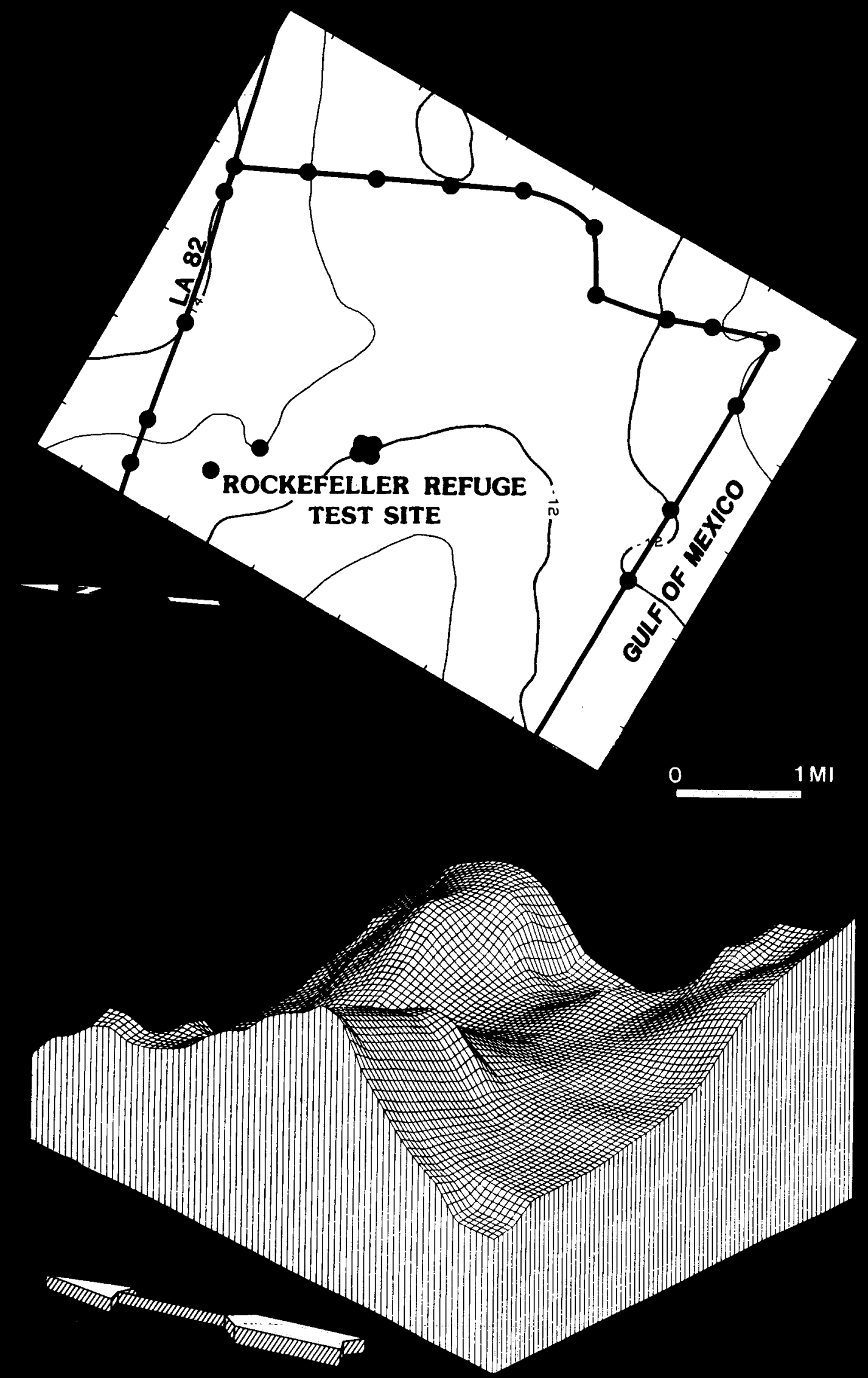

Figure 2. Subsidence rates (mm/yr) for benchmarks around the Rockefeller Refuge geopressured-geothermal prospect, October 1981 to July 1984. 


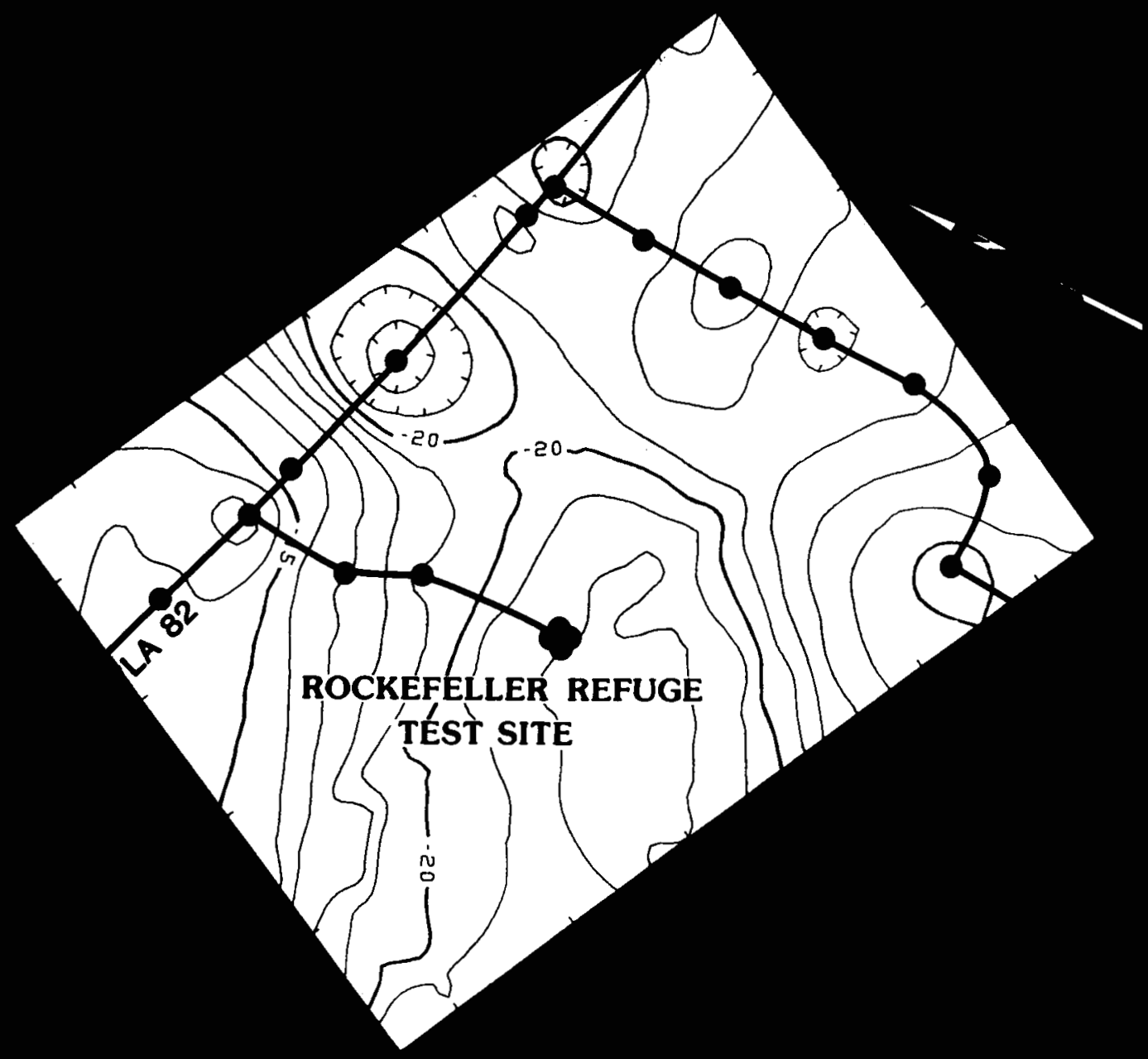

0

$1 \mathrm{MI}$

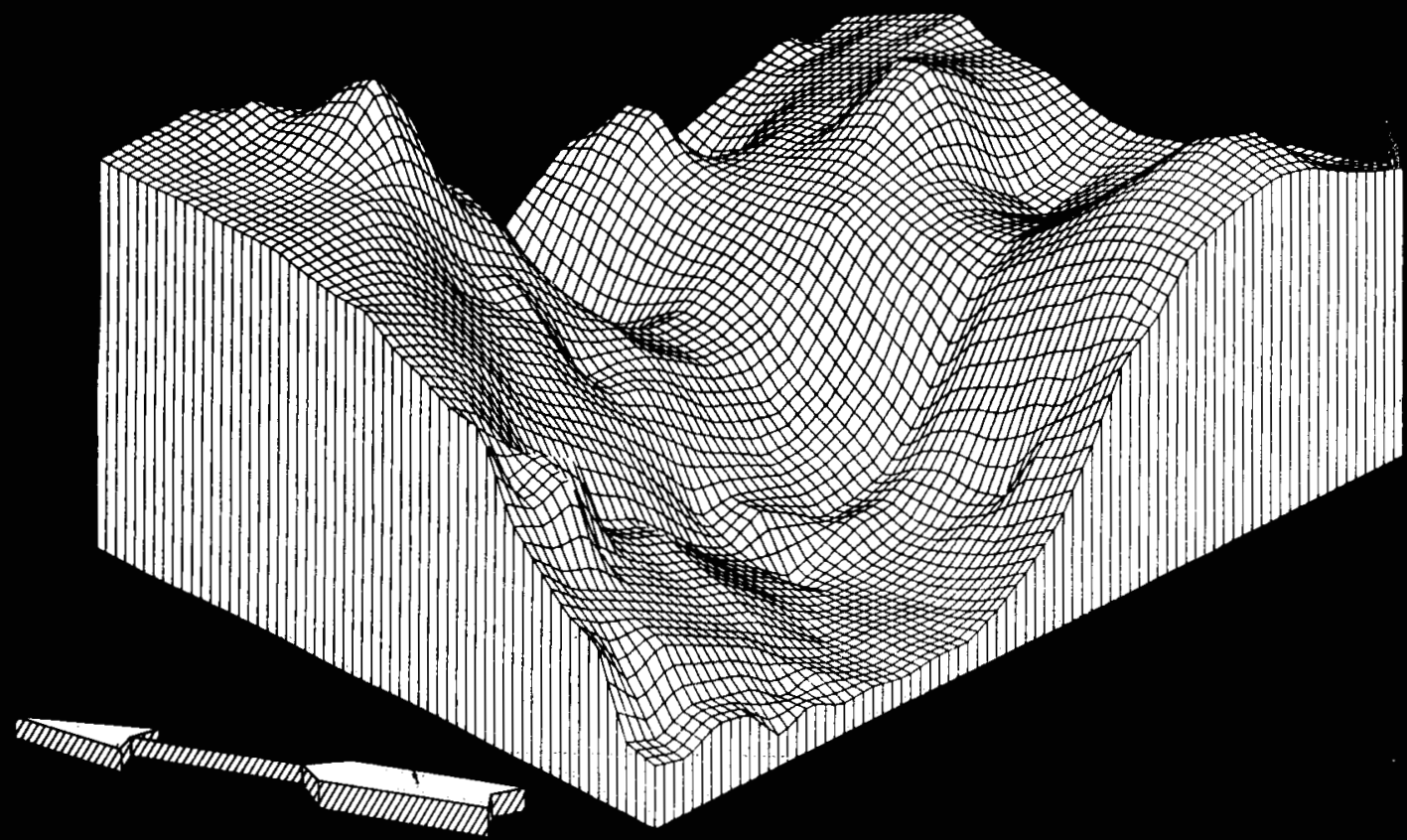

Figure 3. Subsidence rates (mm/yr) for benchmarks around the Rockefeller Refuge geopressured-geothermal prospect, October 1981 to June 1982. 


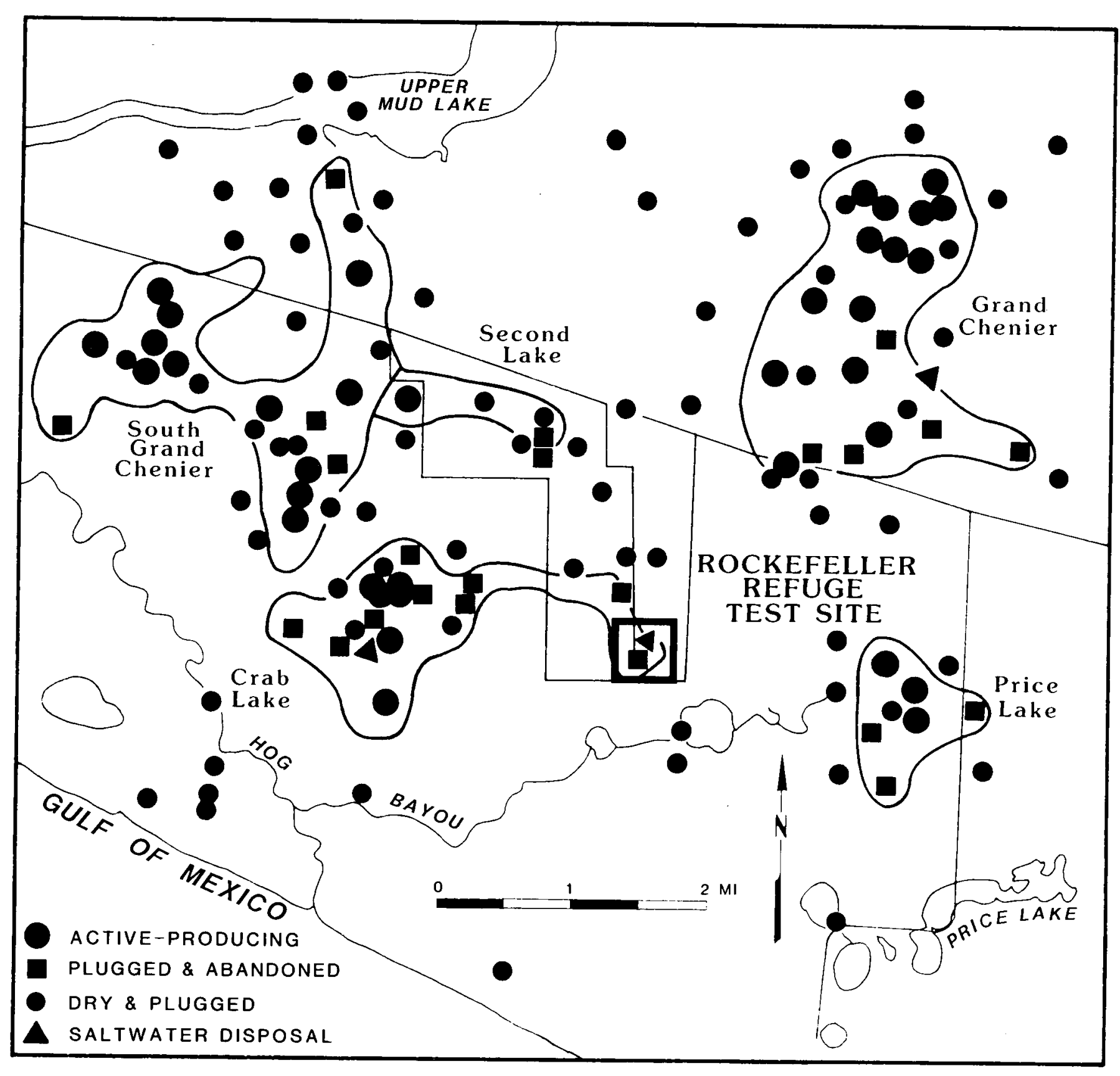

Figure 4. Historical oil and gas development at Rockefeller Refuge. 


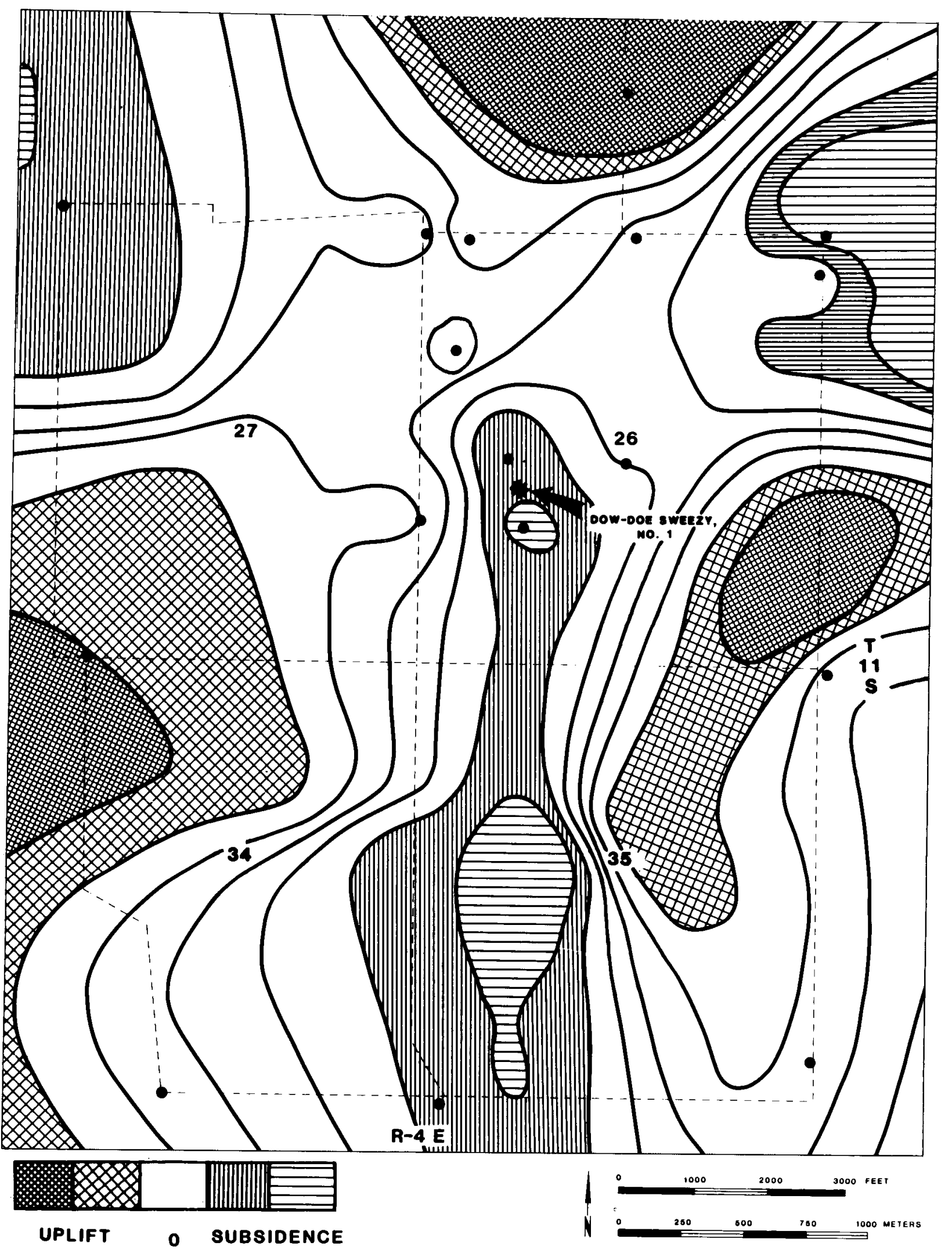

Figure 5. Second-order residual surface for elevation changes (mm/yr) for benchmarks around the Parcperdue geopressured-geothermal prospect, 1980-81. 


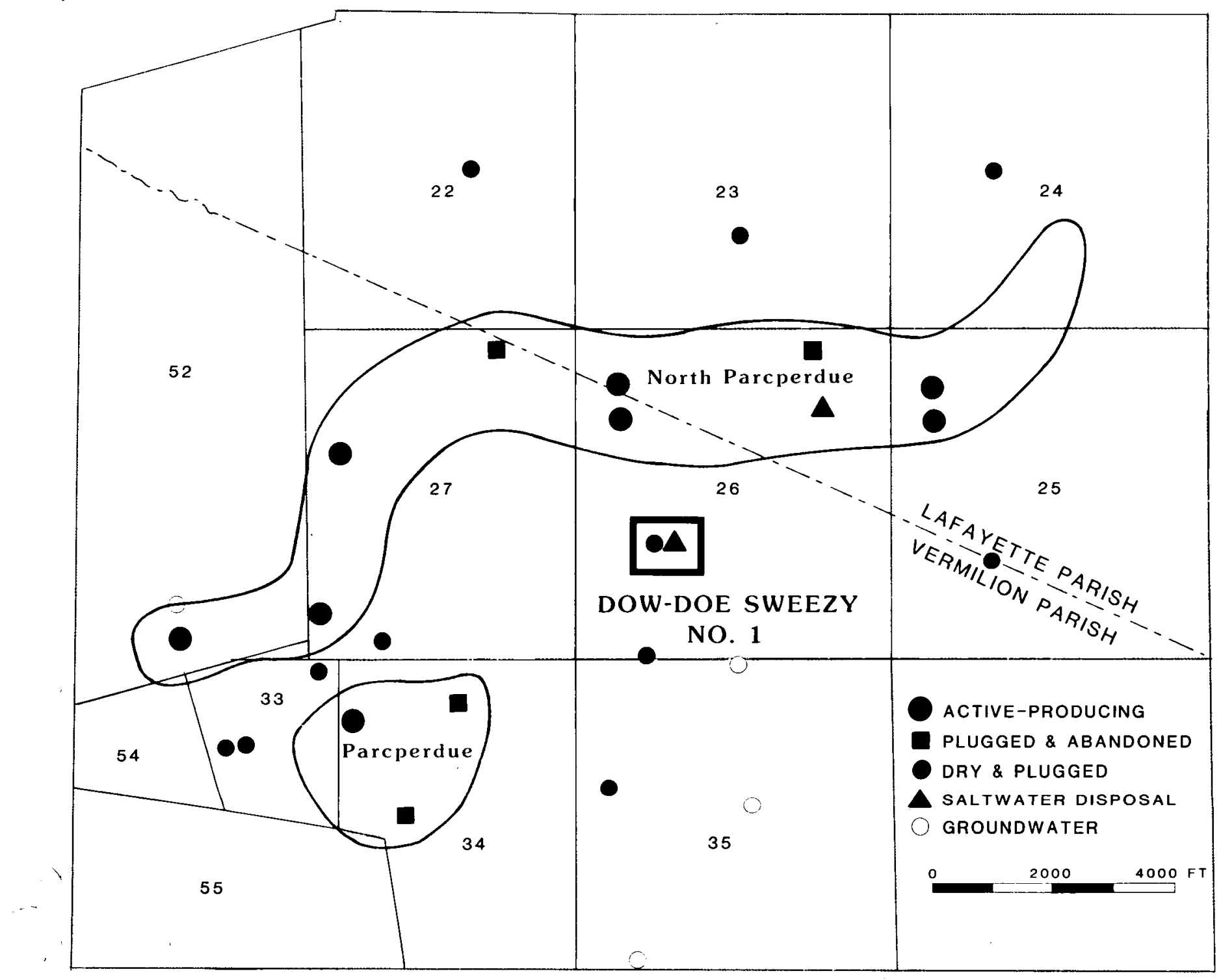

Figure 6. Historical 0il, gas, and groundwater development at Parcperdue. 


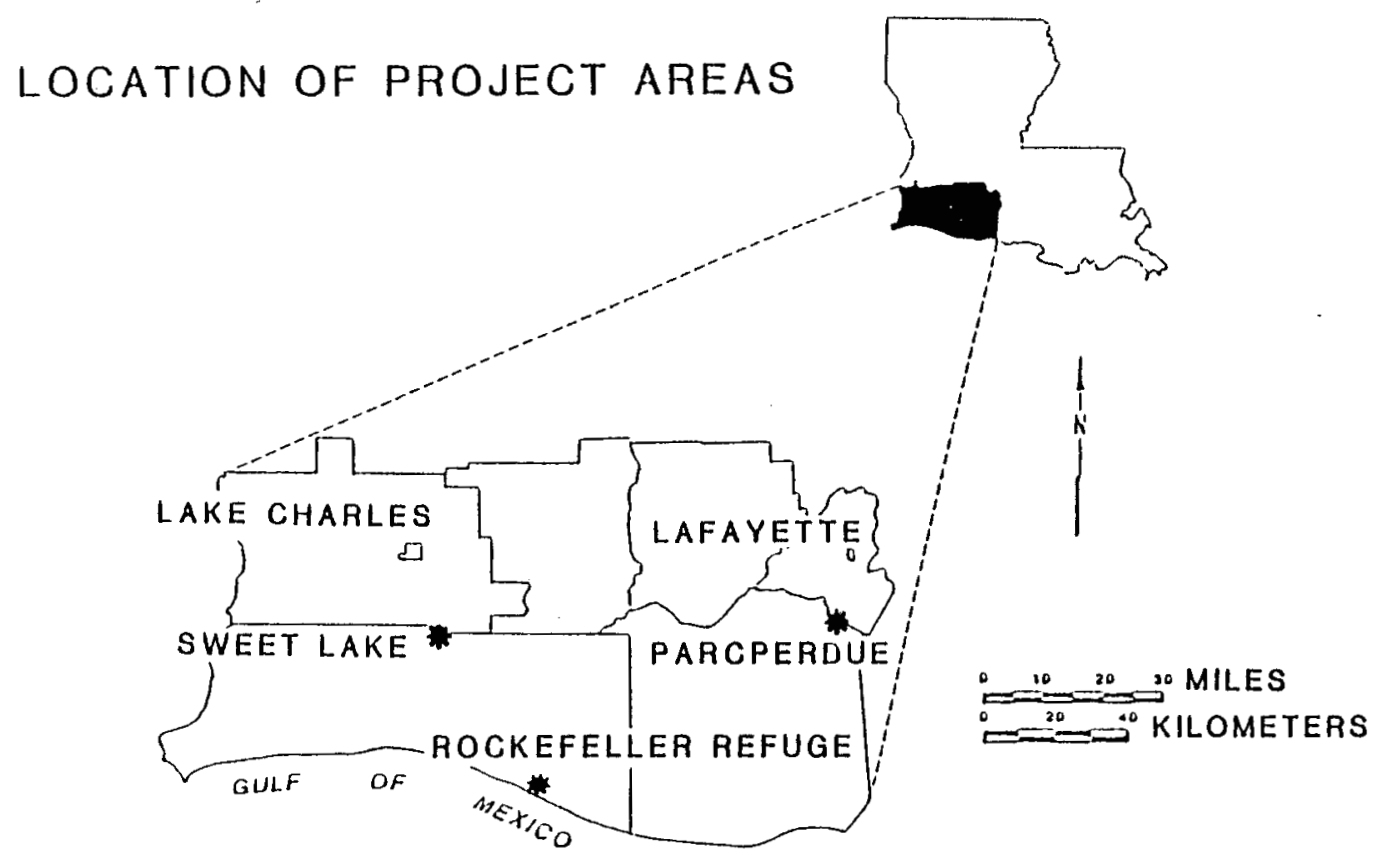

FIGURE 1. Locations of the DOE Sweet Lake, Parcperdue, and Rockefeller Refuge geopressured-geothermal prospects in Louisiana. 


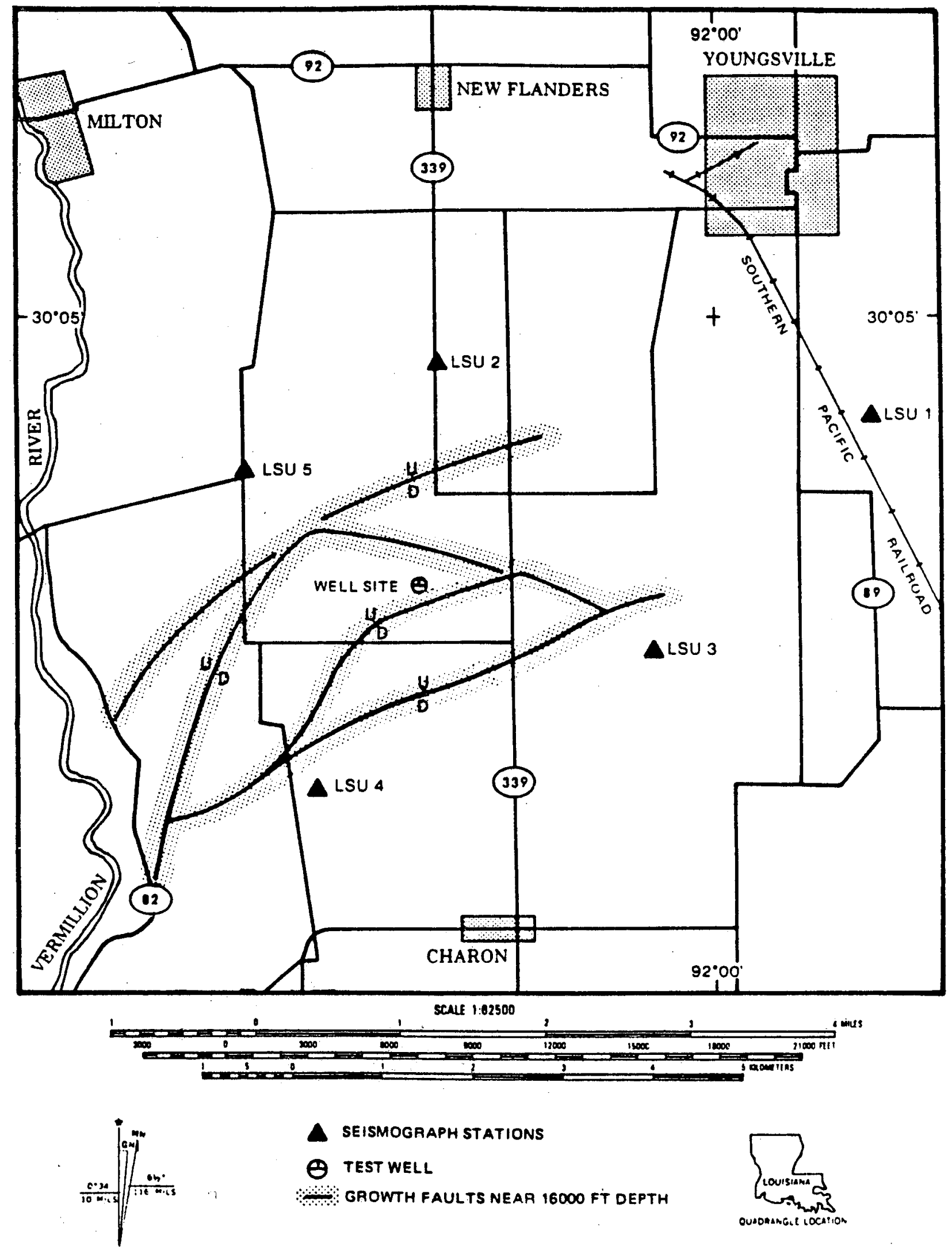

FIGURE 2. Parcperdue seismic array. 


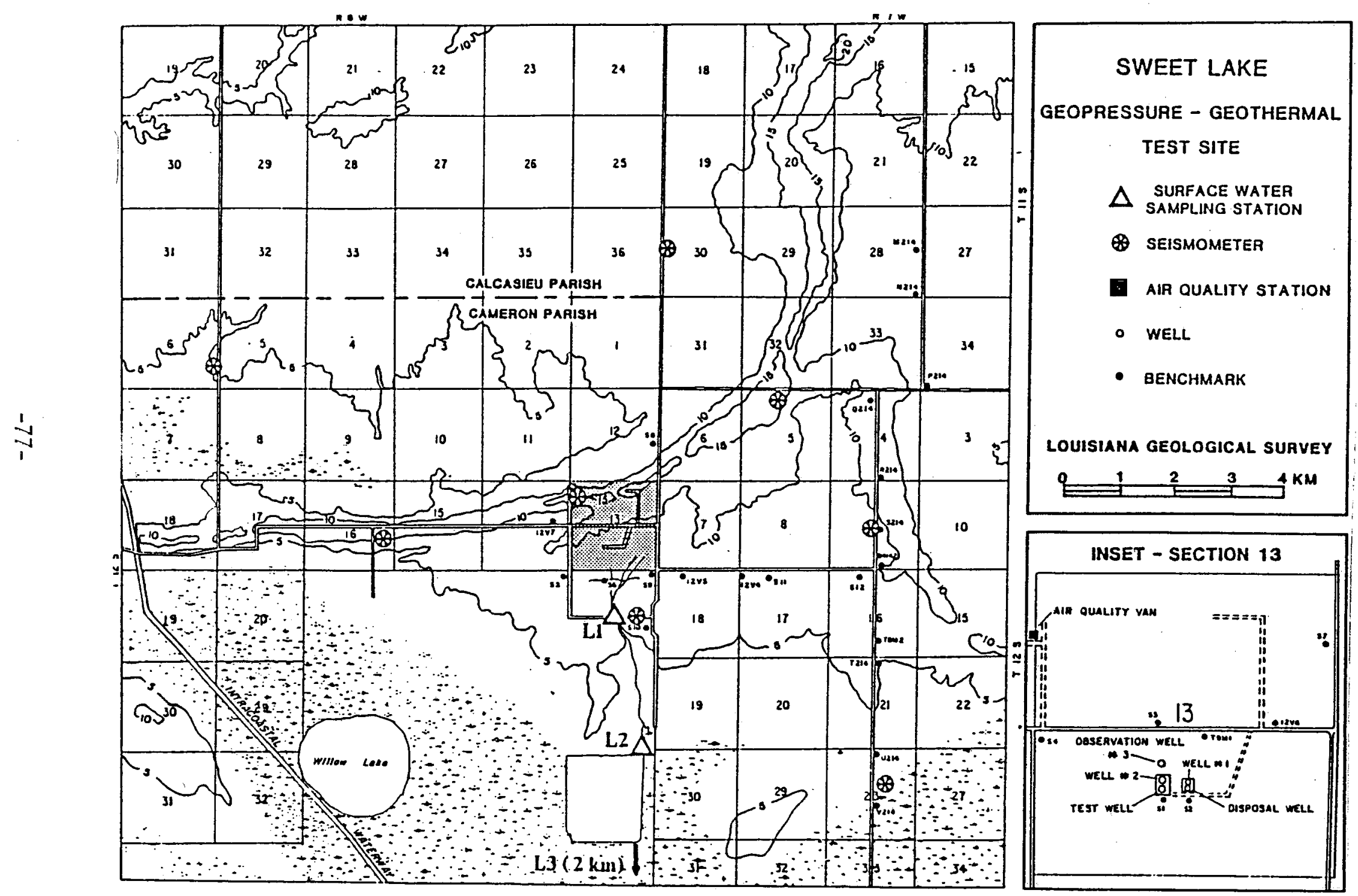

FIGURE 3. Sweet Lake seismic array. 


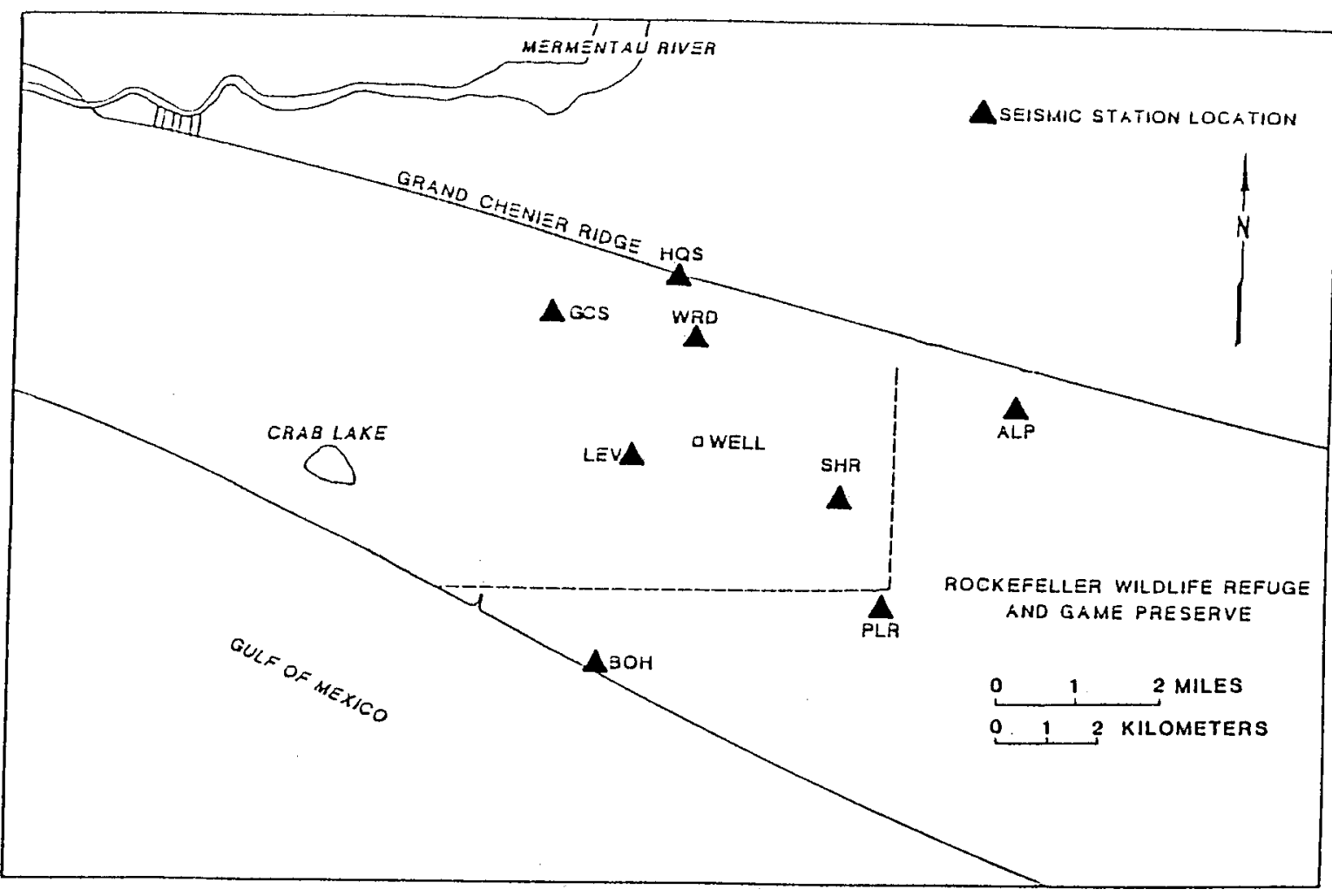

FIGURE 4. Rockefeller Refuge seismic array. 


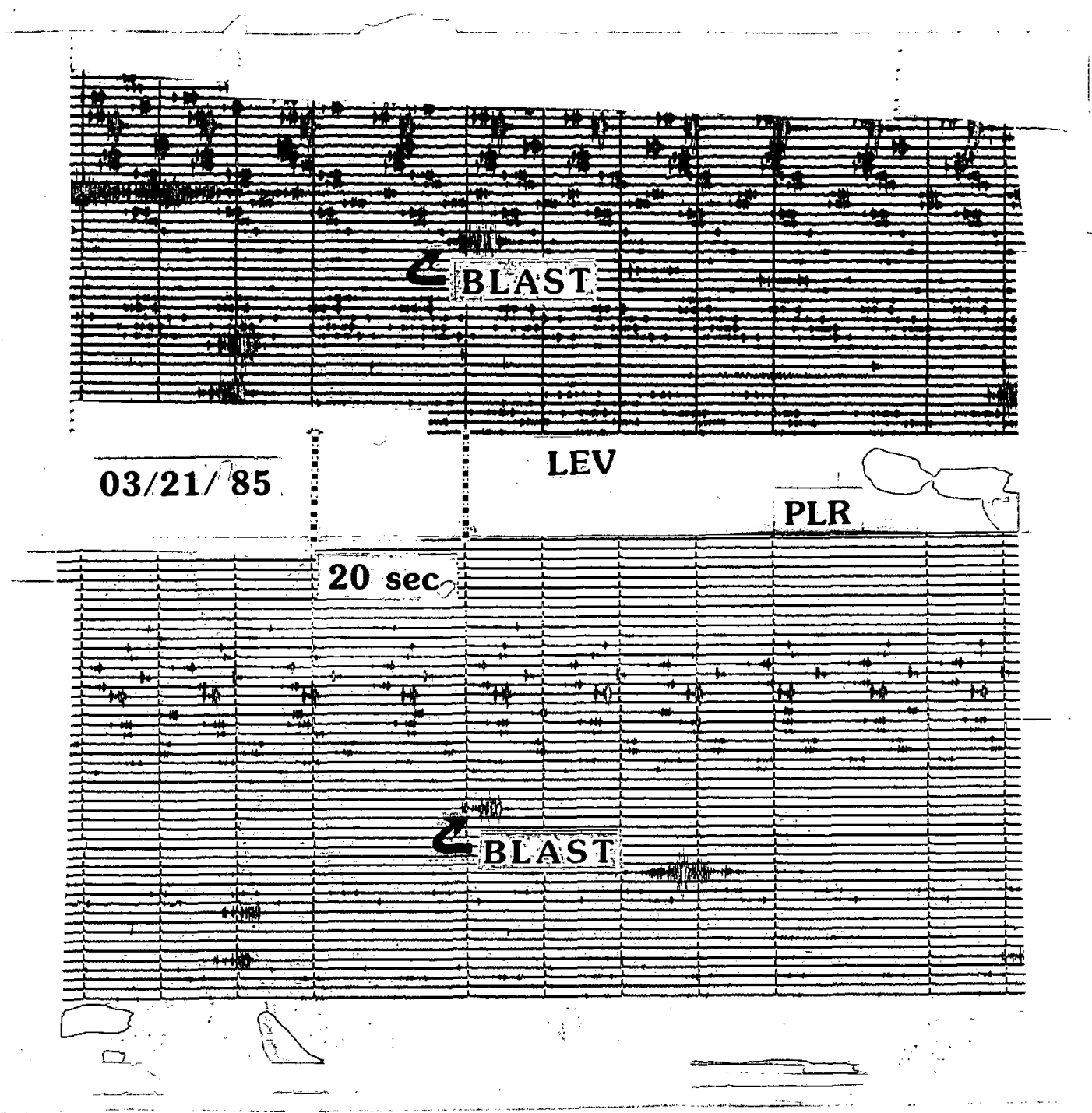

FIGURE 5. Regular type signals from Rockefeller Refuge network with geophysical exploration blast. 

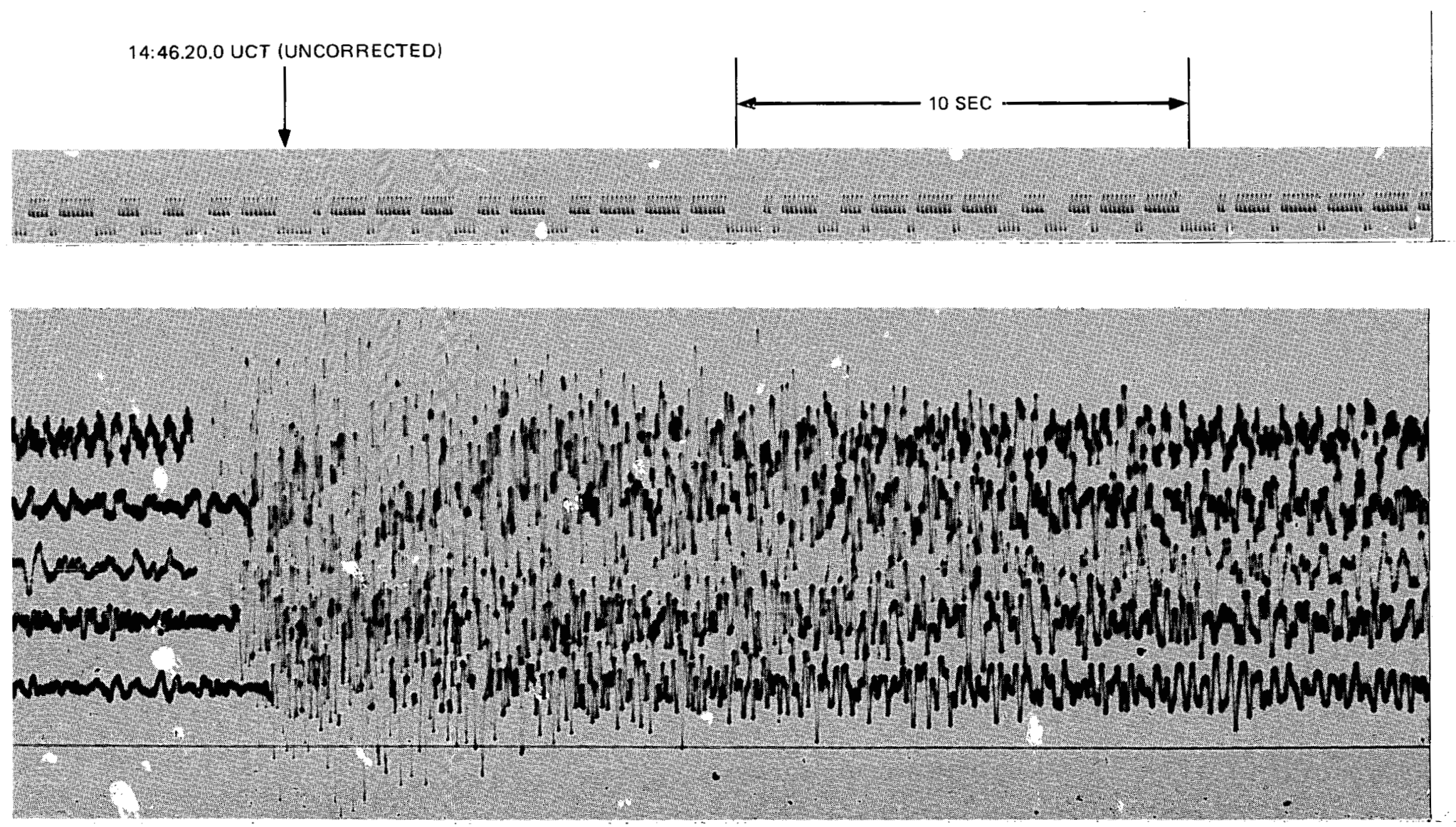

FIGURE 6. Type I event, Parcperdue network. 


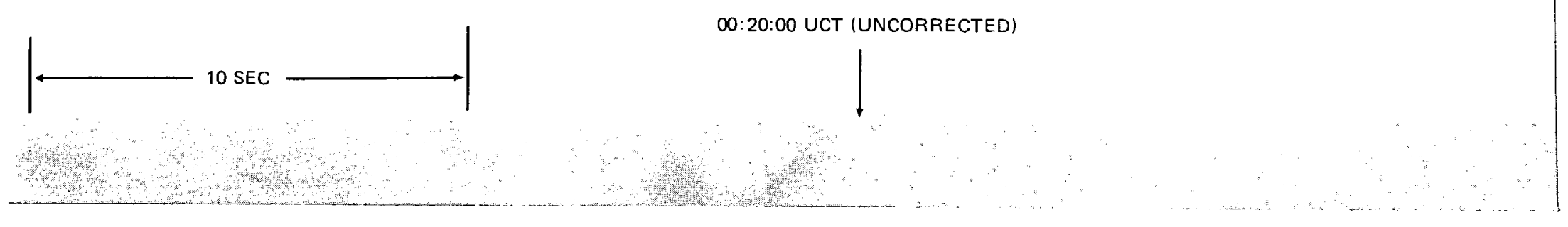

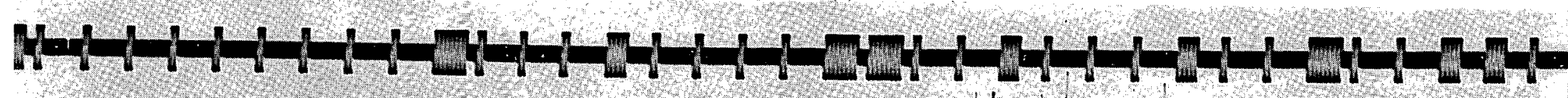

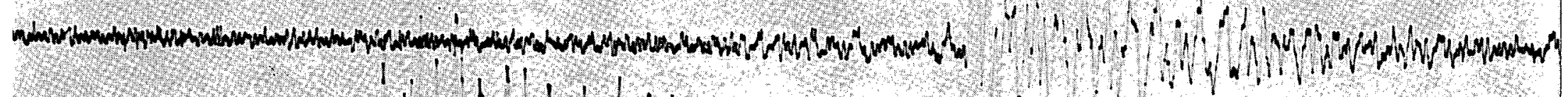

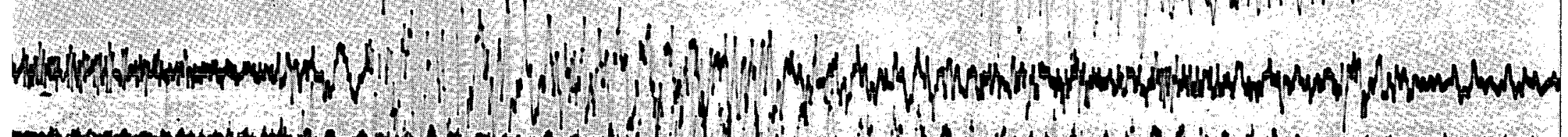

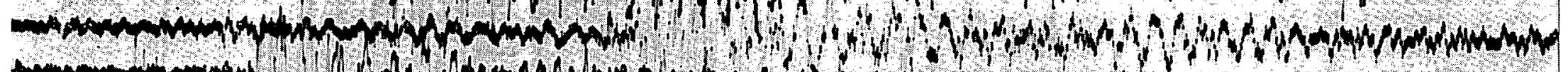

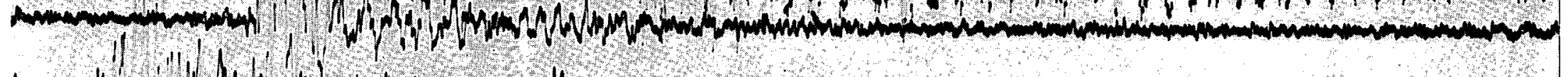

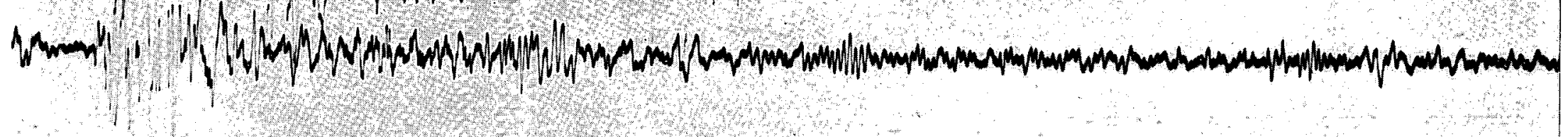

FIGURE 7. Type II event, Parcperdue network. 


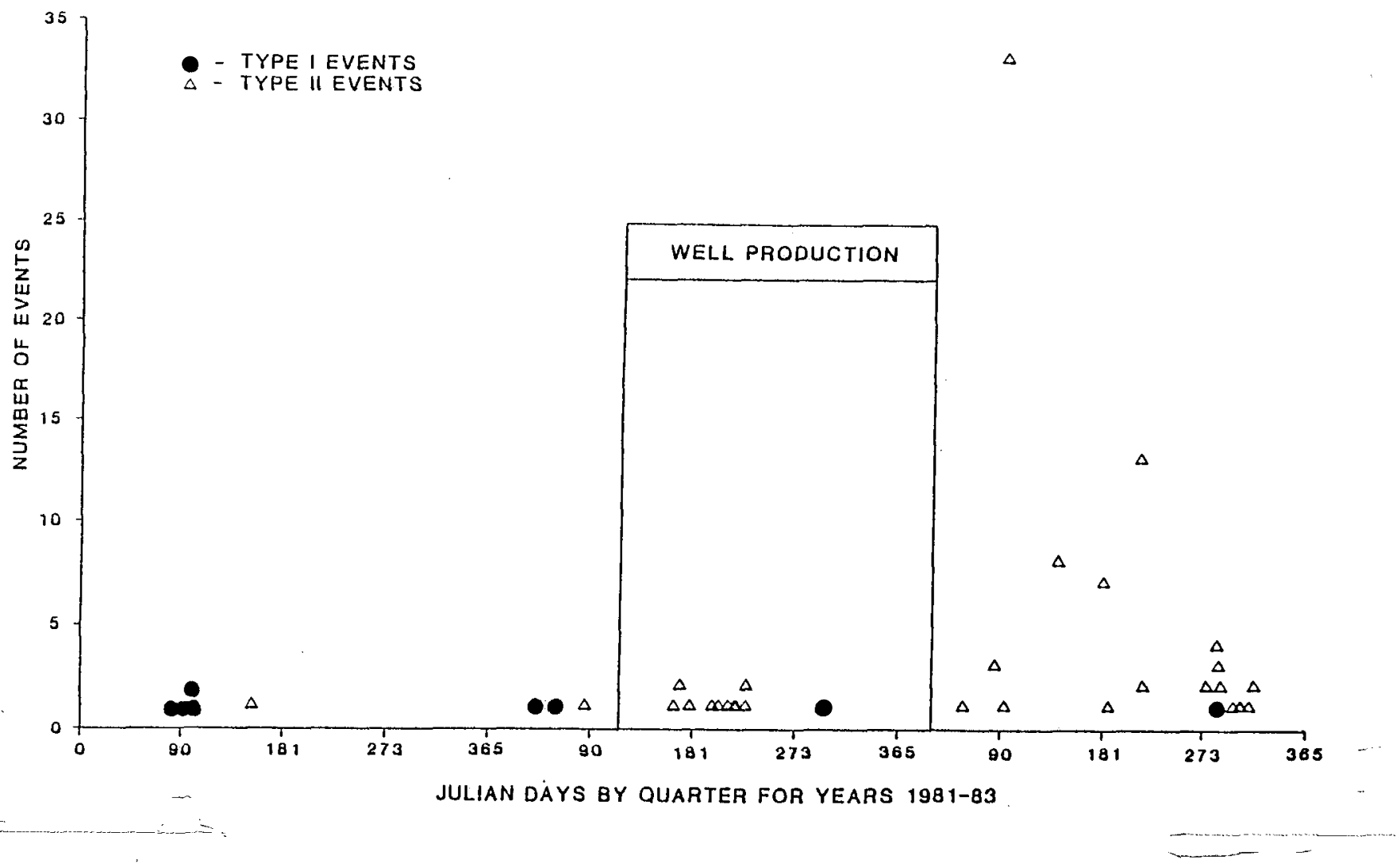

FIGURE 8. Distribution of seismic events and well production at Parcperdue. 


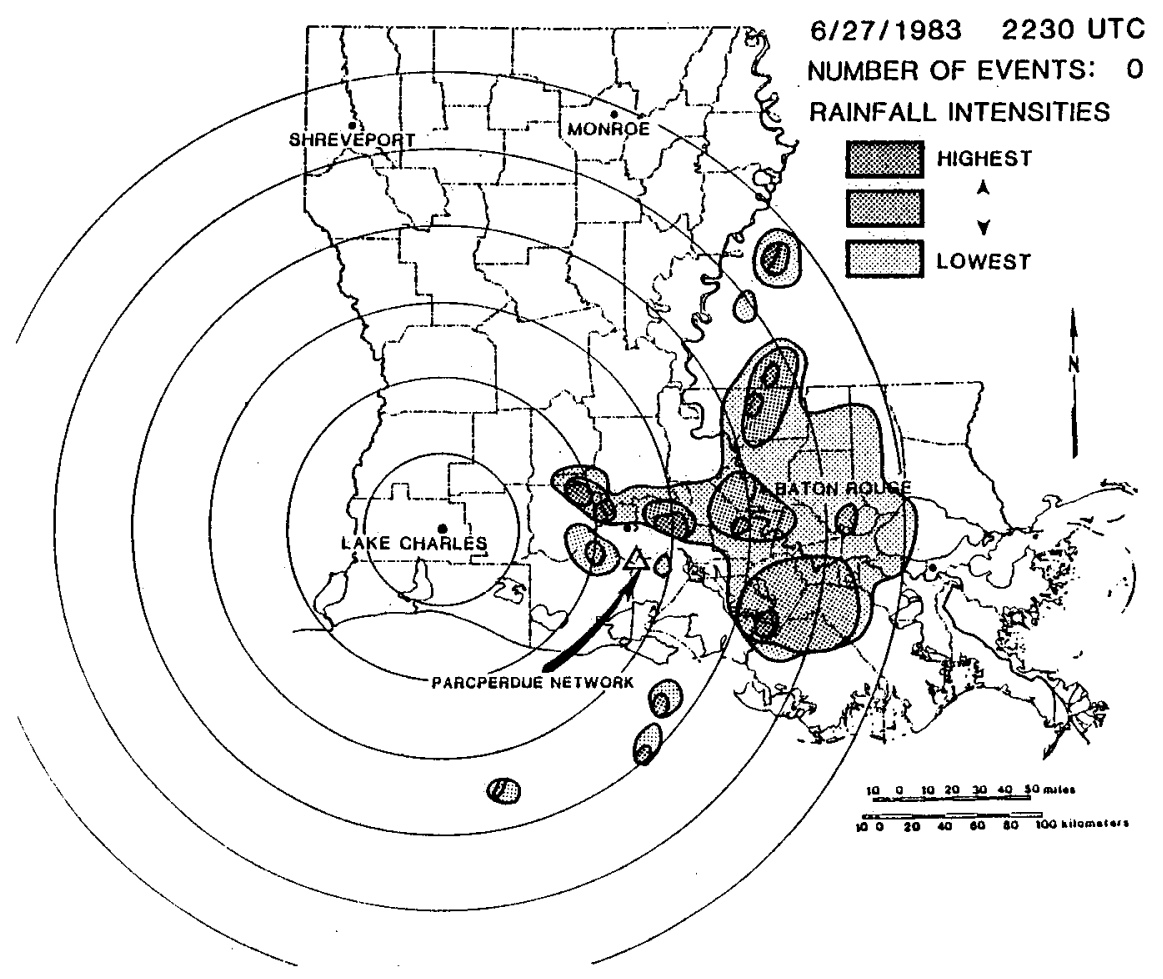

FIGURE 9. Lake Charles radar summary chart, 27 June 1983, 2230 UTC.

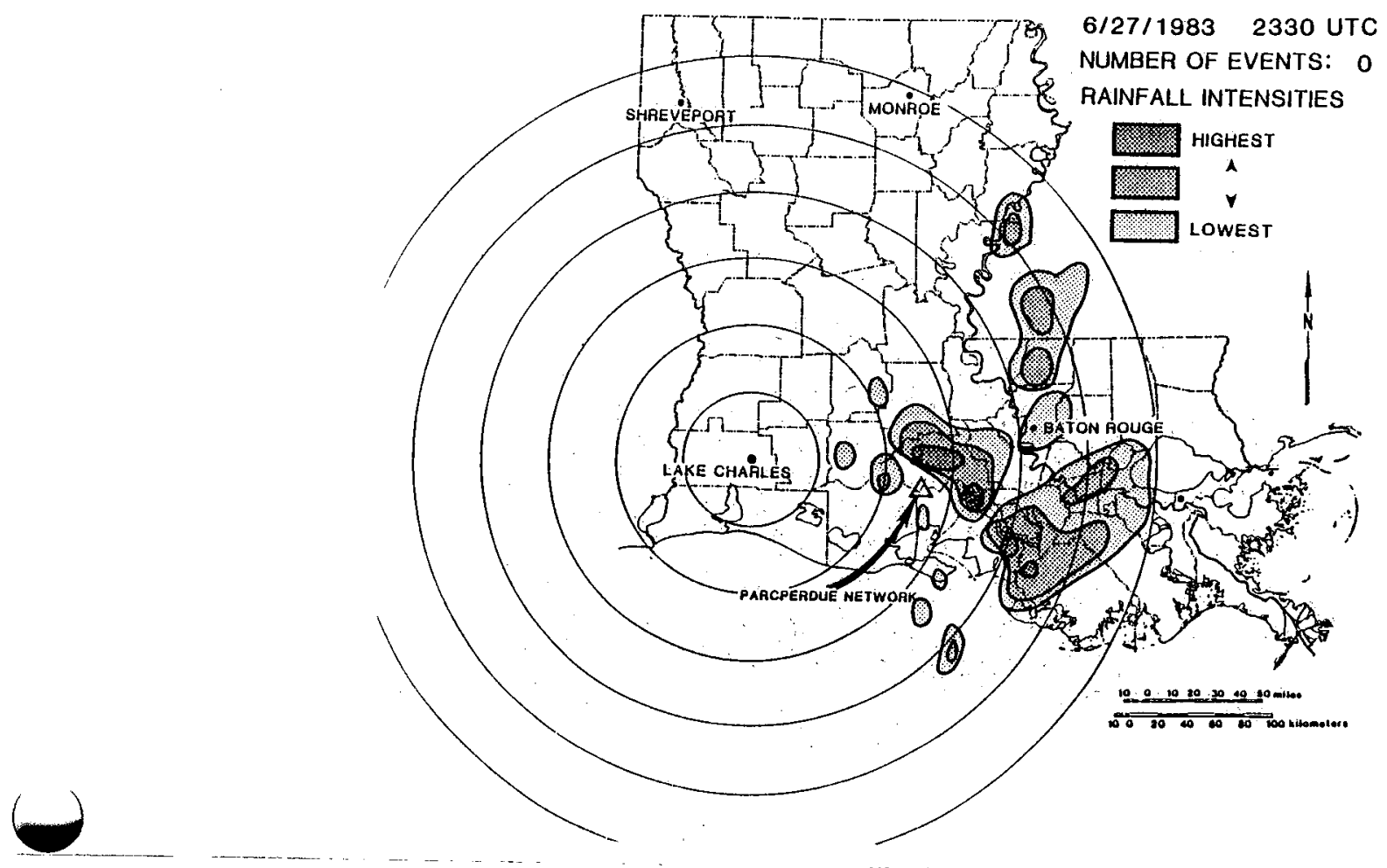

FIGURE 10. Lake Charles radar summary chart, 27 June 1983, 2330 UTC. 


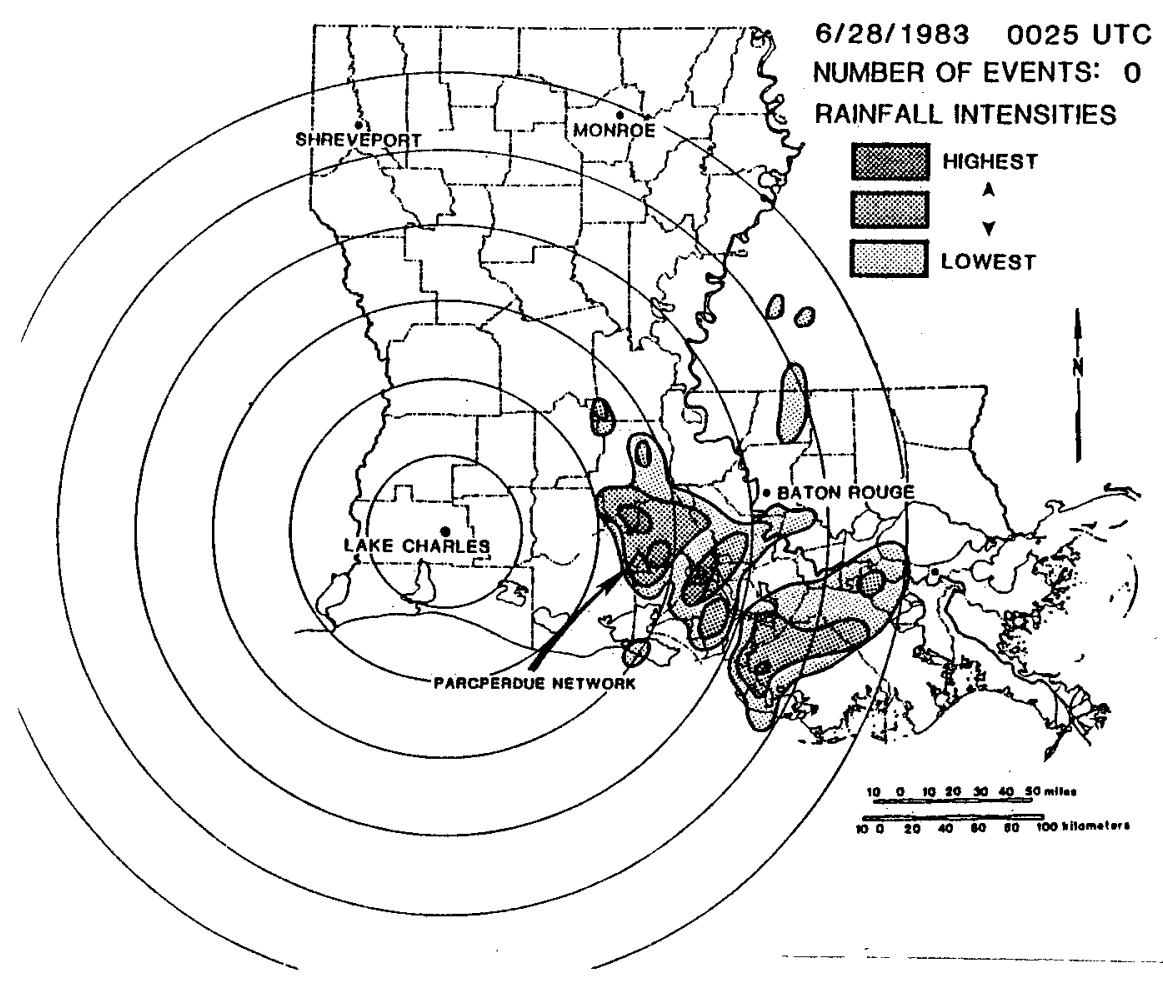

FIGURE 11. Lake Charles radar summary chart, 28 June 1983, 0025 UTC.

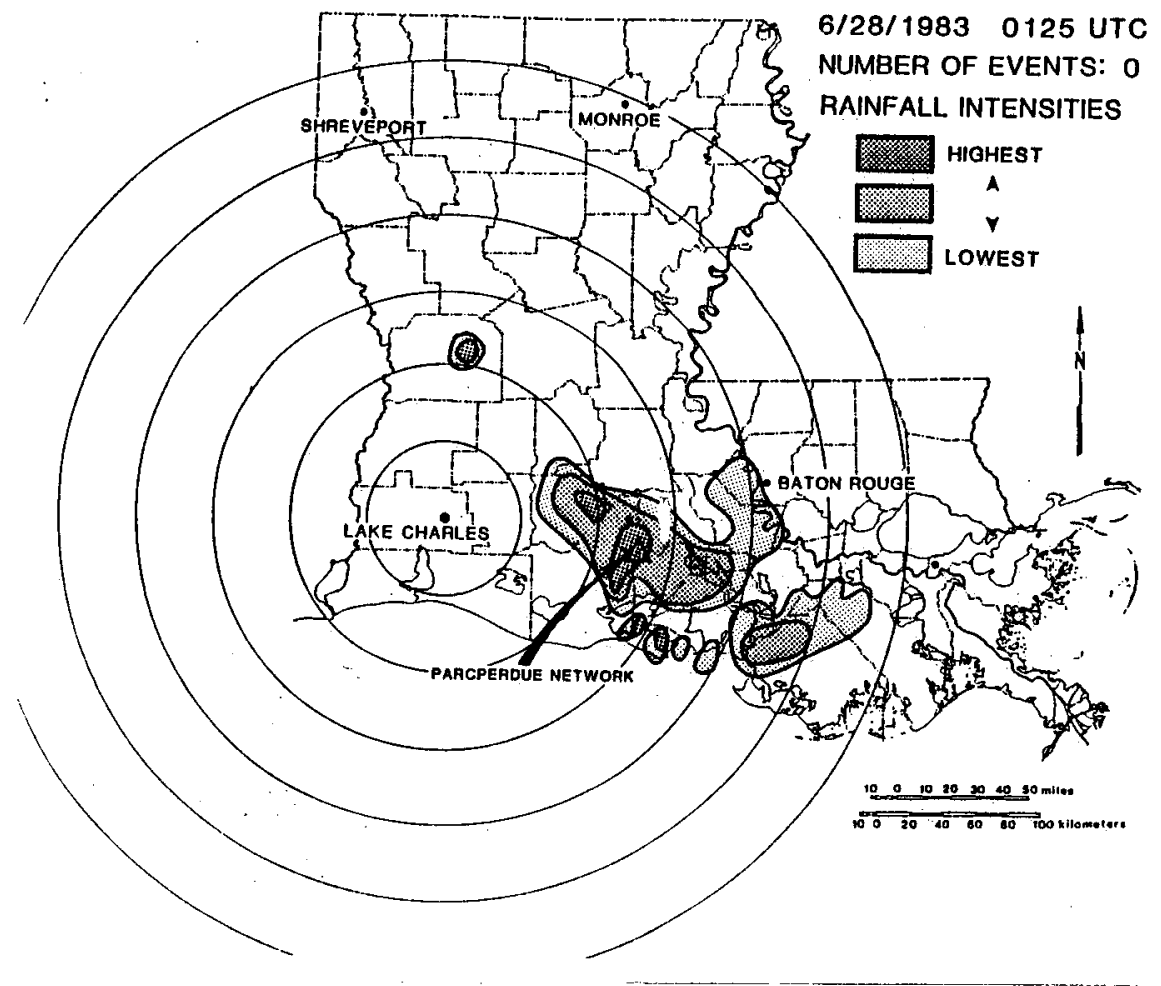

FIGURE 12. Lake Charles radar summary chart, 28 June 1983, 0125 UTC. 


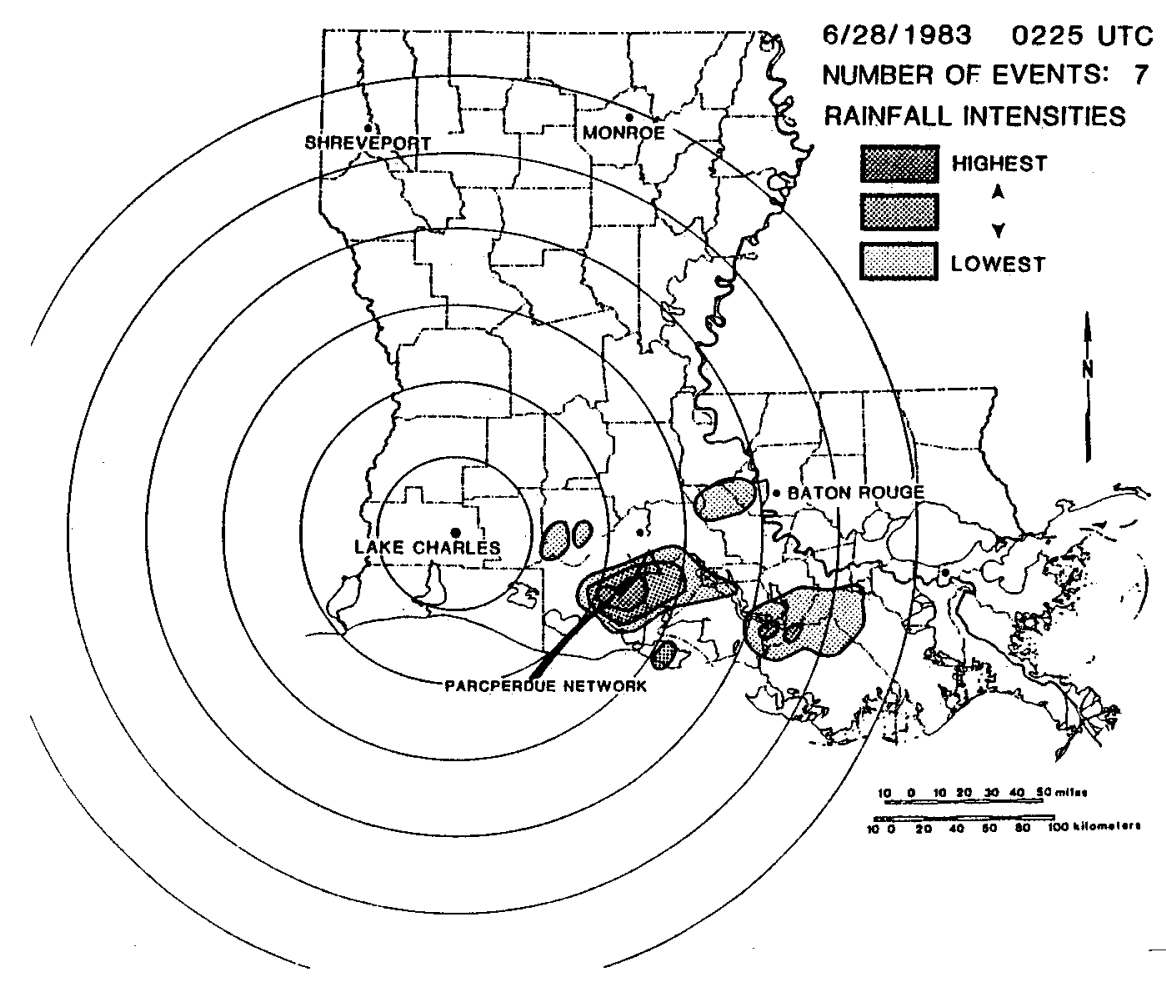

FIGURE 13. Lake Charles radar summary chart, 28 June 1983, 0225 UTC.

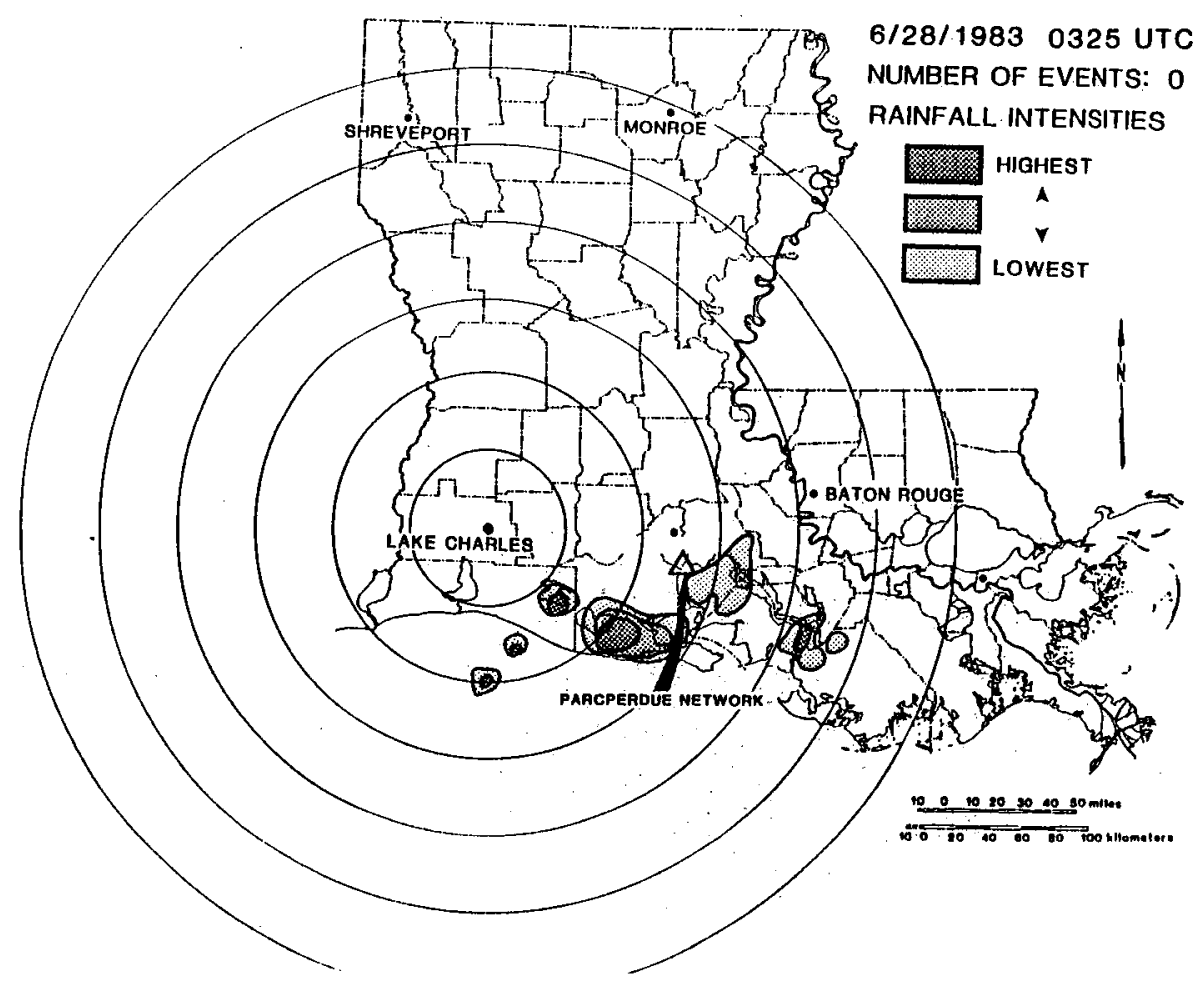

FIGURE 14. Lake Charles radar summary chart, 28 June 1983, 0325 UTC. 


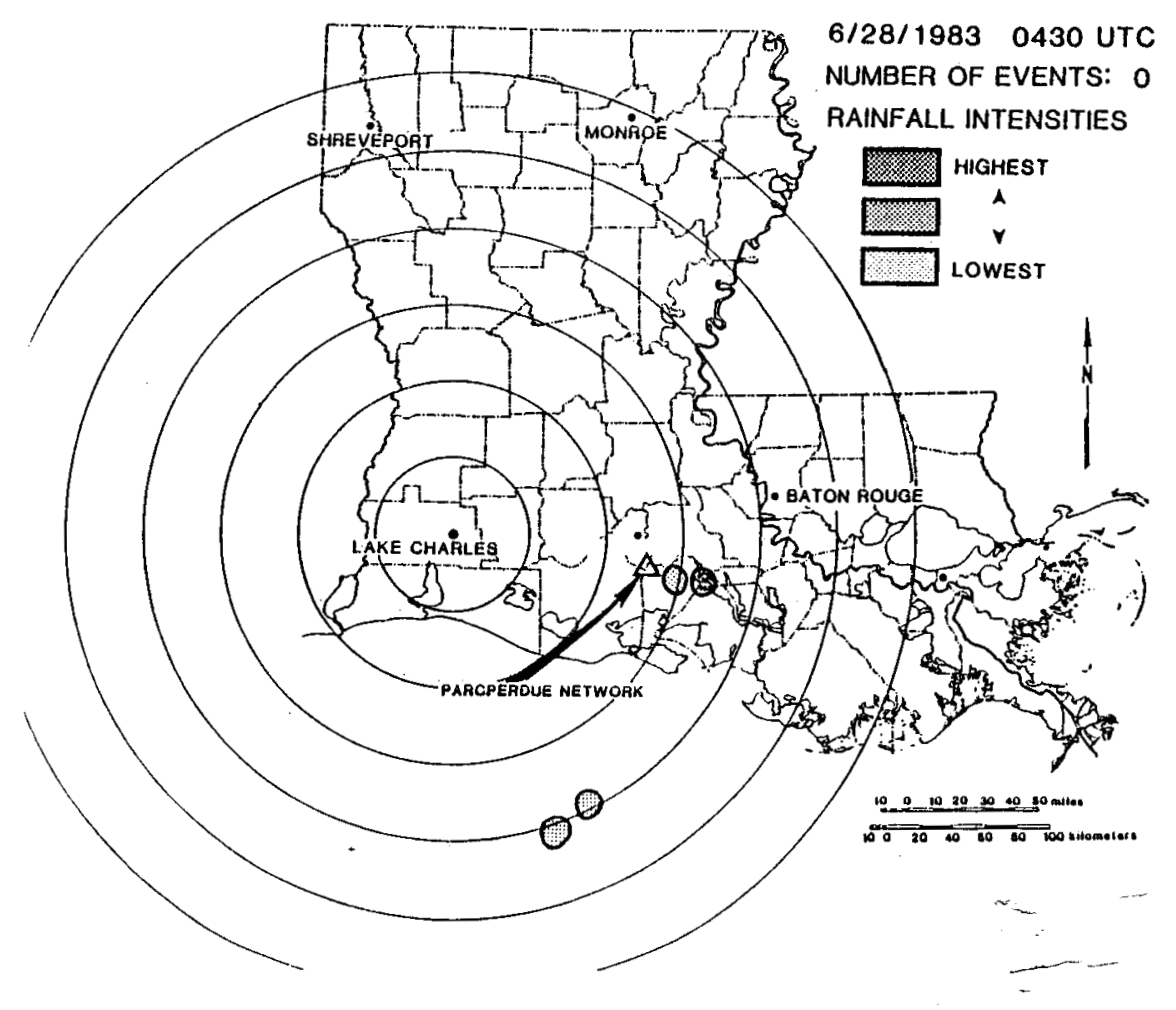

FIGURE 15. Lake Charles radar summary chart, 28 June 1983, 0430 UTC. 


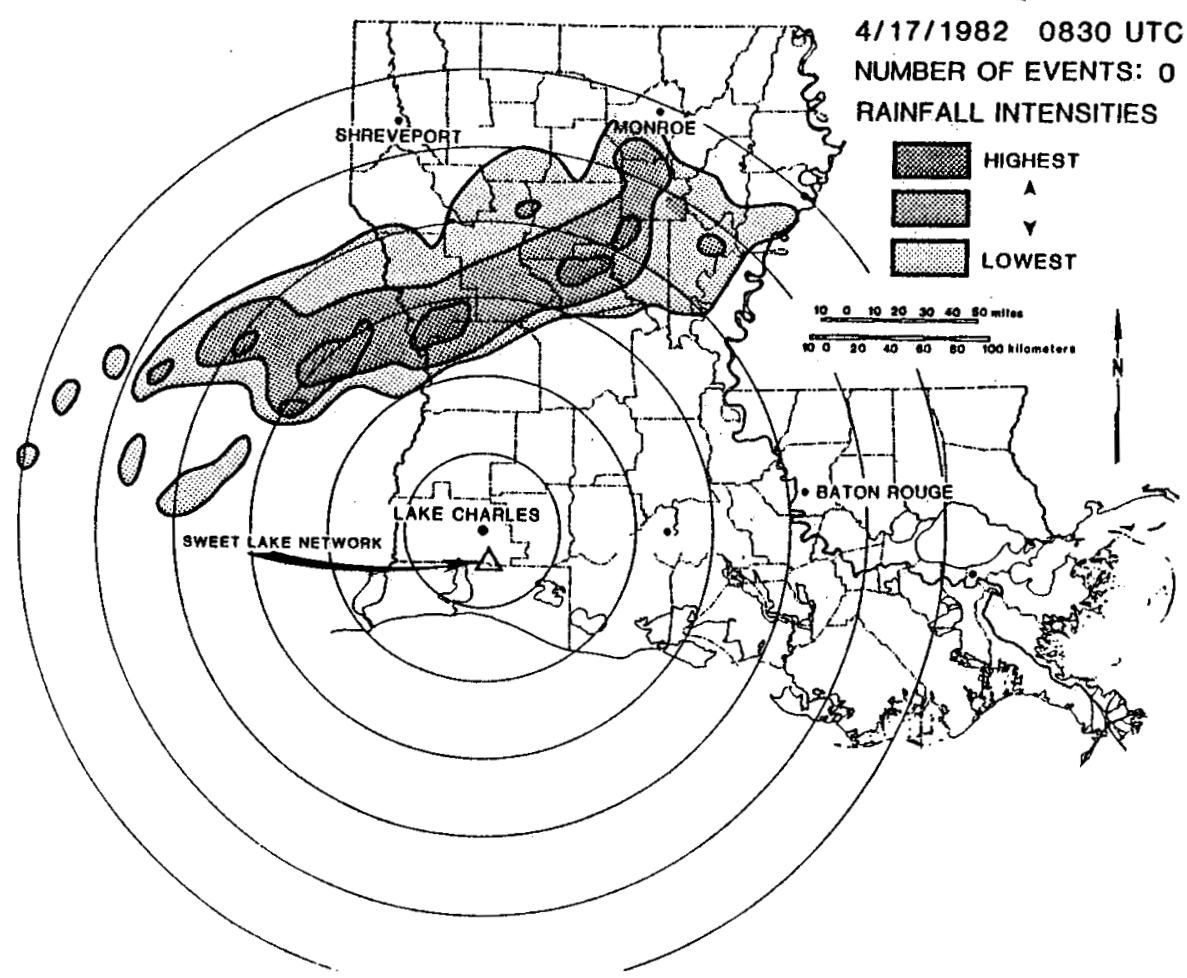

FIGURE 16. Lake Charles radar summary chart, 17 April 1982, 0830 UTC.

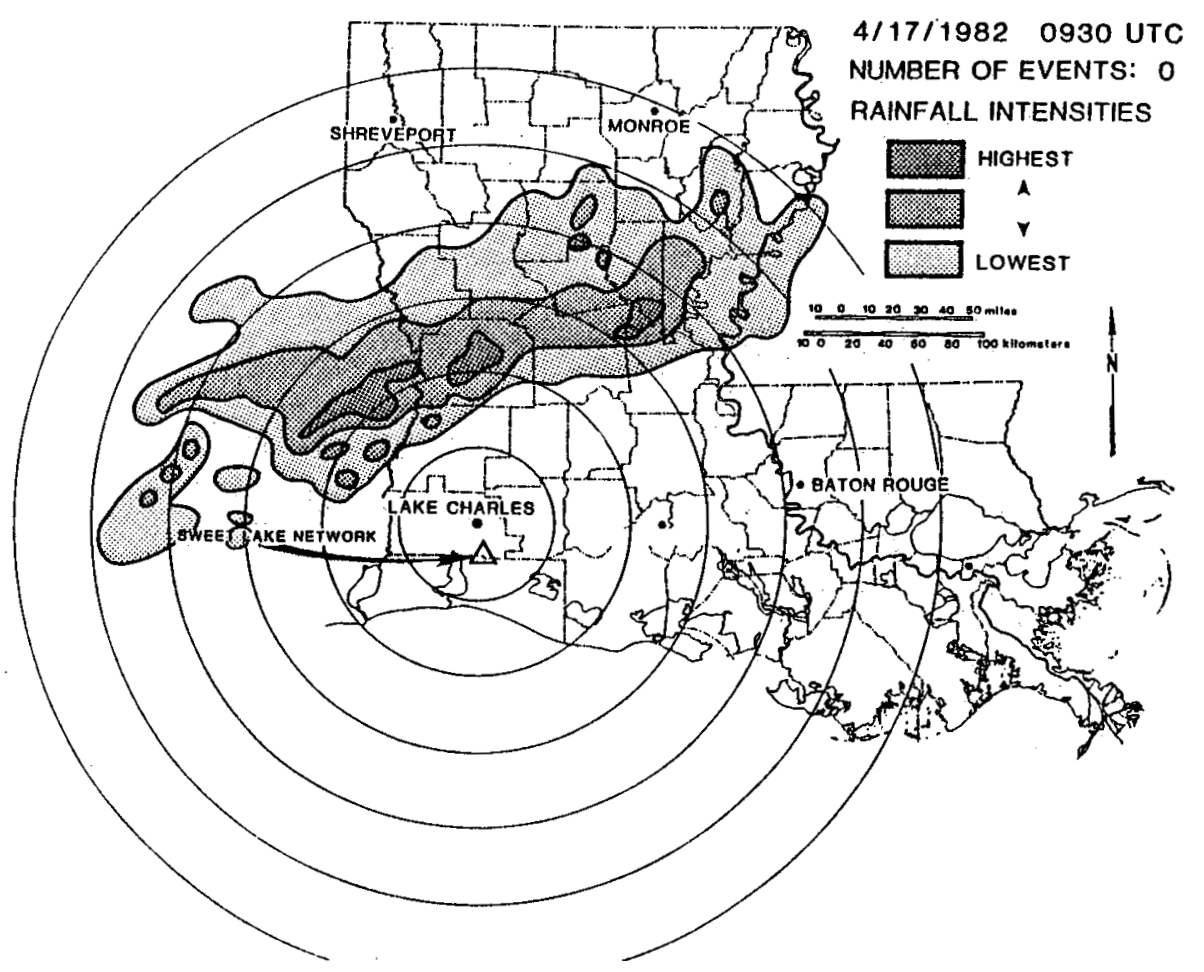

FIGURE 17. Lake Charles radar summary chart, 17 April 1982, 0930 UTC. 


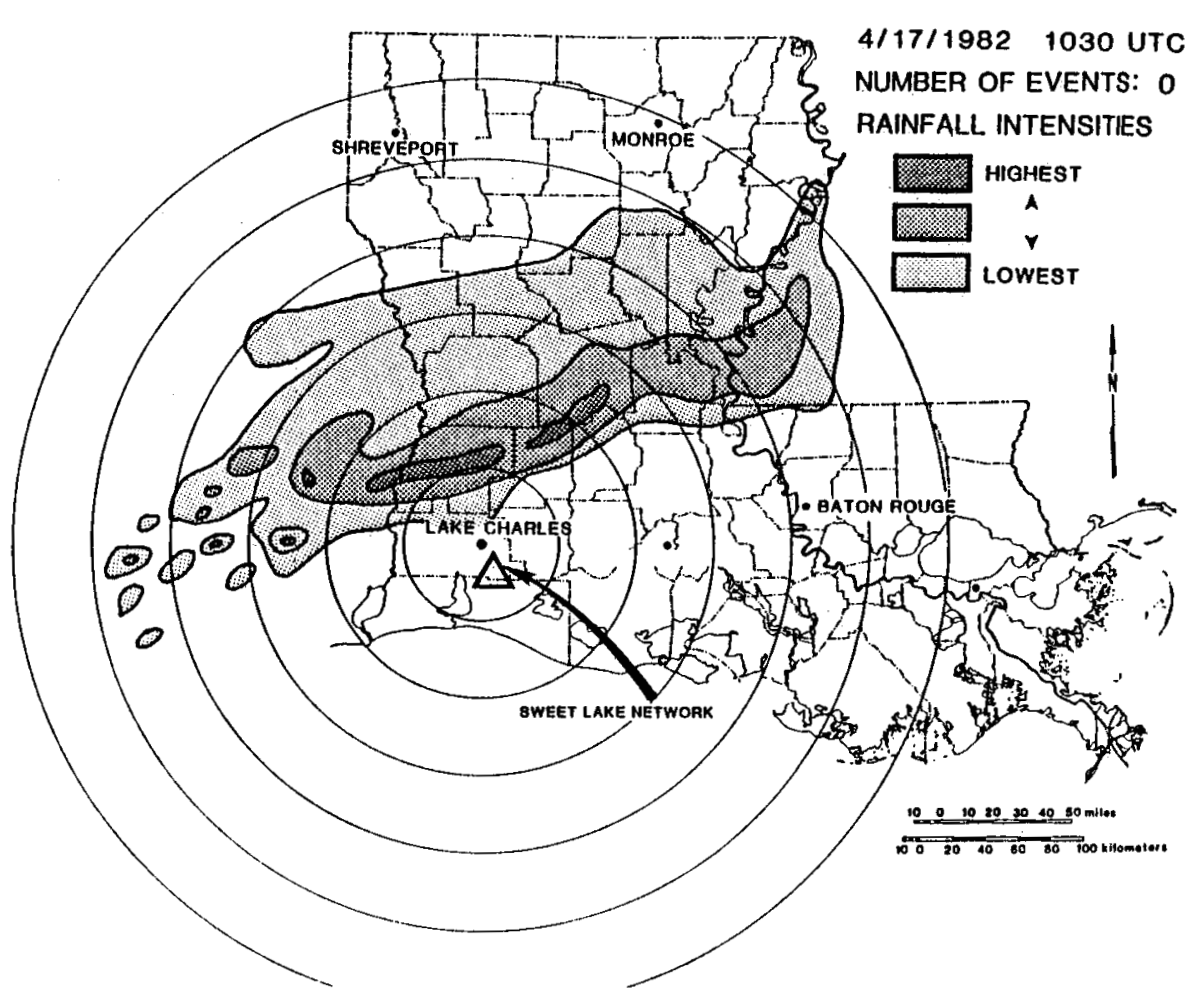

FIGURE 18. Lake Charles radar summary chart, 17 April 1982, 1030 UTC.

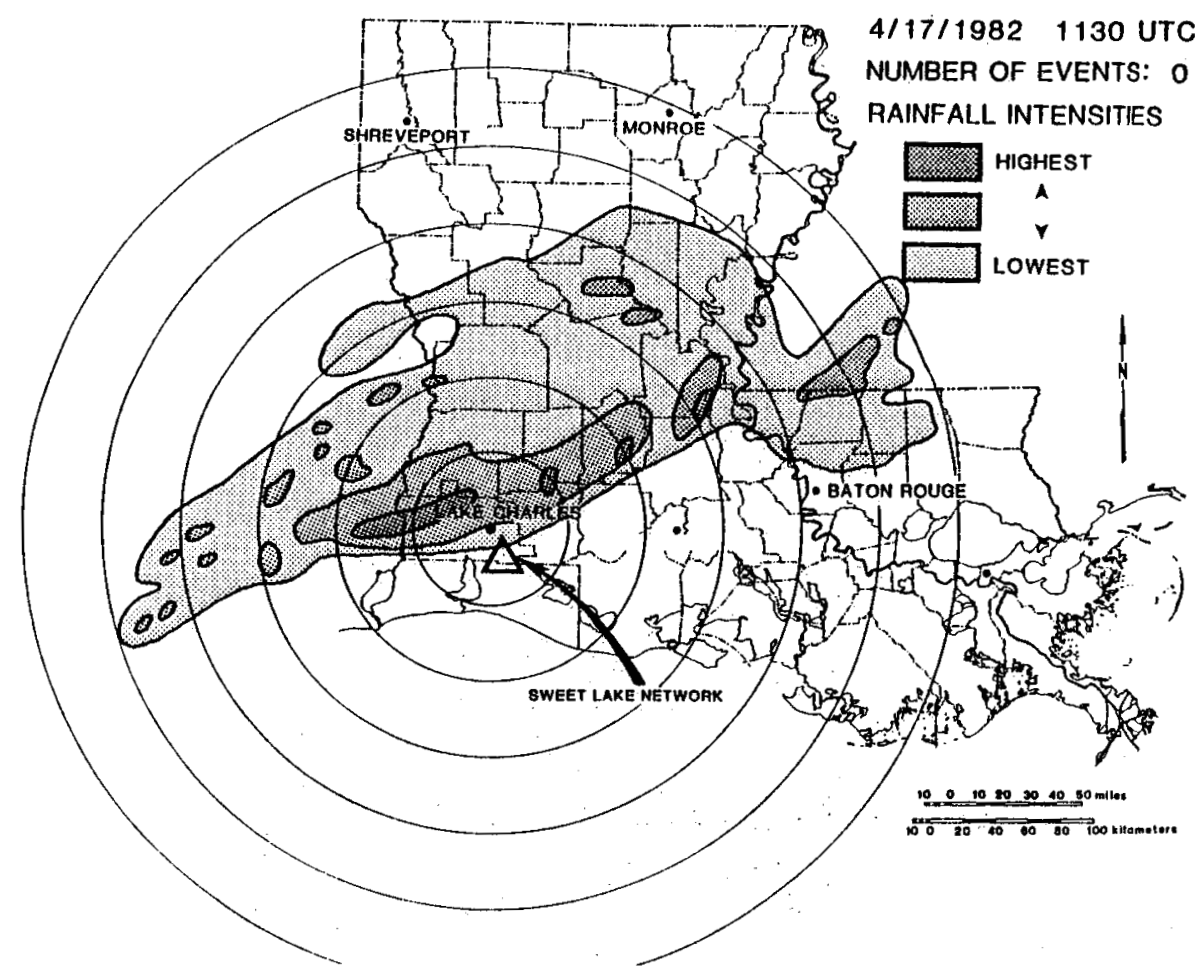

FIGURE 19. Lake Charles radar summary chart, 17 April 1982, 1130 UTC. 


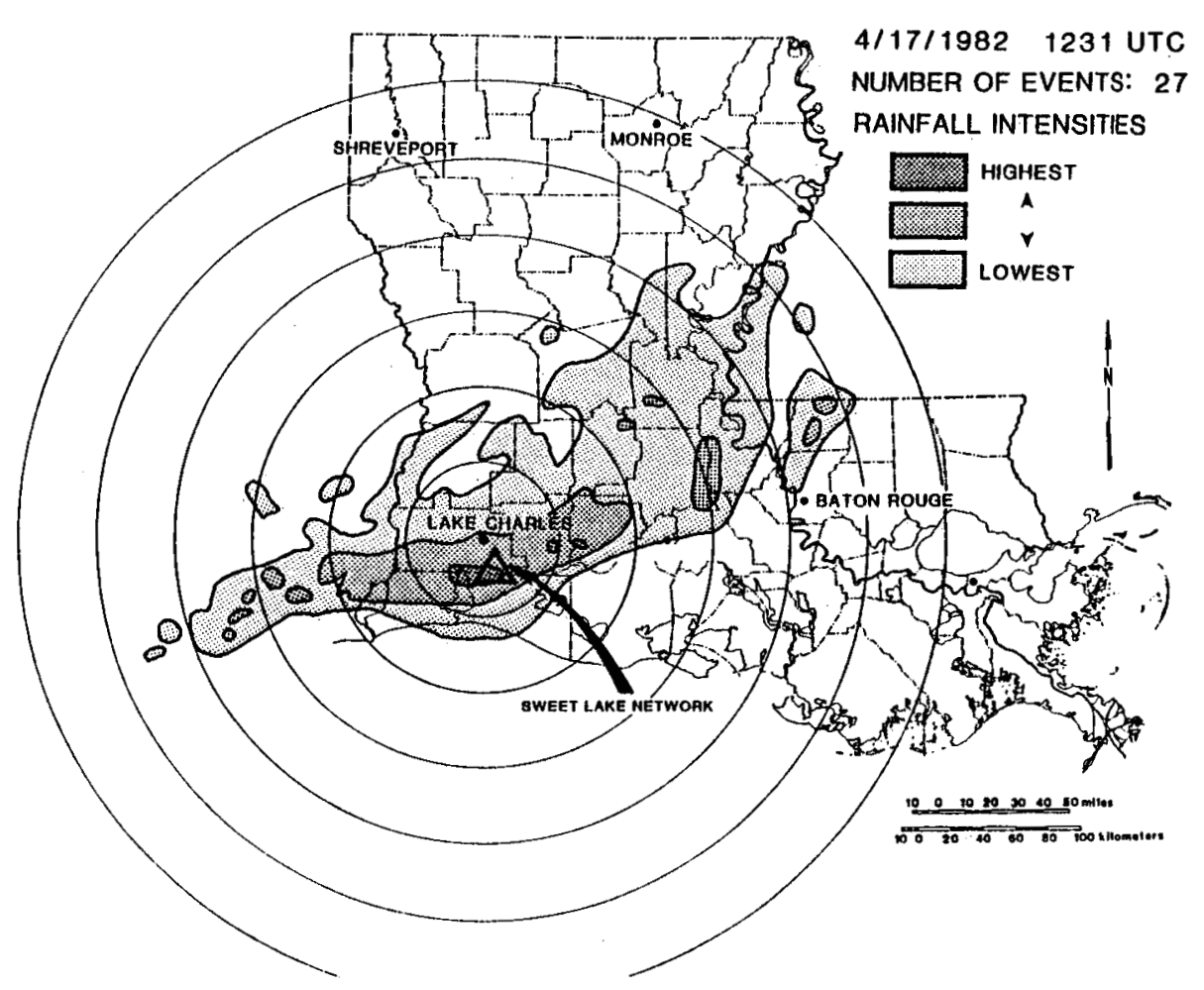

FIGURE 20. Lake Charles radar summary chart, 17 April 1982, 1231 UTC.

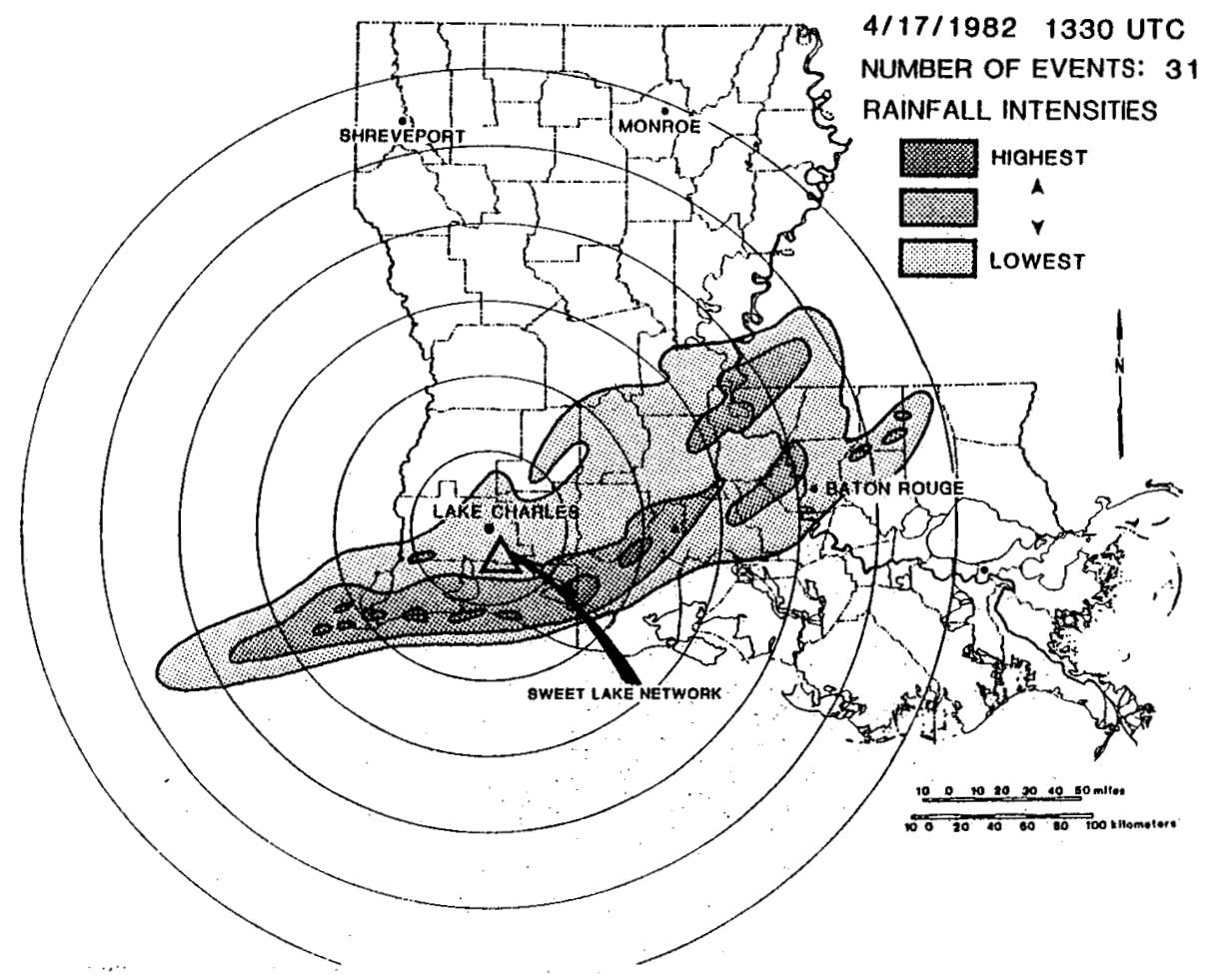

FIGURE 21. Lake Charles radar summary chart, 17 April 1982, 1330 UTC. 


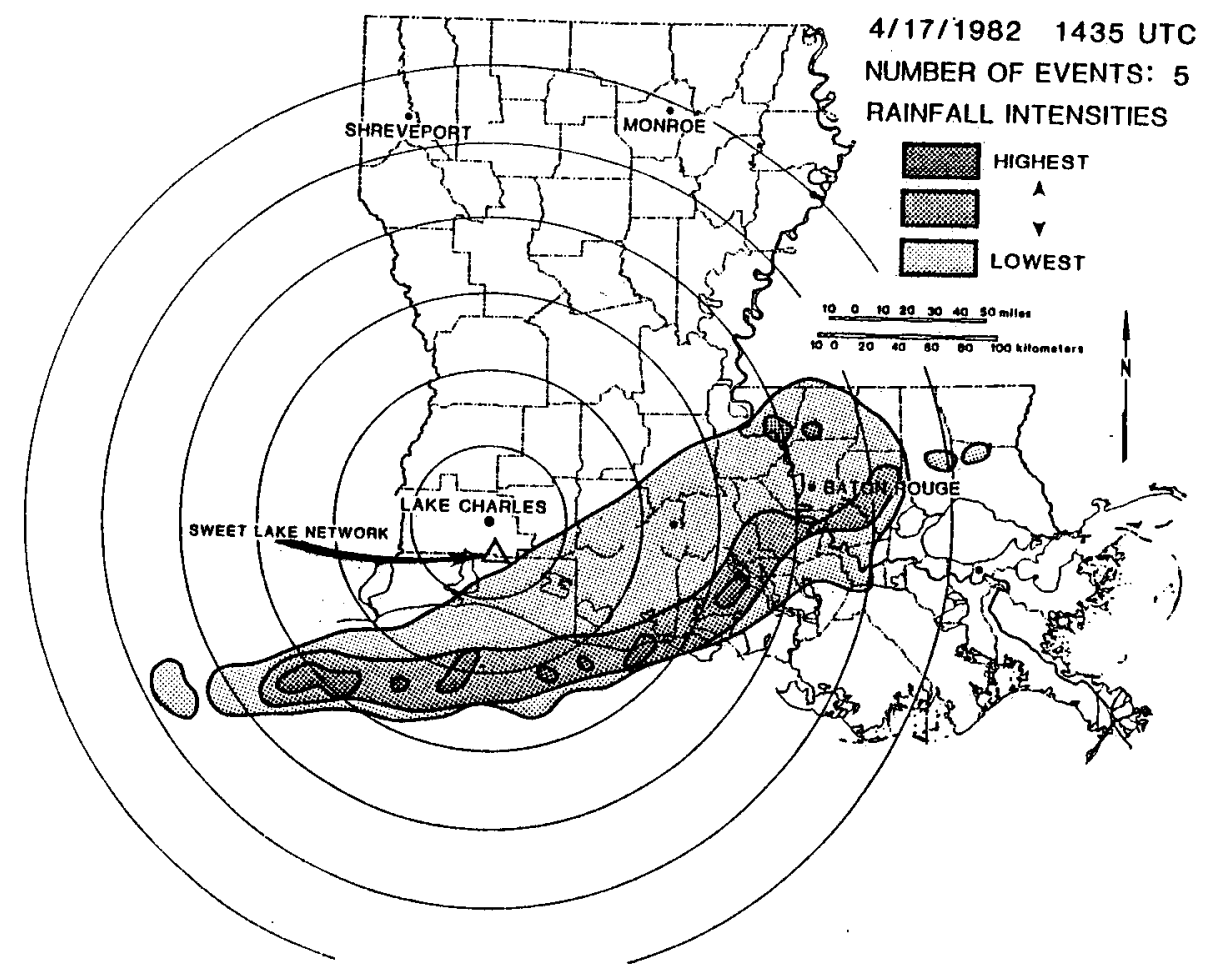

FIGURE 22. Lake Charles radar summary chart, 17 April 1982, 1435 UTC.

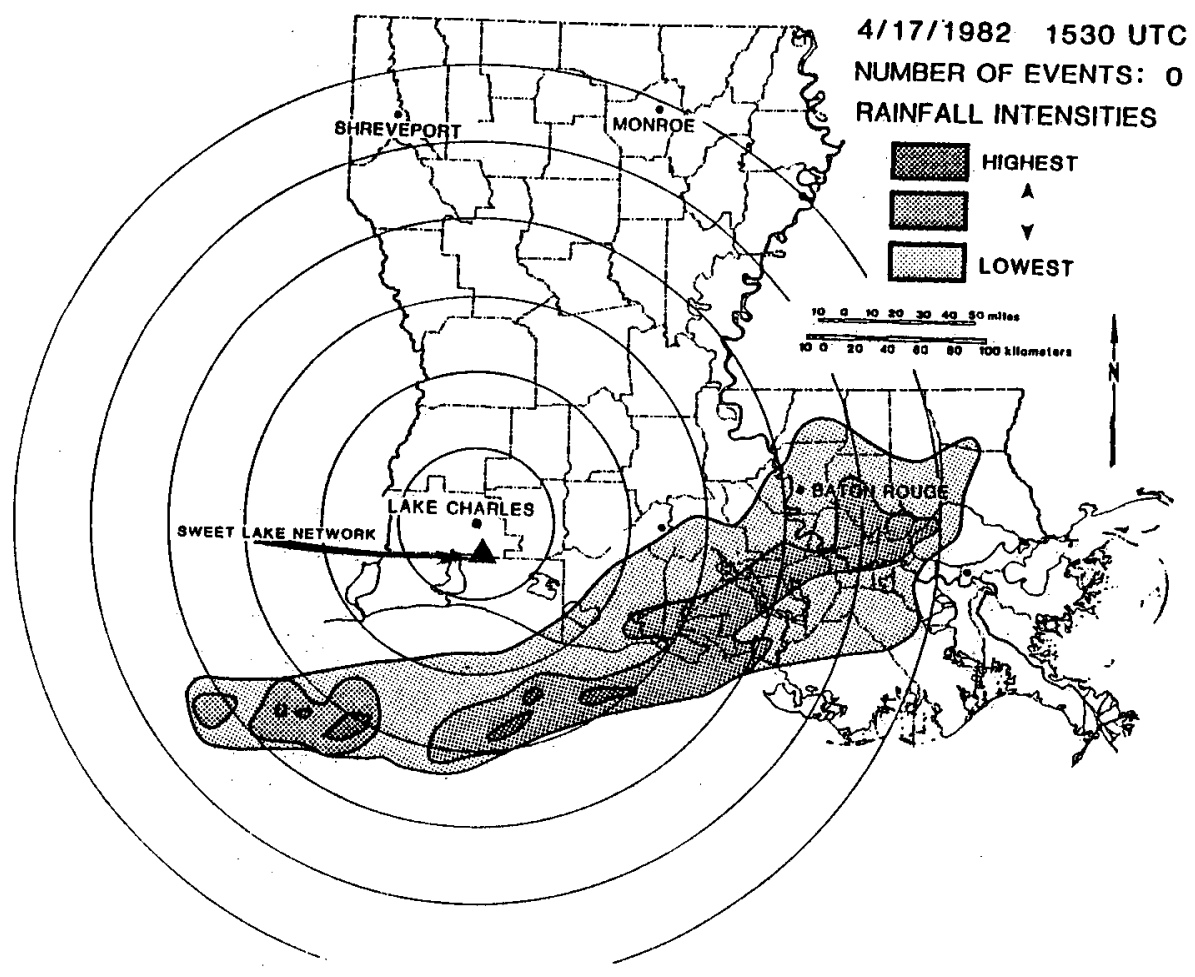

FIGURE 23. Lake Charles radar summary chart, 17 April 1982, 1530 UTC. 


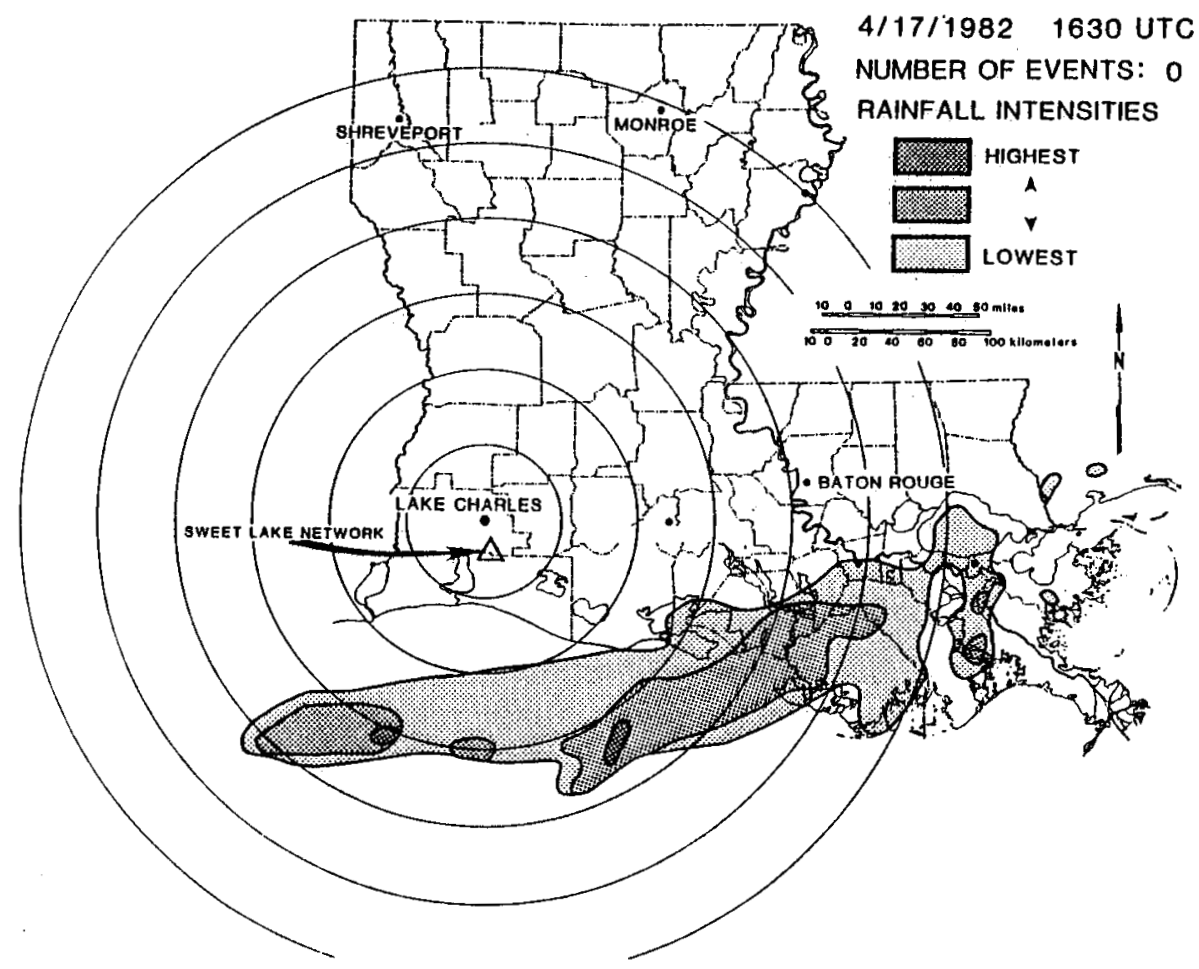

FIGURE 24. Lake Charles radar summary chart, 17 Apri1 1982, 1630 UTC.

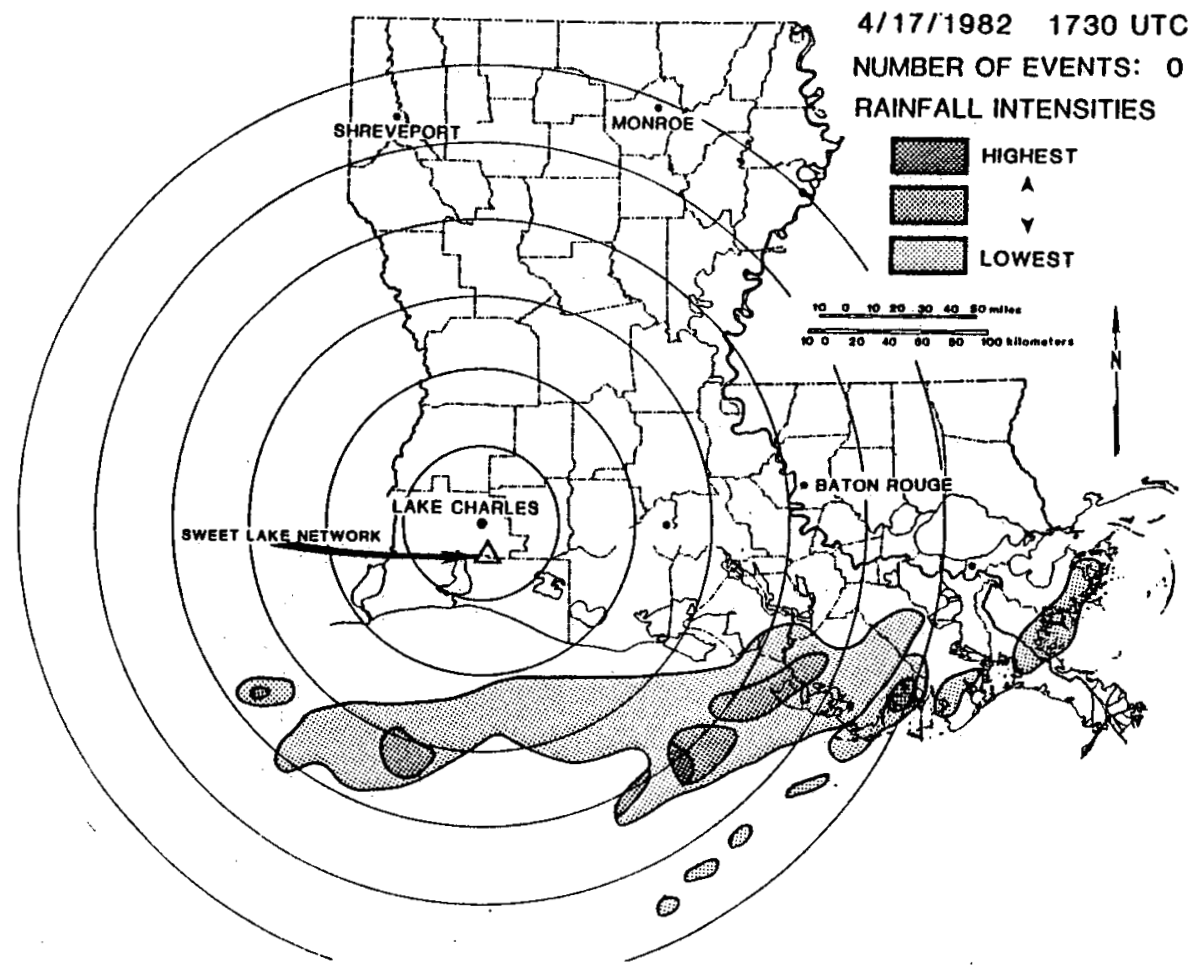

FIGURE 25. Lake Charles radar summary chart, 17 April 1982, 1730 UTC. 


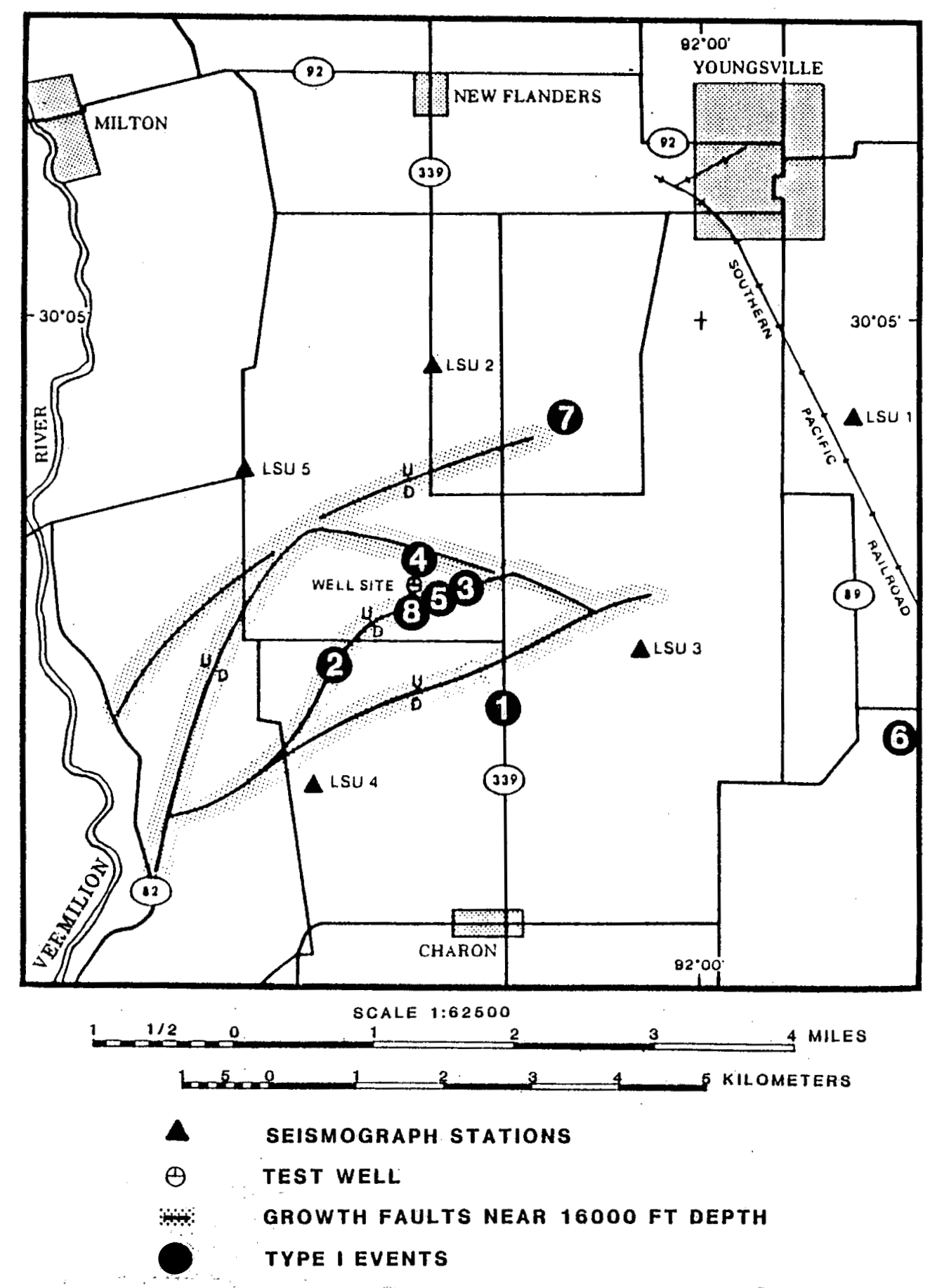

FIGURE 26. Locations of type I events, Parcperdue. 


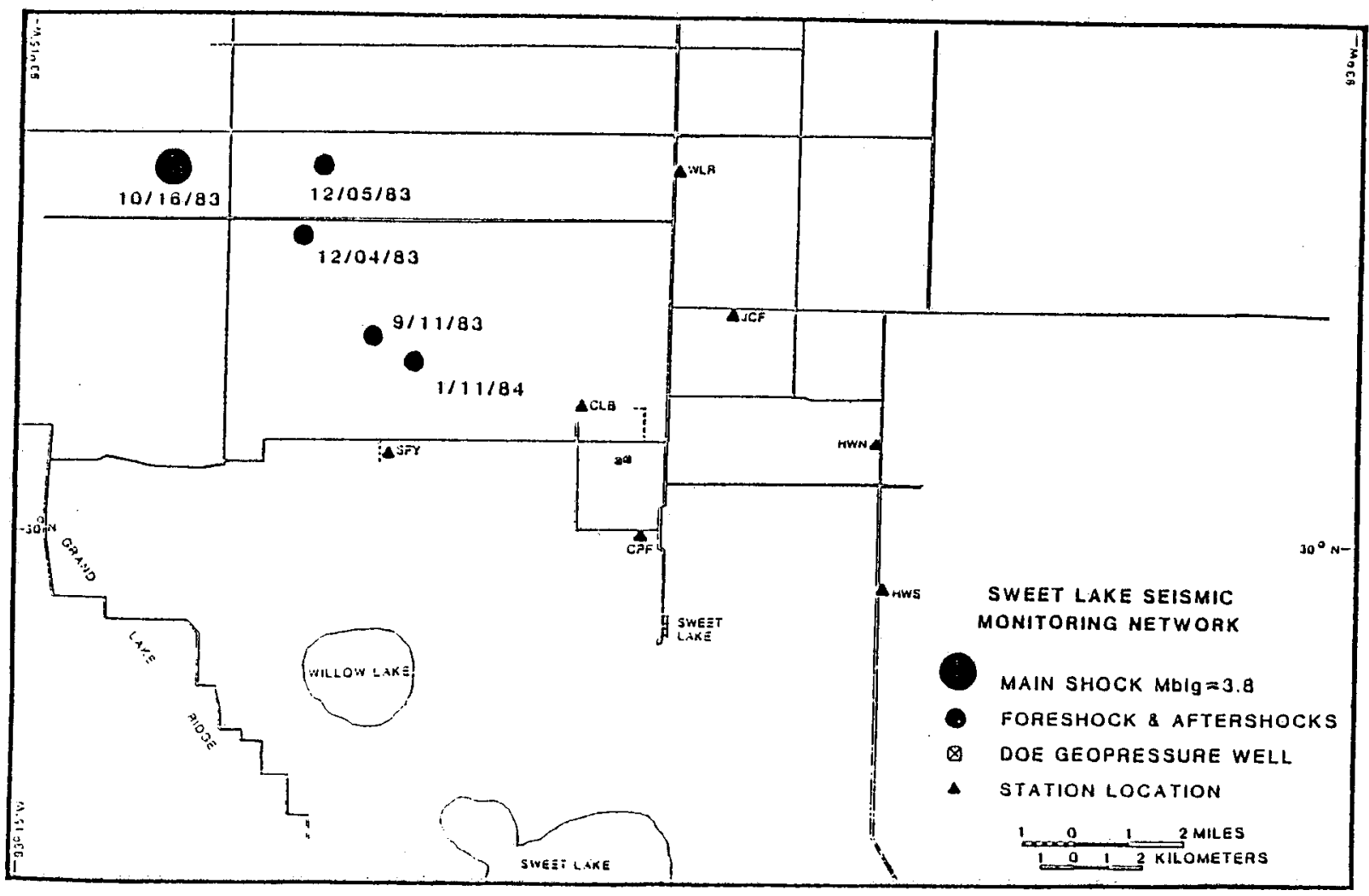

FIGURE 27. Locations of type I events, Sweet Lake. 


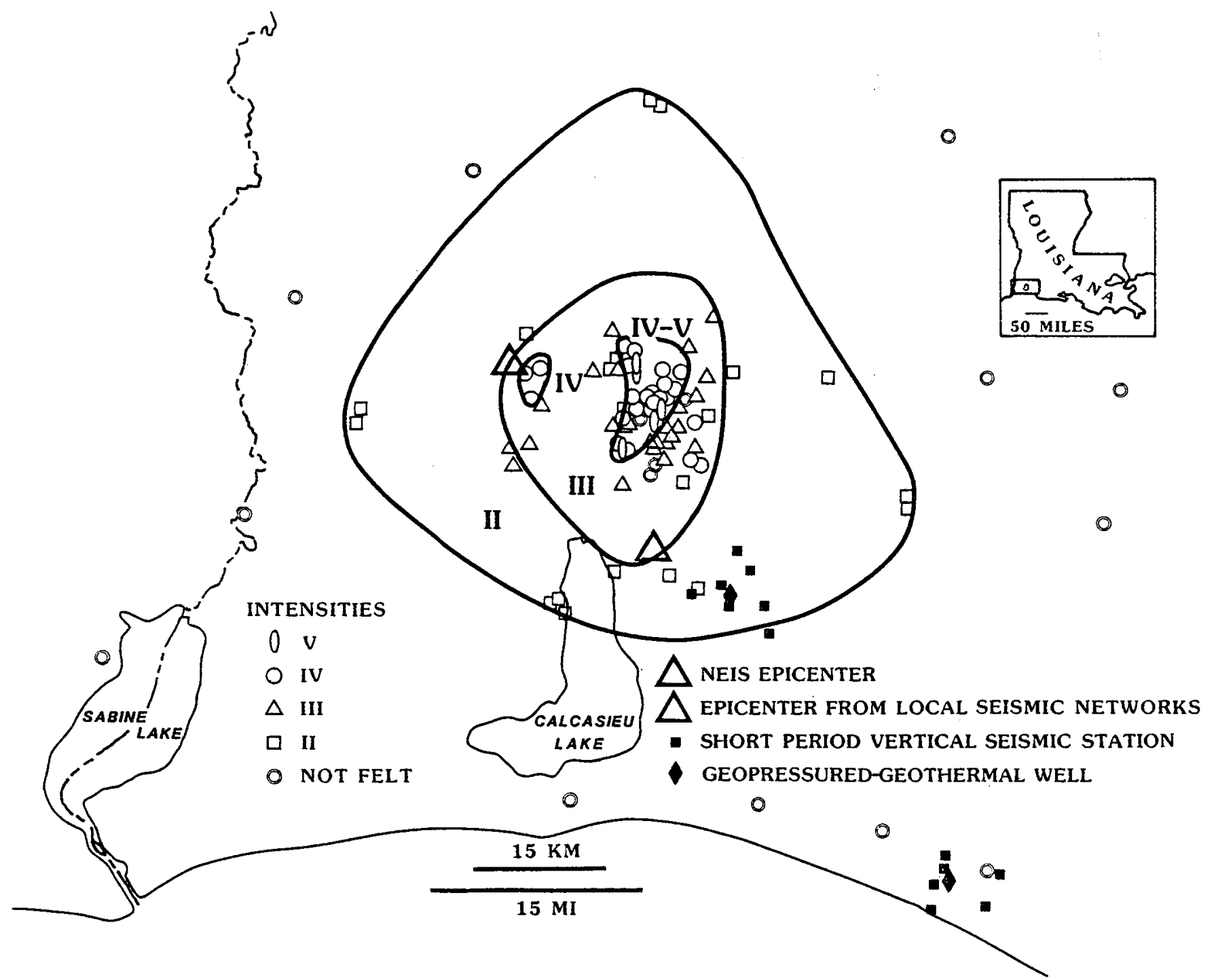

FIGURE 28. Isoseismal map, Lake Charles earthquake, 16 October 1983, magnitude 3.8. 
Short article in the 20 October 1983 issue of the Lake Charles American Press and three of the more detailed responses

\section{Data sought on SW La. earthquake}

The Loulsiana Geological Survey office in Baton Rouge is looking for comments Irom persons who experienced any reaction to a small earth tremor that was recorded Sunday In the area south of Lake Charlea.

The tremor was registered at 2:40 p.m. Sunday about eight miles south of McNeese State Universily.

Donald . Stevenson of the Baton Rouge office asked residents of the area south of Lake Charles to answer the following ques tions "yes" or "no" and to mail the re. sponses to: Loulslana Geologlcal Survey, P.O. Box G, Balon Rouge, La. 70893, marked to Stevenson's attention.

- Did you feelthe tremor?

Yes......No.....

- Were you inside a building?

Yes......No.....

- Did it Irighten anyone?

Yes............

- Any rattling of doors or windows?

Yes......No.....

- Did any objects swing Inside the bullding?

Yes......No.....

- Were there any overturned objects?

Yes......No.....

- Any visible damage? If so, explain;

Yes......No.....

- Give your locatlon (hIghway or streel number) or general location with respect to Lake Charles). 